\title{
Phosphoric Acid Fuel Cells
}

\section{Test and Evaluation}

Robert J. Unger, Scott Kenner, Michael J. Binder, and

October 2004

\section{Franklin H. Holcomb}

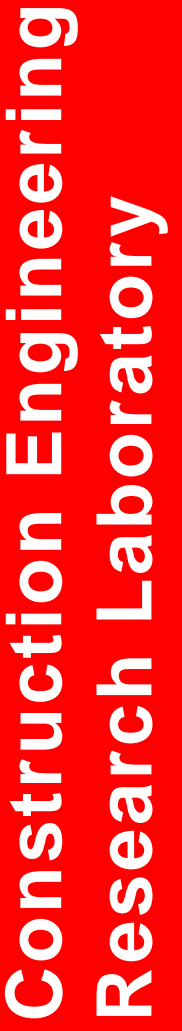

$3 / 21$

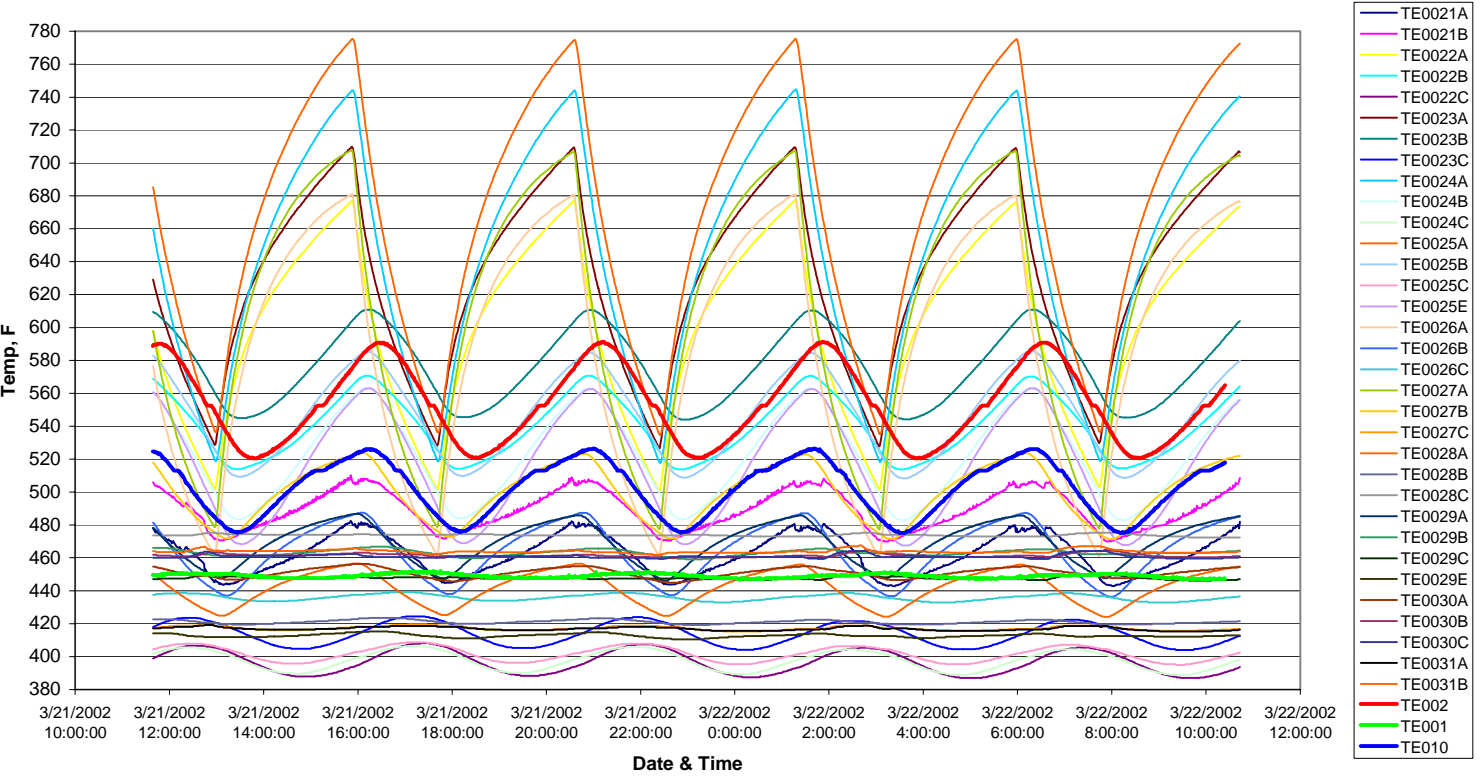

Fuel cells HDS temperature cycling. 


\section{Phosphoric Acid Fuel Cells: Test and Evaluation}

Michael J. Binder and Franklin H. Holcomb

Construction Engineering Research Laboratory

PO Box 9005

Champaign, IL 61826-9005

Robert J. Unger and Scott Kenner

Concurrent Technologies Corporation (CTC)

100 CTC Drive

Johnstown, PA 15904

Final Report

Approved for public release; distribution is unlimited.

Prepared for U.S. Army Corps of Engineers

Washington, DC 20314-1000\# 


\begin{abstract}
Fuel cell power plants can provide improvements in energy conservation and reduced environmental impacts for many DOD applications. Currently, the U.S. Army Engineer Research and Development Center, Construction Engineering Research Laboratory (ERDC/CERL) Fuel Cell Technology Program facilitates the development of Fuel Cell Technology. This work provided testing and evaluations of fuel cells in support of life-cycle-cost reduction and performance improvement goals. This program also undertook to provide the capability for independent design assessments of alternative technology fuel cell system configurations and components to achieve lower life cycle cost either through reduced capital cost, reduced operation and maintenance (O\&M) costs, or increased performance and reliability.
\end{abstract}

DISCLAIMER: The contents of this report are not to be used for advertising, publication, or promotional purposes. Citation of trade names does not constitute an official endorsement or approval of the use of such commercial products. All product names and trademarks cited are the property of their respective owners. The findings of this report are not to be construed as an official Department of the Army position unless so designated by other authorized documents.

DESTROY THIS REPORT WHEN IT IS NO LONGER NEEDED. DO NOT RETURN IT TO THE ORIGINATOR. 


\section{Contents}

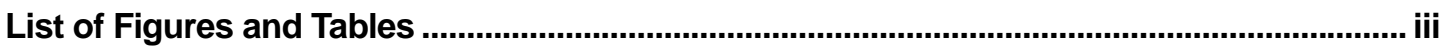

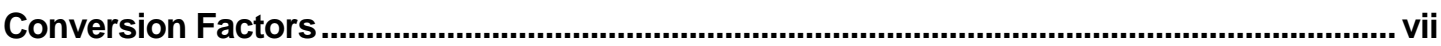

Preface

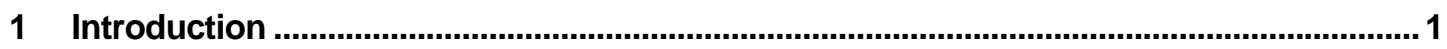

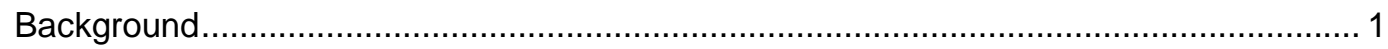

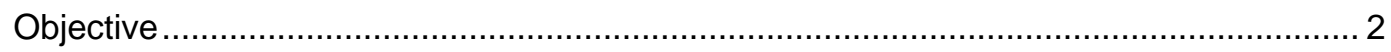

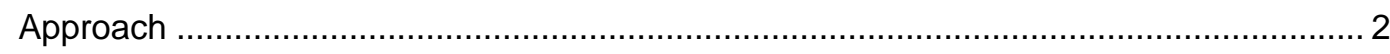

Scope

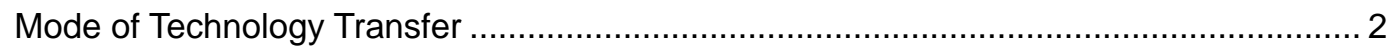

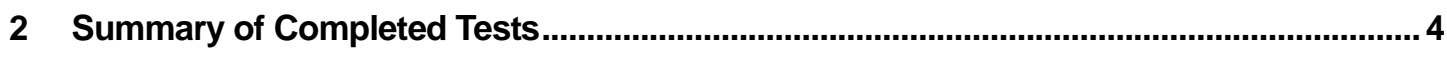

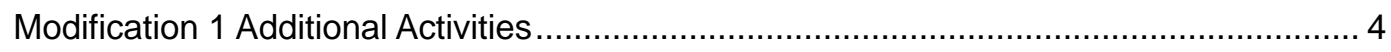

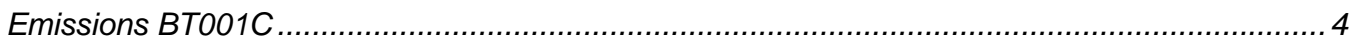

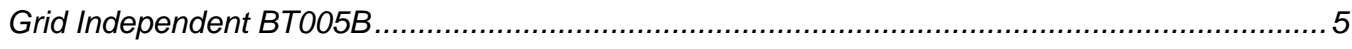

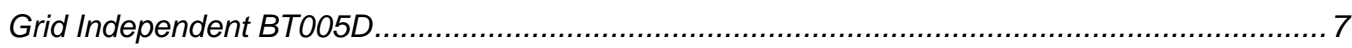

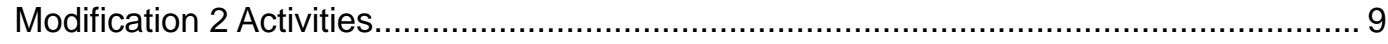

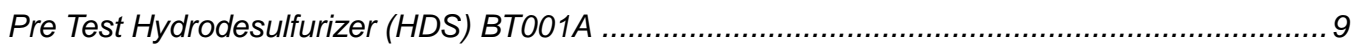

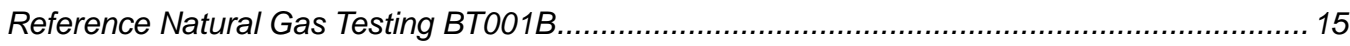

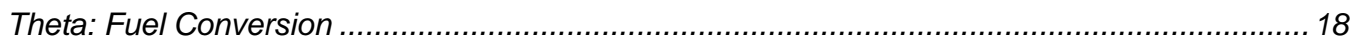

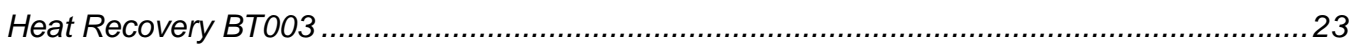

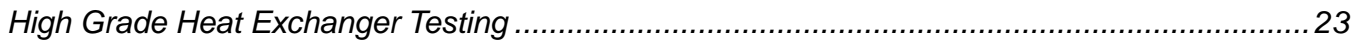

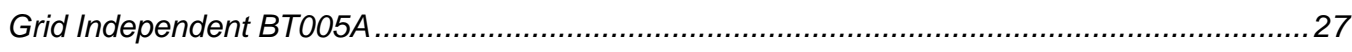

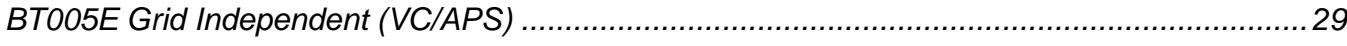

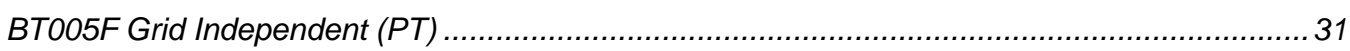

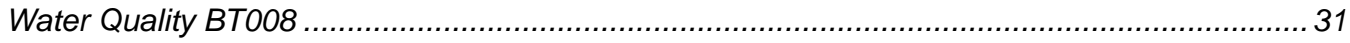

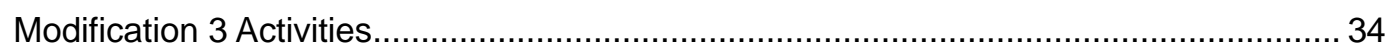

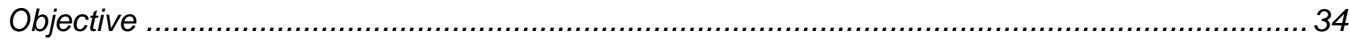

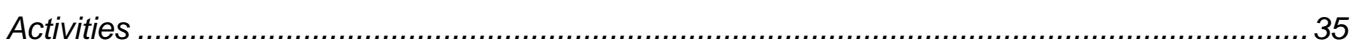

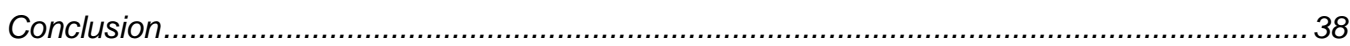

3 Summary

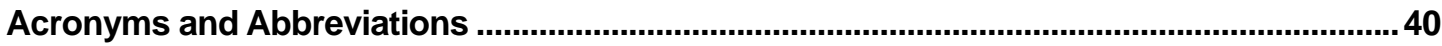


Appendix A: Initial Report Task 211 (28 December 2000) ….................................................. 41

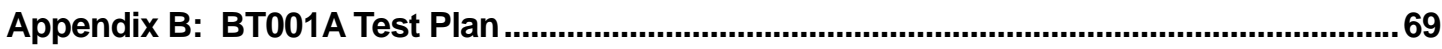

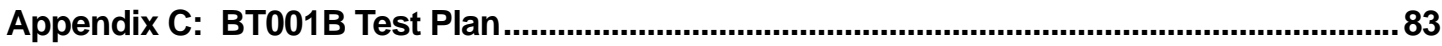

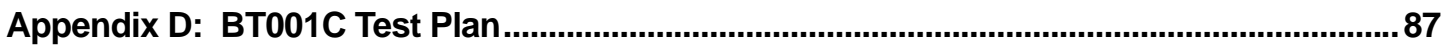

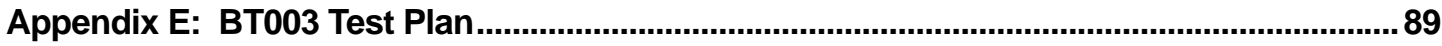

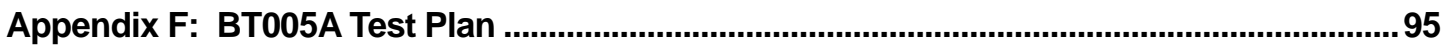

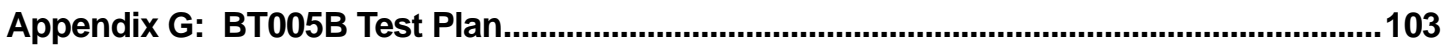

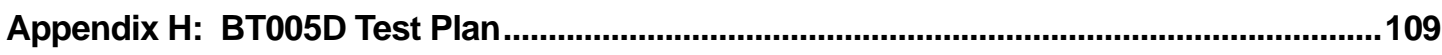

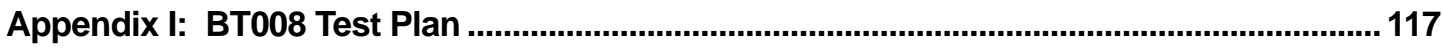

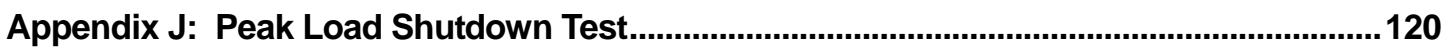

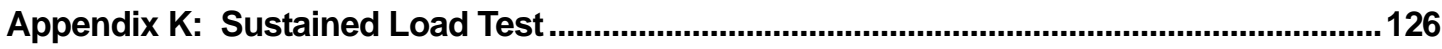

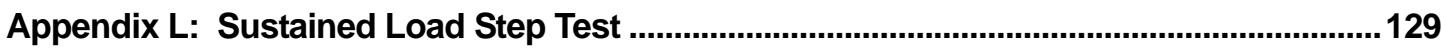

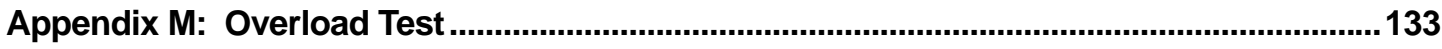

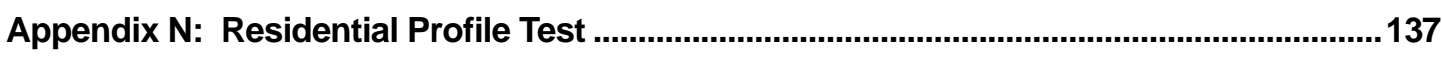

Appendix O: Residential Profile Test with Respect to Temperature and Humidity.............145

Appendix P: Combined Heat and Power Test.................................................................. 149

Appendix Q: 15 Amp Circuit Breaker Overload Test .....................................................152

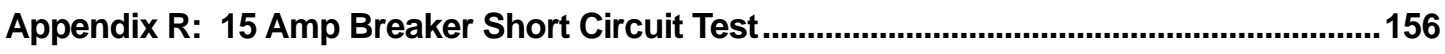

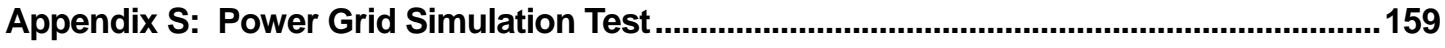

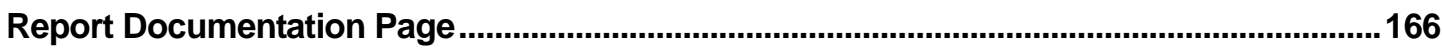




\section{List of Figures and Tables}

\section{Figures}

1 Overload time plot chart at $220 \mathrm{~kW}$ for 1, 2, 3, 4, and 5-second intervals................. 7

2 Maximum voltage distortion experienced under non-linear load ............................. 8

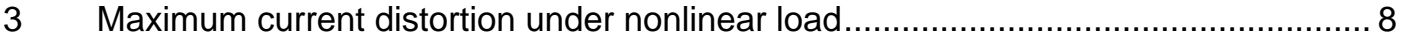

$4 \quad$ UTC fuel cells HDS temperature cycling, BOM configuration............................... 11

5 Improved HDS temperature profile, relocated heaters and control TC.................... 12

$6 \quad$ HDS bed temperature with electronic control and sulfur analysis ........................... 14

$7 \quad$ Fuel Cell Power Plant 9194 stack voltages at $200 \mathrm{~kW}$ power output ........................ 22

$8 \quad$ Fuel Cell Power Plant 9194 sub-stack voltage profile............................................. 22

$9 \quad$ High-grade heat recovery, low vs. high range flow meter ..................................... 24

10 Low-grade heat recovery, flow meter comparison (@ 25 gpm) …........................... 25

11 Available PC25 heat recovery, $200 \mathrm{~kW}$, beginning of life ......................................... 26

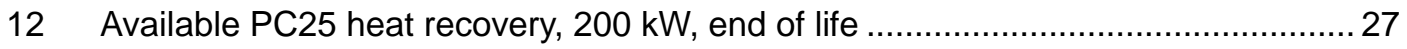

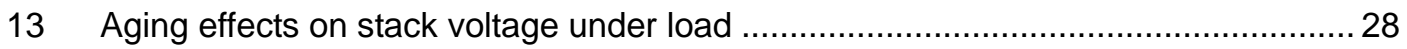

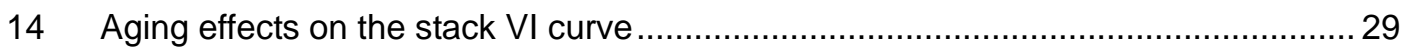

15 Nineteen tube reformer shutdown temperature profile ....................................... 32

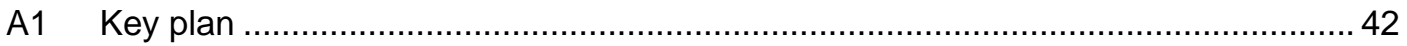

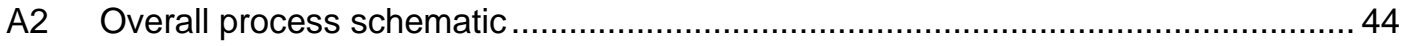

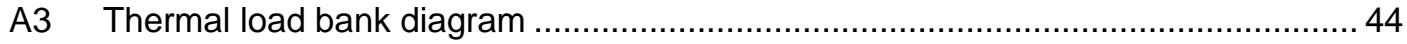

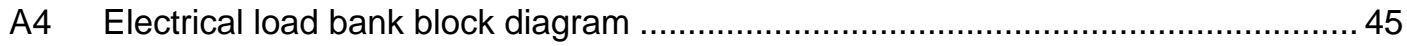

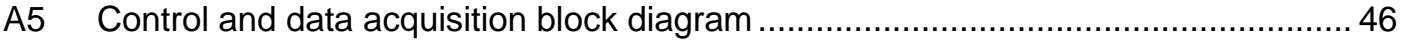

B1 ILS, including heater and thermocouple arrangement ......................................... 73

\section{Tables}

1 Pounds per MW-hr emissions of fuel cell gases ............................................... 5

2 Gas analysis results, gas chromatograph (May 2000)....................................... 18

3 Gas analysis results, gas chromatograph (August 2000) …................................. 19

$4 \quad$ Gas analysis results, field anarad (December 2001) .......................................... 19

$5 \quad$ Gas analysis results, gas chromatograph (January 2002) ................................... 20 
$6 \quad$ Gas analysis results, field anarad (January 2002) ............................................. 21

High grade heat exchanger test conditions..................................................... 24

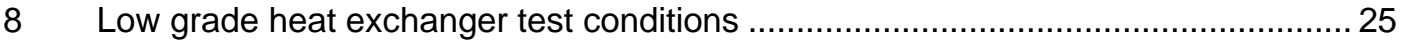

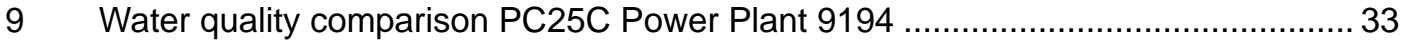

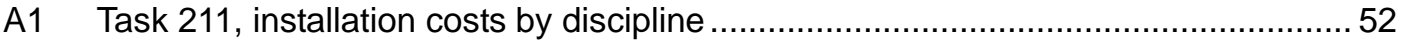

A2 Task 211, installation labor by discipline, ........................................................ 52

A3 Task 211, hex 880 test parameters, water/glycol - high grade in use ..................... 58

A4 Task 211, hex 880 test parameters, water/glycol - high grade not in use ................ 58

B1 BT001A test, miscellaneous data acquisition parameters ..................................... 71

B2 BT001A test, thermocouple data acquisition parameters .................................... 71

B3 BT001A test, radar data acquisition parameters ................................................. 71

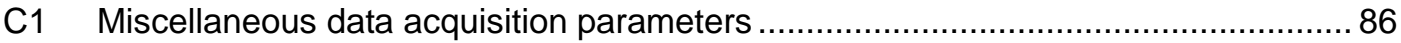

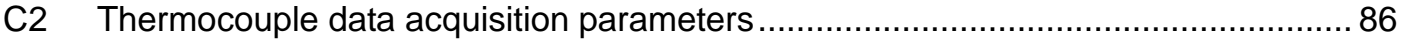

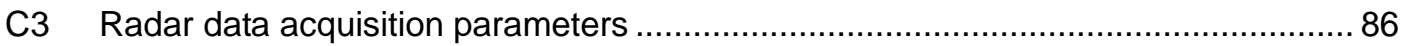

E1 BT003 test, hex 880 test parameters, water/glycol - high grade in use .................. 92

E2 BT003 test, hex 880 test parameters, water/glycol - high grade not in use ............. 94

F1 BT005A test, miscellaneous data acquisition parameters ....................................... 96

F2 BT005A test, ELB data acquisition parameters status ........................................ 96

F3 BT005A test, ELB data acquisition parameters values ...................................... 97

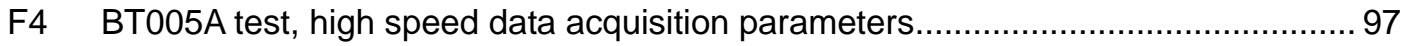

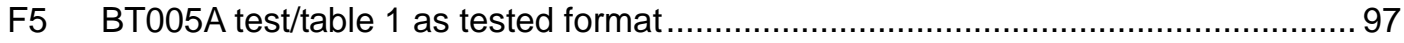

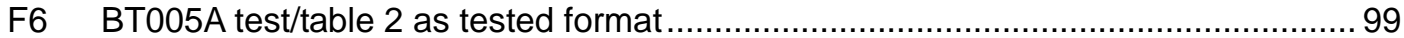

F7 BT005A test/table 3 as tested format .............................................................. 100

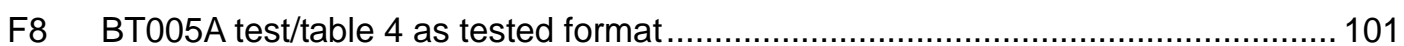

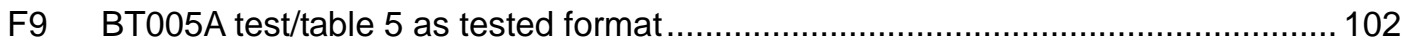

G1 BT005B test, miscellaneous data acquisition parameters .................................... 105

G2 BT005B test, ELB data acquisition parameters status....................................... 106

G3 BT005B test, ELB data acquisition parameters values ....................................... 106

G4 BT005B test, high speed data acquisition parameters …................................. 106

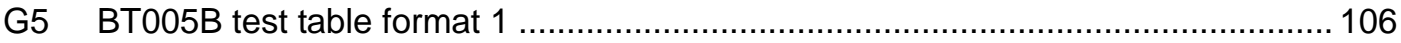

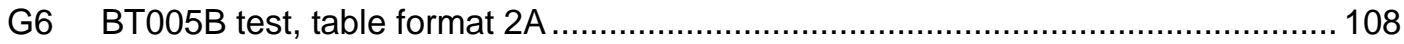

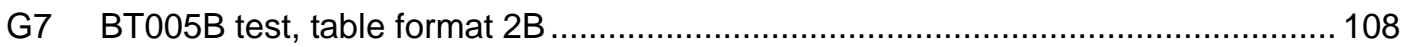

H1 BT005D test, miscellaneous data acquisition parameters .................................. 110

H2 BT005D test, high speed data acquisition parameters ....................................... 110

H3 BT005D test, ELB data acquisition parameters status ....................................111

H4 BT005D test, ELB data acquisition parameters values.....................................111

H5 BT005D test 1, full load resistive, 100\% Speed ..............................................111 
H6 BT005D test 1, full load resistive, 50\% speed ............................................... 112

H7 BT005D test 1, full load resistive, 25\% speed ................................................ 112

H8 BT005D test 2, light load resistive, 100\% speed ............................................. 113

H9 BT005D test 2, light load resistive, 50\% speed .............................................. 113

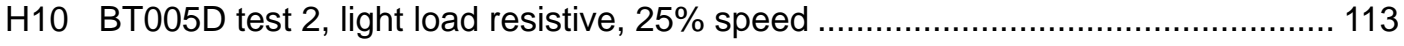

H11 BT005D test 3, motor and resistive loads, 100\% speed ....................................... 114

H12 BT005D test 3, motor and resistive loads, 50\% speed ......................................... 114

H13 BT005D test 3, motor and resistive loads, 25\% speed ....................................... 114

H14 BT005D transient test, motor startup, $50 \mathrm{hp}$ motor across the line start ................ 115

H15 BT005D transient test, motor startup, 20 hp motor ASD operation ....................... 116

J1 Peak load shutdown test, data acquisition parameters....................................... 122

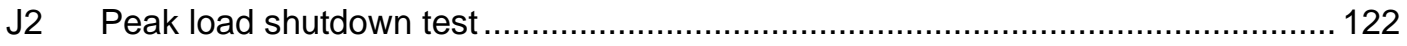

K1 Sustained load test, data acquisition parameters …......................................... 128

L1 Sustained load step test, data acquisition parameters ................................... 131

L2 Sustained load step test, 100\% sustained load capacity test ............................. 131

M1 Overload test, data acquisition parameters ........................................................ 135

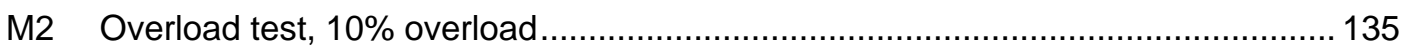

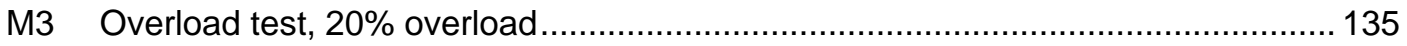

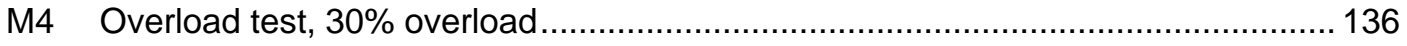

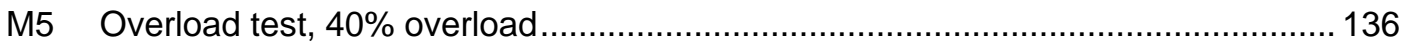

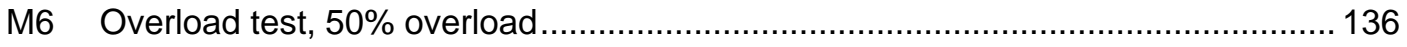

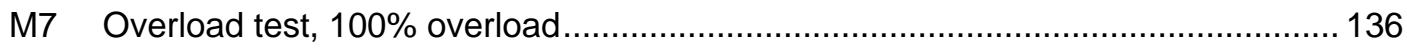

N1 Residential profile test. data acquisition parameters …........................................ 139

N2 Residential profile test, 24-hr example (page 1) ............................................... 140

N3 Residential profile test, 24-hr example (page 2) ............................................... 141

N4 Residential profile test, 24-hr example (page 3) ................................................ 142

N5 Residential profile test, 24-hr example (page 4) ................................................. 143

O1 Residential profile test, data acquisition parameters .......................................... 147

O2 Residential profile test, temperature and humidity test table ............................. 147

P1 Combined heat and power test, data acquisition parameters.............................. 150

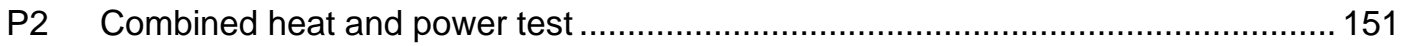

Q1 Fifteen (15) amp circuit breaker overload test, data acquisition parameters .......... 154

Q2 Fifteen (15) amp circuit breaker overload test .................................................. 154

R1 Fifteen (15) amp breaker short circuit test, data acquisition parameters ............... 158

R2 Fifteen (15) amp breaker short circuit test, short circuit test table ......................... 158

S1 Power grid simulation test, data acquisition parameters.................................... 163

S2 Power grid simulation test, grid simulator feedback data to be recorded ............... 163 
S3 Power grid simulation test, frequency deviation test.......................................... 163

S4 Power grid simulation test, voltage surge/sag test............................................ 164

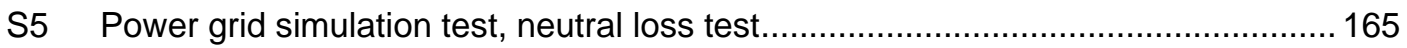




\section{Conversion Factors}

Non-SI ${ }^{*}$ units of measurement used in this report can be converted to SI units as follows:

\begin{tabular}{|c|c|c|}
\hline Multiply & By & To Obtain \\
\hline acres & $4,046.873$ & square meters \\
\hline cubic feet & 0.02831685 & cubic meters \\
\hline cubic inches & 0.00001638706 & cubic meters \\
\hline degrees (angle) & 0.01745329 & radians \\
\hline degrees Fahrenheit & $(5 / 9) \times\left({ }^{\circ} \mathrm{F}-32\right)$ & degrees Celsius \\
\hline degrees Fahrenheit & $(5 / 9) \times\left({ }^{\circ} \mathrm{F}-32\right)+273.15$ & kelvins \\
\hline feet & 0.3048 & meters \\
\hline gallons (U.S. liquid) & 0.003785412 & cubic meters \\
\hline horsepower (550 ft-lb force per second) & 745.6999 & watts \\
\hline inches & 0.0254 & meters \\
\hline kips per square foot & 47.88026 & kilopascals \\
\hline kips per square inch & 6.894757 & megapascals \\
\hline miles (U.S. statute) & 1.609347 & kilometers \\
\hline pounds (force) & 4.448222 & newtons \\
\hline pounds (force) per square inch & 0.006894757 & megapascals \\
\hline pounds (mass) & 0.4535924 & kilograms \\
\hline square feet & 0.09290304 & square meters \\
\hline square miles & $2,589,998$ & square meters \\
\hline tons (force) & $8,896.443$ & newtons \\
\hline tons ( 2,000 pounds, mass) & 907.1847 & kilograms \\
\hline yards & 0.9144 & meters \\
\hline
\end{tabular}

\footnotetext{
*Système International d'Unités ("International System of Measurement"), commonly known as the "metric system."
} 


\section{Preface}

This study was conducted for the Office of the Director, Defense, Research, and Engineering (ODDR\&E), under Work Unit number, 006G7B, "Climate Change Fuel Cells." The technical monitor was Mr. Bob Boyd, ODDR\&E.

The work was performed by the Energy Branch (CF-E), of the Facilities Division (CF), Construction Engineering Research Laboratory (CERL). The CERL Principal Investigators were Michael J. Binder and Franklin H. Holcomb. Part of this work was done by Concurrent Technologies Corporation (CTC), Johnstown, PA under National Defense Center for Environmental Excellence (NDCEE) Task Order N.211, Contract No. DAAE30-98-C-1050. Robert J. Unger and Scott Kenner are associated with CTC. The technical editor was William J. Wolfe, Information Technology Laboratory. Dr. Thomas Hartranft is Chief, CEERD-CFE, and L. Michael Golish is Chief, CEERD-CF. The associated Technical Director was Gary W. Schanche, CEERD-CVT. The Director of CERL is Dr. Alan W. Moore.

CERL is an element of the U.S. Army Engineer Research and Development Center (ERDC), U.S. Army Corps of Engineers. The Commander and Executive Director of ERDC is COL James Rowan, EN and the Director of ERDC is Dr. James R. Houston. 


\section{Introduction}

\section{Background}

Fuel cell power plants can provide improvements in energy conservation and reduced environmental impacts for many Department of Defense (DOD) applications. In fiscal year 1993 (FY93), Congress appropriated $\$ 18$ million to advance the use of phosphoric acid fuel cell (PAFC) power plants at DOD installations. An additional $\$ 18.75$ million was appropriated in FY94 to expand the program. The Army, Air Force, and Navy/Marine Corps each received \$6 million for the purchase, installation, and operation of the fuel cell power plants in FY93, and $\$ 6.25$ million in FY94. By November 1997, DOD had installed 30 PAFC power plants throughout the continental United States and Alaska. The program has successfully demonstrated the capability of the PAFC technology by generating more than 101,977 MWh of electricity through September 2000.

The U.S. Army Engineer Research and Development Center, Construction Engineering Research Laboratory (ERDC/CERL) managed this program. CERL's activities included developing turnkey PAFC packages, devising site selection criteria, screening DOD candidate installation sites using selection criteria, evaluating viable applications at each candidate site, coordinating fuel cell site designs, overseeing installation and acceptance of the power plants, and monitoring and reporting the performance of the fleet. Information on the program is available through the world-wide web (WWW) at:

http://www.dodfuelcell.com

Currently, the ERDC/CERL Fuel Cell Technology Program facilitates the development of Fuel Cell Technology to achieve performance and cost goals expeditiously and provide a means to deploy technology improvements while maintaining reliability. This work provided testing and evaluations, in cooperation with United Technologies Corp. (UTC) Fuel Cells of a PC25C. This test and evaluation effort was undertaken to support life-cycle-cost reduction and performance improvement goals. This program also undertook to provide the capability for independent design assessments of alternative technology fuel cell system configurations and components for achieving lower life cycle cost either through re- 
duced capital cost, reduced operation and maintenance (O\&M) costs, or increased performance and reliability.

\section{Objective}

The objective of this work was to test and evaluate a UTC Fuel Cells 200 kilowatt (kW) PC25C Phosphoric Acid Fuel Cell Power Plant (PAFC) to achieve lifecycle-cost reduction and performance improvements.

\section{Approach}

In this work researchers:

2. Designed and constructed the Department of Defense (DOD) Fuel Cell Test and Evaluation Center (FCTec) within the Environmental Technology Facility (ETF) at Concurrent Technologies Corporation (CTC), a National Resource for the independent, unbiased testing and validation of fuel cell power plants for military and commercial applications. This included the acquisition and installation of testing equipment within the FCTec to support PC25C testing and evaluation.

3. Acquired and installed an UTC Fuel Cells $200 \mathrm{~kW}$ PC25C Phosphoric Acid Fuel Cell Power Plant with customized capabilities for supporting the test objective.

4. Acquired and installed testing equipment within the FCTec for the support of AVISTA SR 12 modular PEM generator and similar smaller fuel cell power plant systems.

5. Provided testing to support the performance improvement objectives of the ERDC/CERL fuel cell program.

\section{Scope}

This work focused on the testing and evaluation of UTC Fuel Cells $200 \mathrm{~kW}$ PC25C PAFC Power Plant.

\section{Mode of Technology Transfer}

It is anticipated that the material collected and developed during this study may be presented in workshops and as a Proponent Sponsored Engineer Corps Training (PROSPECT) course through the Corps of Engineers, Huntsville Engineering 
and Support Center. This material will also be made publicly available through the world-wide web at: www.cecer.army.mil 


\section{Summary of Completed Tests}

Ten tests were performed by CTC on the PC25C. Several of the tests required re-valuation and re-testing to assure proper results. Two of the originally scheduled tests were not performed because of changes in scope of UTC Fuel Cells and ERDC/CERL. The development of a web based FTP site allowed for the quick transfer of large test data files to the fuel cell manufacturers as well as to ERDC/CERL. The test data has been transmitted to both UTC Fuel Cells and ERDC/CERL via the FCTec FTP site.

\section{Modification 1 Additional Activities}

\section{Emissions BT001C}

\section{Objective}

CTC performed exhaust emission sampling on the PC25C during the new baseline power plant evaluation. This test evaluated the level of emissions released from the PC25C during operation on natural gas. The measured values allow for comparison to past PC25C fuel cell emission data from the initial testing performed at the start up of the system.

\section{Activity}

The emission output from the power plant was monitored and tested during operation with 100 percent utility natural gas. The power plant was operated in the grid-connect mode with no customer heat recovery, at $100 \mathrm{~kW}$ and $200 \mathrm{~kW}$ power levels. The test methods used for all test parameters conform to Environmental Protection Agency (EPA) protocols. These methods included Method 1 for location of sampling ports and Method 2 for measuring velocities in a stack. The following instrumental procedures were used as well:

- Method 1 Sample and Velocity Traverse for Stationary Sources

- Method 2C Determination of Stack Gas Velocity and Volumetric Flow Rate in small Stacks (standard Pitot tube)

- Method 3 Determination of $\mathrm{O}_{2}$ and $\mathrm{CO}_{2}$ Concentrations in Emissions from Stationary Sources 
- Method 3A Determination of Oxygen and Carbon Dioxide Concentrations in Emissions from Stationary Sources

- Method 4 Determination of Moisture Content in Stack Gases

- Method 7E Determination of Nitrogen Oxide Emissions from Stationary Sources (Instrument Analyzer Procedure)

- Method 10 Determination of Carbon Monoxide from Stationary Sources

- Method 18 Measurement of Gaseous Organic Compound Emissions by Gas Chromatography

- Method 25A Determination of Total Gaseous Organic Concentration Using a Flame Ionization Analyzer.

\section{Conclusion}

The test results were documented to allow for future comparison. The test was performed to monitor carbon monoxide (CO), nitrogen oxides (NOx), volatile organic compounds (VOC), total hydrocarbons (THC), and sample temperatures. Excess oxygen $\left(\mathrm{O}_{2}\right)$ was also measured at the Power Plant exhaust during the monitoring period (Table 1). The system emission output is unchanged from the initial start up at the beginning of system life. Some values appeared to be lower at mid life testing of the power plant system. These values are indicative of the use of measurement devices during the second phase of testing that have an improved accuracy over the ones used during the first round of testing. Overall the values are low and continued to be low after system operation.

Table 1. Pounds per MW-hr emissions of fuel cell gases.

\begin{tabular}{|l|c|c|c|c|c|c|c|}
\hline $\begin{array}{l}\text { Power } \\
\text { Level }\end{array}$ & $\begin{array}{c}\text { Analysis } \\
\text { Date }\end{array}$ & $\begin{array}{c}\text { Total Hydro- } \\
\text { carbons }\end{array}$ & $\begin{array}{c}\text { Carbon } \\
\text { Monoxide }\end{array}$ & $\begin{array}{c}\text { Carbon } \\
\text { Dioxide }\end{array}$ & $\begin{array}{c}\text { Oxides of } \\
\text { Nitrogen } \\
\text { OxOx) }\end{array}$ & $\begin{array}{c}\text { Oxides of } \\
\text { Sulfur } \\
\text { (SOx) }\end{array}$ \\
\hline $100 \mathrm{~kW}$ & Feb 2000 & 0.042 & 0.080 & 0.226 & 0.303 & 0.112 & Not Tested \\
\hline $100 \mathrm{~kW}$ & Oct 2002 & 0.003 & $<0.001$ & 0.069 & 0.149 & 0.019 & $<0.002$ \\
\hline $200 \mathrm{~kW}$ & Feb 2000 & 0.007 & $<0.002$ & 0.177 & 0.173 & 0.068 & Not Tested \\
\hline $200 \mathrm{~kW}$ & Oct 2002 & $<0.001$ & 0.006 & 0.160 & 0.167 & 0.024 & $<0.002$ \\
\hline
\end{tabular}

\section{Grid Independent BT005B}

\section{Objective}

The grid independent testing presented the power plant with combinations of both resistive and motor loads to simulate the power plant's ability to handle overloads. Presently, published specifications on the power plant list its steadystate capacity at $200 \mathrm{~kW}$ with overload capabilities up to 5 seconds at $240 \mathrm{~kW}$. Documenting the actual overload possibilities provided increased flexibility for system planning for all PC25C users. The system response was monitored with 
the FCTec Control and Data Acquisition System (CDAQ), and a Dranetz disturbance Analyzer.

\section{Activity}

For this test, the PC25C was set up for grid independent operation. A resistive load bank was used as the electrical loading means. All runs of this test began with a constant $200 \mathrm{~kW}$ resistive load. Overloads were applied as a step change, while monitoring power plant response. Overload tests started with the addition of a nominal overload. Further testing progressed in $5 \mathrm{~kW}$ overload steps until a steady state operating level was reached.

Starting at the same $200 \mathrm{~kW}$ power level, momentary overloads of varying sizes were applied for limited periods of time including 1, 2, 3, and 4 seconds. This tested the power plant's ability to maintain operation with short-term overloads.

Nominal loading levels and system response were recorded, along with specific output voltage, current, wattage, and transient voltage/current response, for each test.

\section{Conclusion}

This measurement of the fuel cells power plant's ability to manage overloads was performed both under the original Modification 2 testing as well as under the Modification 1 additional testing phase. All data and graphical information was transmitted to ERDC/CERL and UTC Fuel Cells on completion of the tests. The second operation of the overload capabilities of the PC25C allowed for a comparison of new power plant capabilities vs. a system approaching 22,000 hrs of use.

Figure 1 identifies the current impulse and corresponding voltage sag indicative of the overload conditions during the final test prior to a shutdown event. As the time duration for the overload is greater, the stress to the fuel cell system increases. The system capabilities at mid life decreased from the initial operation capabilities of $250 \mathrm{~kW}$ for 5 seconds and $220 \mathrm{~kW}$ for 10 seconds to $220 \mathrm{~kW}$ for 5 seconds at mid life. 


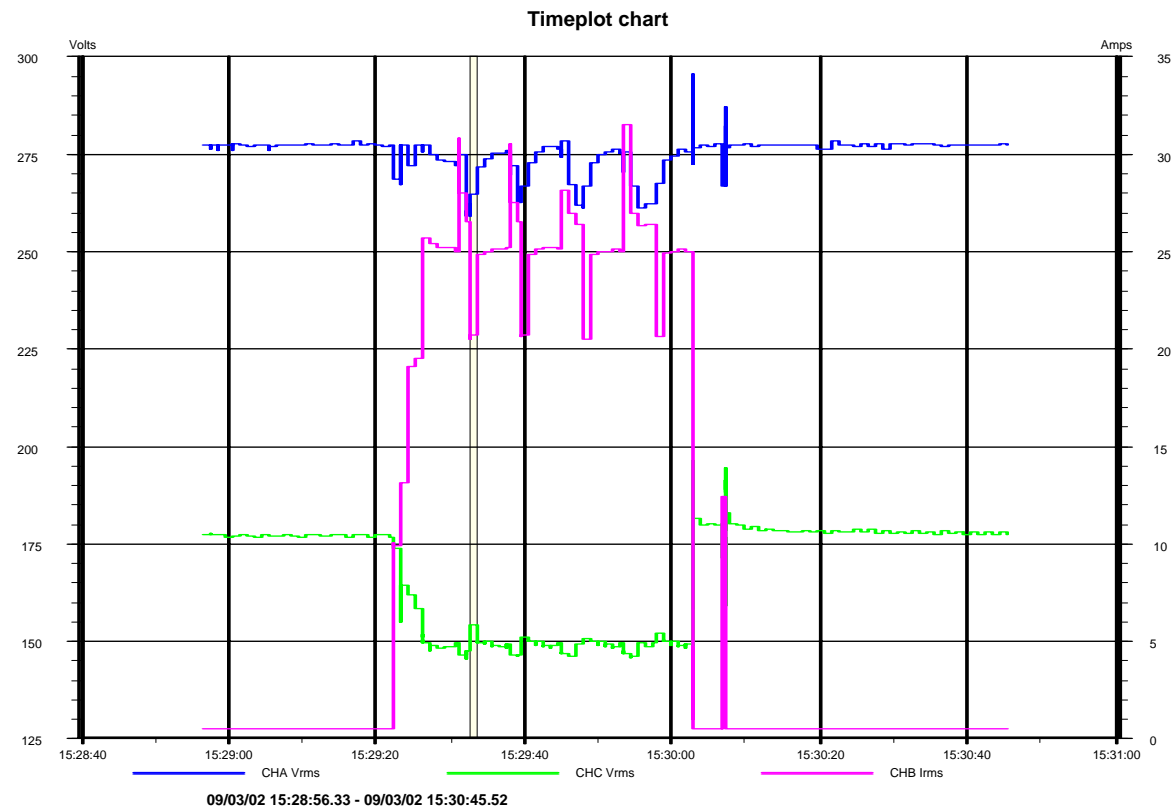

Figure 1. Overload time plot chart at $220 \mathrm{~kW}$ for 1, 2, 3, 4, and 5-second intervals.

\section{Grid Independent BT005D}

\section{Objective}

Obtain the necessary information to determine the power quality parameters of the PC25C while supplying varying electrical loads. Measurements used to indicate the relative quality of supplied electrical power include such items as voltage regulation (both steady state and transient), and wave shape quality (total harmonic distortion, THD).

\section{Activity}

For this test the power plant was operated in grid independent mode, and measurements taken at various steady state resistive and inductive (motor) load levels. Readings were achieved while cycling through a series of varying (transient) load levels. Additionally, a $20 \mathrm{hp}$ pulse width modulated (PWM) drive and softstart controllers were used as non-linear loads to determine their effect on the output voltage quality.

Measurements were taken using a Dranetz line analyzer, and a high-speed data acquisition system. Instantaneous voltage, current, and $\mathrm{kW}$ data were captured. The data were reported to ERDC/CERL and UTC Fuel Cells for comparison with unit specifications and IEEE standards. 


\section{Conclusion}

Figure 2 is an example of the maximum voltage distortion of the PC25C power plant when exposed to the non-linear load of a $20 \mathrm{hp}$ adjustable speed drive operating at 25 percent load to achieve the greatest distortion. The corresponding current distortion is identified in Figure 3. The 2.93 percent Voltage Total Harmonic Distortion (THD) from the PC25C power plant is well within the IEEE 519 requirements. Even at mid life of the fuel cell stack, the system responds extremely well to high levels of nonlinear loads.

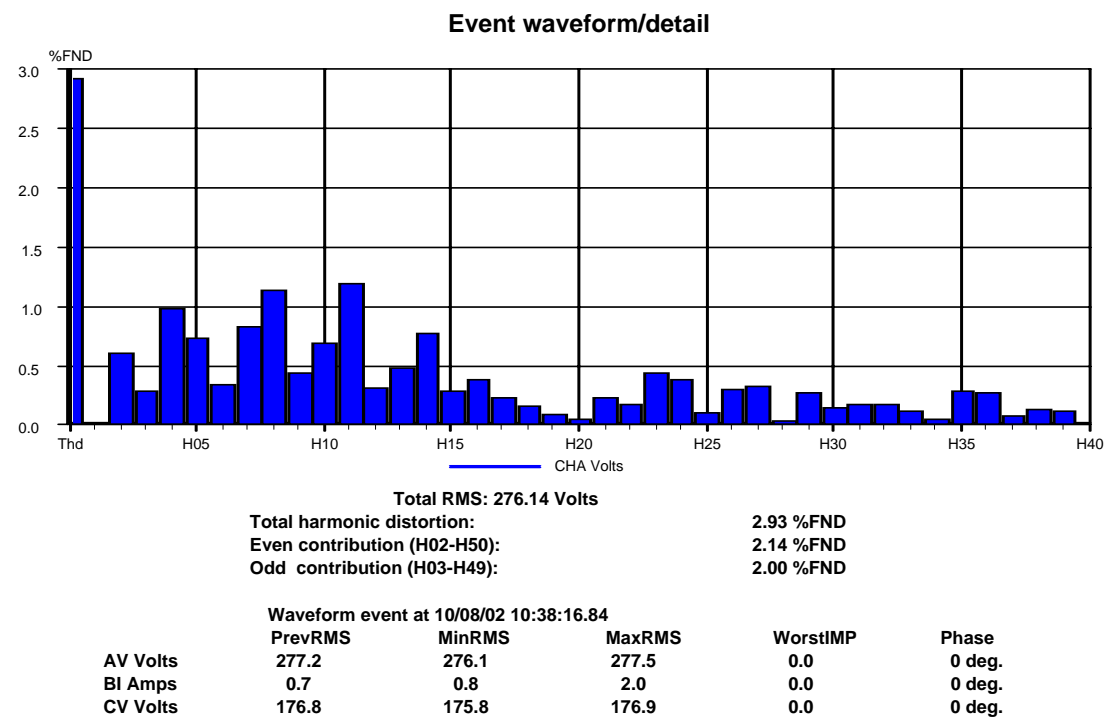

Figure 2. Maximum voltage distortion experienced under non-linear load.

Event waveform/detail

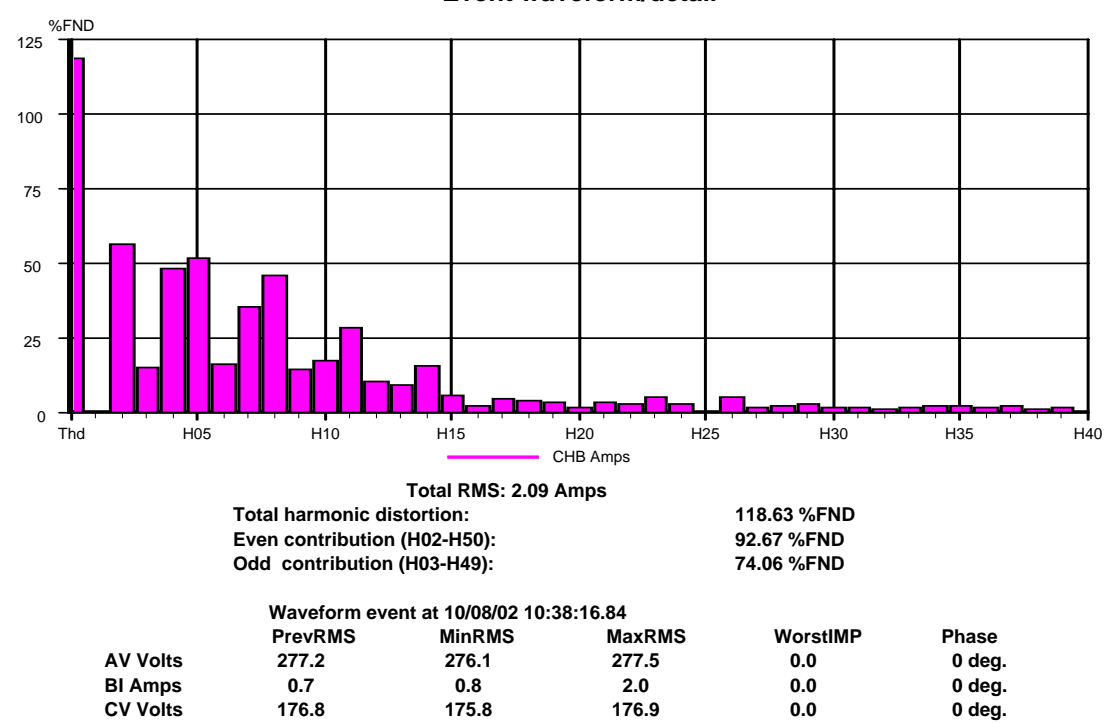

Figure 3. Maximum current distortion under nonlinear load. 


\section{Modification 2 Activities}

\section{Pre Test Hydrodesulfurizer (HDS) BT001A}

\section{Objective}

This testing investigated the operation of the hydrodesulfurizer (HDS) bed in the integrated low temperature shift converter (ILS). This task is to define possible improvements to the hydrodesulfurizer catalyst bed configuration that will improve the "sulfur slip" presently experienced in the PC25C fleet. "Sulfur slip" causes poisoning of the reformer catalyst. Reduction in the reliability and life of the power plant is the outcome. Testing included catalyst bed heater locations, method of heater control, temperature sensor location, and revised temperature set points. A schematic of the heater locations and the standard thermocouple positions is included with the test plan information in Appendix B.

\section{Activity}

Temperature data from a specially instrumented hydrodesulfurizer (HDS) system identified the optimum temperature profile from top to bottom of the catalyst bed. Maximum and minimum design temperatures in the bed were being exceeded using a typical on/off control scheme. It is theorized that the excessive temperature gradients in the HDS catalyst bed, induced by the placement and cycling of the HTR002 heaters, contributed to the "sulfur slip."

To test various options for temperature profile improvement in the HDS, an array of 33 additional thermocouples and three additional heaters, for a total of six, were added to the HDS bed in accordance with drawings and instructions provided by UTC Fuel Cells. UTC Fuel Cells also provided a formalized test plan that included operating the power plant at two power levels, $80 \mathrm{~kW}$ and $200 \mathrm{~kW}$, for evaluation of heater control while using three of the six available heaters and one of several thermocouples for temperature control during the various test configurations. Test configurations were selected that would lead to a definition of a heater and control thermocouple design that could be implemented in field power plants. The test plan also included provisions for sampling the HDS exit gas for sulfur compounds.

Testing of the HDS bed for sulfur removal was conducted in three phases. Phase I included testing of the desulfurization unit in normal configuration, Phase II used various heater configurations, and Phase III used an electronic process heater control to provide a very narrow controlled temperature. To prepare for the testing additional thermocouples and heaters were added to the HDS bed. 
The heaters provided a means for varying the heated zones inside the HDS while the thermocouples provided for the measurement of internal temperatures across the HDS bed. The new thermocouple information was included within the data acquisition system to allow reporting and plotting of the values.

Phase I testing was performed by collecting samples of natural gas and processed gases at access ports AP001, reformer inlet and AP003, reformer outlet in a batch method, using Suma canisters. The canisters were sent to AirToxics in California for sulfur compound speciation and measurement using American Society for Testing and Materials (ASTM) Method 5504.

A series of tests were conducted to document the temperature profile in the HDS bed using the bill-of-material heaters, control thermocouple, and on/off heater control. Temperature data were collected at two power levels, $80 \mathrm{~kW}$ and $200 \mathrm{~kW}$. With this heater and control configuration, a maximum temperature range within the bed of $385^{\circ} \mathrm{F}$ from the hottest to coldest thermocouple was observed at $200 \mathrm{~kW}$ with the heaters on and at the top of the temperature cycle. It would reduce to $150{ }^{\circ} \mathrm{F}$ at the bottom of the cycle. Per UTC Fuel cells, this large temperature range exceeds the optimum range for full use of the hydrodesulfurizer catalyst and sulfur absorbent. In addition, the top-to-bottom temperature profile within the bed showed that the coldest zone was at the top of the bed where the natural gas enters and the hottest zone was near the bottom. This is just the opposite of the desired profile. A plot of this temperature data, provided by UTC Fuel Cells, is in Figure 4.

UTC Fuel Cells suggested that the top-to-bottom temperature profile identified that it was desirable to revise the heater placement on the HDS vessel to add more heat to top of the bed instead of the bottom as in the original configuration. Three new heater configurations were tested to accomplish this, using heater bands near the top and above the bed for inlet gas heating. This segment of testing used a control thermocouple location higher in the bed.

Per UTC Fuel Cells, the first configuration tested gave unacceptable results with excessively high local bed temperatures. The next configuration successfully increased the temperature at the top of the bed as compared to the baseline data but the temperature range within the bed, now $463^{\circ} \mathrm{F}$, was worse than the baseline configuration. The identification of a third and more desirable configuration for the heater bands was accomplished. To retain the improved top-to-bottom of temperature profile but reduce the excessive temperature range within the bed, two heaters near the top of the bed and one above the bed on the vessel wall gave the best results. 
$3 / 21$

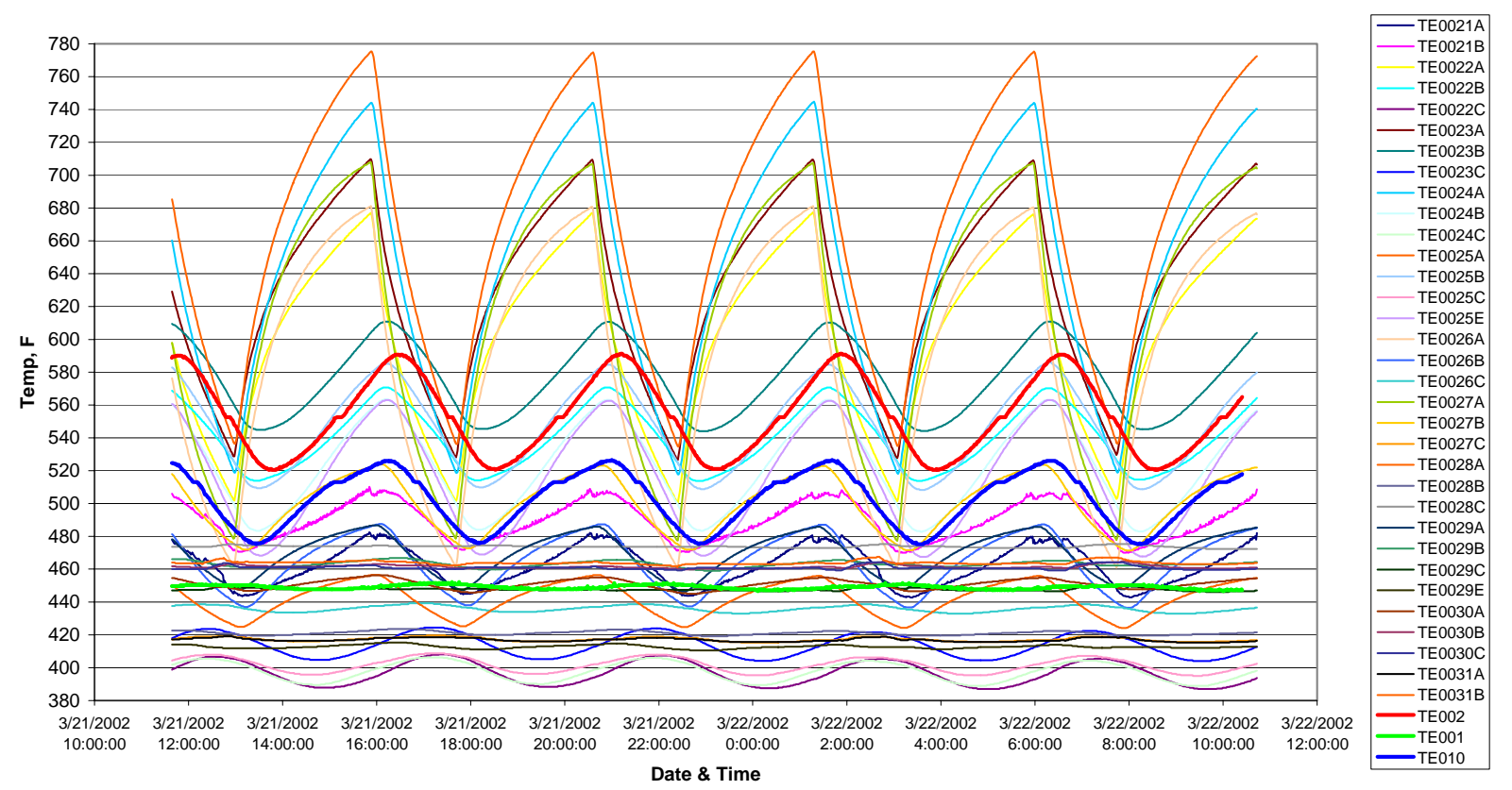

Figure 4. UTC fuel cells HDS temperature cycling, BOM configuration.

CTC relocated and repositioned the control thermocouple to reduce the magnitude of the temperature swings within the catalyst bed as the heaters cycle. CTC moved the control thermocouple closer to the vessel wall and relocated it to a higher elevation, near the newly located heaters.

These modifications dramatically improved the temperature control. UTC Fuel Cells were pleased with the outcome whereby the period of the on/off heater cycle was reduced from $3^{1 / 4}$ hrs to 20 minutes and the maximum temperature fluctuation at any local area in the bed was reduced from $200^{\circ} \mathrm{F}$ to $26^{\circ} \mathrm{F}$. In addition, the worst case temperature spread within the bed at the top of the temperature cycle was reduced from $385^{\circ} \mathrm{F}$ to $287^{\circ} \mathrm{F}$. UTC Fuel Cells graphed the temperature profile in the bed under this configuration (Figure 5).

CTC sampled the hydrodesulfurizer exit gas into batch containments and delivered them to the outside lab for sulfur analysis. Using a lower detection level that ranged from 7.5 to $10 \mathrm{ppbV}$, no sulfur was detected. 


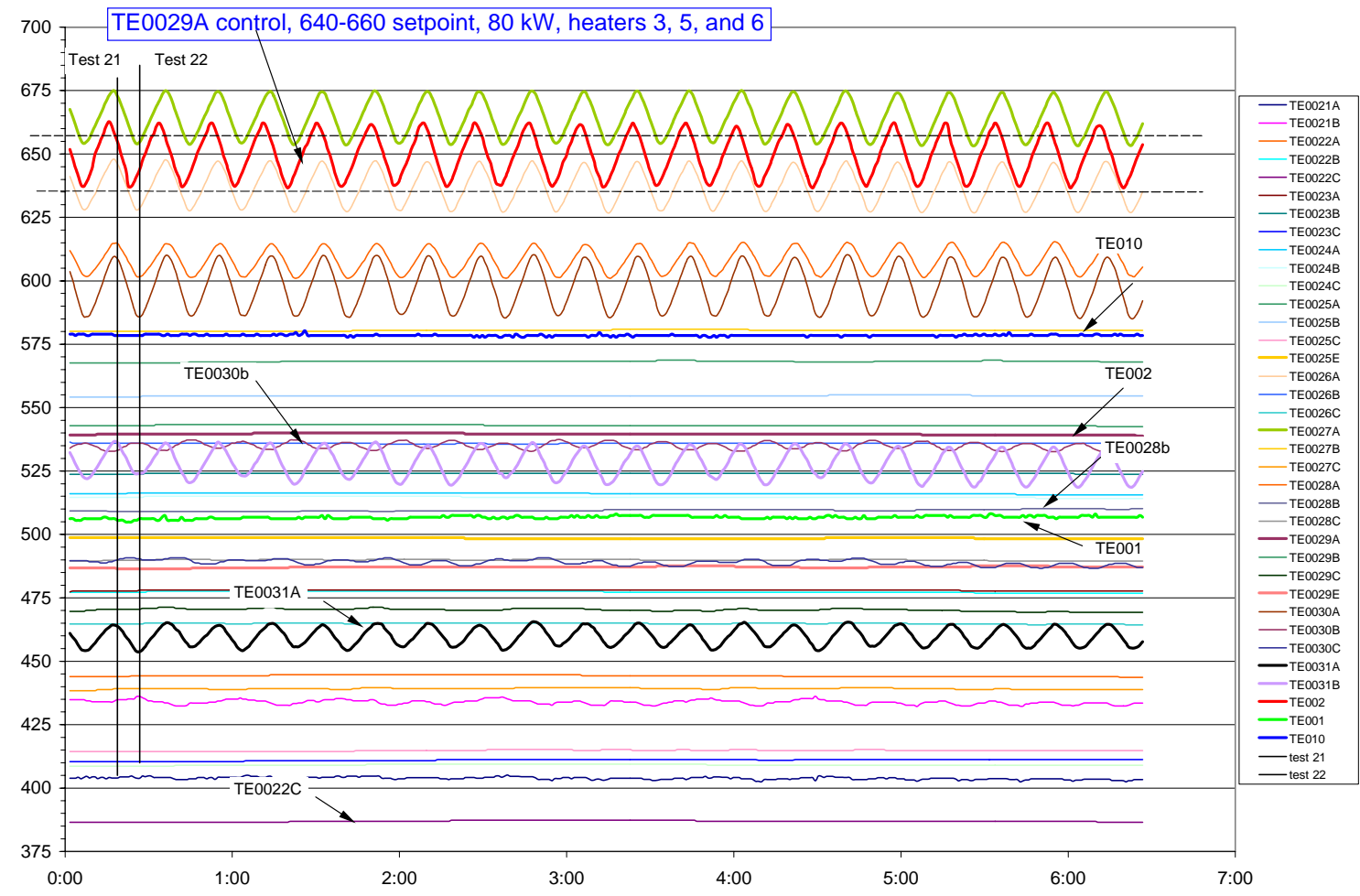

Figure 5. Improved HDS temperature profile, relocated heaters and control TC.

Before Phase II testing began, a heated sample line and pump were added to transfer the gas sample from port AP003, reformer outlet, to a Gas Chromatographic system (GC) upgraded by OI Analytical with a Pulsed Flame Photometric Detector (PFPD). The PFPD allows for the detection and measurement of low levels of sulfur in sample compounds. The gas chromatograph analysis provided a measurement of the effects of varying the heating profile, thermal zones, and operational parameters on sulfur removal. Using the direct capture and measure method provided by the specialized gas chromatograph, accurate immediate measurements of the sulfur concentrations were possible. Comparisons of the canister and gas chromatograph methods were provided to UTC Fuel Cells. The gas chromatograph method allowed for an improvement in sulfur detection in all cases.

Phase II testing included the addition of an electronic system for temperature control. CTC installed this system to allow finite control of the monitored temperature. On implementation, the control temperatures no longer had an on/off dead band. The Phase II testing varied the heater temperatures, changed the location of heated zones, and measured the sulfur species using the gas chromatograph. Optimum operating parameters were identified using these experimental conditions. 
CTC operated the power plant at $80 \mathrm{~kW}$ and $200 \mathrm{~kW}$ using the electronic temperature controller with the heaters and the control thermocouple located in the bill of material, original locations. The results were poor, with the temperature at the control thermocouple location cycling plus or minus $20^{\circ} \mathrm{F}$ about the setpoint, and the cycle period was about $2 \frac{1}{2} \mathrm{hrs}$.

The HDS bed temperature control thermocouple was relocated near the vessel wall at the preferred location determined during earlier testing. Testing of three heater configurations was conducted with a set point temperature of $640{ }^{\circ} \mathrm{F}$ and with the power plant operating at $80 \mathrm{~kW}$ and $200 \mathrm{~kW}$. Based on the HDS bed temperature data, a heater configuration to achieve the best temperature profile was identified and it was the same configuration that gave the best results during Phase 1 testing when the on/off heater control was used.

The gas chromatograph sampled the gas at the HDS exit to identify trace amounts of certain sulfur compounds. Detection of the individual sulfur compounds was above a $2 \mathrm{ppbV}$ level with none detected at levels greater than 8 $\mathrm{ppbV}$. The highest total sulfur level detected (the sum of the individual compound levels) was $16 \mathrm{ppbV}$. The highest sulfur levels were detected shortly after making load change transients, and the peaks seemed to be present for only a few minutes. These sulfur levels are shown in the UTC Fuel Cells Figure 3 at various test conditions.

With a technique established for quantifying very low sulfur levels by gas chromatography, sulfur analyses were repeated with the baseline HDS heater configuration and with the original on/off heater cycling. The highest total sulfur level detected was $8 \mathrm{ppb}$ and the sulfur compound most prevalent was carbonyl sulfide, at about 4 to 5 ppbV.

Sulfur was infrequently found by the sample canister method used in Phase I, and levels were very low when the analysis was performed using the gas chromatograph method in Phase II. The hydrodesulfurizer catalyst activity and overall HDS performance appeared to be acceptable throughout most of the Phase II testing. This is attributed to the relatively clean natural gas in the Johnstown, PA area. This gas contains a moderate amount of sulfur compounds as odorants that are easily reacted in the HDS. In other parts of the country, the natural gas contains high levels of sulfur compounds, some of which may pass through the HDS with the possibility of poisoning the reformer catalyst.

As part of this testing, the control constants for the programming of the electronic heater controller were determined. Satisfactory control constants to achieve smooth temperature control were selected. It was also determined that 
the heater control did not adversely affect the power plant controller. The stability of temperature control with the electronic controller is also indicated in UTC Fuel Cells Figure 6.

Phase III testing attempted to accomplish similar results to the electronic temperature control with the use of the balance of plant on/off controller. This was accomplished by positioning a thermocouple in what UTC Fuel Cells determined would be the optimum location and using the balance of plant on/off controller. This method would provide for a less expensive retrofit if successful.

During Phase III, temperature control was evaluated using the bill-of-material TE010 location but with the thermocouple inserted into the bed only $1 / 4 \mathrm{in}$. This location is about $12 \mathrm{in.} \mathrm{lower} \mathrm{in} \mathrm{the} \mathrm{bed} \mathrm{than} \mathrm{the} \mathrm{control} \mathrm{TC} \mathrm{used} \mathrm{in} \mathrm{Phase} \mathrm{II} \mathrm{but}$ 12 in. higher than the original control thermocouple TE002. Temperature control was evaluated at various power levels and set point temperatures to match the bed temperatures achieved in Phase II. It was confirmed that the TE010 port could be satisfactorily used for temperature control as necessary using a set point temperature of $605^{\circ} \mathrm{F}$.

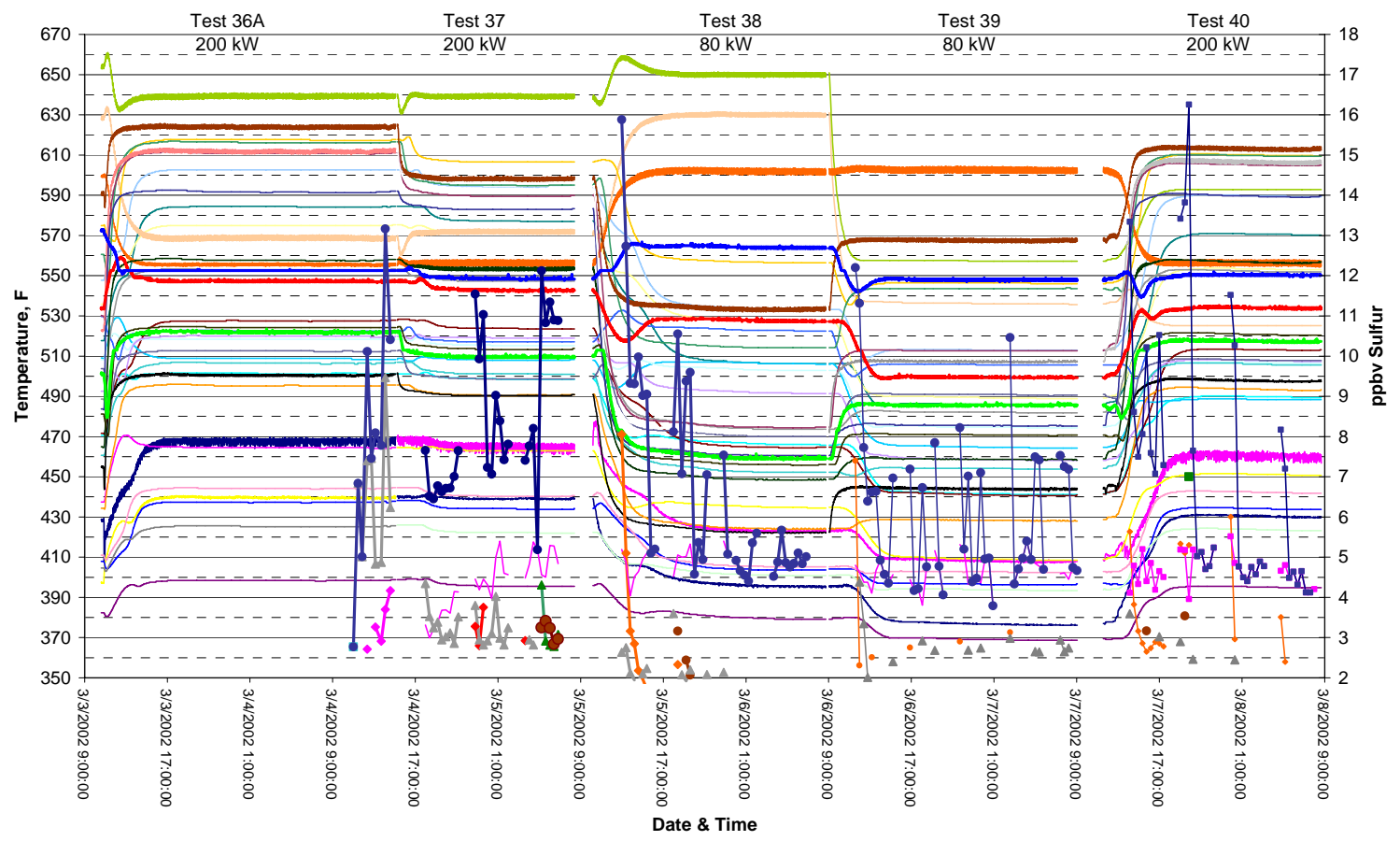

Figure 6. HDS bed temperature with electronic control and sulfur analysis. 


\section{Conclusion}

In Phase I testing, HDS heater and control thermocouple locations were identified that greatly improved the temperature profile in the HDS catalyst bed. The two key changes were: (1) locating the control thermocouple close to the vessel wall, which reduced the heater cycle time, and (2) repositioning the heater bands higher on the vessel wall to produce a more desirable temperature profile, with the hotter zone on top at the gas inlet where the hydrodesulfurizer catalyst will have the greatest activity.

In Phase II testing, a better temperature control, without heater cycling, was obtained by using an electronic, Proportional, Integral, and Derivative (PID) heater controller. In addition to eliminating cycling, the electronic controller will extend heater life by minimizing extreme temperature differentials and thermal fatigue failure of the heater elements.

In Phase III, a practical approach for implementing the new heater control scheme in the PC25C fleet was developed. On dual-fuel ILS units, like the system at the FCTec, an existing thermocouple port on the HDS vessel was used without incurring a high expense or excessive power plant down time for extensive HDS modifications.

The final outcome of the testing resulted in the use of an existing thermocouple location TE 010, the relocation of the thermocouple to a position near the outside wall, and the use of a temperature set point of $605^{\circ} \mathrm{F}$ with the electronic temperature control system. This configuration used the new HDS heater locations at position 3,5 , and 6 . Temperatures at $80 \mathrm{~kW}$ and $200 \mathrm{~kW}$ power levels were satisfactory, varying between $486^{\circ} \mathrm{F}$ and $592^{\circ} \mathrm{F}$. This setup will provide the best overall sulfur removal with a low implementation cost.

\section{Reference Natural Gas Testing BT001B}

\section{Objective}

The Reference Natural Gas (RNG) testing established a baseline of power plant operation in a standard configuration at the beginning of life for use in comparison to subsequent operation over the power plant life and different plant configurations. This test has been repeated at different stages of life to document power plant aging and evaluate the need to re-tune the power plant to optimize performance. This testing assessed the long term effects of the operation of the fuel cell system on the composition of gases produced at various locations through out the system, at various power settings. 


\section{Activity}

For all test runs, the power plant operated on utility natural gas in the grid connect mode with no customer heat recovery. The tests were established and designated by net power output levels to include idle mode, $50 \mathrm{~kW}, 80 \mathrm{~kW}, 100 \mathrm{~kW}$, $125 \mathrm{~kW}, 150 \mathrm{~kW}, 175 \mathrm{~kW}$, and $200 \mathrm{~kW}$. The power plant systems were set up and configured for normal operation per the UTC Fuel Cells PC25C operations manual. Each condition was held a minimum of $3 \mathrm{hrs}$ to ensure a stabilized load condition. Data collected included the power plant RADAR dataset and the CTC provided CDAQ data as well as gas analysis composition via gas chromatograph. CTC and UTC Fuel Cells reviewed all data captured for each power level following the completion of this test series.

Because of some gas chromatograph issues noted during evaluation of the initial test data, portions of the test (Idle, $50 \mathrm{~kW}, 100 \mathrm{~kW}$ and $200 \mathrm{~kW}$ ) were repeated in early May 2000 to confirm these earlier results.

After operating for 15,000 load hours, this test was repeated in January 2002 to determine the need for a re-trim of the reformer temperature schedule to maintain optimum power plant performance.

All pertinent measured, monitored, and computed parameters from the FCTec data acquisition system and the PC25C's existing data acquisition system were recorded and stored for each test run. Specific data samples captured for this test series included:

- Gas analysis $\left(\mathrm{H}_{2}, \mathrm{CO}_{2}, \mathrm{O}_{2}, \mathrm{~N}_{2}, \mathrm{CO}\right.$, and $\left.\mathrm{CH}_{4}\right)$ of the Reformer Process Exit

- Gas analysis $\left(\mathrm{H}_{2}, \mathrm{CO}_{2}, \mathrm{O}_{2}, \mathrm{~N}_{2}, \mathrm{CO}\right.$, and $\left.\mathrm{CH}_{4}\right)$ of the Anode Inlet and Anode Outlet

- Gas analysis $\left(\mathrm{H}_{2}, \mathrm{CO}_{2}, \mathrm{O}_{2}, \mathrm{~N}_{2}, \mathrm{CO}\right.$, and $\left.\mathrm{CH}_{4}\right)$ of the Burner Exhaust

- Gas analysis $\left(\mathrm{H}_{2}, \mathrm{CO}_{2}, \mathrm{O}_{2}, \mathrm{~N}_{2}, \mathrm{CO}\right.$, and $\left.\mathrm{CH}_{4}\right)$ of the Cathode Exit

- Cell Stack Assembly (CSA) cross pressure (anode inlet to cathode inlet)

- Glycol inlet and exit temperatures of cooling module

- Ambient temperature of cooling module area

- Exiting air temperature from cooling module fans

- Cooling module on/off status

- Feed water on/off status.

Gas analysis was performed using a Perkin Elmer auto-system gas chromatograph equipped with a light gas analysis kit. This system uses thermal conductivity detection and a gas-sampling loop to introduce the sample onto a chromatography column. The column consists of a Haye's separation column before the sample enters a molecular sieve column. After injection onto the column, carrier 
gas (8.5 percent Hydrogen in Helium) moves Hydrogen in the sample through both columns to the detector. A valve closes to trap Oxygen, Nitrogen, Carbon Monoxide, and methane on the molecular sieve column while carbon dioxide and other gases (ethane, propane, carbon disulfide, etc.) pass through the Haye's column to the detector. The valve then returns to its original position to move the remaining gases to the detector.

Teflon tubing was used to collect gas samples. A dry sample was introduced to the gas chromatograph by using an impinger to remove bulk water. The sample then passed through a TESTO air-cooled gas drier and finally an impinger filled with desiccant to remove traces of moisture. The sample was drawn through the sample loop using a gas sampling pump.

Calibration of the instrument for the analysis of oxygen, carbon monoxide and carbon dioxide was accomplished using certified compressed gas standards. Calibration for Nitrogen and Hydrogen was performed using pure (99.999 percent) compressed gas standards. A dry gas meter was used to prepare compositions of $20 \% \mathrm{~N}_{2} / 80 \% \mathrm{H}_{2}, 40 \% \mathrm{~N}_{2} / 60 \% \mathrm{H}_{2}, 60 \% \mathrm{~N}_{2} / 40 \% \mathrm{H}_{2}$, and $80 \% \mathrm{~N}_{2} / 20 \% \mathrm{H}_{2}$ in $1.6 \mathrm{cu} \mathrm{ft}$ Tedlar bags. Air was used to confirm Oxygen and Nitrogen calibration curves. Finally, methane calibration was performed by injecting known volumes of pure methane gas using gas-tight syringes into Nitrogen filled Tedlar bags. These calibration methods are documented in the CTC ISO standards.

As a comparison tool, an Anarad testing system supplied by UTC Fuel Cells, collected gas composition data at various power levels. These data were compared to the analytical information received using gas chromatography to verify the results. A hand-held gas analyzer, TESTO 350, was also used to collect Oxygen concentration data on the cathode exit and burner exhaust ports. A spreadsheet form included all data along with the input collected using computerized data acquisition software. This information was transmitted to UTC Fuel Cells by the FCTec File Transfer Protocol (FTP) location.

\section{Conclusion}

The test power plant, SN9194, located within the CTC Environmental Technology Facility (ETF) began operation in November 1999. When the power plant was not engaged in specific testing, it generally operated at $200 \mathrm{~kW}$ during the day and at $80 \mathrm{~kW}$ during the overnight and weekend periods.

With about 600 load hours on the power plant, the reference Natural Gas testing began in mid January 2000. The gas composition at the reformer process exit, the anode inlet and the anode exit were measured via the CTC GC at the power 
levels as outlined in the test information. The initial gas analysis results using the gas chromatograph were invalid because the carrier gas was tainted. After resolving the issue with the gas chromatograph the gas composition was reanalyzed in May 2000 with improved results. Table 2 lists the gas analysis for idle, $50 \mathrm{~kW}, 100 \mathrm{~kW}$, and rated power $200 \mathrm{~kW}$. UTC Fuel Cells provided the fuel conversion and hydrogen use calculations based on the measured composition levels reflected. Testing resulted in a lower than expected steam flow above idle.

Table 2. Gas analysis results, gas chromatograph (May 2000).

Reformer Process Exit

\begin{tabular}{|l|c|c|c|c|c|c|c|l|}
\hline Power & $\mathbf{H}_{2}$ & $\mathrm{CH}_{4}$ & $\mathrm{CO}_{2}$ & $\mathrm{CO}$ & $\mathbf{N}_{2}$ & $\mathrm{O}_{2}$ & Theta & psi \\
\hline Idle & 78.4 & 0.2 & 10.1 & 11.3 & 0.0 & 0.0 & 0.991 & 0.472 \\
\hline $50 \mathrm{~kW}$ & 77.8 & 0.8 & 9.5 & 11.9 & 0.0 & 0.0 & 0.964 & 0.444 \\
\hline $100 \mathrm{~kW}$ & 77.6 & 0.8 & 9.4 & 12.2 & 0.0 & 0.0 & 0.964 & 0.435 \\
\hline $200 \mathrm{~kW}$ & 77.2 & 0.9 & 9.2 & 12.7 & 0.0 & 0.0 & 0.961 & 0.420 \\
\hline
\end{tabular}

Anode Inlet

\begin{tabular}{|l|c|c|c|c|c|c|c|l|}
\hline Power & $\mathbf{H}_{2}$ & $\mathrm{CH}_{4}$ & $\mathbf{C O}_{2}$ & \multicolumn{1}{l}{$\mathbf{C O}$} & $\mathbf{N}_{2}$ & $\mathbf{O}_{2}$ & Theta & psi \\
\hline Idle & 81.8 & 0.2 & 17.8 & 0.2 & 0.0 & 0.0 & 0.989 & 0.989 \\
\hline $50 \mathrm{~kW}$ & 81.0 & 0.7 & 18.0 & 0.3 & 0.0 & 0.0 & 0.963 & 0.984 \\
\hline $100 \mathrm{~kW}$ & 81.2 & 0.7 & 17.9 & 0.2 & 0.0 & 0.0 & 0.963 & 0.989 \\
\hline $200 \mathrm{~kW}$ & 80.5 & 0.8 & 17.7 & 1.0 & 0.0 & 0.0 & 0.959 & 0.947 \\
\hline
\end{tabular}

Anode Exit

\begin{tabular}{|l|c|c|c|c|c|c|c|c|c|}
\hline Power & $\mathbf{H}_{2}$ & $\mathrm{CH}_{4}$ & $\mathbf{C O}_{2}$ & $\mathbf{C O}$ & $\mathbf{N}_{2}$ & $\mathbf{O}_{2}$ & Theta & psi & $\mathbf{U H}_{2}$ \\
\hline Idle & 49.6 & 0.5 & 49.6 & 0.3 & 0.0 & 0.0 & 0.990 & 0.994 & 0.781 \\
\hline $50 \mathrm{~kW}$ & 49.6 & 1.7 & 48.1 & 0.6 & 0.0 & 0.0 & 0.966 & 0.988 & 0.769 \\
\hline $100 \mathrm{~kW}$ & 50.9 & 1.6 & 47.0 & 0.5 & 0.0 & 0.0 & 0.967 & 0.989 & 0.760 \\
\hline $200 \mathrm{~kW}$ & 50.1 & 2.1 & 45.6 & 2.2 & 0.0 & 0.0 & 0.958 & 0.954 & 0.757 \\
\hline
\end{tabular}

Theta: Fuel Conversion

\section{$\mathrm{UH}_{2}$ : Hydrogen Use}

As a result, an indirect steam flow measurement was made via a water tank (TNK450) draw down procedure. This procedure restricts the water tank return flows (TMS blow down and condensate) from the water tank. With the drop in TNK450 level, an estimate of the steam flow was to be made. UTC Fuel Cells determined that by the results of this testing at $100 \mathrm{~kW}$ and $200 \mathrm{~kW}$ the process steam schedule was deficient by approximately 10 percent. The steam schedule was subsequently increased and the gas composition re-evaluated at $100 \mathrm{~kW}$, $150 \mathrm{~kW}$ and $200 \mathrm{~kW}$ power levels. Table 3 lists the results of a representative revised steam schedule's gas analysis. 
Table 3. Gas analysis results, gas chromatograph (August 2000).

Reformer Process Exit

\begin{tabular}{|l|l|c|c|c|l|l|l|l|}
\hline Power & $\mathbf{H}_{2}$ & $\mathbf{C H}_{4}$ & $\mathbf{C O}_{2}$ & $\mathbf{C O}$ & $\mathbf{N}_{2}$ & $\mathbf{O}_{2}$ & Theta & psi \\
\hline $100 \mathrm{~kW}$ & 78.3 & 1.2 & 9.9 & 10.3 & 0.3 & 0.0 & 0.944 & 0.490 \\
\hline $150 \mathrm{~kW}$ & 77.7 & 1.1 & 10.4 & 10.5 & 0.3 & 0.0 & 0.950 & 0.498 \\
\hline $200 \mathrm{~kW}$ & 78.5 & $0.1^{\star}$ & 9.3 & 11.8 & 0.3 & 0.0 & 0.995 & 0.441 \\
\hline
\end{tabular}

Anode Inlet

\begin{tabular}{|l|l|l|l|l|l|l|l|l|}
\hline Power & $\mathbf{H}_{2}$ & $\mathrm{CH}_{4}$ & $\mathbf{C O}_{2}$ & $\mathbf{C O}$ & $\mathbf{N}_{2}$ & $\mathbf{O}_{2}$ & Theta & psi \\
\hline $100 \mathrm{~kW}$ & 80.4 & 1.1 & 18.0 & 0.1 & 0.3 & 0.0 & 0.942 & 0.944 \\
\hline $150 \mathrm{~kW}$ & 80.5 & 1.0 & 17.9 & 0.3 & 0.3 & 0.0 & 0.948 & 0.983 \\
\hline $200 \mathrm{~kW}$ & 80.7 & 0.7 & 17.7 & 0.7 & 0.2 & 0.0 & 0.963 & 0.962 \\
\hline
\end{tabular}

Anode Exit

\begin{tabular}{|l|c|c|c|c|c|l|l|l|l|}
\hline Power & $\mathbf{H}_{2}$ & $\mathbf{C H}_{4}$ & $\mathbf{C O}_{2}$ & $\mathbf{C O}$ & $\mathbf{N}_{2}$ & $\mathbf{O}_{2}$ & Theta & psi & $\mathbf{U H}_{2}$ \\
\hline $100 \mathrm{~kW}$ & 48.5 & 2.9 & 47.4 & 0.5 & 0.8 & 0.0 & 0.943 & 0.990 & 0.770 \\
\hline $150 \mathrm{~kW}$ & 49.3 & 2.5 & 46.5 & 0.8 & 0.9 & 0.0 & 0.950 & 0.983 & 0.764 \\
\hline $200 \mathrm{~kW}$ & 50.4 & 1.9 & 45.2 & 1.9 & 0.6 & 0.0 & 0.961 & 0.960 & 0.757 \\
\hline
\end{tabular}

The power plant was shut down in December 2001 to repair a slipped manifold seal in the cell stack. CTC performed a gas analysis using the UTC Fuel Cells Anarad, a three-channel non-dispersive infrared (NDIR) gas analyzer, after the system was restarted. Table 4 lists the gas analysis after the repair and restart.

Table 4. Gas analysis results, field anarad (December 2001).

Reformer Process Exit

\begin{tabular}{|l|c|c|c|c|c|c|c|c|}
\hline Power & $\mathbf{H}_{2}$ (by diff) & $\mathbf{C H}_{4}$ & $\mathbf{C O}_{2}$ & $\mathbf{C O}$ & $\mathbf{N}_{2}$ & $\mathbf{O}_{2}$ & Theta & Psi \\
\hline $80 \mathrm{~kW}$ & 77.4 & 1.0 & 10.8 & 10.8 & - & - & 0.956 & 0.500 \\
\hline $200 \mathrm{~kW}$ & 77.7 & 0.9 & 10.1 & 11.3 & - & - & 0.960 & 0.472 \\
\hline
\end{tabular}

Anode Inlet

\begin{tabular}{|l|c|c|c|c|c|c|c|c|}
\hline Power & $\mathbf{H}_{2}$ (by diff) & $\mathrm{CH}_{4}$ & $\mathbf{C O}_{2}$ & $\mathbf{C O}$ & $\mathbf{N}_{2}$ & $\mathbf{O}_{2}$ & Theta & Psi \\
\hline $80 \mathrm{~kW}$ & 79.7 & 0.9 & 18.8 & 0.6 & - & - & 0.956 & 0.969 \\
\hline $200 \mathrm{~kW}$ & 79.6 & 0.9 & 17.6 & 1.9 & - & - & 0.956 & 0.903 \\
\hline
\end{tabular}

Anode Exit

\begin{tabular}{|l|c|c|c|c|c|c|c|c|c|}
\hline Power & $\mathbf{H}_{2}$ (by diff) & $\mathrm{CH}_{4}$ & $\mathbf{C O}_{2}$ & $\mathbf{C O}$ & $\mathbf{N}_{2}$ & $\mathbf{O}_{2}$ & Theta & psi & $\mathbf{U H}_{2}$ \\
\hline $80 \mathrm{~kW}$ & 46.9 & 2.3 & 49.7 & 1.1 & - & - & 0.957 & 0.978 & 0.775 \\
\hline $200 \mathrm{~kW}$ & 49.1 & 2.2 & 44.3 & 4.4 & - & - & 0.957 & 0.910 & 0.753 \\
\hline
\end{tabular}

UTC Fuel Cells response to the gas tables indicated that that the fuel conversion and hydrogen use were as expected at 0.96 and 0.76 respectively. The CO level exiting the Low Temperature Shift Catalyst (LTSC) bed to the anode inlet had increased to 1.9 percent, per UTC Fuel Cells the typical level is 0.7 to 1.0 percent. High CO will adversely impact cell performance, particularly the end cells at the top and bottom of the CSA, because these cells are colder. To reduce the $\mathrm{CO}$ level, the steam schedule was further increased by 10 percent. 
The baseline gas analysis taken in January 2002, was performed with both the CTC GC and the UTC Fuel Cells NDIR system. Table 5 is the gas chromatograph data. Table 6 is the NDIR data. The CO level at the anode inlet had reduced to 1.3 percent as indicated in the NDIR data. Because of equilibrium, any further increase in steam flow results in diminishing returns. With that, no additional changes were made to the steam schedule.

Table 5. Gas analysis results, gas chromatograph (January 2002).

Reformer Process Exit

\begin{tabular}{|l|l|l|l|l|l|l|l|l|}
\hline Power & $\mathbf{H}_{\mathbf{2}}$ & $\mathbf{C H}_{\mathbf{4}}$ & $\mathbf{C O}_{2}$ & $\mathbf{C O}^{*}$ & $\mathbf{N}_{\mathbf{2}}$ & $\mathbf{O}_{\mathbf{2}}$ & Theta & psi \\
\hline Idle & 74.5 & 0.2 & $18^{*}$ & 7.3 & 0.0 & 0.0 & 0.992 & 0.711 \\
\hline $50 \mathrm{~kW}$ & 80.2 & 1.0 & 11.2 & 7.6 & 0.0 & 0.0 & 0.949 & 0.596 \\
\hline $80 \mathrm{~kW}$ & 78.4 & 1.1 & 12.2 & 8.3 & 0.0 & 0.0 & 0.949 & 0.595 \\
\hline $100 \mathrm{~kW}$ & 78.6 & 1.2 & 12.0 & 8.2 & 0.0 & 0.0 & 0.944 & 0.594 \\
\hline $125 \mathrm{~kW}$ & 79.4 & 1.0 & 12.2 & 7.4 & 0.0 & 0.0 & 0.951 & 0.622 \\
\hline $150 \mathrm{~kW}$ & 80.0 & 1.1 & 11.4 & 7.5 & 0.0 & 0.0 & 0.945 & 0.603 \\
\hline $175 \mathrm{~kW}$ & 79.2 & 1.2 & 11.1 & 8.5 & 0.0 & 0.0 & 0.942 & 0.566 \\
\hline $200 \mathrm{~kW}$ & 79.2 & 0.9 & 10.9 & 9.0 & 0.0 & 0.0 & 0.957 & 0.548 \\
\hline $200 \mathrm{~kW}$ & 83.9 & 0.7 & $8.4^{*}$ & 7.0 & 0.0 & 0.0 & 0.957 & 0.545 \\
\hline
\end{tabular}

\section{Anode Inlet}

\begin{tabular}{|l|c|c|c|c|c|c|c|c|}
\hline Power & $\mathbf{H}_{\mathbf{2}}$ & $\mathbf{C H}_{\mathbf{4}}$ & $\mathbf{C O}_{\mathbf{2}}$ & $\mathbf{C O}$ & $\mathbf{N}_{\mathbf{2}}$ & $\mathbf{O}_{\mathbf{2}}$ & Theta & psi \\
\hline Idle & 85.2 & 0.1 & $14.5^{*}$ & 0.2 & 0.0 & 0.0 & 0.993 & 0.986 \\
\hline $50 \mathrm{~kW}$ & 78.8 & 0.9 & 19.8 & 0.5 & 0.0 & 0.0 & 0.958 & 0.975 \\
\hline $80 \mathrm{~kW}$ & 78.4 & 1.1 & 20.3 & 0.2 & 0.0 & 0.0 & 0.949 & 0.990 \\
\hline $100 \mathrm{~kW}$ & 79.5 & 1.2 & 16.7 & $2.6^{*}$ & 0.0 & 0.0 & 0.941 & 0.865 \\
\hline $125 \mathrm{~kW}$ & 79.9 & 1.0 & 18.0 & 1.1 & 0.0 & 0.0 & 0.950 & 0.942 \\
\hline $150 \mathrm{~kW}$ & 79.1 & 1.2 & 18.6 & 1.1 & 0.0 & 0.0 & 0.943 & 0.944 \\
\hline $175 \mathrm{~kW}$ & 77.9 & 1.2 & 20.3 & 0.6 & 0.0 & 0.0 & 0.946 & 0.971 \\
\hline $200 \mathrm{~kW}$ & 74.8 & 0.7 & $23.4^{*}$ & 1.1 & 0.0 & 0.0 & 0.972 & 0.955 \\
\hline $200 \mathrm{~kW}$ & 83.3 & 0.7 & $15.3^{*}$ & 0.7 & 0.0 & 0.0 & 0.958 & 0.956 \\
\hline
\end{tabular}

\section{Anode Exit}

\begin{tabular}{|l|c|c|c|c|c|c|c|c|c|}
\hline Power & $\mathrm{H}_{2}$ & $\mathrm{CH}_{4}$ & $\mathbf{C O}_{2}$ & $\mathbf{C O}$ & $\mathbf{N}_{2}$ & $\mathbf{O}_{2}$ & Theta & psi & $\mathbf{U H}_{2}$ \\
\hline Idle & 61.4 & 0.4 & $37.8^{*}$ & 0.4 & 0.0 & 0.0 & 0.990 & 0.990 & 0.724 \\
\hline $50 \mathrm{~kW}$ & 46.8 & 2.3 & 50.5 & 0.4 & 0.0 & 0.0 & 0.957 & 0.992 & 0.763 \\
\hline $80 \mathrm{~kW}$ & 43.0 & 2.5 & 54.0 & 0.5 & 0.0 & 0.0 & 0.956 & 0.991 & 0.792 \\
\hline $100 \mathrm{~kW}$ & 63.3 & 2.3 & $34.2^{\star}$ & 0.2 & 0.0 & 0.0 & 0.937 & 0.994 & 0.555 \\
\hline $125 \mathrm{~kW}$ & 50.4 & 2.3 & 46.8 & 0.5 & 0.0 & 0.0 & 0.954 & 0.989 & 0.744 \\
\hline $150 \mathrm{~kW}$ & 46.6 & 3.0 & 49.4 & 1.0 & 0.0 & 0.0 & 0.944 & 0.980 & 0.769 \\
\hline $175 \mathrm{~kW}$ & 57.9 & 2.3 & $38.6^{\star}$ & 1.2 & 0.0 & 0.0 & 0.945 & 0.970 & 0.610 \\
\hline $200 \mathrm{~kW}$ & 40.1 & 2.2 & 51.9 & $5.8^{*}$ & 0.0 & 0.0 & 0.963 & 0.899 & 0.774 \\
\hline $200 \mathrm{~kW}$ & 58.0 & 1.7 & $38.6^{*}$ & 1.7 & 0.0 & 0.0 & 0.960 & 0.958 & 0.723 \\
\hline
\end{tabular}


Table 6. Gas analysis results, field anarad (January 2002).

Reformer Process Exit

\begin{tabular}{|l|c|c|c|c|c|c|c|l|}
\hline Power & $\mathbf{H}_{2}$ (by diff) & $\mathbf{C H}_{4}$ & $\mathbf{C O}_{2}$ & $\mathbf{C O}$ & $\mathbf{N}_{2}$ & $\mathbf{O}_{2}$ & Theta & psi \\
\hline Idle & 77.4 & 0.2 & 11.4 & 11.0 & - & - & 0.991 & 0.509 \\
\hline $50 \mathrm{~kW}$ & 76.1 & 1.0 & 12.5 & 10.4 & - & - & 0.958 & 0.546 \\
\hline $80 \mathrm{~kW}$ & 76.3 & 0.7 & 13.2 & 9.8 & - & - & 0.970 & 0.574 \\
\hline $100 \mathrm{~kW}$ & 76.6 & 1.0 & 12.2 & 10.2 & - & - & 0.957 & 0.545 \\
\hline $125 \mathrm{~kW}$ & 76.8 & 0.9 & 12.6 & 9.7 & - & - & 0.961 & 0.565 \\
\hline $150 \mathrm{~kW}$ & 67.8 & 1.0 & 11.8 & $19.4^{*}$ & - & - & 0.969 & 0.378 \\
\hline $175 \mathrm{~kW}$ & 77.1 & 0.9 & 11.4 & 10.6 & - & - & 0.961 & 0.518 \\
\hline $200 \mathrm{~kW}$ & 76.5 & 0.7 & 11.3 & 11.5 & - & - & 0.970 & 0.496 \\
\hline $200 \mathrm{~kW}$ & 76.5 & 0.7 & 11.4 & 11.4 & - & - & 0.970 & 0.500 \\
\hline
\end{tabular}

Anode Inlet

\begin{tabular}{|l|c|c|c|c|c|c|c|c|}
\hline Power & $\mathrm{H}_{2}$ (by diff) & $\mathrm{CH}_{4}$ & $\mathrm{CO}_{2}$ & $\mathbf{C O}$ & $\mathrm{N}_{2}$ & $\mathrm{O}_{2}$ & Theta & psi \\
\hline Idle & 79.6 & 0.2 & 19.8 & 0.4 & - & - & 0.990 & 0.980 \\
\hline $50 \mathrm{~kW}$ & 79.2 & 0.9 & 19.5 & 0.4 & - & - & 0.957 & 0.980 \\
\hline $80 \mathrm{~kW}$ & 78.8 & 1.2 & 19.5 & 0.5 & - & - & 0.943 & 0.975 \\
\hline $100 \mathrm{~kW}$ & 78.8 & 1.0 & 19.7 & 0.5 & - & - & 0.953 & 0.975 \\
\hline $125 \mathrm{~kW}$ & 78.5 & 0.9 & 20.0 & 0.6 & - & - & 0.958 & 0.971 \\
\hline $150 \mathrm{~kW}$ & 79.0 & 0.9 & 19.4 & 0.7 & - & - & 0.957 & 0.965 \\
\hline $175 \mathrm{~kW}$ & 79.3 & 0.9 & 18.8 & 1.0 & - & - & 0.957 & 0.949 \\
\hline $200 \mathrm{~kW}$ & 79.1 & 0.6 & 18.9 & 1.4 & - & - & 0.971 & 0.931 \\
\hline $200 \mathrm{~kW}$ & 79.0 & 0.7 & 19.0 & 1.3 & - & - & 0.967 & 0.936 \\
\hline
\end{tabular}

Anode Exit

\begin{tabular}{|l|c|c|c|c|c|c|c|c|c|}
\hline Power & $\mathrm{H}_{2}$ (by diff) & $\mathrm{CH}_{4}$ & $\mathrm{CO}_{2}$ & $\mathbf{C O}$ & $\mathrm{N}_{2}$ & $\mathrm{O}_{2}$ & Theta & psi & $\mathrm{UH}_{2}$ \\
\hline Idle & 51.7 & 0.5 & 47.2 & 0.6 & - & - & 0.990 & 0.987 & 0.726 \\
\hline $50 \mathrm{~kW}$ & 45.7 & 2.3 & 51.1 & 0.9 & - & - & 0.958 & 0.983 & 0.779 \\
\hline $80 \mathrm{~kW}$ & 48.8 & 1.8 & 48.5 & 0.9 & - & - & 0.965 & 0.982 & 0.744 \\
\hline $100 \mathrm{~kW}$ & 47.6 & 2.5 & 49.0 & 0.9 & - & - & 0.952 & 0.982 & 0.756 \\
\hline $125 \mathrm{~kW}$ & 47.0 & 2.3 & 49.6 & 1.1 & - & - & 0.957 & 0.978 & 0.757 \\
\hline $150 \mathrm{~kW}$ & 46.8 & 2.7 & 48.8 & 1.7 & - & - & 0.949 & 0.966 & 0.766 \\
\hline $175 \mathrm{~kW}$ & 46.9 & 2.5 & 48.1 & 2.5 & - & - & 0.953 & 0.951 & 0.769 \\
\hline $200 \mathrm{~kW}$ & 48.1 & 1.8 & 46.8 & 3.3 & - & - & 0.965 & 0.934 & 0.755 \\
\hline $200 \mathrm{~kW}$ & 46.6 & 1.8 & 48.1 & 3.5 & - & - & 0.966 & 0.932 & 0.768 \\
\hline * error in readings & & & & & & & \\
\hline
\end{tabular}

The reformer, as defined by the gas analysis, shows no deterioration since the initial operation of the power plant. Per UTC Fuel Cells, this trend is typical of PC25 fleet experience. The low temperature shift catalyst shows some indications of diminished capability. UTC Fuel Cells claims that this is not unusual in the PC25 fleet although the change in 9194 appears to be higher than expected. Periodic gas analysis should be performed to continue the evaluation of the LTSC performance over time. 
The fuel cell stack within the system as tested has accumulated 22,000 load hours as of 4-01-2003. Per UTC Fuel Cells, stack performance throughout the operation has been within the expected band for a 32 substack cell stack assembly. Figure 7, supplied by UTC Fuel Cells, identifies the estimated total system voltage with no shutdowns as compared with 6 to 8 shutdowns per year.

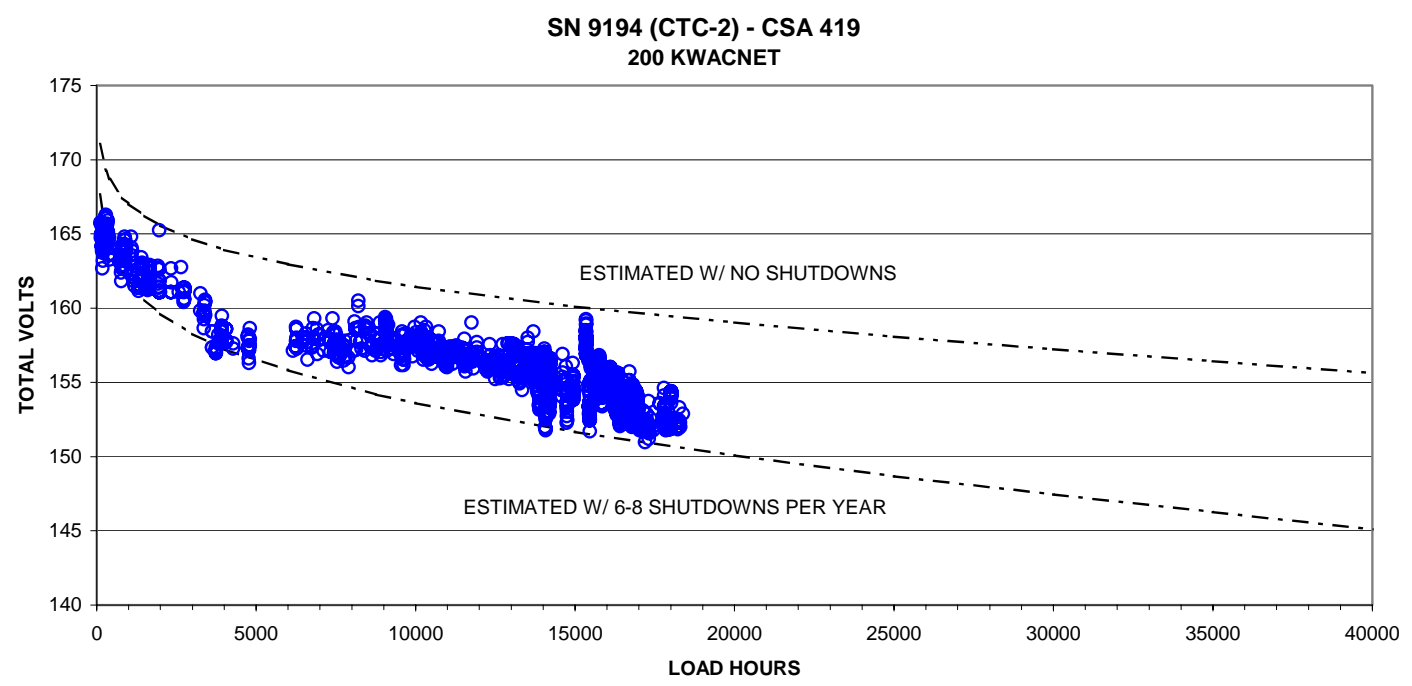

Figure 7. Fuel Cell Power Plant 9194 stack voltages at 200 kW power output.

Power Plant 9194, substack voltage profile, shown in Figure 8,identifies substack voltages over the operation of the system. As a whole, there are no significant issues with the voltage profile. The higher than expected $\mathrm{CO}$ concentrations through the stack may account for the slight drop at the end sub modules. The trend of the voltage profile looks essentially the same at 18000 hours as it did at 2000 hours.

POWER PLANT 9194 (CSA 419)

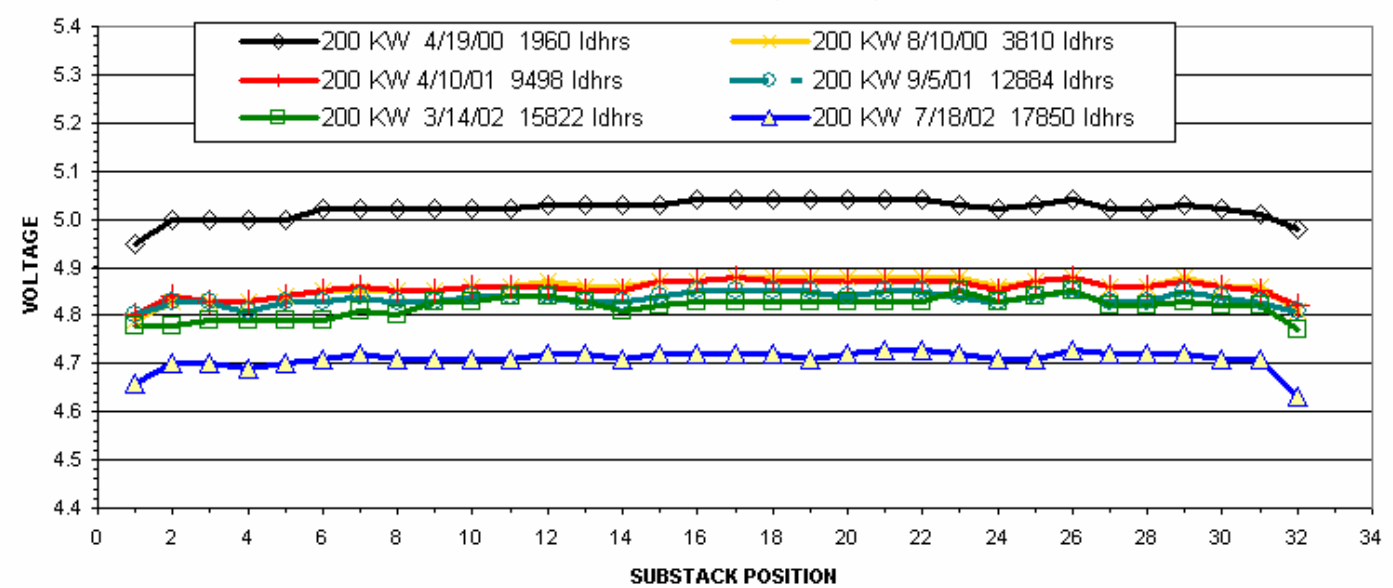

Figure 8. Fuel Cell Power Plant 9194 sub-stack voltage profile. 
An outdoor fan cooled condenser maintains the appropriate fuel cell system temperature for the system requirements. This cooling system is comprised of four low speed, low noise fan motors that operate on a temperature signal. Noise recordings were documented using a digital CEL-328 sound meter at five positions around the cooling module at a distance of $30 \mathrm{ft}$ away. The noise level produced by the cooling module fans was no more than 57 decibels, which is less than normal voice conversation level $(70 \mathrm{~dB})$. The start up noise was only slightly higher at $61 \mathrm{~dB}$. The background noise measured at the same points was $45 \mathrm{~dB}$. The new cooling module was significantly quieter than the past systems and is lower than normal voice conversation level that is typically at $70 \mathrm{~dB}$.

\section{Heat Recovery BT003}

\section{Objective}

The purpose of the PC25C Fuel Cell Power Plant heat recovery testing was to document the available heat recovery capability from the low and high-grade heat recovery customer interfaces of the PC25C. Additionally, the customer side pressure drop through each heat recovery heat exchanger was characterized. This testing assisted in the knowledge source for future PC25C designs using the combined heat and power application. Obtaining the proper heat recovery possible at varying power levels is imperative to design applications where the recovered heat is being used to replace other thermal supplies. This information was used during the installation of a multi-system installation at the U.S. Postal Service facility in Anchorage, AK.

\section{Activity}

Additional heat recovery testing was initiated during May of 2002. At the time of this testing the power plant had operated for approximately 17,000 load hours. CTC Installed a new low range flow meter in the thermal load test stand to improve the system accuracy below $25 \mathrm{gpm}$. Based on the past review of the test results it was concluded that the high range flow meter was not sufficiently accurate over the entire flow range of 8 to $130 \mathrm{gpm}$. The low range flow meter provided results more accurate results to define the actual thermal output of the system.

\section{High Grade Heat Exchanger Testing}

This phase of thermal testing used three different customer return temperatures and three flow rates with the two flow meters available (Table 7). 
Table 7. High grade heat exchanger test conditions.

\begin{tabular}{|c|c|c|c|c|}
\hline \multicolumn{4}{|c|}{ High Grade Heat Exchanger Testing (Hex 490) @ 200 kW } \\
\hline \multirow{2}{*}{$\begin{array}{c}\text { Customer Side Return } \\
\text { Temp ( }{ }^{\circ} \text { F) }\end{array}$} & \multicolumn{3}{|c|}{ Customer Side Flow Rate (gpm) } \\
\cline { 2 - 5 } & \multicolumn{2}{|c|}{ Low flow meter } & \multicolumn{2}{c|}{ High flow meter } \\
\hline 150 & 15 & 25 & 25 & 50 \\
\hline 200 & 15 & 25 & 25 & 50 \\
\hline 250 & 15 & 25 & 25 & 50 \\
\hline
\end{tabular}

The test conditions allowed the flows to overlap at $25 \mathrm{gpm}$ to compare the high flow and low flow meter information. Figure 9 shows the results of the highgrade heat exchanger testing as supplied by UTC Fuel Cells.

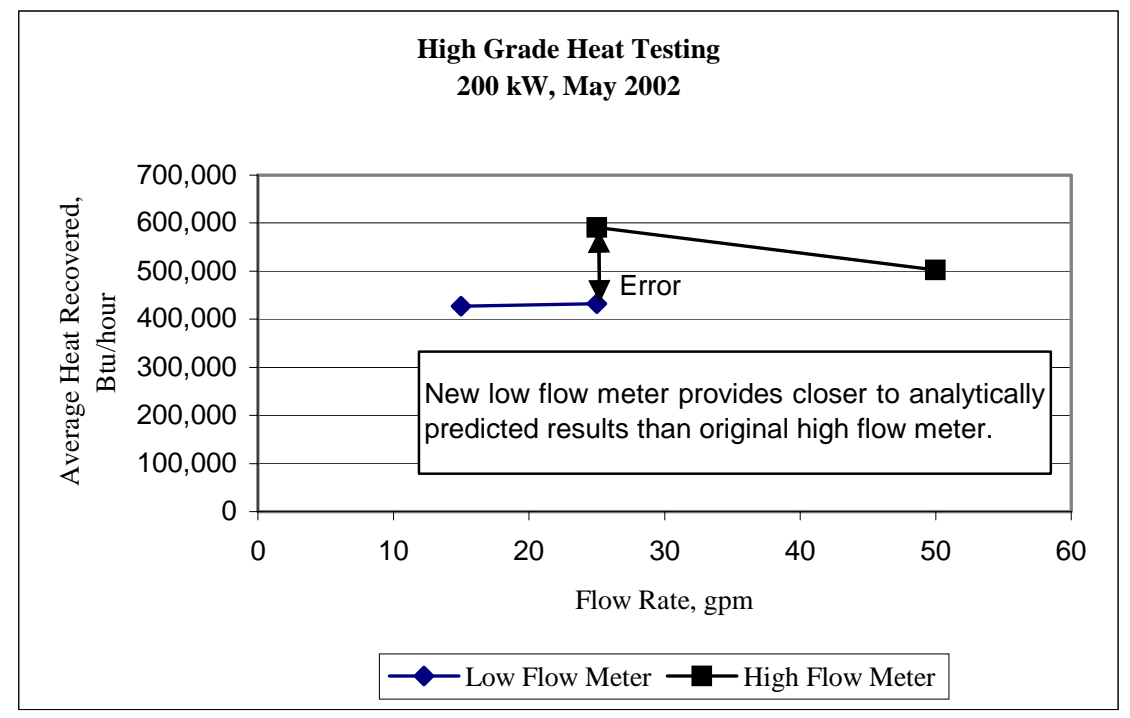

Figure 9. High-grade heat recovery, low vs. high range flow meter.

\section{Comparison}

The available heat per design should be in the range of $300,000 \mathrm{Btu} / \mathrm{hr}$ to $350,000 \mathrm{Btu} / \mathrm{hr}$ during the initial operation of a 32-substack PC25C power plant at beginning of life. As the power plant ages, additional high-grade heat is available because of the increasing inefficiencies of the system. The approximate $425,000 \mathrm{Btu} /$ hour of heat recorded by the low-flow meter at $25 \mathrm{gpm}$ agrees with past reported levels of high-grade heat. The near 600,000 Btu/hour result recorded by the high-flow meter at 25 gpm was inaccurate because of the use at the very low extremes of the meters capabilities. 


\section{Low Grade Heat Recovery}

This phase of thermal testing used three different customer return temperatures and three flow rates with the two flow meters available. This is demonstrated in Table 8.

Table 8. Low grade heat exchanger test conditions.

\begin{tabular}{|c|c|c|c|c|}
\hline \multicolumn{4}{|c|}{ Low Grade Heat Exchanger Testing (Hex 880) @ 200 kW } \\
\hline $\begin{array}{c}\text { Customer Side Return } \\
\text { Temp ( }{ }^{\circ} \text { F) }\end{array}$ & \multicolumn{4}{c|}{ Customer Side Flow Rate (gpm) } \\
\cline { 2 - 5 } & \multicolumn{2}{|c|}{ Low Flow Meter } & \multicolumn{2}{c|}{ High Flow Meter } \\
\hline 80 & 10 & 25 & 25 & 50 \\
\hline 120 & 10 & 25 & 25 & 50 \\
\hline 160 & 10 & 25 & 25 & 50 \\
\hline
\end{tabular}

The results of the new low-grade heat exchanger testing are shown in Figure 10 for the $25 \mathrm{gpm}$ customer flow case. Heat recovery is plotted versus customer water temperature into the fuel cell low-grade heat exchanger. As with the highgrade test results, the low range flow meter provided results with increased accuracy.

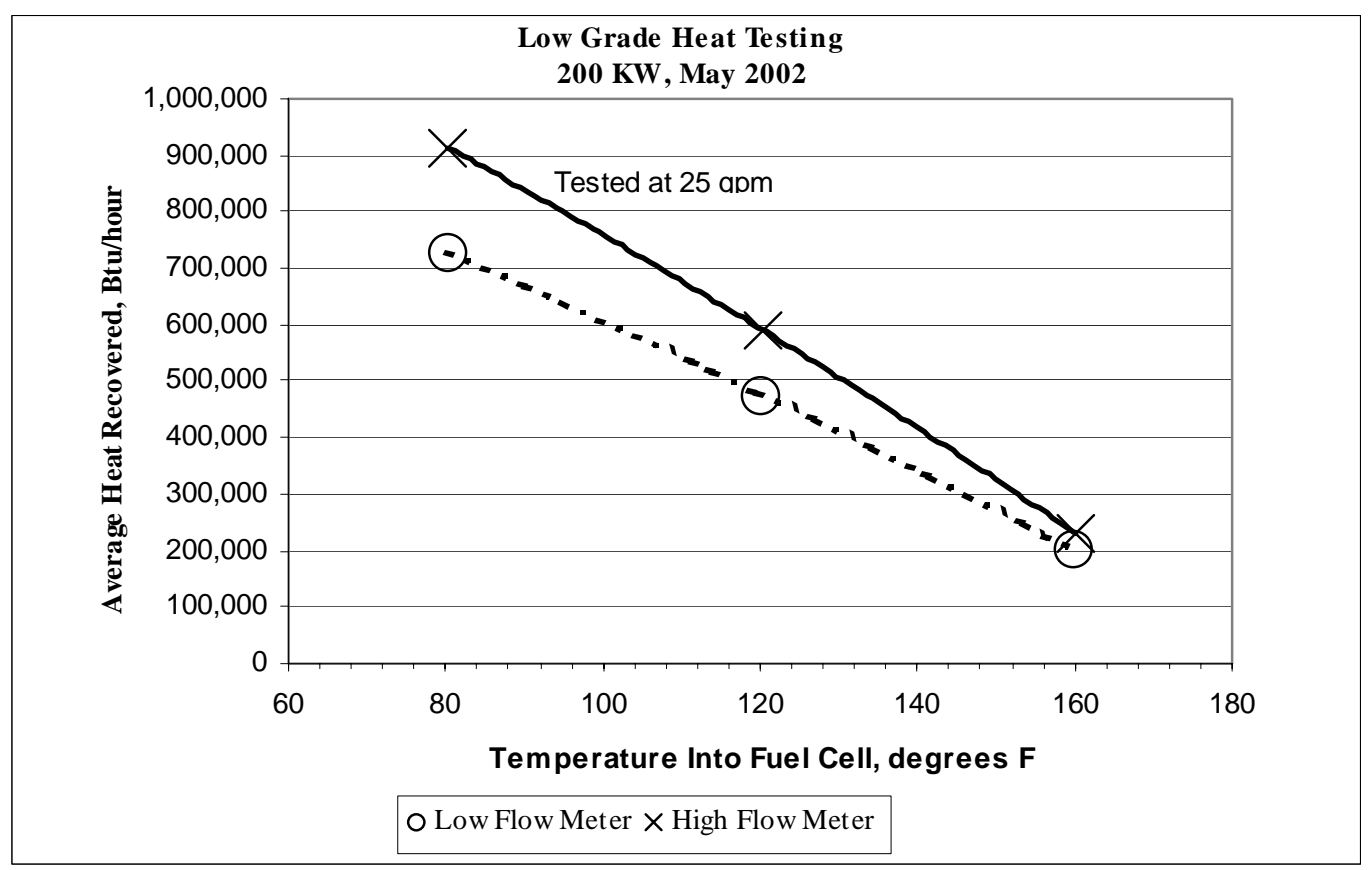

Figure 10. Low-grade heat recovery, flow meter comparison (@25 gpm). 


\section{Conclusion}

As a result of the $C T C$ testing the heat recovery characteristics have been updated in the latest edition of the PC25 Fuel Cell Power Plant Manual. All data from the various flows are cataloged in the BT003, Thermal Recovery, data archive. The high flow meter accuracy at $50 \mathrm{gpm}$ is appropriate and confirms the available heat recovery from the system.

At initial use of a PC25C power plant, the amount of total recoverable heat is predicted to be approximately 725,000 Btu/hour with the high-grade heat contribution of approximately 275,000 Btu/hour (Figure 11).

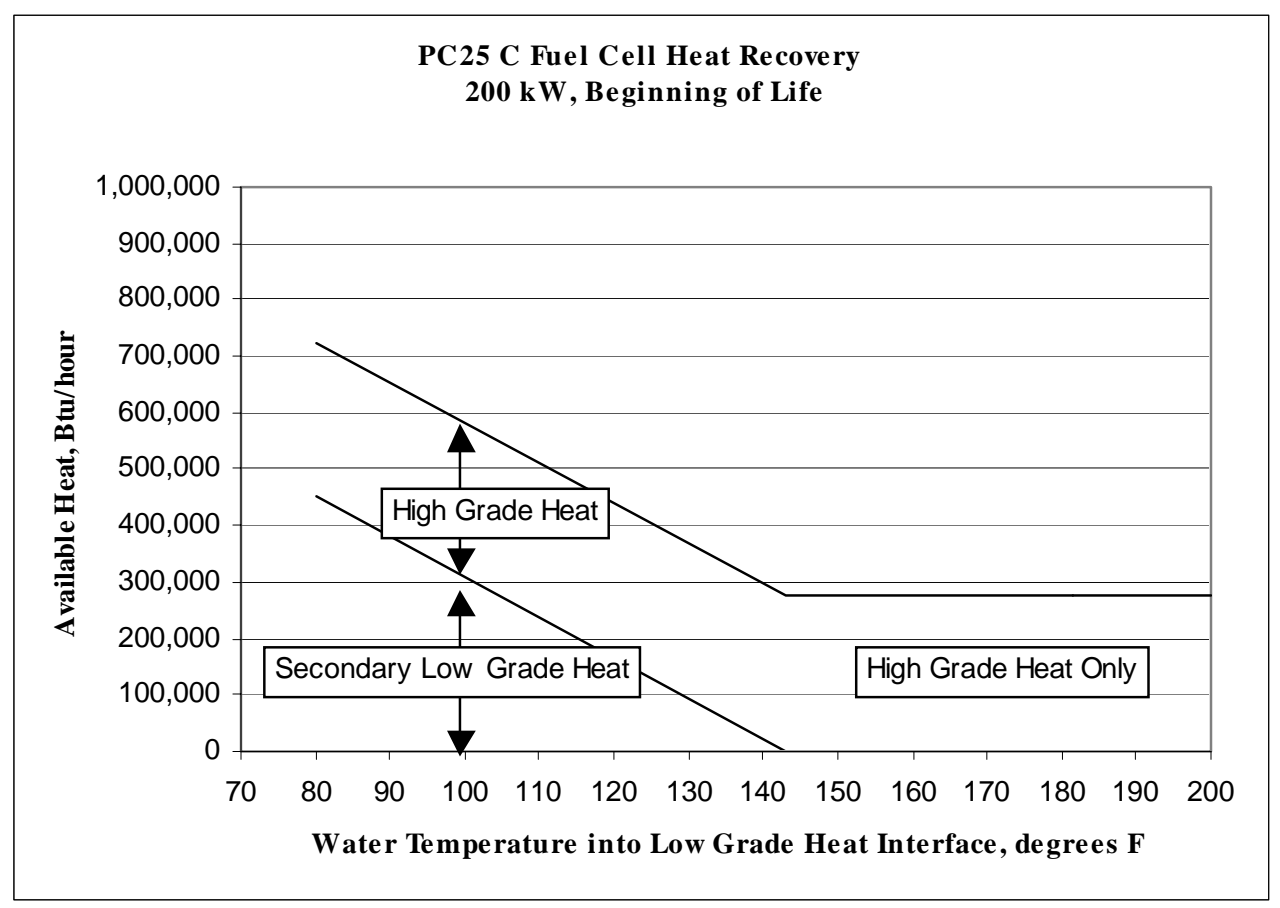

Figure 11. Available PC25 heat recovery, 200 kW, beginning of life.

The data assume a customer side flow rate of $20 \mathrm{gpm}$ or higher into both the low and high grade heat exchangers. It should be noted that the average high-grade heat can vary by $+/-100,000 \mathrm{Btu} /$ hour due to the impact of internal feed water operation, which has a cooling effect on the cell stack cooling system. Available secondary low-grade heat will increase as the use of high-grade heat is diminished. The amount of secondary low-grade heat is a function of the customer water temperature into the low-grade heat exchanger as noted on the x-axis of Figure 12. 
In Figure 9, under the condition that no high-grade heat is being recovered, the upper diagonal line can be extrapolated to the $\mathrm{x}$-axis to estimate the available low-grade interface heat recovery at inlet temperatures exceeding $143^{\circ} \mathrm{F}$. Approaching the end of power plant life the amount of total recoverable heat is predicted to be approximately $925,000 \mathrm{Btu} /$ hour with the high-grade heat contribution of approximately 475,000 Btu/hour (Figure 12).

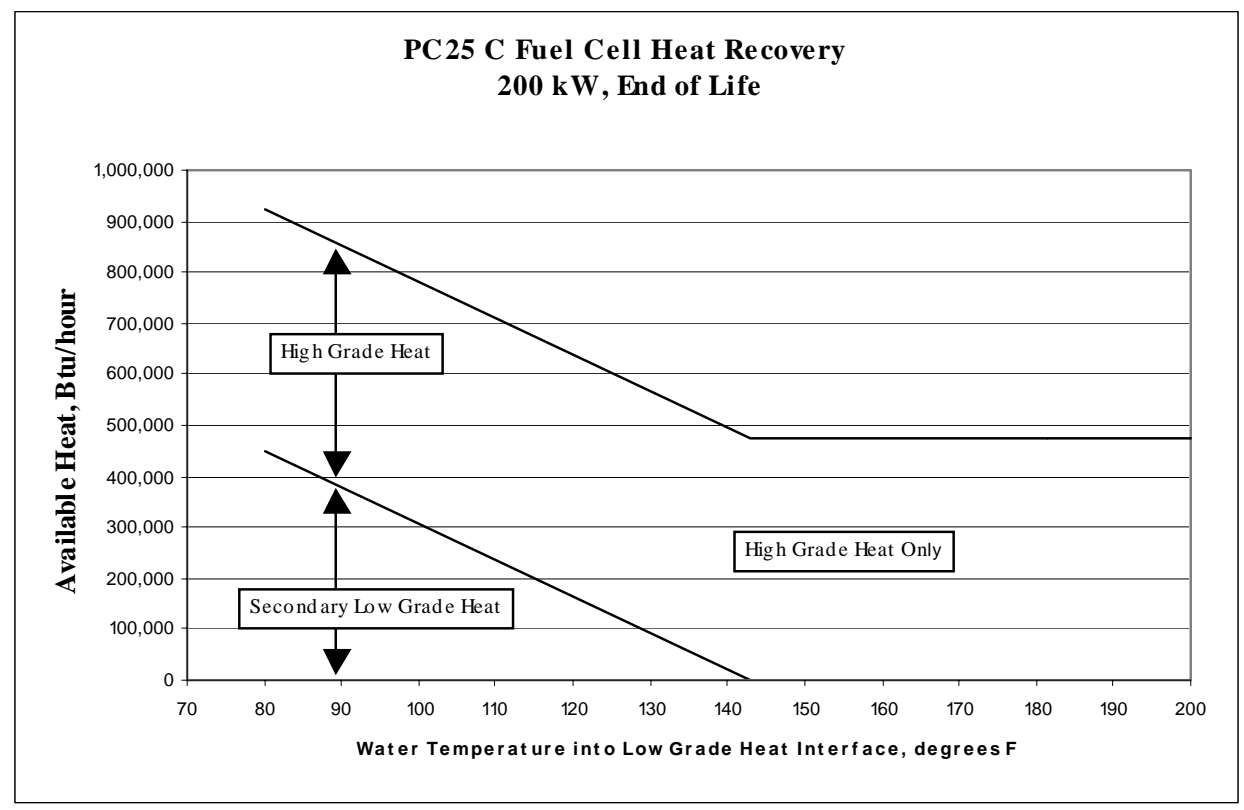

Figure 12. Available PC25 heat recovery, 200 kW, end of life.

\section{Grid Independent BT005A}

\section{Objective}

Test the capability of the power plant to handle transient power demands created by changing electrical load conditions. The system response was monitored with the FCTec Control and Data Acquisition System (CDAQ), and a Dranetz disturbance Analyzer.

\section{Activity}

This test used combinations of both the resistive and motor load banks in a grid independent mode. The test was executed in multiple stages. In each trial, the power plant was loaded with a nominal steady-state electrical load (combinations of resistive and inductive loads). Various motor loads ranging between $5 \mathrm{hp}$ and $50 \mathrm{hp}$ was added to the fuel cell power requirement, and the power plant response monitored. The motors were connected to various systems including centrifugal fans and pumps. Before, during, and after each load addition 
test, system voltage, current, wattage, and power quality were recorded along with the nominal ratings of the loads.

\section{Conclusion}

This measurement of the fuel cells power plant's ability to manage increasing loads was performed both under the original Modification 1 testing as well as under the Modification 2 testing phase. All data and graphical information were transmitted to ERDC/CERL and UTC Fuel Cells on completion of the tests. The second operation of the grid independent capabilities of the PC25C allowed for a comparison of new power plant capabilities verses a system approaching 22,000 hours of use. Figure 13 identifies the voltage sag indicative of the aging stack. As the power increase is greater, the voltage sag from new stack conditions to half life stack conditions increases proportionally. The system capabilities decreased from $190 \mathrm{~kW}$ step ability to $160 \mathrm{~kW}$ step capability.

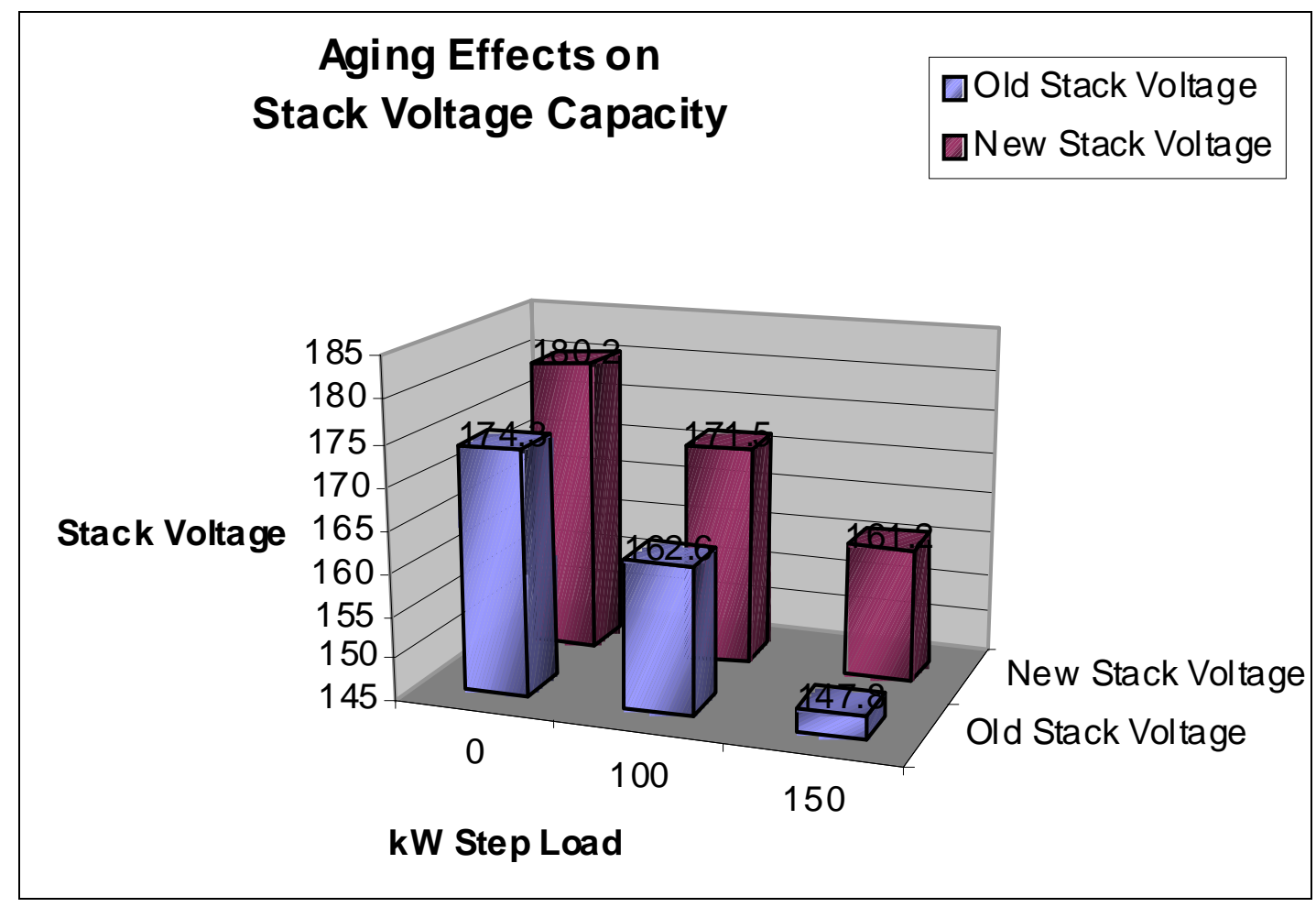

Figure 13. Aging effects on stack voltage under load.

Reviewing the stack Voltage and Current (VI) curve with out respect of parasitic power also indicates the capability reduction. Figure 14 identifies the original stack VI curve with that of the testing performed at 22,000 hours. As the current increases the voltage is now sagging to a point approaching 145 volts. 


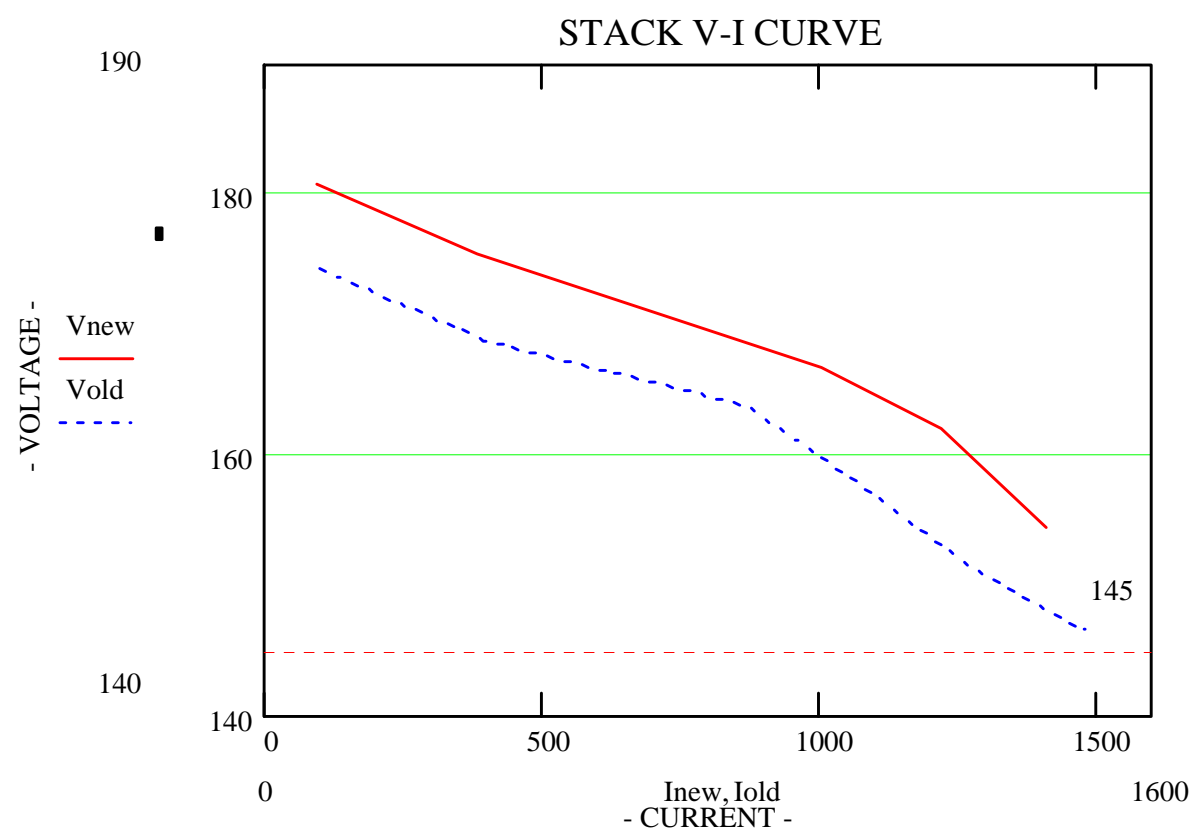

Figure 14. Aging effects on the stack VI curve.

\section{BT005E Grid Independent (VC/APS)}

\section{Objective}

Define and evaluate requirements to reduce valve cycling during steady state operation. This transient testing will increase the transient capability of the power plant. The final changes will improve valve life, reliability, and life cycle cost. This will be performed by evaluating the feasibility of replacing the existing Cooling Module fan(s) electromechanical control with a Variable Speed Drive (VSD) control.

\section{Activity}

New valve actuators were installed to update the power plant to current bill of materials standards. A VSD unit was located within the power plant Electrical Control System to evaluate remote monitoring and control of the Cooling Module.

This change in location required electrical modifications (hardware and wiring) and software reprogramming to the controller to provide for both external monitoring of the Cooling Module glycol exit temperature and generating the necessary VSD control signals. Initial operation of this configuration resulted in several motor failures and respective fuse clearing. Preliminary investigation 
identified possible common-mode currents as the failure mechanism and a shielded power cable as a potential corrective measure. This power driven shield is designed to minimize common-mode currents, by providing a low-impedance path to ground for draining ground currents.

The shielded power cable was next installed, replacing the existing power plant / cooling module power cable and testing resumed. Unfortunately, several additional motor failures were experienced, thereby indicating a failure source other than common-mode currents. Further motor investigation and data analysis revealed the presence of significantly large voltage spikes at the motor terminals. These voltage spikes were being generated by the VSD transistorized inverter in conjunction with the long motor cable length (100 ft), and generate a phenomenon called "voltage amplification." A recognized industry approach to reducing these peak voltages to a benign sinusoidal waveform is the insertion of a "Motor Protection Filter" at the VSD output. Consequently, this type of power filter was ordered, installed and testing resumed.

Specifically, two "Motor Protection Filters" manufactured by Trans-Coil Inc. (TCI) and MTE were procured by UTC Fuel Cells and, installed by CTC. The systems were then evaluated relative to peak voltage levels monitored at the Cooling Module fan/motors. The observed voltage spikes at the motor for each filter were significantly reduced by approximately 50 percent, well below the motor manufacturers specification, and no further premature motor failures were experienced. As part of this evaluation, the new power cable (ECS-to Cooling Module) shield was disconnected to determine its effectiveness relative to incorporation of the filter. These tests concluded that this shielded power cable offered no measurable benefits, and therefore will not replace the existing power cable.

\section{Conclusion}

After UTC Fuel Cells reviewed the test data, the TCI filter was selected, primarily due to superior thermal operating characteristics. The MTE filter measured operating temperature was approximately $70^{\circ} \mathrm{F}$ above the TCI unit $\left(175^{\circ} \mathrm{F}\right.$ vs. $\left.105^{\circ} \mathrm{F}\right)$, and therefore perceived as failure prone when located in high-ambient temperature environments. The power plant / Cooling Module continues to operate with no motor failures since installation of the TCI filter and removal of the power cable shield. Due to this testing, a UTC Fuel Cells engineering design change was implemented to integrate the selected TCI filter with the VSD800 drive in retrofitted applications. 


\section{BT005F Grid Independent (PT)}

\section{Objective}

To optimize the reformer temperature schedule, improve power plant efficiency and extend reformer tube life. A reduction in operating temperature of the reformer system will provide efficiency during steady state operation.

\section{Activity}

Two thermocouples were installed into the reformer burner cavity. These thermocouples duplicate the current reformer control thermocouples as part of the logic that monitors presence of the flame for compliance with the current code requirement of greater than $1400^{\circ} \mathrm{F}$ in the burner cavity.

\section{Conclusion}

Operating at $150 \mathrm{~kW}$, upon a shutdown event, the temperatures within the reformer drop below $1400^{\circ} \mathrm{F}$ within 5 minutes as indicated in Figure 15. After that point, the temperatures slowly sag until the system is restarted. No change in reformer temperatures were made because of the dramatic drop in temperature within the system. Reducing the system operating temperature would have had a detrimental effect on the ability of the system ability to respond to transients.

\section{Water Quality BT008}

\section{Objective}

The purpose of the Water Quality testing was to assess the water quality within the fuel cell power plant. Water quality data were taken on a scheduled basis at various points around the power plant including:

- Thermal Management CSA cooling loop (HV431)

- feedwater / DMN450 (HV453)

- water storage tank (TNK450)

- site make-up water. 


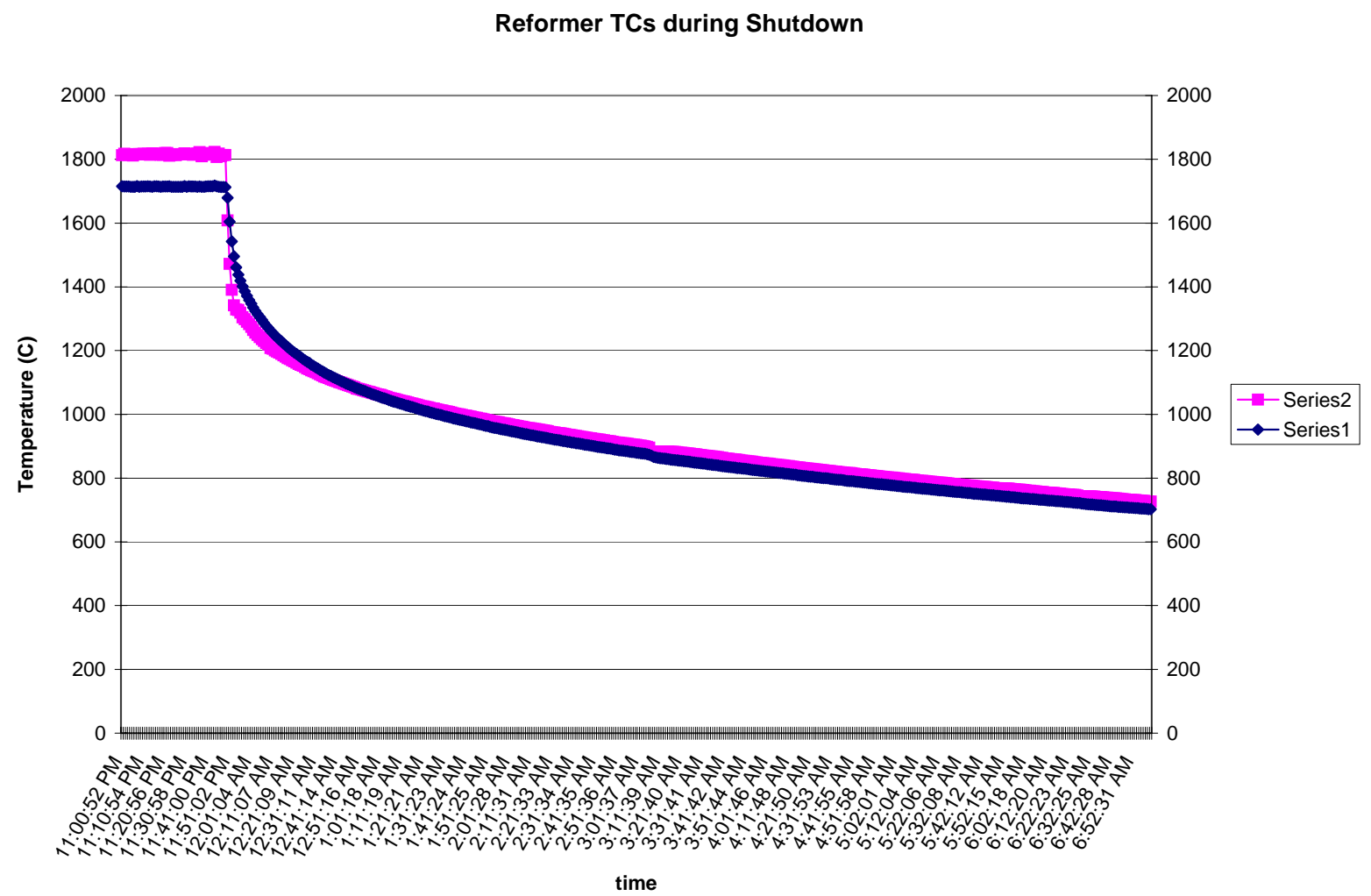

Figure 15. Nineteen tube reformer shutdown temperature profile.

\section{Activity}

Fuel cell reliability and long term operation is often dependent on water quality. Previous fuel cell stack failures have been attributed to poor water quality, causing deposit build-up at essential cooling locations throughout the fuel cell. Improvements on input water quality and on board water conditioning systems will provide enhanced system reliability. The water quality within the PC25C fuel cell system was evaluated and compared to previous data collected to determine degradation of water quality and frequency of resin change-out.

Water samples were analyzed using typical water analysis field instruments for the following items:

- $\mathrm{pH}$

- conductivity

- turbidity

- dissolved oxygen.

To further define water chemistry, water samples were also periodically analyzed using laboratory instruments. In addition to $\mathrm{pH}$, conductivity, turbidity 
and dissolved oxygen measurements, concentrations of the following we also documented:

- total suspended and dissolved solids

- total organic carbon

- standard plate count (bacteria)

- silica, chlorine, phosphates, nitrites, sulfates, iron, copper, calcium, sodium and magnesium.

\section{Conclusion}

Bad water chemistry within the CSA cooling loop can cause the build-up of deposits at critical locations in the CSA coolers, which can lead to restricted cooling flow, high cell temperatures, and potentially stack failure. It is therefore imperative that water quality within (and provided to) the Thermal Management System (TMS) be maintained.

The Water Treatment System (WTS) within the PC25C treats condensate removed from the process exhaust streams in the condenser as well as makeup water required during low power operation. Dissolved carbon dioxide is removed from the condensate via a degasifier column prior to entering the storage water tank. Water from the water tank is circulated through $2 \mathrm{cu} f \mathrm{ft}$ of activated charcoal to remove organic materials and $8 \mathrm{cu} \mathrm{ft}$ demineralizer resin to deionize the water. Periodically some of this deionized water provides feedwater to the CSA cooling loop to make up for the FPS process steam and blow down requirements.

In general the PC25 field instrument analysis results agreed with the results from the laboratory instruments in both level and trend when compared on a yearly basis (Table 9). The lab equipment demonstrated higher levels of $\mathrm{pH}$ and dissolved oxygen at most locations relative to the field instruments. Both types of equipment showed the conductivity level expected for the PC25. It was also expected that feedwater conductivity would be lower than CSA cooling loop conductivity. Turbidity was not compared since the instruments are calibrated for different units

Table 9. Water quality comparison PC25C Power Plant 9194.

\begin{tabular}{|l|c|c|c|c|c|c|c|}
\hline & \multicolumn{2}{|c|}{$\begin{array}{c}\text { Analysis } \\
\text { Instrument }\end{array}$} & \multicolumn{2}{|c|}{$\begin{array}{c}\text { Conductivity } \\
\text { Us }\end{array}$} & \multicolumn{2}{c|}{$\mathbf{p H}$} & \multicolumn{2}{c|}{$\begin{array}{c}\text { Dissolved } \\
\text { Oxygen }\end{array}$} \\
\hline & Location & $\mathbf{2 0 0 0}$ & $\mathbf{2 0 0 2}$ & $\mathbf{2 0 0 0}$ & $\mathbf{2 0 0 2}$ & $\mathbf{2 0 0 0}$ & $\mathbf{2 0 0 2}$ \\
\hline Feedwater & Field & 0.12 & 0.17 & 5.90 & 6.46 & 4.30 & 5.20 \\
\hline Feedwater & Lab & 0.37 & 0.36 & 6.37 & 6.53 & 4.35 & 6.47 \\
\hline Site make-up water & Field & 1.01 & 2.72 & 5.39 & 5.30 & 5.92 & 6.20 \\
\hline Site make-up water & Lab & 0.85 & 2.25 & 5.68 & 5.55 & 6.48 & 6.63 \\
\hline
\end{tabular}




\begin{tabular}{|l|c|c|c|c|c|c|c|}
\hline & $\begin{array}{c}\text { Analysis } \\
\text { Instrument }\end{array}$ & \multicolumn{2}{|c|}{$\begin{array}{c}\text { Conductivity } \\
\text { Us }\end{array}$} & \multicolumn{2}{c|}{ pH } & \multicolumn{2}{c|}{$\begin{array}{c}\text { Dissolved } \\
\text { Oxygen }\end{array}$} \\
\hline & Location & $\mathbf{2 0 0 0}$ & $\mathbf{2 0 0 2}$ & $\mathbf{2 0 0 0}$ & $\mathbf{2 0 0 2}$ & $\mathbf{2 0 0 0}$ & $\mathbf{2 0 0 2}$ \\
\hline CSA cooling loop & Field & 0.25 & 0.24 & 5.85 & 5.65 & 3.58 & 3.60 \\
\hline CSA cooling loop & Lab & 0.27 & 0.47 & 6.09 & 5.77 & 3.95 & 4.92 \\
\hline Water tank & Field & 20.9 & 7.64 & 5.42 & 4.85 & 4.42 & 5.60 \\
\hline Water tank & Lab & 18.78 & 6.80 & 5.69 & 5.08 & 4.55 & 6.32 \\
\hline
\end{tabular}

The average readings from Table 9 are generally typical of the PC25 fleet experience.

\section{Modification 3 Activities}

\section{Objective}

National Defense Center for Environmental Excellence (NDCEE), operated by $C T C$, developed and validated residential scale fuel cell standardized evaluation test protocols suitable for independent assessments of the applicability of individual fuel cell products manufactured by the fuel cell community. Sub-tasks completed within this activity included:

NDCEE surveyed fuel cell developers to determine the size, pertinent features, cost, and availability timeframe of existing and/or planned commercial products in the $1 \mathrm{~kW}$ to $30 \mathrm{~kW}$ range. NDCEE surveyed the Fuel Cell Developers to obtain the referenced survey information and identify the developers testing needs and the DOD FCTec testing capabilities. Plug Power was the only supplier capable of providing a system to meet the commercial needs of a natural gas fuel powered fuel cell system.

NDCEE consulted with the existing fuel cell related codes and standards committees and organizations to ensure compatibility and approval of code agencies. NDCEE's focus within this task will be concentrated on the following code areas: ANSI Z.21.83, NFPA 853, NFPA 70 Article 692, ASME PTC 50, and IEEE $\mathrm{P} 1547$.

NDCEE consulted with the National Rural of Electric Cooperation Associate (NRECA) to determine needs related to the assessment of fuel cell technology for their individual applications. Attendance and participation at the NRECA quarterly fuel cell user's group meeting allow for the review of the military and fuel cell user community application needs (e.g., telecommunication, equipment maintenance, laundry, restaurant and clinical facilities). Attendees at these 
meetings typically included members from the DOD, DOE, Fuel Cell Developers and Fuel Cell Commercial and Industrial End Users. Information collected from these meeting was used in the completion of the development of the Fuel Cell Evaluation Test Protocol.

The background research, communication and evaluation of the fuel cell systems and users needs resulted in the development of a standardized Fuel Cell Evaluation Test Protocol for residential sized fuel cell systems. These preliminary Test Protocols are to be used to support the validation tasks of residential sized fuel cell power plants within the DOD FCTec.

\section{Activities}

The individual test protocols referenced within the Appendixes of this document were developed to provide the guidelines, strategies, specifications, and concepts to ensure consistent testing strategies for all residential sized fuel cell power plants tested within FCTec.

Details of the guidelines, strategies, specifications, and concepts of each test protocol can be reviewed in each of the appendices referenced. A brief overview of the created test protocols follows.

\section{Peak Load Shutdown Test}

The objective of the Peak Load Shutdown Test is to determine the peak load supply power of the fuel cell being evaluated for both constant and changing electrical loads. Primary evaluation shall concentrate on the fuel cell's ability to supply power without the complicating factors of large inductive transients and large impulse current. Initial testing shall consist of various levels of resistive loading. Appendix J gives further details.

\section{Sustained Load Test}

The objective of the Sustained Load Test is to determine the maximum sustained load capable from the fuel cell power plant that is being evaluated for both constant and changing electrical loads. Primary evaluation concentrates on the fuel cell's ability to supply power without the complicating factors of large inductive transients and large impulse currents. Initial testing shall consist of various levels of resistive loading. Appendix K gives further details. 


\section{Sustained Load Step Test}

The objective of the Sustained Load Step Test is to determine the fuel cell power plant capabilities of operating with impulse load transitions, up to and including 100 percent of the Sustained Load that was determined during the Sustained Load Test. Primary evaluation shall concentrate on the fuel cell's ability to supply power without the complicating factors of large inductive transients and large impulse currents. Initial testing shall consist of various levels of resistive loading. Appendix L gives further details.

\section{Overload Test}

The objective of the Overload Test is to determine the fuel cell power plant's capability of operating with impulse transients up to 200 percent of the sustained load capacity. Primary evaluation shall concentrate on the fuel cell's ability to supply power without the complicating factors of large inductive transients and large impulse currents. Initial testing shall consist of various levels of resistive loading. Appendix M gives further details.

\section{Residential Profile Test}

The objective of the Residential Profile Test is to verify the fuel cell power plant's capability of operating in a residential setting, over a 5-day period. In this test, a profile will be established, and residential electrical appliances will be used to serve as the load. Loads and load changes shall be automated so that each fuel cell power plant being tested is subjected to the same load pattern. Appendix $\mathrm{N}$ gives further details.

\section{Residential Profile Test-Temperature and Humidity}

The objective of the Residential Profile with respect to Temperature and Humidity Test is to verify the fuel cell power plant's capability of operating in a residential setting, under conditions of high/low humidity, and high/low temperatures over a 24-hr period. The fuel cell power plant being evaluated shall be placed in the temperature and humidity chamber for testing. The test table lists the temperature and humidity settings for each test. When the temperature and humidity are stable, 24 hrs of the Residential Profile Test shall be performed. Appendix $\mathrm{O}$ gives further details. 


\section{Combined Heat and Power Test}

The purpose of the Combined Heat and Power Test is to measure and map the thermal output of a given Fuel Cell Power Plant under various load conditions. A Thermal Load Bank with all of the appropriate measurement and control devices will be used as the testing device. A Computerized Data Acquisition system will be used to capture and store collected data. Appendix P gives further details.

\section{Amp Circuit Breaker Overload Test}

The objective of the $15 \mathrm{Amp}$ Breaker Overload Test is to determine the fuel cell power plants capability to successfully open a 15-amp breaker under an overload condition, while maintaining power to circuits that are not overloaded. Appendix $\mathrm{Q}$ gives further details.

\section{Amp Breaker Short Circuit Test}

The objective of the 15 Amp Breaker-Short Circuit Test is to determine the fuel cell power plant's capability to successfully open a 15-amp breaker when subjected to a short circuit, while maintaining power to other circuits. Appendix $R$ gives further details.

\section{Power Grid Simulator Test}

The objective of Grid Simulation is to develop a characteristic profile for a given residential scale fuel cell power plant with respect to grid variations (transients, voltage surges/sags, frequency deviations, voltage phase differentiations, and waveform distortions). Overall performance of the residential scale fuel cell power plant will be determined for each variation. Appendix S gives further details.

NDCEE validated the Fuel Cell Evaluation Test Protocol by testing the residential scale Plug Power fuel cell system. The validation testing took place within the DOD FCTec. The Plug Power fuel cell system was operated on natural gas fuel supply during the anticipated validation phase. Validation of the test protocol was limited to using the existing equipment within the FCTec and the existing capabilities of the fuel cell system. 


\section{Conclusion}

Ten preliminary test protocols developed by NDCEE in support of testing and validating the performance and reliability of residential sized fuel cell systems were completed. These test protocols are viewed as living documents in that the existing protocols may be revised, or additional protocols created, to incorporate additional testing procedures as the fuel cell system needs evolve.

Two test protocols were validated due to the limited capabilities of the Plug Power Grid Connected system. The available Plug Power system only allowed the validation of the Combined Heat and Power Test, and the Grid Simulation Test. 


\section{Summary}

This work established test protocols, tested, and evaluated a UTC Fuel Cells 200 kilowatt (kW) PC25C Phosphoric Acid Fuel Cell Power Plant (PAFC) to achieve life-cycle-cost reduction and performance improvements. CERL and CTC also established a National Resource that can provide independent, unbiased testing and validation of fuel cell power plants for military and commercial applications. This test center (FCTec) provides the capability to significantly support the development and commercialization of fuel cell power plants.

The installation of a PC25C within $C T C^{\circ}$ s ETF was documented to develop a history of segmented costs for fuel cell installations of similar nature. CTC demonstrated that sub-contractors with little or no prior "fuel cell" experience could perform fuel cell installations economically. With the proper training and management, local contractors can successfully install large fuel cell power plants.

A temperature/humidity controlled environmental system and a shock/vibration system to support small, low power fuel cell testing was acquired and installed. These devices have been sized to accept fuel cell systems under $10 \mathrm{~kW}$ capacity, and will be applicable to both stationary and transportation fuel cells.

Testing was provided to validate baseline and performance enhancements of the PC25C. The tests were designed to provide UTC Fuel Cells and ERDC/CERL with data necessary for the evaluation of the PC25C performance. The testing did support the validation of the fuel cell operating capabilities, operational characteristics, and system responses.

Overall, the results of the testing performed by CTC at FCTec provided the basis for ongoing product development to obtain reliability and life cycle cost objectives and to expand applications for the PC25C. Because of the success of the FCTec testing, additional modifications to Task 211 were added to continue testing on the UTC Fuel Cells PC25 as well as to develop a residential sized standardized test protocol in coordination with the National Rural Electric Cooperative (NRECA). 


\section{Acronyms and Abbreviations}

\begin{tabular}{|c|c|}
\hline Term & Spellout \\
\hline ASTM & $\begin{array}{l}\text { American Society for Testing and } \\
\text { Materials }\end{array}$ \\
\hline CTC & Concurrent Technologies Corporation \\
\hline CAM & Contract Agreement Memorandum \\
\hline CDAQ & Control and Data Acquisition \\
\hline CERL & $\begin{array}{l}\text { Construction Engineering Research } \\
\text { Laboratories }\end{array}$ \\
\hline $\mathrm{CH}_{4}$ & Methane \\
\hline $\mathrm{CO}$ & Carbon Monoxide \\
\hline $\mathrm{CO}_{2}$ & Carbon Dioxide \\
\hline CSA & Cell Stack Assembly \\
\hline DOD & Department of Defense \\
\hline ECS & Electronic Control System \\
\hline ERDC & $\begin{array}{l}\text { Engineering Research and } \\
\text { Development Center }\end{array}$ \\
\hline ETF & Environmental Technology Facility \\
\hline EPA & Environmental Protection Agency \\
\hline FCTec & Fuel Cell Test and Evaluation Center \\
\hline FRP & Fiberglass Reinforced Plastic \\
\hline gpm & Gallons Per Minute \\
\hline FTP & File Transfer Protocol \\
\hline $\mathrm{H}_{2}$ & Hydrogen \\
\hline HVAC & $\begin{array}{l}\text { Heating, Ventilation and Air } \\
\text { Conditioning }\end{array}$ \\
\hline ISTA & $\begin{array}{l}\text { Information, Science, and Technology } \\
\text { Agency }\end{array}$ \\
\hline kW & Kilowatts \\
\hline LP & Liquid Propane \\
\hline
\end{tabular}

\begin{tabular}{|c|c|}
\hline Term & Spellout \\
\hline $\mathrm{N}_{2}$ & Nitrogen \\
\hline NDCEE & $\begin{array}{l}\text { National Defense Center for } \\
\text { Environmental Excellence }\end{array}$ \\
\hline $\mathrm{NH}_{3}$ & Ammonia \\
\hline $\mathrm{NO}_{2}$ & Nitrogen Dioxide \\
\hline $\mathrm{NO}_{\mathrm{x}}$ & Nitrogen Oxides \\
\hline NRECA & $\begin{array}{l}\text { National Rural Electric Cooperative } \\
\text { Association }\end{array}$ \\
\hline O\&M & Operation and Maintenance \\
\hline P\&ID & Process \& Instrumentation Diagram \\
\hline PAFC & Phosphoric Acid Fuel Cell \\
\hline PC25C & $\begin{array}{l}\text { UTC Fuel Cells } 200 \text { kW Phosphoric } \\
\text { Acid Fuel Cell Power Plant }\end{array}$ \\
\hline PCS & Power Conditioning System \\
\hline PEMFC & $\begin{array}{l}\text { Proton Exchange Membrane Fuel } \\
\text { Cell }\end{array}$ \\
\hline PMP & Program Management Plan \\
\hline PTP & Program Test Plan \\
\hline RFQ & Request for Quotation \\
\hline RNG & Reference Natural Gas \\
\hline sow & Statement of Work \\
\hline $\mathrm{SO}_{\mathrm{x}}$ & Sulfur Oxides \\
\hline THC & Total Hydrocarbons \\
\hline TLB & Thermal Load Bank \\
\hline VOC & Volatile Organic Compound \\
\hline
\end{tabular}




\section{Appendix A: Initial Report Task 211 (28 December 2000)}

\subsection{Introduction}

This report documents the activities performed by CTC for the first 2 years of Task N.211, U.S. Army ERDC/CERL. This report fulfills the requirement of Statement of Work (SOW) paragraphs 2.9.1 and 2.9.2 FY98 and FY99 Final Report. Provided is a brief summary of the initiation of this program, the fuel cell operating characteristics (baseline and extended tests), equipment procured, and lessons learned.

It is the objective of this U.S. Army ERDC/CERL funded program to provide testing and evaluations, in cooperation with UTC Fuel Cells of a PC25C. The focus of this test and evaluation effort is in support of life-cycle-cost reduction and performance improvement goals. It is also an objective of this program to provide the capability for independent design assessments of alternative technology fuel cell system configurations and components for achieving lower life cycle cost either through reduced capital cost, reduced operation and maintenance (O\&M) costs, or increased performance and reliability.

\subsection{FCTeC}

The DOD FCTec was designed for simple operation and maximum flexibility. It has been designed to allow future expansion in terms of additional fuel cells, as well as to accommodate future testing requirements. Much of the test equipment within the FCTec including electrical and thermal load banks has been assembled on portable skids for optimum space flexibility. The Control and Data Acquisition (CDAQ) system is located in the proximity of the fuel cell, allowing optimum efficiency in setting up and executing tests. All utilities are available nearby for economical connection. A propane gas fuel feed can be supplied through the use of a temporary outdoor tank system immediately outside the

FCTec area. Power plant exhaust is drawn through a hood and ductwork by a 
roof-mounted fan that exhausts the flow outside the building. The FCTec occupies space within CTC's existing ETF high bay area, as shown in Figure A1.

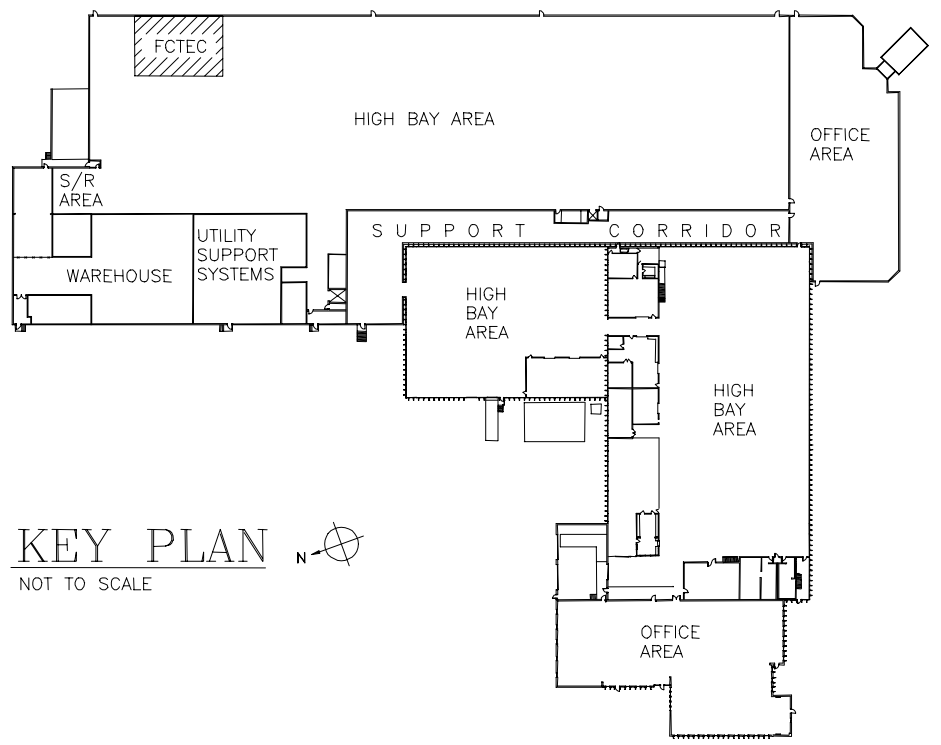

Figure A1. Key plan.

The testing and evaluation requirements identified by UTC Fuel Cells and ERDC/CERL for the PC25C were the basis of the design, testing capabilities and layout of FCTec. Modifications to FCTec and the enhancement of additional testing equipment were also required to accommodate the test and evaluation requirements for the Avista PEMFC power plant. These two test and evaluation programs have defined the initial design and testing capabilities of FCTec.

\subsection{Background}

ERDC/CERL, CTC, and UTC Fuel Cells, through meetings and reviews have collaborated to establish the PC25C Program Test Plan (PTP) document. The content of the document was established as a consensus plan to successfully achieve the goals of the overall program for the test and evaluation of the PC25C. The PTP defines the guidelines, strategies, specifications, and concepts to ensure a complete and consistent testing plan with the necessary engineering requirements for a successful program.

The PTP document provided the overall requirements and technical plan for CTC to implement the testing program for the PC25C. The PTP describes the general requirements for baseline power plant evaluation, as well as, improved power plant evaluations. In addition, this plan documented the control and data acquisition strategies, operations, data formatting reporting strategies, and the 
configuration management plans for the physical plant, operation, maintenance, and testing of the PC25C.

The first draft of this document was created and distributed as a shared project deliverable document to ERDC/CERL and UTC Fuel Cells on 17 December 1998. On 29 February 2000 a revision was completed on this document and submitted again as a shared project deliverable. The revision incorporated the test and evaluation requirements of the $\mathrm{PC} 25 \mathrm{C}$ that would be covered under the year two U.S. Army ERDC/CERL funding.

Also, under the year two U.S. Army ERDC/CERL funding, CTC, Avista, and ERDC/CERL collaborated to establish the SOW document that identified a consensus plan to successfully achieve the goals of the overall program for the test and evaluation of an Avista 720W PEMFC. The SOW defined the specifications and test concepts for a successful accomplishment of this program's goals.

Figure A2 provides a simplified schematic representation of the major FCTec facility capabilities currently used to support the test and evaluation of the PC25C. Details of the specific aspects of FCTec testing capabilities developed from the PTP and Avista's SOW documents are provided in the following sections.

\subsection{Thermal Load Bank}

A single thermal load bank system was designed and procured by CTC to support the test and validation of the high-grade and low-grade heat recovery of the PC25C. This system can interface with as many as two fuel cell heat exchangers simultaneously. It is equipped with flow, temperature and pressure sensors and can handle flow rates up to $100 \mathrm{gpm}$ and fluid temperatures up to $300^{\circ} \mathrm{F}$. The system is constructed out of stainless steel and may be directly integrated to fuel cell stacks. A process diagram of the thermal load bank is shown in Figure A3.

\subsection{Electrical Load Banks}

The electrical load banks may be used for both short and long-term electrical load testing in grid-independent mode of operation. The load banks designed and procured by CTC provide power plant loads that can be freely applied and removed without concern for affects on other surrounding equipment or systems. This equipment, as shown schematically in Figure A4, allows total control of power plant loading from 0 percent through overload, and with various combinations of resistive and inductive (i.e., motor) loads. 


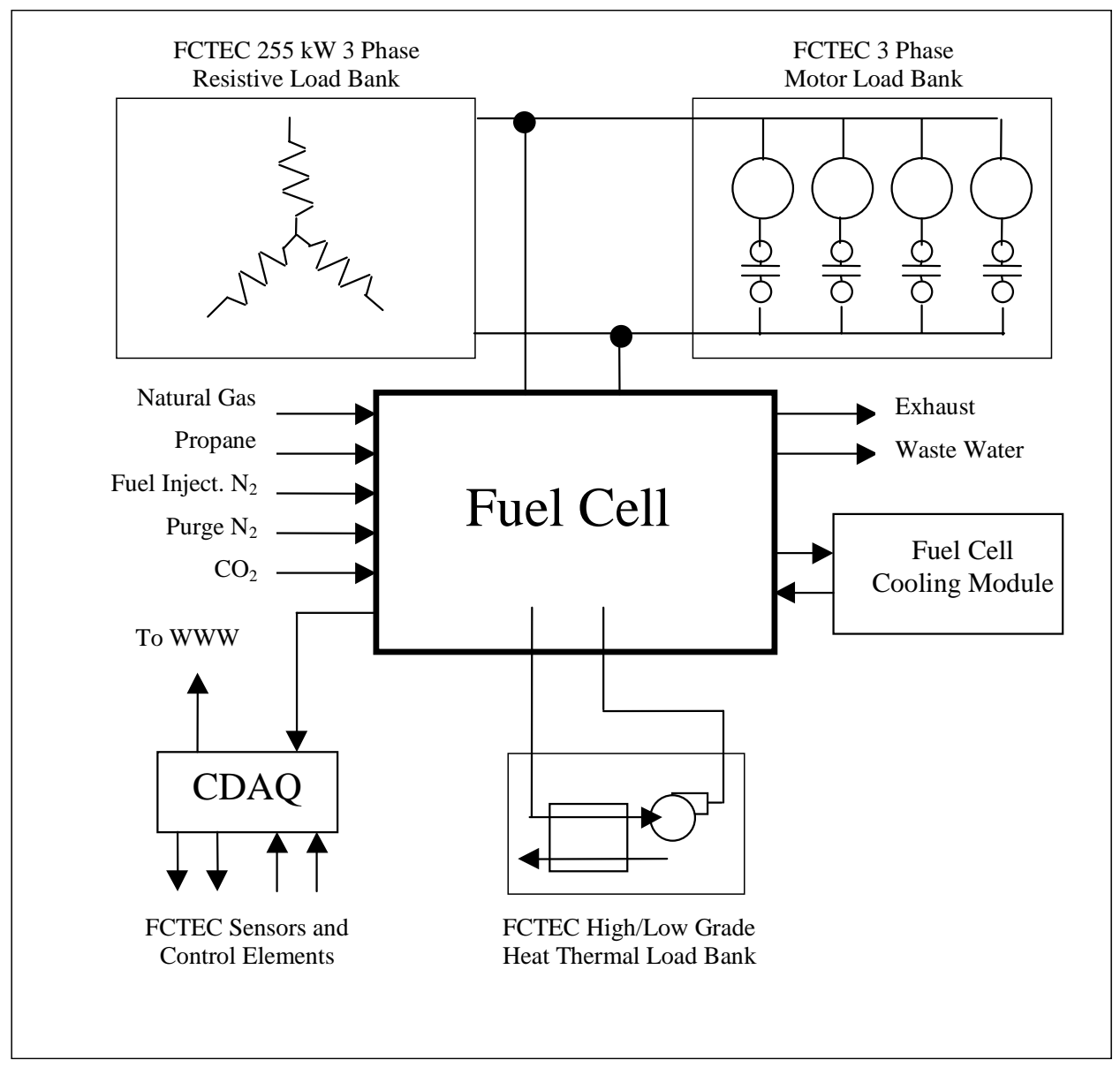

Figure A2. Overall process schematic.

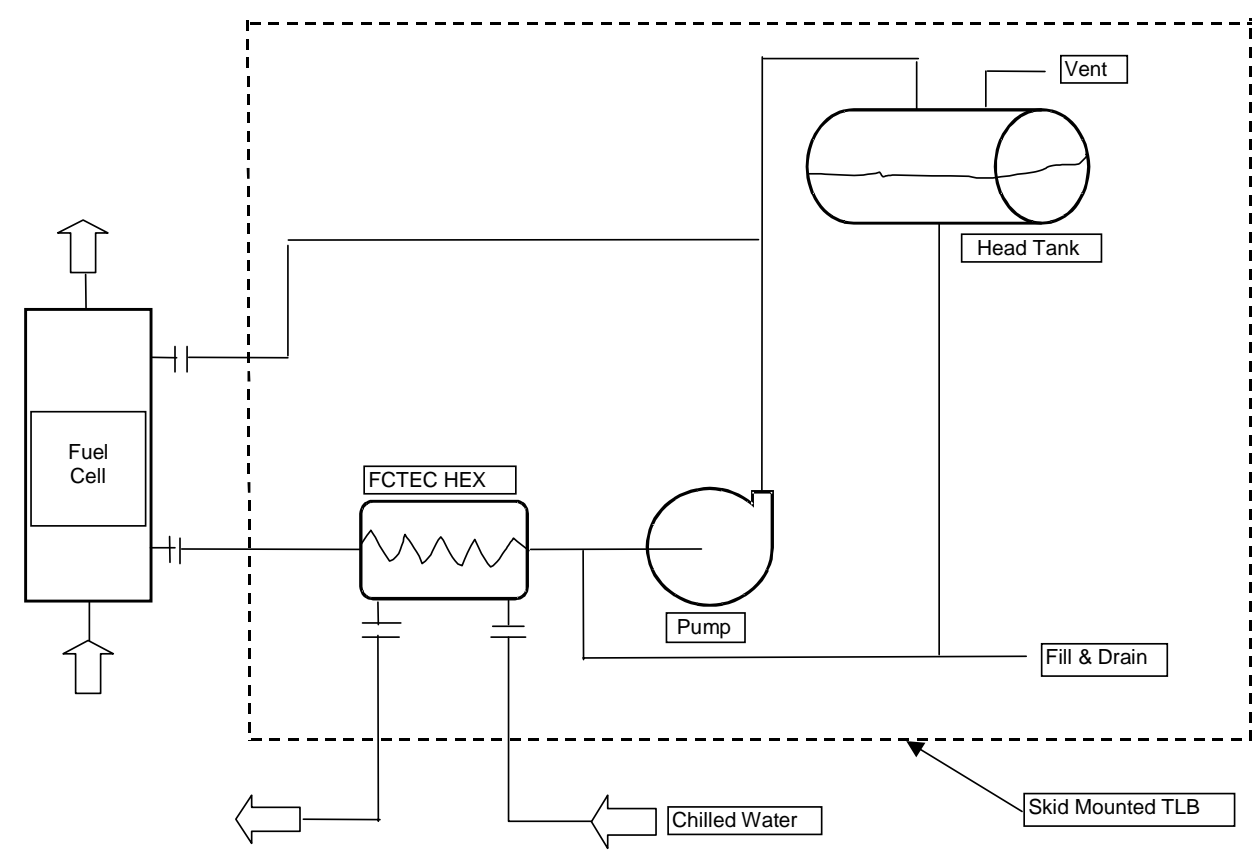

Figure A3. Thermal load bank diagram. 


\subsubsection{Resistive Load Bank}

The resistive load bank was designed and procured that can provide loads up to $255 \mathrm{~kW}$ with load changes as small as $5 \mathrm{~kW}$. The system is equipped with multiple contractors that enable loading changes to be made automatically during test execution. In-line voltage and current sensors are provided to acquire PC25C response characteristics.

\subsubsection{Motor Load Bank}

The motor load bank consists of fan, pump and dynamometer motor skids. In conjunction with the resistive load bank, these systems can simulate a wide range of practical electrical loads. The motor load bank test range is from 5 to $85 \mathrm{hp}$ in various configurations, including soft start and variable speed capabilities. Each system is equipped with voltage, current and kilowatt sensors.

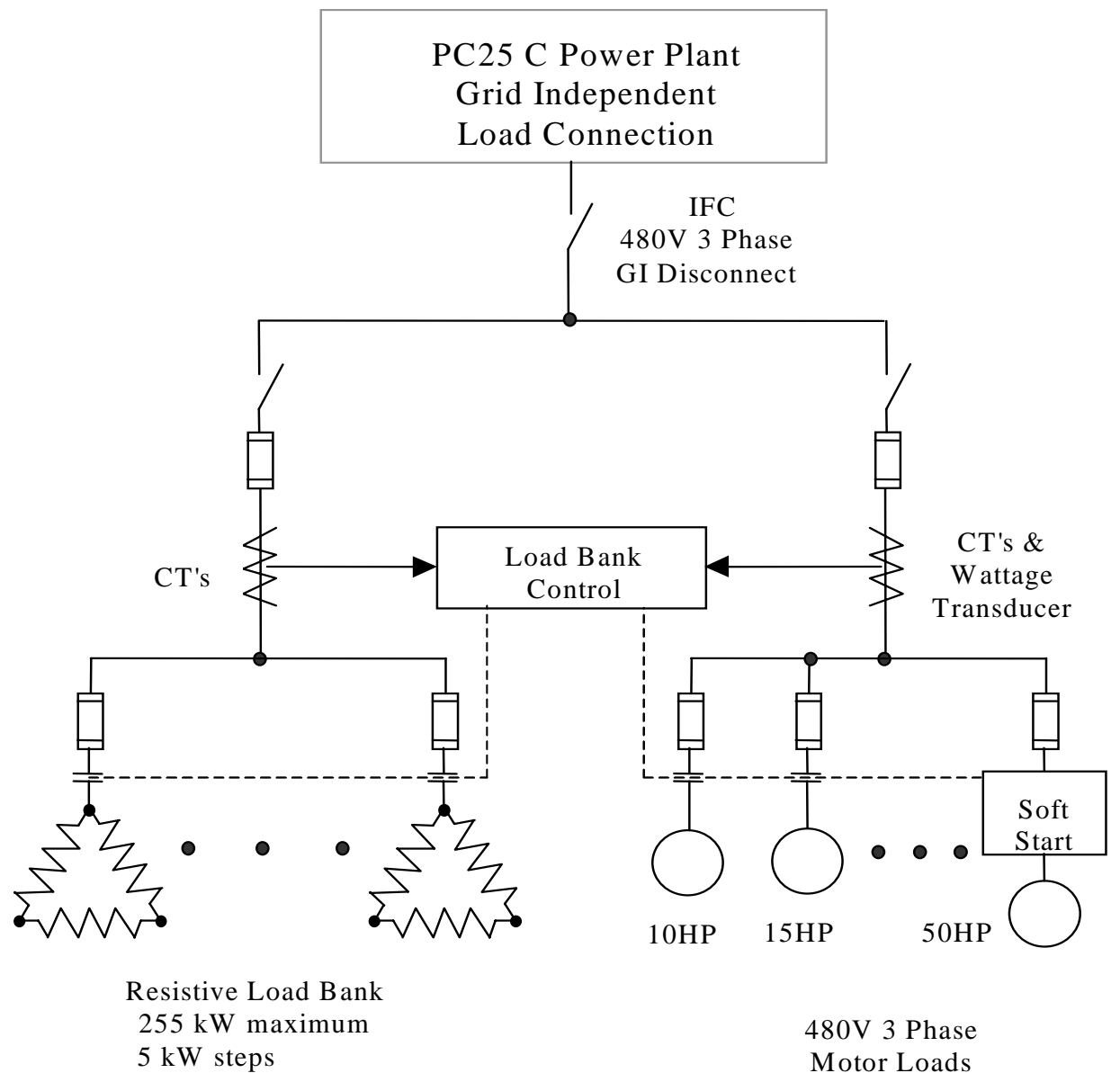

Figure A4. Electrical load bank block diagram. 


\subsection{Control and Data Acquisition System (CDAQ)}

The CDAQ is a PC-based system that was designed, constructed and executed by $C T C$ engineers. This system consists of two Pentium II based personal computers, various sensors and interconnecting hardware. The purpose of the CDAQ is fourfold:

6. Provide an automated means for collecting critical process and operating parameters which will be required to assess the results of the tests performed on the fuel cell

7. Provide long term storage for both the data acquired in item 1 and for data acquired as a result of other, manually collected, measurements including the gas analysis tests.

8. Provide a means for electronically disseminating the data to $C T C$, UTC Fuel Cells, Avista, and ERDC/CERL personnel for analysis and publication.

9. Control of test center elements to provide automated test execution where possible. This will expand the number of hours available for performing fuel cell tests.

The CDAQ consist of four integrated subsystems. These include the existing data acquisition capabilities built into the PC25C by UTC Fuel Cells, additional data acquisition capabilities provided by FCTec, a database repository for archiving collected data, and a web based operator interface, which allows the archived data to be viewed and/or uploaded for analysis. Figure A5 shows the complete CDAQ system. Each of the subsystems comprising the CDAQ system is described below.

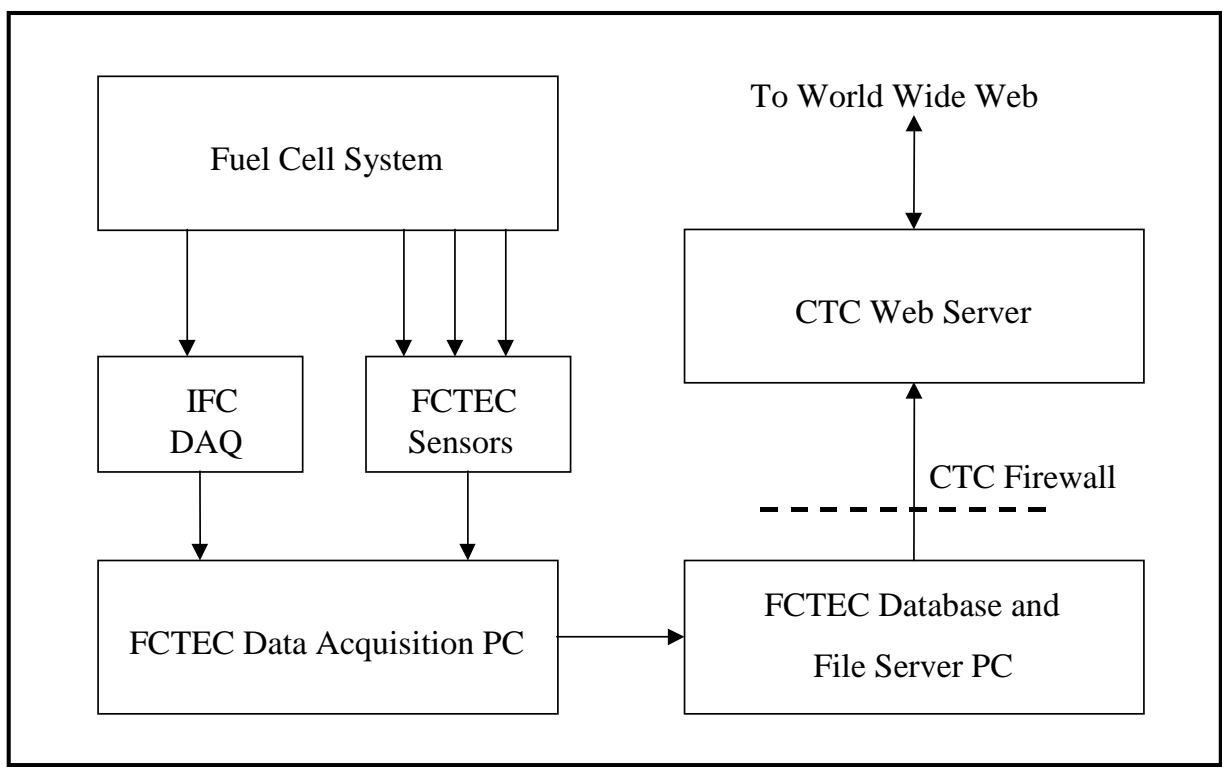

Figure A5. Control and data acquisition block diagram. 


\subsubsection{UTC fuel cells data acquisition system}

The fuel cell as delivered by UTC Fuel Cells, already incorporated a substantial data acquisition capability. UTC Fuel Cells has identified approximately 300 operating parameters, which are electronically accessible from their control system. These include such items as kilowatts of power generated, currents, voltages, power factors, and other critical operating parameters. UTC Fuel Cells provided $C T C$ with the communication protocol required to access these parameters via a spare serial port on the fuel cell controller. CTC used the protocol to develop a software application that acquired the data from the UTC Fuel Cells controller and archived it in the CDAQ Database.

\subsubsection{FCTec data acquisition system}

Several critical parameters required for the baseline testing are not available from the UTC Fuel Cells Data Acquisition System. These include various flow rates, system pressures, temperatures, currents, and other parameters identified throughout this document. CTC selected and installed these additional sensors into the FCTec. Data is automatically acquired from these sensors and stored in the CDAQ Database.

\subsubsection{CDAQ database}

Data acquired from both the UTC Fuel Cells Data Acquisition System and the FCTec Data Acquisition System is stored in a relational database. CTC developed the necessary data tables for test result storage, the necessary interfaces to communicate and accept data from the UTC Fuel Cells and FCTec Data Acquisition Systems and the necessary interfaces to the World Wide Web for accessing the data from the tables. In addition to the raw data storage, other information pertinent to the tests was also stored. These data include the test name, time and date when the test was performed, initial setup up conditions for the fuel cell, and other information of interest to the test evaluators.

\subsubsection{Internet Access to CDAQ Data}

The data collected and stored in the CDAQ Database is also available for viewing and/or downloading via a File Transfer Protocol (FTP). CTC developed the necessary modules that allow the test data to be viewed and downloaded via the FTP site. Access to this site and the test data are password protected. 


\subsection{Emissions Monitoring}

CTC procured laboratory instrumentation and a Continuous EmissionMonitoring (CEM) trailer in support of satisfying the testing requirements outlined within several baseline tests within the PTP. The laboratory instrumentation allowed direct reading, portable, air-monitoring capabilities for recording Hydrogen, Carbon Dioxide, Oxygen, Nitrogen, Methane, and Carbon monoxide. This equipment consisted of:

- Myron L - portable meter for measuring water conductivity

- Gelman - filter unit for turbidity testing

- CHEMet - kits for Dissolved Oxygen measurement

- Perkin-Elmer Gas Chromatograph - used to measure selected gases

- Gas sampling valve, columns and detector to allow for the analysis of light gases

- Testo Model 300XL - was used to measure oxygen, carbon dioxide, carbon monoxide and oxides of nitrogen

- Methane sensor - detecting methane at two alarm ranges.

The CEM trailer is a fully integrated system that is used to monitor fuel cell system stack emissions. The mobile system is equipped with instrumentation used to monitor and record $\mathrm{CO}, \mathrm{O}_{2}, \mathrm{CO}_{2}, \mathrm{NO}_{2}$, THC, and $\mathrm{SOx}$. Additional equipment procured to the CEM trailer equipment included:

- Analytical column, gas syringes, and gas standards - used with gas chromatograph to allow for the analysis of hydrocarbons in stack gases

- Velocity probes and sampling equipment - used to compliment existing stack sampling equipment for determining stack velocities

- Dry gas meter and a calibrated flow meter - used to assist in preparing calibration standards and measure gas volumes and flows.

\subsubsection{Water Quality Analysis}

CTC procured hand-held and laboratory instrumentation to support the water

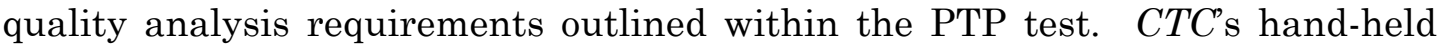
instrumentation provides the capabilities to capture and record conductivity, turbidity, dissolved oxygen and $\mathrm{pH}$. CTC's laboratory instrumentation provides the capability to conduct EPA approved laboratory procedures/tests to capture and record conductivity, turbidity, dissolved oxygen, $\mathrm{pH}$, metals, ions, silica, bacteria, total dissolved and suspended solids, and total organic carbon. 


\subsection{Fuel Supply}

For normal operation, FCTec can provide natural gas fuel through the existing ETF natural gas pipeline. FCTec is currently capable of supporting dual fuel testing. Facility modifications have been completed that will also allow a propane fuel supply system to be installed. The current arrangement will allow a propane system consisting of one 1,000 gallon tank to be position just outside of FCTec and connected directly to the fuel supply line of the PC25C. The Natural gas and propane feed lines are both equipped with instrumentation for the capture and recording of flow rates, fuel line supply pressures and incoming gas temperatures

\subsubsection{Fuel Blending System}

FCTec is also equipped with the instrumentation and hardware to allow other gases to be injected directly into the fuel supply line. A manifold system was designed and assembled by $C T C$ that provides the capability to control the injection of gases directly into the fuel supply line. The system is currently configured to support Nitrogen gas injection.

\subsection{Temperature/Humidity Environmental System}

In support of the Avista PEMFC test and evaluation program, CTC procured a Temperature/Humidity Environmental System. This system is capable of conducting environmental testing of low-power fuel cell systems and can achieve temperature ranges of -10 to $+140^{\circ} \mathrm{F}$ and humidity ranges of 35 to 95 percent on rated loads.

\subsection{Vibration Test System}

CTC also procured a Vibration System in support of the Avista PEMFC test and evaluation program. This system meets the requirements of ASTM, the Information, Science, and Technology Agency (ISTA), and other industry-standards product test specifications. The vibration system is used to simulate shock and vibration effects on low-power fuel cell systems. The capabilities on rated loads of the system are:

- 13,000 lb. Force

- $70 \mathrm{in} /$ second velocity

- $5 \mathrm{~Hz}$ to $2000 \mathrm{~Hz}$ frequency

- sine, random, and shock profiles. 


\subsection{FCTec Promotional Activities}

To assist with the promotion of the DOD FCTec, CTC and ERDC/CERL collaborated to create a program Fact Sheet and Website. These activities were completed to provide information about the test center to fuel cell manufacturers.

\subsubsection{FCTec Fact Sheet}

The FCTec Fact Sheet outlines the background, objectives, capabilities and systems of FCTec. This fact sheet provides photographs of the test systems currently installed within the FCTec. The fact sheet has been distributed to all FCTec visitors and at fuel cell technology seminars and conferences that CTC staff attend.

\subsubsection{FCTec Web Site}

The FCTec Website can be accessed at http://www.fctec.com. This site also outlines the background, objectives, capabilities and systems of FCTec along with the current clients and the objective of each test and validation program. This site provides photographs of the test systems currently installed within the FCTec.

\subsection{Installation}

At the request of ERDC/CERL, the procedures and costs associated with the FCTec PC25C installation and start-up were documented by CTC. This information is provided within this Final Report. The following sections summarize the background, the PC25C installation within FCTec, DOD PC25C installation comparisons and $C T C^{\prime} s$ installation recommendations resulting from our experience.

\subsection{Background}

$C T C$ was tasked with determining an optimum site within available $C T C$ facilities for the location of the FCTec. CTC prepared a suitable site for the execution of the test program and acquired the necessary equipment and instrumentation to satisfy the test program requirements. CTC designed, built and installed facility modifications necessary to accommodate the fuel cell installation consistent with the requirements in the Program Management Plan, including surrogate systems to supply the necessary capabilities for the electrical and thermal outputs of the fuel cell. 
The design takes into account provisions for future expansion of the FCTec to accommodate additional fuel cells and/or different fuel cell technologies. CTC designed and installed a central computer system in close proximity to the fuel cell for data acquisition and operation control.

CTC received a government supplied PC25C manufactured and delivered by UTC Fuel Cells. ERDC/CERL funded the fuel cell acquisition and installation through the start-up and acceptance test phase of the contract. UTC Fuel Cells was responsible for the power plant installation, including start-up and acceptance testing, at the CTC prepared site. CTC actively participated in the installation, initial start-up, and acceptance test as support to UTC Fuel Cells. CTC and UTC Fuel Cells worked together to install the hardware connections that physically integrate the power plant with the FCTec equipment.

\subsection{FCTec PC25C Installation}

The FCTec was developed within CTC's ETF. The PC25C manufactured by UTC Fuel Cells was installed within this area. The primary installation contractor was GBC Electrical Services, which used local subcontractor support to accomplish the installation requirements. The major subcontracts required to support the installation were: Electrical, Mechanical, Rigging Services, and HVAC/ Ventilation.

The indoor application of the $\mathrm{PC} 25 \mathrm{C}$ at the FCTec site required a ventilation system to extract the power plant exhaust. CTC was responsible for the procurement and installation of the ventilation system with UTC Fuel Cells providing the engineering, equipment specification, and design drawings. The cost of the ventilation system was not included in the base installation contract with GBC Electrical Services but is reflected in the cost information.

GBC Electrical Services' contract with UTC Fuel Cells for the CTC FCTec fuel cell installation was $\$ 67,989$ dollars. That cost is segmented into materials, $(\$ 36,924)$, labor, $(\$ 27,600)$, and overhead and profit, $(\$ 3,465)$. Nontypical items associated with this installation were the indoor exhaust ventilation system and the fiberglass reinforced plastic (FRP) elevated grating used to cover the heat recovery piping exiting the power plant. The FRP grating was used to facilitate easy and unobstructed walking access near the high traffic area around the PC25C. The cost for this grating was $\$ 3,865$ and was included in the UTC Fuel Cells contract.

$C T C$ was responsible for the installation of the exhaust ventilation system. The cost of the complete ventilation system installation was $\$ 10,500$. CTC subcon- 
tracted this work to a local Heating Ventilation and Air Conditioning (HVAC) contractor through a competitive bid process.

Table A1 lists actual installation cost breakdown by discipline and the corresponding percentages as compared to the total.

Table A1. Task 211, installation costs by discipline.

\begin{tabular}{|c|c|c|c|c|c|c|}
\hline \multicolumn{7}{|c|}{ Actual Installation Costs } \\
\hline Electrical & Mechanical & Rigging & FRP Grate & Resin/Glycol & Overhead & Total \\
\hline$\$ 19,954$ & $\$ 27,763$ & $\$ 9,600$ & $\$ 3,865$ & $\$ 3,342$ & $\$ 3,465$ & $\$ 67,989$ \\
\hline $29 \%$ & $41 \%$ & $14 \%$ & $6 \%$ & $5 \%$ & $5 \%$ & $100 \%$ \\
\hline
\end{tabular}

Note that approximately $\$ 6,000$ in UTC Fuel Cells administrative costs is not included in the total installation cost of $\$ 67,989$ reported by GBC Electrical. The UTC Fuel Cells reported cost was $\$ 73,899$.

The electrical and mechanical work represented 70 percent of the total project cost with mechanical being the largest cost at 41 percent. This is consistent with the high quantity of piping, used to supply the power plants needs as well as the users heat recovery needs. Rigging and final placement of the power plant accounted for approximately 15 percent of the total. Startup materials and overhead requirements were 10 percent of the project cost.

A log of work hours by subcontract discipline was maintained during the fuel cell installation to identify labor requirements between the designated trades. Table A2 illustrates the total hours that were required for each discipline to complete the installation.

Table A2. Task 211, installation labor by discipline,

\begin{tabular}{|c|c|c|c|c|}
\hline \multicolumn{5}{|c|}{ Labor Hours by Discipline } \\
\hline Rigging/Crane & Mechanical & Electrical & Supervision & Ventilation * \\
\hline $64 \mathrm{hrs}$ & $232 \mathrm{hrs}$ & $80 \mathrm{hrs}$ & $176 \mathrm{hrs}$ & $206 \mathrm{hrs}$ \\
\hline Total = 758 labor hours & \multicolumn{4}{l}{} \\
\hline * Ventilation system by CTC - included in the total work hour requirement. \\
\hline
\end{tabular}

The FCTec installation was straightforward and required only short utility runs coupled with ideal working conditions. This is reflected in the lean work-hour total that was required to complete the job. The FCTec installation spanned a 6 week period with the bulk of the work being completed in 4 weeks. 


\subsection{FCTec PC25C Installation Comparison with other DOD units}

The simplification and standardization of typical practices for the installation of the PC25C is imperative to reduce the cost of fuel cell systems. Many engineers and contractors are not familiar with fuel cell designs and are hesitant to consider them as typical distributed generation installations. Diesel generators have been in the engineering and construction arena for many years and everyone involved is very comfortable with their procurement and installation. This familiarity leads to lower costs for their integration into the electrical and mechanical systems. As fuel cell power plants become more common, they too will become second nature to the contract industry.

The development of a site installation evaluation document to simplify and standardize the estimating process for all PC25C locations will assist this transition. The information systematically estimates basic power plant installation requirements and any options that are desired. The spreadsheet accounts for geographic cost indexes for different labor and material rates across the United States and Canada to apply a rating cost factor after the estimate is developed. In addition, indirect costs are accounted for in developing the total cost estimate.

A typical PC25C installation (outside installation using the standard heat recovery capability) will include the following basic components:

- concrete pad for the Fuel Cell, designed for the structural weight of the system and site geological requirements

- concrete pad for the air cooling module if located separately from the fuel cell

- 6 -ft high chain link security fence surrounding the fuel cell and cooling module

- $\quad$ system water piping connections, supply and drain

- nitrogen gas system for purge requirements

- one data line and one voice telephone line

- electrical interconnection to grid

- heat recovery thermal interface

- standard instrumentation.

Non-typical items associated with PC25C installations (which are site specific and will require input from engineering and operation personnel at the specific site) may be as follows:

- thermal storage equipment, for the possibility of increased use of the available thermal output

- high voltage requirements, if the fuel cell system is to be connected directly to a high voltage electrical system electrical interconnection to the grid independent electrical loads 
- electrical interconnection to the grid independent electrical loads

- extended or lengthy electrical and thermal connection interfaces (long interfaces increase installation costs)

- special piping material needs, site specific requirements

- special thermal equipment (absorption chilling equipment to supplement a continuous cooling need)

- dual fuel input capabilities

- complex site conditions and utilities interference

- indoor installations, a ventilation system is a requirement for indoor installations.

A typical fuel cell installation would involve a flat site with minimal site preparation required. An existing concrete pad in close proximity to the electrical and thermal source would create an ideal site for the equipment placement. The typical items listed above are necessary for a PC25C installation.

For a typical PC25C installation, the required length to reach an appropriate electrical interconnection and the thermal interface should be $100 \mathrm{ft}$ or less. The average cost for a typical installation excluding any geographic cost index adjustments for labor should be in the $\$ 90,000$ to $\$ 100,000$ range. Any nontypical or auxiliary equipment will be in addition to the base installation cost.

The installation costs for some of the DOD fleet have been recorded and tabulated to allow review of installation options, interface requirements, and installation cost. These initial fuel cell systems cost an average of $\$ 110,109$ with a minimum cost of $\$ 83,729$ and a maximum cost of $\$ 199,388$.

\subsection{Installation Recommendations}

The FCTec was unique due to the indoor installation and close proximity to the electrical and thermal connections. The CTC PC25C installation cost of $\$ 67,989$ was significantly lower than standard typical costs because of excellent project management, close collaboration between the trades involved, and short utility service requirements.

There are many options available to minimize the cost of a fuel cell installation. The following are offered as cost saving guidelines to aid in the installation process:

- Use reliable experienced local contractors.

- Keep electrical and thermal utility interfaces to a minimum.

- Use optimum site location planning (locate to the most favorable site for the electrical and thermal needs within the facility). 
- Maintain a compressed installation schedule to complete all trades at the same time to avoid inefficient dead time and overlap.

- Contact an experienced local rigging company and conduct a site visit to properly plan the placement procedure.

- Use the recovered thermal heat on a continuous basis (the higher the thermal use, the better the economic payback of the system).

\subsection{Summary of Completed Tests}

Seven tests were performed by CTC on the PC25C. Several of the tests required re-evaluation and re-testing to assure proper results. Two of the originally scheduled tests were not performed because of changes in scope of UTC Fuel Cells and ERDC/CERL. The development of a web based FTP site allowed for the quick transfer of large test data files to appropriate customers. The test data has been transmitted to both UTC Fuel Cells and ERDC/CERL via the FCTec FTP site. Customer information and data will not be presented in this report to protect client confidentiality.

\subsection{Reference Natural Gas Testing}

The purpose of Reference Natural Gas testing was to establish a database of power plant parameters that represent operations in a standard configuration for use in comparison to subsequent testing using alternative fuels and/or enhanced configurations.

The power plant was operated on utility natural gas in the grid connect mode with no customer heat recovery, for all test runs. The tests were established and designated by net power output levels to include idle mode, $50 \mathrm{~kW}, 100 \mathrm{~kW}$, $125 \mathrm{~kW}, 150 \mathrm{~kW}, 175 \mathrm{~kW}$, and $200 \mathrm{~kW}$. The power plant systems were set up and configured for normal operation per UTC Fuel Cells PC25C operations manual.

CTC and UTC Fuel Cells reviewed all data captured for each power level following the completion of this test series. All pertinent measured, monitored, and computed parameters from the FCTec data acquisition system and the PC25C's existing data acquisition system were recorded and stored for each test run. Specific data samples captured for this test series included:

- Gas analysis $\left(\mathrm{CO}_{2}, \mathrm{CO}, \mathrm{CH}_{4}, \mathrm{~N}_{2}\right)$ of the reformer process exit

- Anode inlet and exit gas analysis $\left(\mathrm{CO}_{2}, \mathrm{CO}, \mathrm{CH}_{4}, \mathrm{~N}_{2}\right)$

- Burner exhaust oxygen concentration

- Cathode exit oxygen concentration 
- Cell stack assembly Cell Stack Assembly (CSA) cross pressure (anode inlet to cathode inlet)

- Glycol inlet and exit temperatures of cooling module

- Ambient temperature of cooling module area

- Exiting air temperature from cooling module fans

- Cooling module on/off status

- Feed water on/off status.

Using this data, UTC Fuel Cells was able to monitor the operational methods of the power plant. The 19 tube reformer, in this revised model, was the first to be tested in this fashion. The testing revealed some interesting parameters that required adjustments to the system. The reformer uses steam in its reaction of converting methane, $\mathrm{CH}_{4}$ into $\mathrm{H}_{2}$. This conversion requires a specific steam to carbon ratio to operate at peak efficiency. A test to authenticate the amount of steam converted was added to validate the ratio and to make adjustments as required. Steam ratio adjustments were made to improve the power plant performance.

\subsection{Special Fuels Testing}

The objective of this test was to evaluate fuel cell performance when natural gas fuels containing high levels of Nitrogen gas $\left(\mathrm{N}_{2}\right)$ contaminants are used. Nitrogen, contained in natural gas is converted into ammonia gas $\left(\mathrm{NH}_{3}\right)$, which is known to reduce fuel cell life and adversely affect fuel cell operating performance. The data collected under this test provided quantifiable information regarding the amount of ammonia formed and reacted as a result of various $\mathrm{N}_{2}$ gas quantities and cell stack load conditions.

The PC25C operated on utility natural gas in the grid connect mode with no customer heat recovery, for all test runs. During this test, $\mathrm{N}_{2}$ gas was injected directly into the natural gas supply downstream of the FCTec fuel flow meter. Tests were performed at $0,5,10$, and 15 percent $\mathrm{N}_{2}$ injection into the fuel for idle, $100 \mathrm{~kW}$, and $200 \mathrm{~kW}$ electrical loads. Data were collected at each $\mathrm{N}_{2} / \mathrm{kW}$ combination to assess the effects of both $\mathrm{N}_{2}$ concentration and electrical load on ammonia production and cell stack reaction. The power plant systems were set up and configured for normal operation per the PC25C's operations manual.

All pertinent measured, monitored, and computed parameters from the FCTec data acquisition system and the PC25C's existing data acquisition system were recorded and stored for each test run. The primary parameters, which are of interest during this test, include the following:

- percentage of $\mathrm{N}_{2}$ in the fuel supply 
- $\mathrm{N}_{2}$ flow rate

- $\mathrm{N}_{2}$ pressure

- electrical load

- $\mathrm{NH}_{3}$ concentration at cell stack inlet

- $\mathrm{NH}_{3}$ concentration at cell stack exit.

Initially the testing was performed using a test method that incorrectly removed any ammonia that may have been in the sample. This was verified after performing a second and third test whereby modifying the sample train to assure that any ammonia present is captured and evaluated.

All other data available via FCTec data acquisition system and through the existing PC25C data acquisition system, was also collected to ensure that a complete record of both the initial setup and actual operating conditions during the test are recorded.

\subsection{Heat Recovery Testing}

The purpose of heat recovery testing was to validate the useful heat recovery capability from the PC25C low-grade and high-grade heat exchangers (HEX-880 and HEX 490).

The power plant was operated on utility natural gas in the grid connect mode for all test runs. The test operation was established by maintaining a constant return temperature within the customer's coolant system, while varying the coolant flow rate. One hour was allotted to allow the system to become stable following an adjustment to either the temperature or flow rates of the coolant. Two hours were allotted to allow for power level adjustments. Three modes of testing were performed to validate various customers' usage of the heat recovery capability from the PC25C. Each mode was tested at $100 \mathrm{~kW}$ and $200 \mathrm{~kW}$ power levels.

\subsubsection{Mapping of High-Grade Heat Exchanger (HEX 490)}

Water was used as the coolant for both PC25C and customer side during this test. The customer return temperature was varied from $100^{\circ} \mathrm{F}$ to $250^{\circ} \mathrm{F}$ in increments of $50^{\circ} \mathrm{F}$. The coolant flow rates for each temperature were varied from $10 \mathrm{gpm}$ to $70 \mathrm{gpm}$ in increments of $20 \mathrm{gpm}$. 


\subsubsection{Mapping of Low-Grade Heat Exchanger (HEX 880) with Water/Glycol Coolant when High-Grade Heat Exchanger (HEX 490) is in use}

A water and glycol mixture was used as the plant side coolant in the low-grade system during this test. The high-grade heat recovery was operated at a fixed nominal capacity with water as the coolant medium. During this test, the customers low-grade return temperature was varied from $60^{\circ} \mathrm{F}$ to $160^{\circ} \mathrm{F}$ in increments of $20^{\circ} \mathrm{F}$. The coolant flow rates for each temperature was varied as specified in Table A3.

Table A3. Task 211, hex 880 test parameters, water/glycol - high grade in use.

\begin{tabular}{|c|c|c|c|c|c|}
\hline $\begin{array}{c}\text { Customer Side } \\
\text { Return Temp ( }{ }^{\circ} \text { F) }\end{array}$ & \multicolumn{6}{|c|}{ Customer Side Flow Rate (gpm) } \\
\hline 60 & 10 & 15 & & & \\
\hline 80 & 10 & 15 & & & \\
\hline 100 & 10 & 15 & 20 & 25 & \\
\hline 120 & 10 & 15 & 25 & 45 & 90 \\
\hline 140 & 10 & 15 & 25 & 45 & 90 \\
\hline 160 & 10 & 15 & 25 & 45 & 90 \\
\hline
\end{tabular}

\subsubsection{Mapping of Low-Grade Heat Exchanger (HEX 880) with Water/Glycol Coolant when High-Grade Heat Exchanger (HEX 490) Is Not in Use}

A water and glycol mixture was used as the plant side coolant in the low-grade system during this test. During this test, the customers low-grade return temperature was varied from 60 to $160^{\circ} \mathrm{F}$ in increments of $20^{\circ} \mathrm{F}$. The coolant flow rates for each temperature were varied as specified in Table A4.

Table A4. Task 211, hex 880 test parameters, water/glycol - high grade not in use.

\begin{tabular}{|c|c|c|c|c|}
\hline $\begin{array}{c}\text { Customer Side } \\
\text { Return Temp ( }\end{array}$ & \multicolumn{5}{|c|}{ F) } & \multicolumn{4}{|c|}{ Customer Side Flow Rate (gpm) } \\
\hline 60 & 10 & 15 & & \\
\hline 80 & 10 & 15 & & \\
\hline 100 & 15 & 25 & 45 & 90 \\
\hline 120 & 15 & 25 & 45 & 90 \\
\hline 140 & 15 & 25 & 45 & 90 \\
\hline 160 & 15 & 25 & 45 & 90 \\
\hline
\end{tabular}

\subsection{PCS and ECS Ventilation Testing}

The purpose of PCS (Power Conditioning System) and ECS (Electronic Control System) ventilation testing was to determine the temperature distribution within the ventilation compartment. Air-cooling within the PCS/ECS compart- 
ment was evaluated. The PC25C was operated on utility natural gas in grid connect mode. During this test, thermocouples were placed in the PCS/ECS compartment to acquire temperature data. The temperature data were captured and analyzed for test runs at idle and rated power level at 0.85 power factor.

In addition to the data collected from the thermocouples, all pertinent measured, monitored, and computed parameters from the FCTec data acquisition system and the PC25C data were recorded and stored for each test. No high temperature locations were identified that would require modifications to the compartment or alternate ventilation configurations.

\subsection{Grid Independent Testing}

\subsubsection{Transient Response}

The purpose of Grid Independent Testing was to gather data delineating PC25C capabilities and electrical output characteristics under changing electrical load conditions, primarily in a grid independent mode. For this test, the power plant fuel was natural gas and no heat recovery was used. Electrical loading was applied through a combination of resistive and motor loads. These electrical load banks were dedicated, isolated units that allowed for maximum flexibility of testing. Several sizes of electric motors between $5 \mathrm{hp}$ and $50 \mathrm{hp}$ supplied motor loading with both high-inertia and HVAC-type mechanical shaft loading including fan and pump loads. Several factors of power plant response were monitored. These included measures of voltage stability, power quality, and the capability of the plant to deliver the required power through transient load changes. Also, response to short circuit fault conditions and the ability to energize the load when transferring from grid connected to grid independent were tested. Grid Independent Testing was broken down into the following five test modes:

- overload test

- grid connect cycle to grid independent

- power quality

- short circuit.

The test modes along with the additional testing parameters completed under this scope are discussed below:

\subsubsection{Transient Response (Motor Starting Loads)}

This exercise tested the capability of the power plant to handle transient power demands created by induction motor startups. A typical PC25C installation in- 
cluded an electrical load consisting of a combination of resistive and inductive components. For this model, the inductive portion of the load consisted of highinertia/motor loads (dynamometer) and HVAC motor loads including fans and pumps. Starting motor loads can be a severe test of a power system with initial inrush currents sometimes exceeding 7 times normal motor full-load current ratings.

This test used combinations of both the resistive and motor load banks in a grid independent mode. The test was executed in multiple stages. In each trial, the power plant was subject to a nominal steady-state electrical load (combinations of resistive and inductive loads). Various motor loads ranging between $5 \mathrm{hp}$ and $50 \mathrm{hp}$ were added to the fuel cell power requirement, and the power plant response was monitored. The motors were connected to various systems including centrifugal fans and pumps. Execution of this test included use of both across the line and soft-start controllers. Before, during, and after each load addition test, system voltage, current, wattage, and power quality were recorded along with the nominal ratings of the loads.

Five transient tests were performed on the PC25C. The PC25C was operated in grid independent mode and configured with a base load for each test. Resistive and inductive loads were applied individually in steps to the base load. The duration of each load step was ten (10) seconds. The step load then was removed and the base load applied for another ten seconds prior to the next step load. Data were captured at high speed for a duration of twenty (20) seconds for each step load ( 5 seconds at base prior to load step +10 seconds of applied load +5 seconds after step removed). Several of the step loads caused an overload on the PC25C and subsequently forced either an idle state or a shutdown.

\subsubsection{Overload Test}

The PC25C's ability to handle overloads was tested during this exercise. Present published specifications on the power plant list its steady-state capacity at $200 \mathrm{~kW}$ with overload capabilities up to 5 seconds at $240 \mathrm{~kW}$. For this test, the PC25C was configured for grid independent operation with no heat recovery. A resistive load bank was used as the electrical loading device. Nominal loading levels and system response were recorded, along with specific output voltage, current, wattage, and transient voltage/current response, for each test.

Two overload test formats were performed on the PC25C. The first test format consisted of applying overload steps for 1-, 2-, 3-, 4-, and 5-second durations to a base load of $200 \mathrm{~kW}$. The cumulative resistive load steps were applied to the PC25C output until either an overload condition was reached (PC25C goes to idle 
or shutdown) or all steps were successful. Data were captured at high speed for each step load at selected test duration's.

The second test format consisted of starting with the highest power level from the previous overload test that was able to operate for a maximum 4 second duration. This overload condition was tested to verify that a steady state continuous power condition could be achieved for a 10-second duration. The overload amount was reduced by $5 \mathrm{~kW}$ steps as needed to obtain the overload steady state continuous operating condition of the PC25C.

\subsection{Dual Fuel Testing}

Dual fuel testing was to be performed on the PC25C to evaluate the adaptability of the power plant during conversion from one input fuel stream to another. This testing documented the applicability of PC25C in emergency power applications. This testing was also necessary to gain AGA certification for the PC25C while operating on liquid propane (LP) fuel.

This testing has been postponed by UTC Fuel Cells due to development of the new reformer catalysts. $C T C^{\prime}$ s activities in support of performing this test series were completed prior to receiving UTC Fuel Cells postponement of propane testing. A temporary propane system was installed and development of the test plan was completed. This test may be included in future testing of the PC25C. The availability of two input fuel streams, from separate sources, will allow PC25C to be designated as back-up emergency power providers. A dual fuel PC25C will provide increased system reliability.

\subsection{Water Recovery Testing - Air Cooling Module Performance}

This test has been discontinued in favor of performing extended baseline tests. The objective of Water Recovery Testing will be to characterize and validate the new high performance air cooling module and provide data to establish a set of limits within which the power plant can recover sufficient water required for operation. This test is anticipated to be completed during year three of this program. CTC and UTC Fuel Cells completed drafting of the preliminary test plans.

\subsection{Water Quality Testing}

The objective of water testing was to assess the water quality within the PC25C during operation. Fuel cell reliability and long term operation is often dependent on water quality. Previous fuel cell stack failures have been attributed to 
poor water quality causing deposit build-up at essential cooling locations throughout the fuel cell. Improvements in input water quality and on-board water conditioning systems will provide enhanced system reliability.

The water quality of the fuel cell feed water (HV453), the TMS Loop (HV431), the on-board water storage tank, and the make-up water were sampled at a minimum of 48-hr intervals during the operation of the PC25C. Water samples from these locations were taken from inspection ports integrated into the system. Make up water to the power plant was taken from the deionized water system supply at the FCTec.

Samples were analyzed to document $\mathrm{pH}$, conductivity, dissolved oxygen, and turbidity. Water temperature, power levels, and ambient air temperatures were measured and documented at the time of each sample event. Water quality test logs and charts were generated to trend each parameter.

Monthly, samples were collected and analyzed using laboratory equipment and the results compared to the analyses gathered at the power plant. This was done to assess the adequacy of the field methods for generating acceptable results. Laboratory analysis was also performed to collect information on Total Suspended Solids, Total Dissolved Solids, silica, Standard Plate Count, Total Organic Carbon, Metals (iron, copper, calcium, magnesium, and sodium) and ions (chloride, sulfate, nitrite, nitrate, and phosphate) during operation and over an extended period.

\subsection{Emissions Sampling}

Exhaust emission sampling was performed on the PC25C during the Baseline Power Plant Evaluation. This test was performed to verify emission levels of the PC25C operating on natural gas. The measured values allowed for comparison to historical $\mathrm{PC} 25 \mathrm{C}$ emission data.

The emission output from the power plant was monitored and tested during operation with 100 percent utility natural gas. The power plant was operated in the grid-connect mode with no customer heat recovery, at $100 \mathrm{~kW}$ and $200 \mathrm{~kW}$ power levels.

The test results were documented to allow for future comparison of fuel cell emissions. The test was performed using Continuous Emissions Monitoring (CEM) equipment to monitor carbon monoxide (CO), nitrogen oxides (NOx), volatile organic compounds (VOC), total hydrocarbons (THC), and sample temperatures. Excess oxygen $\left(\mathrm{O}_{2}\right)$ was also measured at the Power Plant exhaust during 
the emission tests. The emission tests compared the input, ambient air quality information with that measured from the fuel cell exhaust.

At least three 1-hr tests were performed at each power level. All equipment was calibrated using standard gases prior to each test. Software was used to capture data from each instrument during calibration and testing, and an average concentration was generated. All equipment was checked using standard gases after each 1-hr test to verify that the equipment operated correctly during testing. If any instrument showed drift during the data collection, the test was repeated.

\subsection{Lessons Learned}

Provided below are problems that were encountered during the first 2 years of this program that caused either modifications to the test schedule or contributed to unplanned costs. Where appropriate, lessons learned from these issues are presented.

\subsection{PC25C PAFC Power Plant Delivery}

The planned delivery date of the PC25C to FCTec was April 1, 1999. The power plant's actual delivery date to FCTec was 11 October 1999. Three (3) revised delivery dates were provided before the power plant actually arrived. A total of five project schedule modifications were required to address the delays of the delivery of the power plant. In addition, $C T C$ had to reduce staffing of the fuel cell team until the power plant was installed and testing was able to start. The delays in delivery of the power plant resulted from issues that arose during the fabrication and testing at the manufacturer's site of several of the power plant systems.

Resolution of the delivery issues was outside of CTC's control. CTC in cooperation with UTC Fuel Cells and ERDC/CERL did draft a project schedule, which anticipated the delivery date, installation completion date and the planned start date for testing. However, the manufacturing complexities of the PC25C were not incorporated within this schedule.

\subsubsection{Lessons Learned}

Future fuel cell testing programs within FCTec, when appropriate, will address the manufacturer's fabrication and test schedule milestones within the program test schedule. This information may not help with the actual delivery date of the unit but it will identify the actions that need to be completed prior to FCTec re- 
ceiving the unit for testing. This approach may assist with adding some contingency to the schedule.

\subsection{Design Drawings for the In-door Ventilation System}

$C T C$ 's initial approach was to fabricate and install the in-door ventilation system for the PC25C. This approach was decided after CTC and ERDC/CERL visited UTC Fuel Cells and reviewed the in-door ventilation system that UTC Fuel Cells was currently using for the PC25C units within their testing facility. UTC Fuel Cells did indicate that a modification to the in-door ventilation design was ongoing and that $C T C$ would receive the design drawings once available. CTC used the information gained from this site visit to support the site preparation schedule and cost estimate.

The revised drawings provided by UTC Fuel Cells revealed that the fabrication and installation complexity of the new in-door ventilation system had significantly increased over UTC Fuel Cells earlier design. CTC's in-house staff could no longer support the fabrication and installation support needed for the new indoor ventilation system.

Therefore, a qualified Heating, Ventilating, Air Conditioning (HVAC) subcontractor was used to fabricate and install the new in-door system. This change resulted in schedule delays and cost increases within the site preparation task.

\subsubsection{Lessons Learned}

Future fuel cell testing programs within FCTec, when appropriate, should consider the following approache concerning the installation of supporting fuel cell systems.

Work directly with the design company to obtain detailed design drawings and/or an engineering estimate of scope and cost of the supporting systems.

\subsection{Thermal Load Bank System}

The final cost of the design, assembly, test and delivery of thermal load bank (TLB) was approximately 2.5 times greater than the preliminary cost estimate. A sub-contractor in support of the preliminary design details developed by CTC and ERDC/CERL provided the initial estimated cost for this system. Several new enhancements/requirements (stainless steel piping, sensors, control devices, 
and safety items) were added to the original design, which impacted this increase.

CTC and ERDC/CERL enhanced the design requirement of the TLB. The added features of the TLB enhanced the capabilities of this system to be used not only for testing and validating fuel cell heat recovery systems but also to be used to support testing and validating of fuel cell stacks.

\subsubsection{Lessons Learned}

Future fuel cell testing programs within FCTec, when appropriate, should consider the following approaches for calculating cost estimates when final design details are not properly defined:

- Request available options in material, data acquisition and controls when receiving a budgetary number from a equipment/system manufacturer.

- Apply a safety factor (contingency \%) to all in-house engineering estimates in support of special equipment that will be manufactured outside of CTC.

\subsection{Test Data Review}

All test data captured in support of the baseline and extended scope testing on the PC25C were transferred to the project FTP site for UTC Fuel Cells and ERDC/CERL review. The initial project schedule identified a 1-week period for UTC Fuel Cells to review the data and provide comments back to CTC regarding the test. Due to the large data files the actual data review process took 2 to 3 weeks to complete. Several times CTC had advanced to the next baseline test only to receive word from UTC Fuel Cells that the previous test would need to be repeated due to improper operating parameters that were identified from the data review and analysis phase.

\subsection{Testing Issues}

CTC installed in-line sensors in support of capturing process data during the test and validation of the PC25C. Problems were encountered that caused replacement of several of the sensors. The task of removing the bad sensors and replacing with new sensors did require ongoing testing to be delayed. The sensors that required replacements during the baseline testing phase of the $\mathrm{PC} 25 \mathrm{C}$ were:

- nine (9) pressure sensors

- four (4) temperature sensors

- two (2) mass flow meters. 
In addition, several components malfunctioned during the normal operation of the $\mathrm{PC} 25 \mathrm{C}$ in support of the baseline testing that required CTC to shut the power plant down and delay testing. A list of the problems encountered during the testing phase are provided below:

- nitrogen fuel line leak inside the PC25C

- replacement of the four (4) cooling module motors

- replacement of the hand operated ball valve within the thermal management loop

- replacement of several capacitors within the inverter.

\subsubsection{Lessons Learned}

Future fuel cell testing program within FCTec, when appropriate, should consider the following approaches for defining the program test plan schedule when test data review is required to determine the status of the test and/or the operating conditions of the fuel cell system:

- Determine actual size of the data file(s) and appropriate format required for the review and analysis phase.

- Work directly with the fuel cell manufacturers to receive the estimated duration and estimate milestones for the completion of the review and analysis.

- Assemble the program test schedule with an option to either repeat the previous test or start the set-up for the next test following the data review and analysis phase.

\subsubsection{Lessons Learned}

Future fuel cell testing program within FCTec will incorporate planned shutdown periods. This planned shutdown should be scheduled at a minimum of every 12 working weeks when testing with a maximum duration of 1 week. It is anticipated that a planned shutdown will provide some contingency within the program test schedule.

\subsection{Vibration Test System}

The final cost of the acquisition of the Vibration Test System was approximately twice the preliminary cost estimate. One major enhancement/requirement was added to the original design in the period from initial cost estimate to actual procurement. The overall capacity of this system was increased from testing $3 \mathrm{~kW}$ fuel cell systems to testing $10 \mathrm{~kW}$ fuel cell systems. This enhancement required a larger vibration test system than had been planned. 
$C T C$ and ERDC/CERL enhanced the design requirement of this system in support of attracting the fuel cell developers of low power systems to FCTec.

\subsubsection{Lessons Learned}

Future equipment cost estimate activities within FCTec will evaluate the current and future needs of the fuel cell technology industry prior to determining estimated cost of planned equipment.

\subsection{Environmental Chamber Test System}

The total cost of the acquisition of the Environmental Chamber Test System was approximately 1.25 times greater than the preliminary cost estimate. One major enhancement/requirement was added to the original design in the period from initial cost estimate to actual procurement. The overall capacity of this system was increased from testing $3 \mathrm{~kW}$ fuel cell systems to testing $10 \mathrm{~kW}$ fuel cell systems. This enhancement required a larger Environmental Chamber Test System than had been planned.

CTC and ERDC/CERL enhanced the design requirement of this system in support of attracting the fuel cell developers of low power systems to FCTec.

\subsubsection{Lessons Learned}

Future equipment cost estimate activities within FCTec will evaluate the current and future needs of the fuel cell technology FCTec prior to determining estimated cost of planned equipment.

\subsection{Summary}

This report fulfills the requirements of the SOW paragraphs 2.9.1 and 2.9.2 FY98 and FY99 Final Report and documents the tasks performed by CTC for the first 2 years of NDCEE Task N.211, U.S. Army ERDC/CERL Fuel Cell Program.

As described within this report, all planned objectives for the first 2 years of this program have been successfully completed. The information presented within this report addresses all the activities completed by CTC with the cooperation of ERDC/CERL to achieve the following objectives:

- The design and construction of the DOD FCTec within the ETF facility at CTC including the acquisition and installation of testing equipment within the FCTec for the support of PC25C testing and evaluation 
- The acquisition and installation of a PC25C with customized capabilities

- The completion of testing within the FCTec to support baseline and performance improvement objectives of the ERDC/CERL fuel cell program

- The acquisition and installation of testing equipment within the FCTec for smaller fuel cell power plant systems.

As a result of the program objectives, the ERDC/CERL has established a National Resource that can provide independent, unbiased testing and validation of fuel cell power plants for military and commercial applications. This test center (FCTec) provides the ERDC/CERL with the capability to significantly support the development and commercialization of fuel cell power plants.

The ERDC/CERL has established funding to continue year three of this program. Future activities planned are consistent with the EDRC/CERL Fuel Cell Program objectives and in general include:

- Enhance the design of the DOD FCTec.

- Continue the test and evaluation activities on the PC25C.

- Procure and install testing equipment to support the test and evaluation of alternative technology fuel cell systems.

- Promote the use of FCTec to the fuel cell developers. 


\section{Appendix B: BT001A Test Plan}

Title: Test Plan FCTP46533

FPS Gas Composition for SN9194

Test BT001A

\begin{tabular}{|c|c|c|c|}
\hline REV. LTR. & AUTHOR & RELEASE NO. & DATE \\
\hline- & Steve Pixton / Scott Kenner & D01PG1717 & 11 Nov 2001 \\
\hline & & & \\
\hline
\end{tabular}

PRODUCT FILE ADDRESS: Test Plan BT001A Test Plan for SN9194 11-06-2001.doc

\begin{tabular}{|c|c|c|c|}
\hline POWER PLANT/PROGRAM & SYSTEM \& TAG NO. & PART NO. & DOCUMENT NO. \\
\hline PC25C & & & FCTP46533 \\
\hline
\end{tabular}

\begin{tabular}{|l|l|l|l|l|}
\hline & REVISION RECORD & & & \\
\hline & & & & \\
\hline & & & & \\
\hline
\end{tabular}

\begin{tabular}{|c|c|c|c|c|}
\hline $\begin{array}{c}\text { DASH NO. } \\
\text { LTR }\end{array}$ & REL NO. & LTR & DESCRIPTION & DATE \\
\hline & - & & Preliminary Draft & 29 Oct 01 \\
\hline & D01PG1717 & & CTC / UTC FUEL CELLS Revisions & 11 Nov 01 \\
\hline
\end{tabular}

\section{Objective}

HDS exit gas samples at various heater band and control thermocouple locations will be captured.

Samples of the inlet natural gas will be taken.

The sample contents will be used for the analysis of sulfur compounds. 


\section{Length of Test}

8- 10 days, single shift

\section{Materials Required}

- 30 6-litre sampling canisters

- Laptop with LDT software.

\section{Ports Location for the Gas Samples}

The gas samples for the HDS outlet gas will be taken at port AP001 (HDS exit after the steam ejector) and AP003 (HDS exit before the steam ejector).

The gas sample for the inlet gas will be taken at any convenient inlet port.

\section{Test Set-Up}

Figure B1 depicts the test configuration. Three additional ILS HTR002 heater bands (numbers 4, 5, and 6 in the figure) are to be installed on the ILS; three of the six total heater bands will be active at any one time during testing.

TE001, TE010, and TE002 will each be used as the heater control thermocouple during portions of the test.

33 additional thermocouples are to be installed per UTC Fuel Cells drawing XFC19433.

Three ON/OFF set-points for HTR002 will be used:

10. $550 / 575^{\circ} \mathrm{F}$

11. $565 / 585^{\circ} \mathrm{F}$

$12.540 / 560{ }^{\circ} \mathrm{F}$

Two power levels will be run:

13. $200 \mathrm{~kW}$

14. $80 \mathrm{~kW}$ 
One sample of the incoming natural gas is required at the start of each new week of testing.

\section{Data Acquisition Parameters}

Table B1. BT001A test, miscellaneous data acquisition parameters.

\begin{tabular}{|l|l|l|}
\hline Outside Temp & Glycol Supply Temp & Glycol Return Temp \\
\hline Hex800 Discharge Air Temp & Nitrogen Mass Flow & Propane Mass Flow \\
\hline Nitrogen Pressure & Natural Gas Mass Flow & Nitrogen Temperature \\
\hline Natural Gas Temperature & Propane Temperature & Natural Gas Pressure \\
\hline Propane Pressure & Inside Temperature & AP401 \\
\hline AP402 & AP403 & AP404 \\
\hline AP405 & Anode Inlet Pressure & Anode Exit Pressure \\
\hline Cross Pressure & & \\
\hline
\end{tabular}

Table B2. BT001A test, thermocouple data acquisition parameters.

\begin{tabular}{|c|c|c|c|c|c|c|}
\hline TE0021A & TE0021B & TE0022A & TE0022B & TE0022C & TE0023A & TE0023B \\
\hline TE0023C & TE0024A & TE0024B & TE0024C & TE0025A & TE0025B & TE0025C \\
\hline TE0025E & TE0026A & TE0026B & TE0026C & TE0027A & TE0027B & TE0027C \\
\hline TE0028A & TE0028B & TE0028C & TE0029A & TE0029B & TE0029C & TE0029E \\
\hline TE0030A & TE0030B & TE0030C & TE0031A & TE0031B & & \\
\hline
\end{tabular}

Table B3. BT001A test, radar data acquisition parameters.

\begin{tabular}{|l|l|l|}
\hline RADAR ANALOG & RADAR CALCULATED & RADAR CONTROL \\
\hline RADAR DI & RADAR DO & RADAR DO CYCLES \\
\hline RADAR INVERTER & RADAR INV DIO & RADAR SEQUENCE \\
\hline
\end{tabular}

\section{Test Program}

A) Table 1 summarizes the test points at which sampling will take place.

B) For each test, label the canister tags as listed in Table 1.Each test condition will require 1, 2 or 3 samples, as indicated in the table, thus label the canister tags $1.1,1.2$, etc, through 16.2. When preparing the sample canisters for overnight shipment, fill out the chain-of-custody record. In the space indicated check the "normal" block for turn around time. 
C) Record the LDT and Data Acquisition parameters at 10-minute intervals during testing and as samples are taken.

D) Testing begins at $80 \mathrm{~kW}$, then increases to $200 \mathrm{~kW}$ per Table B1. The test order between $80 \mathrm{~kW}$ and $200 \mathrm{~kW}$ is not critical to the program so if other considerations require switching the power order it can be done. Stabilization time is critical to all points therefore after a power change a stabilization time of at least $8 \mathrm{hrs}$ is required.

E) The 'Control Temperature During Sample' column of Table B1 refers to TE001, TE010, or TE002, depending on which T/C is indicated to be the Control T/C for each test. To a greater or lesser extent, all of these temperatures cycle from a maximum value to a minimum value. Each sample is to be taken at either the maximum or the minimum in the temperature cycle, as indicated on the table.

F) The baseline tests (nos. 1-4) will collect data at the baseline heater and T/C configuration of the power plant.

G) To change the Control T/C Set Point Range, go to LDT Screen 125, and change the HDS HEATER CONTROL DEADBAND $(\mathrm{L}, \mathrm{U})$ to the values in Table B1.

H) To activate alternate heater bands, FIRST TRIP CIRCUIT BREAKER CB11.

I) BECAUSE OF THE HIGH VOLTAGE (480 V), TEST THE HTR002 TERMINAL BLOCK WITH A VOLTMETER TO ENSURE THERE IS NO VOLTAGE. Next, disconnect and reconnect the appropriate heater bands. This shall be performed by plugging in the three heaters that are to be used according to this test schedule. Reset CB11 and verify that there is voltage on the heater terminal block.

J) To change the Control Thermocouple, FIRST OVERRIDE TE002 TO 550 DEGREES ON LDT SCREEN 99. Then, swap the T/C leads at the T/C connector mounting bracket located on top of the ILS. Once the T/C's have been reconnected, clear the override. LDT will continue to read the TE002 position as the controlling temperature. Since the actual control thermocouple will change during the testing it is essential to maintain a log that documents which thermocouple (TE001, TE010 and TE002) is being read on what channel to avoid confusion during data reduction.

K) WHEN PROGRESSING FROM THE BASELINE TEST TO TEST A, FROM A TO B, AND AGAIN FROM B TO C, THE ILS TEMPERATURES MUST BE ALLOWED TO STABILIZE FOR AT LEAST 8 HRS.

L) At the conclusion of testing, reconnect TE002 as the control T/C, and reset the heater deadband settings to 550 and 575 . 


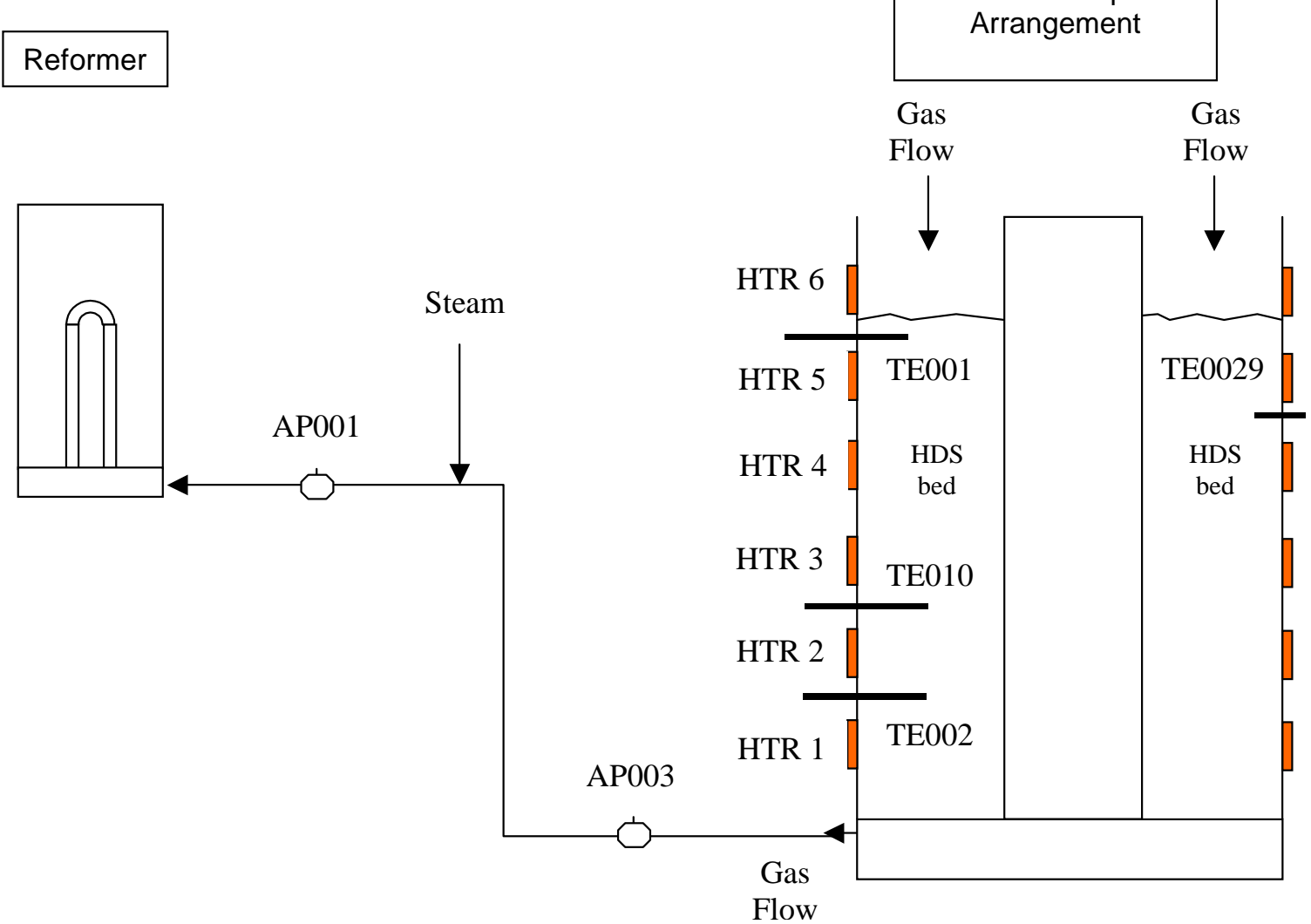

Figure B1. ILS, including heater and thermocouple arrangement. 

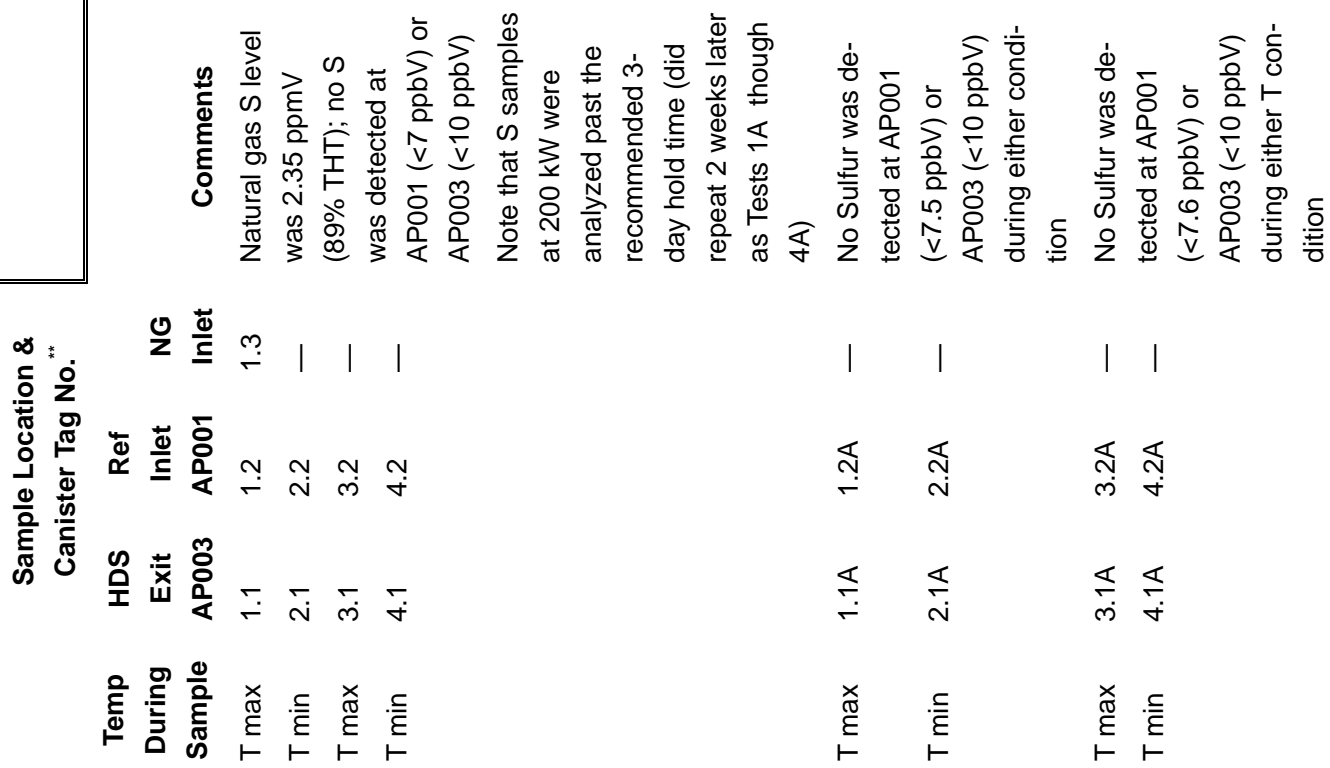

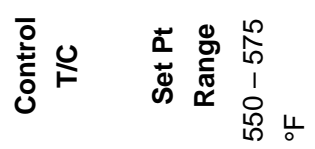

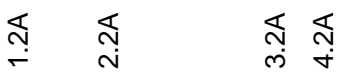

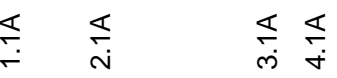

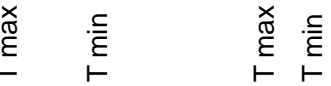

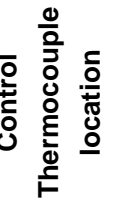

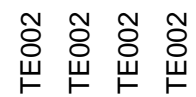

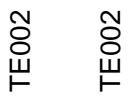

ัญ ชั

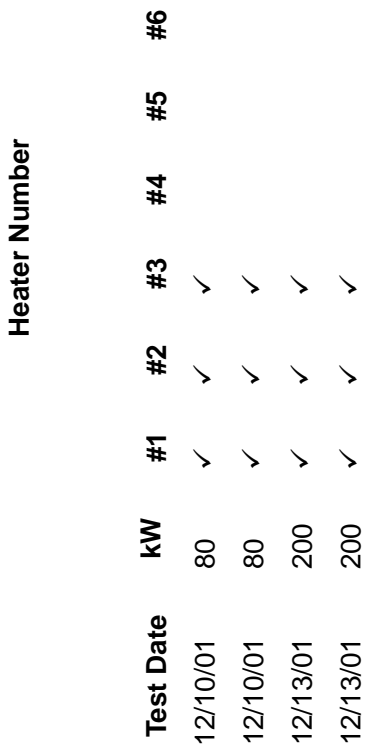

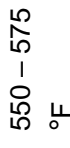

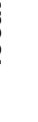

$$
\text { (1) }
$$




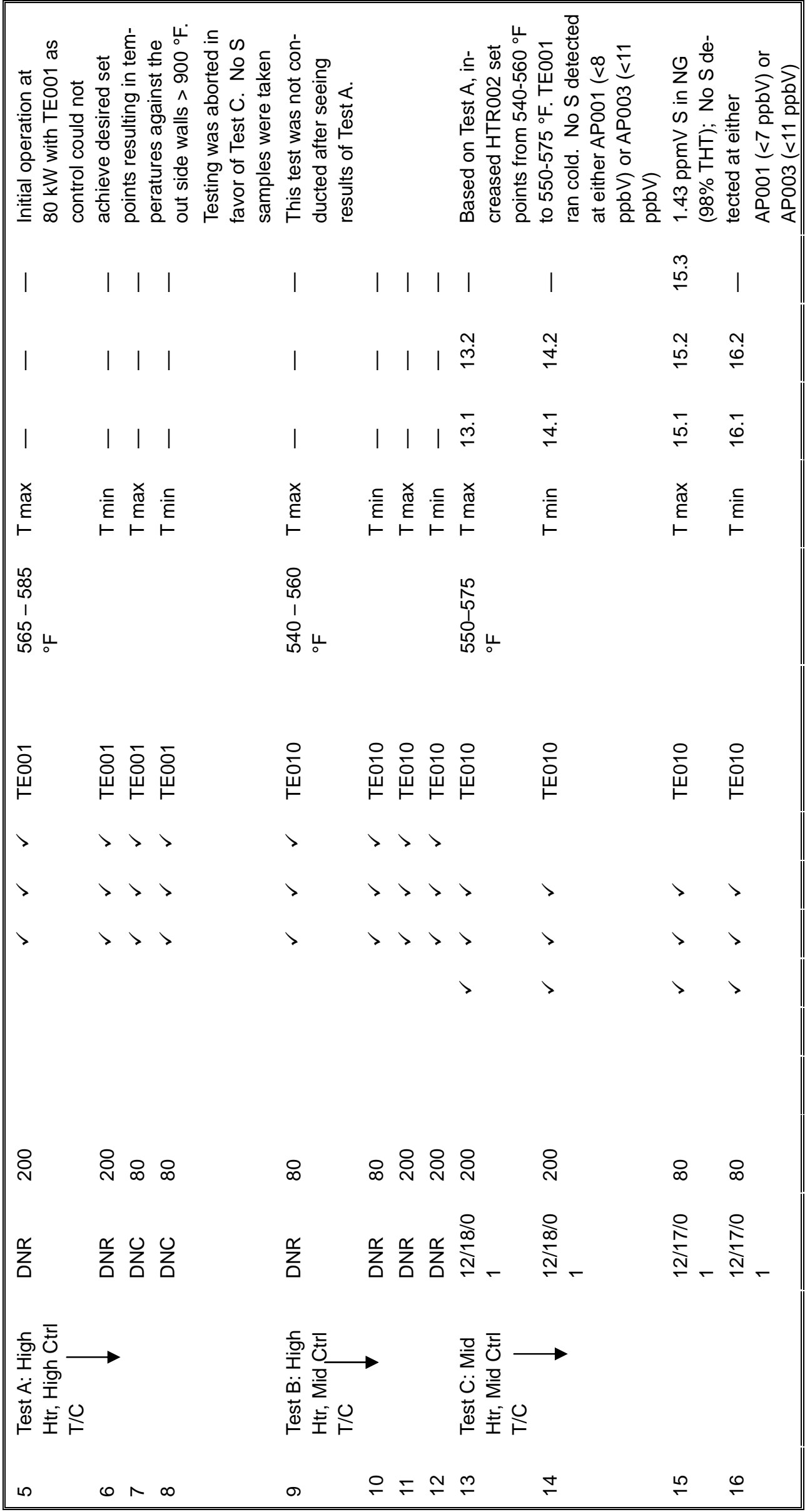




\begin{tabular}{|c|c|c|c|c|c|c|c|}
\hline \multicolumn{2}{|c|}{ 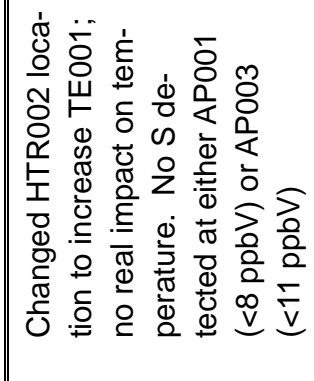 } & \multicolumn{2}{|c|}{ 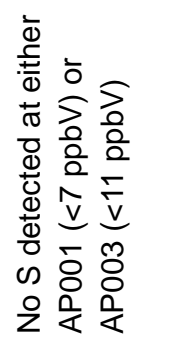 } & \multicolumn{2}{|c|}{ 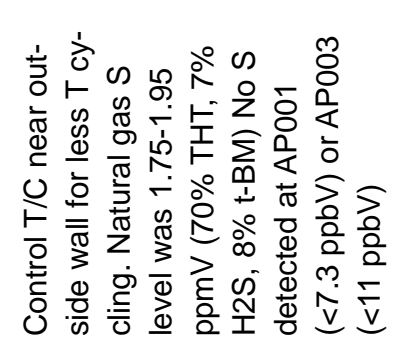 } & \multicolumn{2}{|c|}{ 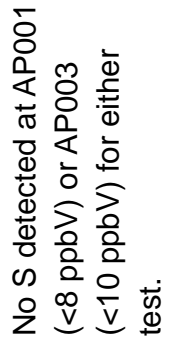 } \\
\hline 1 & $\mid$ & $\mid$ & $\mid$ & $\stackrel{m}{\text { N }}$ & I & I & I \\
\hline$\dot{\vec{H}} \sim$ & $\stackrel{\infty}{\rightarrow} \sim$ & $\stackrel{\infty}{\rightarrow} \sim$ & $\dot{\sim} \sim$ & -் $\sim$ & I & $\ddot{N} \sim$ & $\stackrel{\dot{d}}{N} N$ \\
\hline$\stackrel{\overbrace{}}{\stackrel{-}{二}}$ & $\begin{array}{l}\overrightarrow{-1} \\
\stackrel{\infty}{\rightarrow}\end{array}$ & $\stackrel{\rightarrow}{\rightarrow}$ & $\stackrel{-1}{\stackrel{N}{~}}$ & $\stackrel{-1}{-i}$ & 1 & $\stackrel{\vec{N}}{N}$ & $\stackrel{-}{\stackrel{\sim}{N}}$ \\
\hline $\begin{array}{l}\stackrel{\times}{\Xi} \\
\vdash\end{array}$ & $\begin{array}{l}\stackrel{c}{E} \\
\vdash\end{array}$ & $\begin{array}{l}\stackrel{\times}{\varpi} \\
\stackrel{⺊}{\vdash}\end{array}$ & $\begin{array}{l}\stackrel{.}{E} \\
\vdash\end{array}$ & $\begin{array}{l}\stackrel{x}{\varpi} \\
\stackrel{\leftarrow}{上}\end{array}$ & $\begin{array}{l}\stackrel{\stackrel{\subseteq}{E}}{\vdash} \\
\vdash\end{array}$ & $\begin{array}{l}\stackrel{\times}{\varpi} \\
\stackrel{\vdash}{\vdash}\end{array}$ & $\begin{array}{l}\stackrel{\complement}{\underline{E}} \\
\vdash\end{array}$ \\
\hline 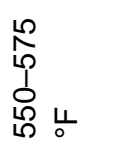 & & & & $\begin{array}{l}8 \\
0 \\
1 \\
0 \\
0 \\
0\end{array}$ & & & \\
\hline $\begin{array}{l}\text { 을 } \\
\text { 岗 }\end{array}$ & $\begin{array}{l}\text { 움 } \\
\text { 岗 }\end{array}$ & $\begin{array}{l}\stackrel{0}{-} \\
\text { 岗 } \\
⺊\end{array}$ & $\begin{array}{l}\text { 옹 } \\
\stackrel{\leftrightarrow}{\mapsto}\end{array}$ & 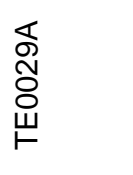 & 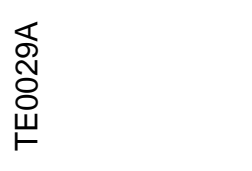 & $\begin{array}{l}\overleftarrow{\$} \\
\text { ठิ } \\
\text { ய }\end{array}$ & $\begin{array}{l}\overleftarrow{\$} \\
\text { Oे } \\
\text { Щ }\end{array}$ \\
\hline$>$ & $>$ & $>$ & $>$ & $>$ & $>$ & $>$ & $>$ \\
\hline$>$ & $>$ & $>$ & $>$ & $>$ & $>$ & $>$ & $>$ \\
\hline$>$ & $>$ & $>$ & $>$ & $>$ & $>$ & $>$ & $>$ \\
\hline$\stackrel{\sim}{\sim}$ & ¿ & 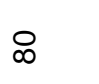 & $\infty$ & $\infty$ & $\infty$ & ¿্ & \& \\
\hline 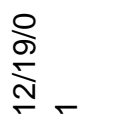 & $\begin{array}{l}\stackrel{\bigcirc}{9} \\
\stackrel{-}{\sim} \\
\neg \\
-1\end{array}$ & $\begin{array}{l}\stackrel{0}{D} \\
\text { Iิ } \\
\text { † }\end{array}$ & 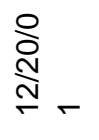 & $\frac{\cong}{\stackrel{\cong}{\infty}}$ & 品 & 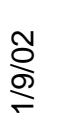 & 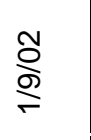 \\
\hline 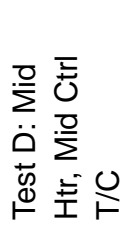 & & & & 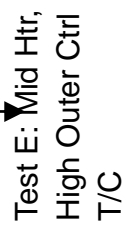 & & & \\
\hline Э & $\underset{\sim}{\infty}$ & $\stackrel{\rightarrow}{\rightarrow}$ & ㅇ & $\vec{N}$ & $\approx$ & $\stackrel{\Re}{N}$ & $\stackrel{\sim}{N}$ \\
\hline
\end{tabular}




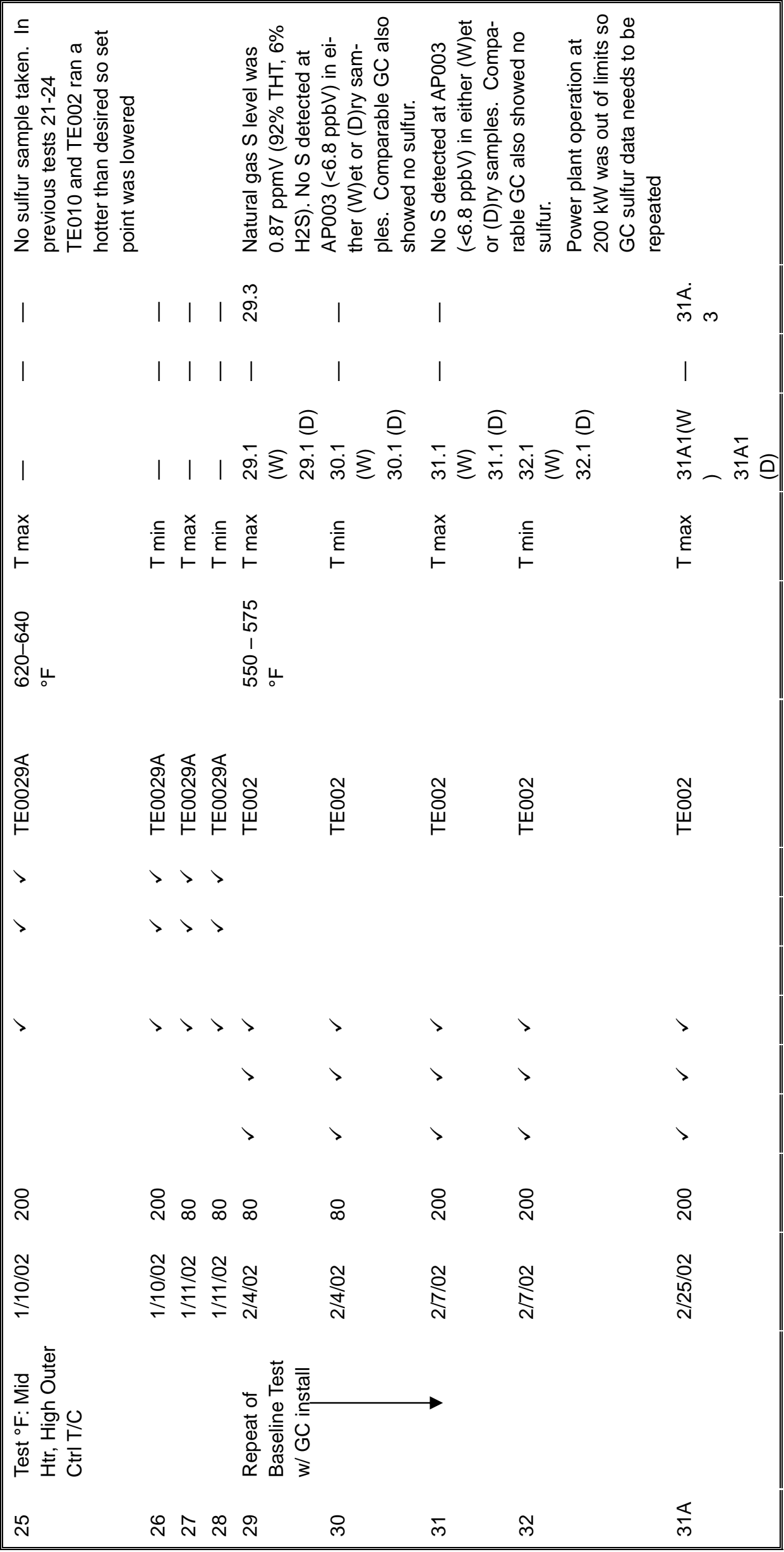




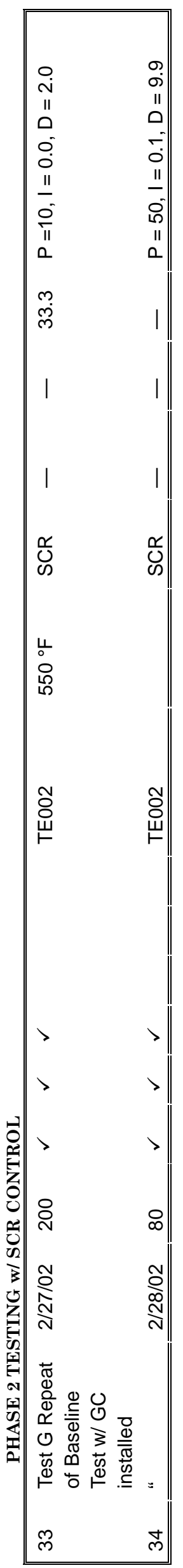

\begin{tabular}{|c|c|c|c|}
\hline 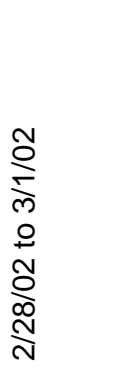 & 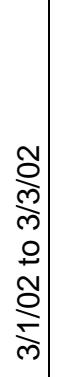 & $\begin{array}{l}8 \\
0 \\
0 \\
11 \\
0 \\
-1 \\
0 \\
11 \\
11 \\
0 \\
-i \\
11 \\
0\end{array}$ & 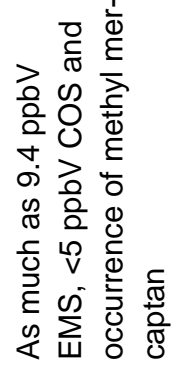 \\
\hline I & 1 & I & 1 \\
\hline | & 1 & | & 1 \\
\hline | & 1 & I & 1 \\
\hline $\begin{array}{l}\frac{\alpha}{U} \\
\text { SO }\end{array}$ & $\begin{array}{l}\frac{r}{U} \\
\mathcal{U}\end{array}$ & $\begin{array}{l}\frac{r}{0} \\
e\end{array}$ & $\begin{array}{l}\frac{r}{0} \\
\text { Un }\end{array}$ \\
\hline $\begin{array}{l}\sqcup \\
\vdots \\
\circ \\
0 \\
0\end{array}$ & & $\begin{array}{l}\sqcup \\
\circ \\
\circ \\
\stackrel{\circ}{0}\end{array}$ & $\begin{array}{l}\text { } \\
\text { 워 } \\
\text { பै }\end{array}$ \\
\hline 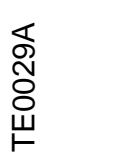 & 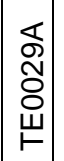 & 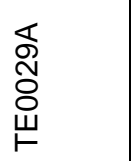 & 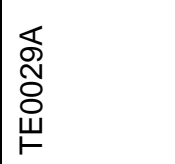 \\
\hline$>$ & $>$ & $>$ & $>$ \\
\hline$>$ & $>$ & $>$ & $>$ \\
\hline$>$ & $>$ & $>$ & $>$ \\
\hline ๑ & ¿্సి & $\infty$ & ঃ \\
\hline $\begin{array}{l}\stackrel{N}{D} \\
\underset{\infty}{N}\end{array}$ & $\frac{\underline{r}}{Z}$ & $\frac{\widetilde{N}}{\stackrel{\text { }}{\text { \} }}} &{\frac{\widetilde{N}}{\stackrel{Ð}{Ð}}} \\
{\hline \text { 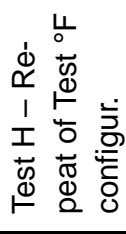 }} &{=} &{\text { 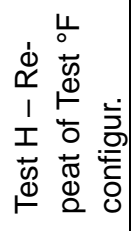 }} &{=} \\
{\hline \stackrel{\text { }}{m}} &{\text { @) }} &{\text { 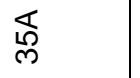 }} &{\text { ఏ్ల }} \\
$\hline
\end{tabular}




\begin{tabular}{|c|c|c|c|c|c|}
\hline 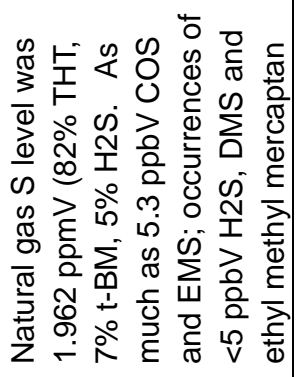 & 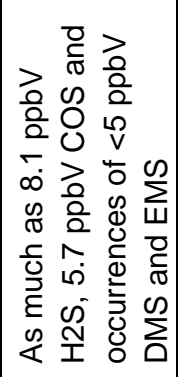 & 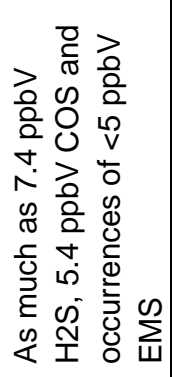 & 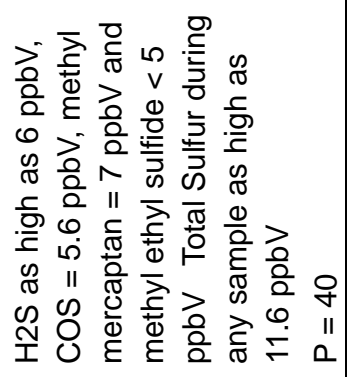 & 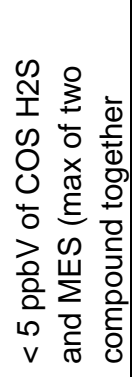 & 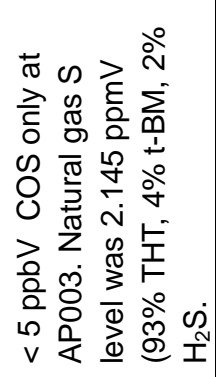 \\
\hline$\stackrel{m}{\stackrel{m}{m}}$ & 1 & I & I & | & $\stackrel{\otimes}{\stackrel{D}{N}} \mathrm{~m}$ \\
\hline I & 1 & I & I & I & 1 \\
\hline 1 & 1 & I & I & 1 & I \\
\hline $\begin{array}{l}\text { r } \\
\text { 心 }\end{array}$ & $\begin{array}{l}\stackrel{r}{u} \\
\stackrel{\omega}{n}\end{array}$ & $\begin{array}{l}\text { r } \\
\text { U }\end{array}$ & $\begin{array}{l}\frac{r}{0} \\
\text { U }\end{array}$ & 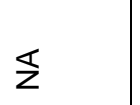 & $\S$ \\
\hline $\begin{array}{l}\text { ㄴ } \\
\text { 웅 }\end{array}$ & $\begin{array}{l}\text { ㅁ } \\
\circ \\
\text { 우 }\end{array}$ & $\begin{array}{l}\text { ․ } \\
\text { 우 }\end{array}$ & $\begin{array}{l}\text { ㄴ } \\
\text { ᄋ } \\
\text { பे }\end{array}$ & 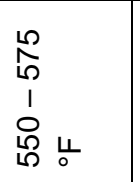 & 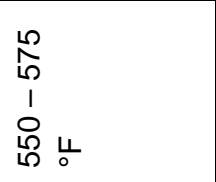 \\
\hline 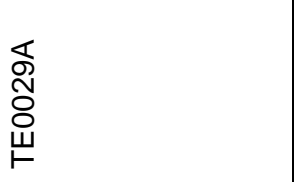 & $\begin{array}{l}\overleftarrow{\$} \\
\text { Oे } \\
\stackrel{\leftrightarrow}{\vdash}\end{array}$ & 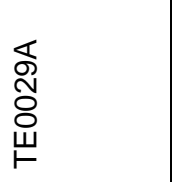 & 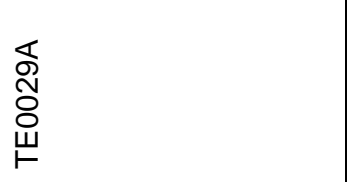 & 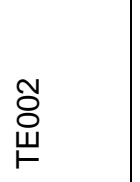 & 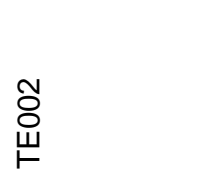 \\
\hline & & $>$ & $>$ & & \\
\hline$>$ & $>$ & $>$ & $>$ & & \\
\hline$>$ & $>$ & $>$ & $>$ & & \\
\hline$>$ & $>$ & & & $>$ & $>$ \\
\hline & & & & $>$ & $>$ \\
\hline & & & & $>$ & $>$ \\
\hline 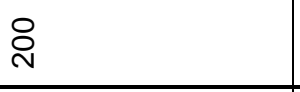 & ○ & $\varnothing$ & $\stackrel{\sim}{~}$ & 尺े & $\infty$ \\
\hline 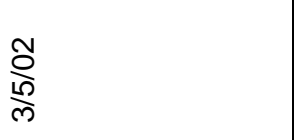 & $\begin{array}{l}\stackrel{Ð}{\varrho} \\
\text { ले }\end{array}$ & $\frac{\cong}{\frac{N}{\rho}}$ & $\frac{\cong}{\stackrel{Ð}{\infty}}$ & 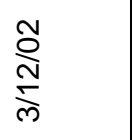 & 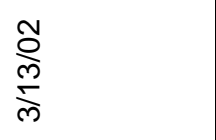 \\
\hline 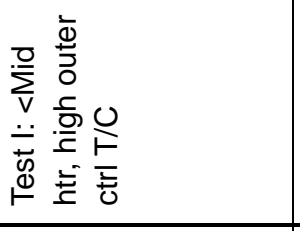 & $=$ & 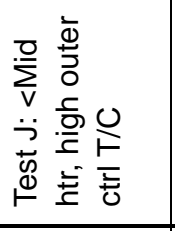 & $=$ & 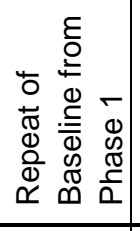 & 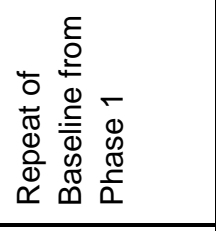 \\
\hline$\hat{m}$ & $\stackrel{\infty}{\infty}$ & ஓి & 우 & $\underset{m}{\stackrel{m}{m}}$ & $\stackrel{\mathscr{D}}{\mathrm{N}}$ \\
\hline
\end{tabular}




\begin{tabular}{|c|c|c|c|c|c|}
\hline 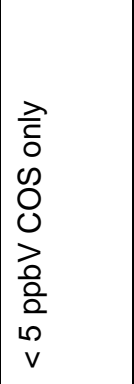 & 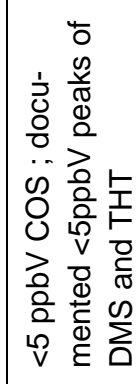 & 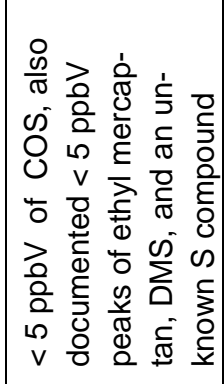 & 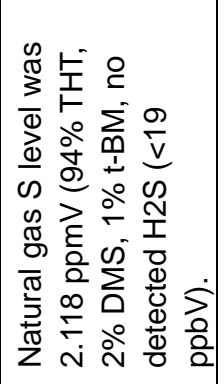 & 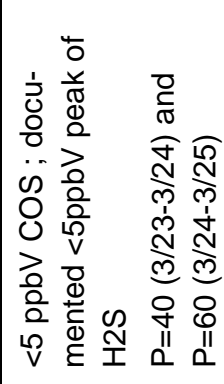 & 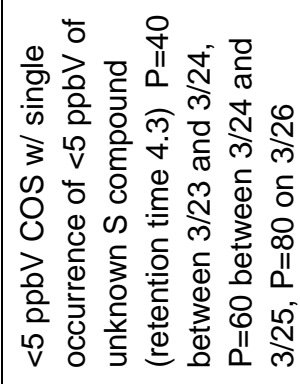 \\
\hline I & I & 1 & ن্ & I & 1 \\
\hline 1 & I & I & | & I & I \\
\hline 1 & I & I & I & I & I \\
\hline$\S$ & $\mathbb{Z}$ & 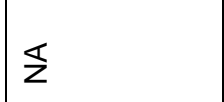 & 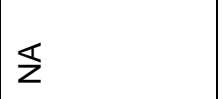 & $\begin{array}{l}\frac{r}{0} \\
\text { c }\end{array}$ & $\begin{array}{l}\text { r } \\
\text { n }\end{array}$ \\
\hline $\begin{array}{l}8 \\
0 \\
1 \\
0 \\
\text { ㄴ } \\
0\end{array}$ & $\begin{array}{l}8 \\
0 \\
1 \\
0 \\
\text { 잉 }\end{array}$ & 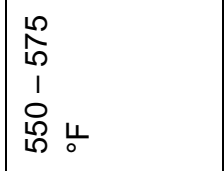 & 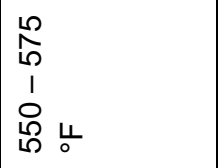 & $\begin{array}{l}\text { ப } \\
\text { 우 }\end{array}$ & $\begin{array}{l}\sqcup \\
\circ \\
\text { ᄋ } \\
0\end{array}$ \\
\hline 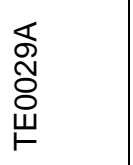 & 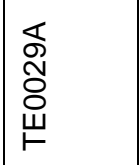 & 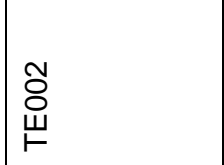 & $\begin{array}{l}\widetilde{O} \\
\text { Фे } \\
\uplus\end{array}$ & 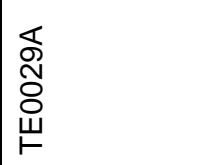 & 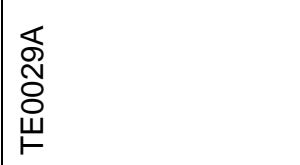 \\
\hline$>$ & $>$ & & & $>$ & $>$ \\
\hline$>$ & $>$ & & & $>$ & $>$ \\
\hline$>$ & $>$ & $>$ & $>$ & $>$ & $>$ \\
\hline & & $>$ & $>$ & & \\
\hline & & $>$ & $>$ & & \\
\hline$\varnothing$ & ঃి & ¿্থ & ○ & ○ & 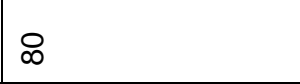 \\
\hline 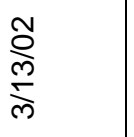 & $\frac{\widetilde{\curvearrowright}}{\stackrel{\sim}{\stackrel{m}{m}}}$ & 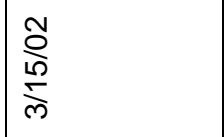 & $\begin{array}{l}\stackrel{\curvearrowright}{\$} \\
\stackrel{-}{m}\end{array}$ & $\frac{\widetilde{N}}{\stackrel{N}{N}}$ & $\begin{array}{l}\stackrel{\curvearrowright}{\mathcal{D}} \\
\stackrel{\text { N }}{\mathrm{N}}\end{array}$ \\
\hline 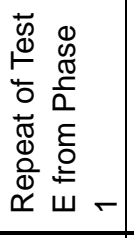 & 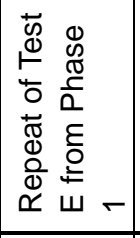 & 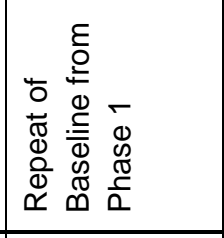 & 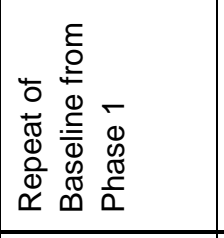 & 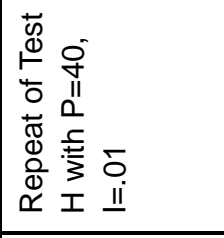 & 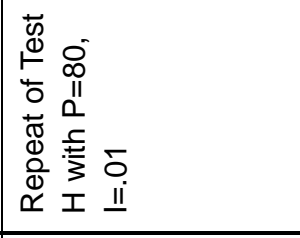 \\
\hline 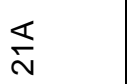 & 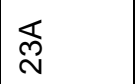 & $\underset{m}{U}$ & O & $\stackrel{\mathscr{m}}{m}$ & U \\
\hline
\end{tabular}




\begin{tabular}{|c|c|c|c|c|c|c|c|}
\hline 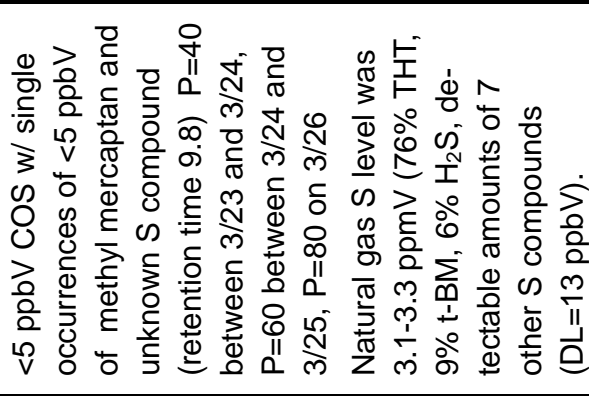 & & 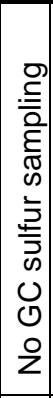 & 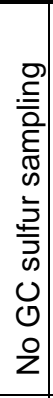 & & 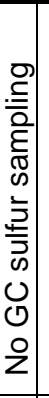 & & 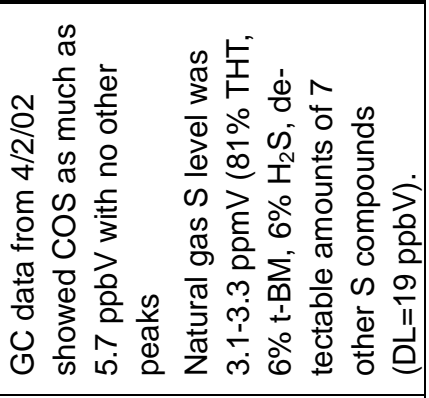 \\
\hline$\dot{m}_{m}$ & I & 1 & 1 & 1 & 1 & $1 \mid$\begin{tabular}{c}
4 \\
\multicolumn{3}{c}{}
\end{tabular} & யّं \\
\hline 1 & 1 & 1 & 1 & 1 & 1 & I & I \\
\hline 1 & I & 1 & 1 & 1 & 1 & I & I \\
\hline 䍃 & 总 & $\begin{array}{l}\frac{r}{0} \\
\stackrel{\omega}{\omega}\end{array}$ & $\begin{array}{l}\frac{r}{0} \\
\text { ws }\end{array}$ & $\begin{array}{l}\stackrel{r}{0} \\
\mathrm{u}\end{array}$ & 䍃 & \begin{tabular}{c|c}
$\frac{r}{0}$ \\
$w$
\end{tabular} & 䍃 \\
\hline $\begin{array}{l}\text { ப. } \\
0 \\
0 \\
0\end{array}$ & \begin{tabular}{l}
\multicolumn{1}{c}{} \\
0 \\
0 \\
6
\end{tabular} & 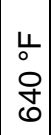 & $\begin{array}{l}\text { ப. } \\
\text { ô } \\
0\end{array}$ & 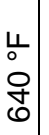 & $\begin{array}{l}\sqcup \\
\vdots \\
0 \\
0 \\
0\end{array}$ & 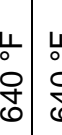 & $\begin{array}{l}\text { ப. } \\
0 \\
0 \\
0\end{array}$ \\
\hline 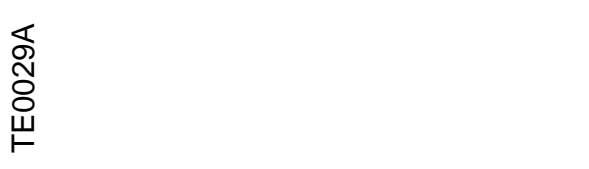 & 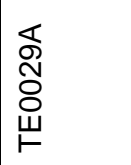 & 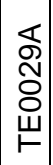 & 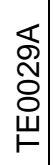 & & 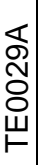 & 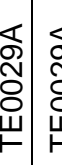 & 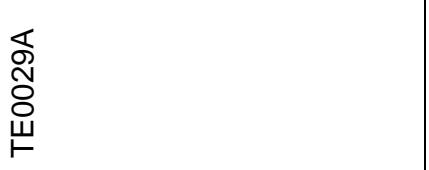 \\
\hline$>$ & $>$ & $>$ & $>$ & $>$ & $>$ & $>$ & $>$ \\
\hline$>$ & $>$ & $>$ & $>$ & $>$ & $>$ & $>$ & $>$ \\
\hline$>$ & $>$ & $>$ & $>$ & $>$ & $>$ & $>>$ & $>$ \\
\hline \& & : & 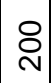 & 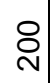 & స్ & స్ & \begin{tabular}{c|c}
$\infty$ & $\S$ \\
\end{tabular} & ¿ \\
\hline 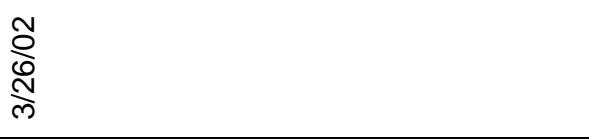 & 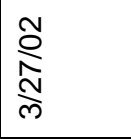 & 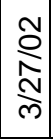 & 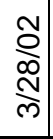 & $\frac{\mathrm{N}}{\mathrm{m}}$ & & 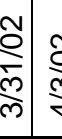 & $\frac{\widetilde{D}}{\frac{\tilde{m}}{\gamma}}$ \\
\hline 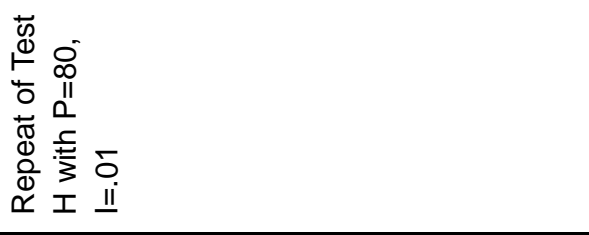 & 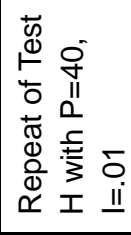 & \begin{tabular}{|c|}
0 \\
0 \\
11 \\
0 \\
0 \\
11 \\
0
\end{tabular} & $\begin{array}{l}0 \\
\text { iI } \\
\text { II } \\
\text { D } \\
\text { II } \\
0\end{array}$ & I & II & 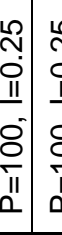 & 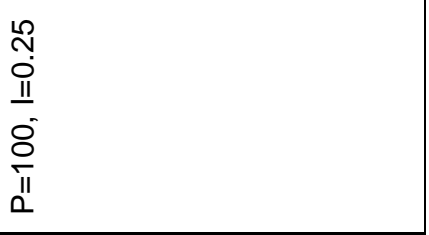 \\
\hline : & :्ల & 足 & $\begin{array}{l}\text { o } \\
\text { I }\end{array}$ & & & 崫 & Ш્ల \\
\hline
\end{tabular}




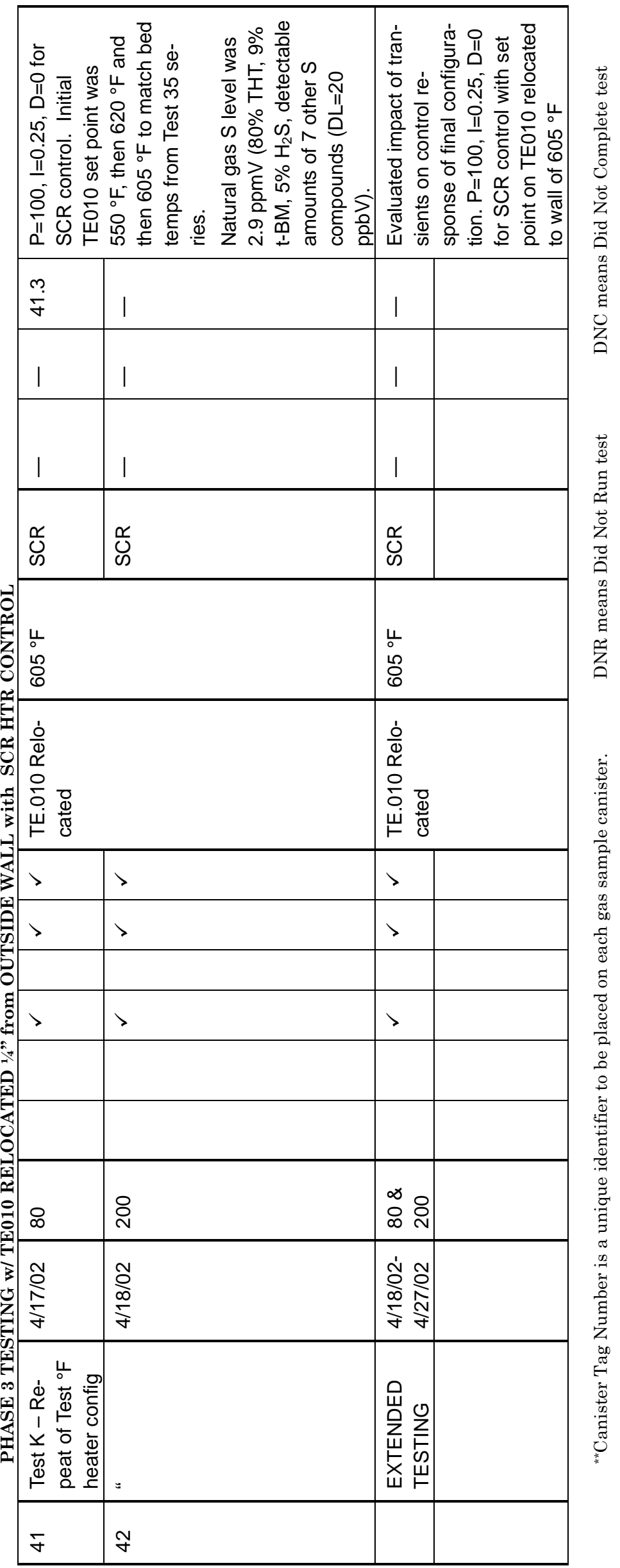




\section{Appendix C: BT001B Test Plan}

Title: Test Plan

Reference Natural Gas for SN9194

Test BT001B

\begin{tabular}{|c|l|l|l|}
\hline REV. LTR. & AUTHOR & RELEASE NO. & DATE \\
\hline- & \multicolumn{1}{|c|}{ LAS } & & 21 Nov 2001 \\
\hline & \multicolumn{3}{l|}{} \\
\hline & \multicolumn{3}{|l|}{} \\
\hline \\
PRODUCT FILE ADDRESS: Test Plan BT001A.DOC & \\
\hline POWER PLANT/PROGRAM & SYSTEM \& TAG NO. & PART NO. & DOCUMENT NO. \\
\hline PC25C & & & $\begin{array}{l}\text { FCTP_BT001B } \\
\text { PAGE 83 OF 5 }\end{array}$ \\
\hline
\end{tabular}

REVISION RECORD

\begin{tabular}{|l|l|l|l|l|}
\hline $\begin{array}{l}\text { DASH NO. } \\
\text { LTR }\end{array}$ & REL NO. & LTR & DESCRIPTION & DATE \\
\hline & & - & ORIGINAL ISSUE & 29 Oct 01 \\
\hline & & & & \\
\hline
\end{tabular}




\section{Objective}

Gas samples at various sample ports (Reformer Process exit, Anode Inlet, Anode Outlet, Cathode Exit, and Burner Exhaust) will be captured. The sample contents will be used for the analysis of light gases including Hydrogen, Carbon Dioxide, Oxygen, Nitrogen, methane, and Carbon Monoxide.

\section{Length of Test}

5 days, single shift

\section{Materials Required}

- GC equipped with gas sampling valve, columns (Hayes separation column and molecular sieve column), and computer control

- Hydrogen (8.5\%) in helium carrier gas

- Dry Gas Meter

- 5L gas sample bags

- Compressed gases (Hydrogen, Nitrogen, Oxygen, Carbon Dioxide, Carbon monoxide, methane)

- Laptop with LDT software.

\section{Port Location for Sampling}

Reformer Process Exit $\left(\mathrm{CO}_{2}, \mathrm{CO}, \mathrm{CH}_{4}, \mathrm{~N}_{2}, \mathrm{H}_{2}, \& \mathrm{O}_{2}\right)$

Anode Inlet $\left(\mathrm{CO}_{2}, \mathrm{CO}, \mathrm{CH}_{4}, \mathrm{~N}_{2}, \mathrm{H}_{2}, \& \mathrm{O}_{2}\right)$

Anode Exit $\left(\mathrm{CO}_{2}, \mathrm{CO}, \mathrm{CH}_{4}, \mathrm{~N}_{2}, \mathrm{H}_{2}, \& \mathrm{O}_{2}\right)$

Cathode Exit $\left(\mathrm{CO}_{2}, \mathrm{CO}, \mathrm{CH}_{4}, \mathrm{~N}_{2}, \mathrm{H}_{2}, \& \mathrm{O}_{2}\right)$

Burner Exhaust $\left(\mathrm{CO}_{2}, \mathrm{CO}, \mathrm{CH}_{4}, \mathrm{~N}_{2}, \mathrm{H}_{2}, \& \mathrm{O}_{2}\right)$ 


\section{Test Setup}

Sampling will be conducted at Idle and at $200 \mathrm{~kW}, 175 \mathrm{~kW}, 150 \mathrm{~kW}, 125 \mathrm{~kW}$, $100 \mathrm{~kW}$, and $50 \mathrm{~kW}$ Power Levels.

\section{Test Program}

\section{Reference Natural Gas Test BT001B}

1.0 Pre-test Start Up Review (No Heat Recovery)

1.1 Fuel Cell in Remote Operation

1.2 Manual Disconnect Switch, (GI Load) Closed, MDS003

1.3 Manual Disconnect Switch, (GC Load) Closed, MDS001

1.4 Grid Connected MCB Closed,MCB002

1.5 Grid Independent MCB Closed, MCB001

1.6 Cooling Module Operational

1.7 Thermal Flow pump Off, PMP 410 \& VFD 413

1.8 Low Grade Heat valves Closed, TLB 412

1.9 High Grade Heat valves Closed, TLB 422 \& TLB 423

1.10 Thermal Load Bank crossover valves Closed, TLB 420 \& TLB 421

1.11 Chilled Water Supply Valve Closed, TLB 425, \& TLB 411

1.12 Nitrogen Injection Valve Closed, FPB 758

2.0 Verify Fuel Cell is operating on Natural Gas

3.0 Verify Fuel Cell at the appropriate Power Level for 2 hrs

4.0 Begin Recording Fuel Cell RADAR Data using a sample rate of 5 minutes.

5.0 Begin Recording Misc. Data for $1 \mathrm{hr}$ using a sample rate of 1 minute unless noted otherwise.

5.1 Cooling Module Information from CTC Sensors

5.1.1 Fluid Flow Temperature In

5.1.2 Fluid Flow Temperature Out

5.1.3 Outside Ambient Air Temperature

5.1.4 Inside Ambient Air Temperature

5.1.5 Discharge Air Temperature

$5.2 \quad$ Cell Stack Assembly (CSA) cross pressure from sensors

5.2.1 PT3000

5.2.2 PT3001

$5.3 \quad$ Thermal Management System Parameters

5.3.1 AP401

5.3.2 AP402

5.3.3 AP403

5.3.4 AP404

5.3.5 AP405

5.4 Natural Gas Temperature and Flow from CTC Sensors

6.0 Sample Gas Analysis at each sample location (5 sites) during 1-hr test

7.0 Capture a RADAR snapshot of all steady-state values and set points

8.0 Stop recording data after $1 \mathrm{hr}$ test or until gas analysis is completed

9.0 Adjust power level to the next net power output setting 
10.0 Wait 2 hrs

11.0 Verify that the required Fuel Cell Power Level has been maintained for 2 hrs and repeat steps 1 through 11 until all testing is completed.

\section{Data Acquisition Parameters}

Table C1. Miscellaneous data acquisition parameters.

\begin{tabular}{|l|l|l|}
\hline Outside Temp & Glycol Supply Temp & Glycol Return Temp \\
\hline Hex800 Discharge Air Temp & Nitrogen Mass Flow & Propane Mass Flow \\
\hline Nitrogen Pressure & Natural Gas Mass Flow & Nitrogen Temperature \\
\hline Natural Gas Temperature & Propane Temperature & Natural Gas Pressure \\
\hline Propane Pressure & Inside Temperature & AP401 Pressure \\
\hline AP402 Pressure & AP403 Pressure & AP404 Pressure \\
\hline AP405 Pressure & Anode Inlet Pressure & Anode Exit Pressure \\
\hline Cross Pressure & & \\
\hline
\end{tabular}

Table C2. Thermocouple data acquisition parameters.

\begin{tabular}{|l|l|l|l|l|l|l|}
\hline TE0021A & TE0021B & TE0022A & TE0022B & TE0022C & TE0023A & TE0023B \\
\hline TE0023C & TE0024A & TE0024B & TE0024C & TE0025A & TE0025B & TE0025C \\
\hline TE0025E & TE0026A & TE0026B & TE0026C & TE0027A & TE0027B & TE0027C \\
\hline TE0028A & TE0028B & TE0028C & TE0029A & TE0029B & TE0029C & TE0029E \\
\hline TE0030A & TE0030B & TE0030C & TE0031A & TE0031B & TE0014A & TE0014B \\
\hline
\end{tabular}

Table C3. Radar data acquisition parameters.

\begin{tabular}{|c|c|c|}
\hline Radar Analog & Radar Calculated & Radar Control \\
\hline Radar Di & Radar Do & Radar Do Cycles \\
\hline Radar Inverter & Radar Inv Dio & Radar Sequence \\
\hline
\end{tabular}




\section{Appendix D: BT001C Test Plan}

STACK EMMISION TESTING

1.0 Daily Start Up Review (No Heat Recovery).

1.1 Fuel Cell in Remote Operation.

1.2 Manual Disconnect Switch, (GI Load) Closed, MDS003.

1.3 Manual Disconnect Switch, (GC Load) Closed, MDS001.

1.4 Grid Connected MCB Closed MCB.

1.5 Grid Independent MCB Closed, MCB001.

1.6 Cooling Module Operational.

1.7 Thermal Flow pump Off, PMP 410 \& VFD 413.

1.8 Low Grade Heat valves Closed, TLB 412

1.9 High Grade Heat valves Closed, TLB 422 \& TLB 423.

1.10 High Grade Heat Crossover valves Closed, TLB 420 \& TLB 421.

1.11 Chilled Water Supply Valve Closed, TLB 425, \& TLB 411.

1.12 Nitrogen Injection Valve Closed, FPB 758.

2.0 Verify Fuel Cell is operating on Natural Gas.

3.0 Verify Fuel Cell power level is at $200 \mathrm{~kW}$ for $2 \mathrm{hrs}$.

4.0 Begin Recording Fuel Cell RADAR Data using a sample rate of 5 min.

5.0 Begin Recording Misc. Data for $1 \mathrm{hr}$ at set power using a sample rate of 1 minute unless noted otherwise.

5.1 Cooling Module Information from CTC Sensors

5.1.1 Fluid Flow Temperature In.

5.1.2 Fluid Flow Temperature Out.

5.1.3 Outside Air Temperature.

5.1.4 Inside Ambient Air Temperature.

5.1.5 Discharge Air Temperature.

5.2 Cell Stack Assembly (CSA) cross pressure from sensors

5.2.1 PT3000

5.2.2 PT3001

5.3 Thermal Management System Parameters

5.3.1 AP401

5.3.2 AP402

5.3.3 AP403

5.3.4 AP404

5.3.5 AP405

5.4 Natural Gas Temperature, and Flow from CTC Sensors

6.0 Perform Emissions monitoring at each of two sites per the following methods:

6.1 Process Exhaust Output Site, (Burner Exhaust)

6.1.1 EPA Method 1 Sample and velocity transverses for stationary sources 
6.1.2 EPA Method 2 Determination of stack gas velocity and volumetric flow rate (Type $\mathrm{S}$ pitot static tube).

6.1.3 EPA Method 3A Determination of Oxygen and Carbon Dioxide in emissions from stationary sources (Instrument Analyzer Procedure)

6.1.4 EPA Method 4 Determination of moisture content in stack gases

6.1.5 EPA Method 7E Determination of Nitrogen Oxide emissions form stationary sources (Instrument Analyzer Procedure)

6.1.6 EPA Method 10 Determination of Carbon Monoxide emissions form stationary sources.

6.1.7 EPA Method 25A Determination of Total Organic Concentration using a Flame Ionization Analyzer.

6.1.8 EPA Method 18 Measurement of Gaseous Organic Compound Emissions by Gas Chromatography

6.2 Ambient Air Sample

6.2.1 EPA Method 1 Sample and velocity transverses for stationary sources

6.2.2 EPA Method 2 Determination of stack gas velocity and volumetric flow rate (Type $\mathrm{S}$ pitot static tube).

6.2.3 EPA Method 3A Determination of Oxygen and Carbon Dioxide in emissions from stationary sources (Instrument Analyzer Procedure)

6.2.4 EPA Method 4 Determination of moisture content in stack gases

6.2.5 EPA Method 7E Determination of Nitrogen Oxide emissions form stationary sources (Instrument Analyzer Procedure)

6.2.6 EPA Method 10 Determination of Carbon Monoxide emissions form stationary sources.

6.2.7 EPA Method 25A Determination of Total Organic Concentration using a Flame Ionization Analyzer.

6.2.8 EPA Method 18 Measurement of Gaseous Organic Compound Emissions by Gas Chromatography

7.0 Perform Emissions monitoring at the following site:

7.1 Cathode Outlet, AP120

7.1.1 EPA Method 3A Determination of Oxygen in emissions from stationary sources (Instrument Analyzer Procedure)

8.0 The analysis shall run for 3-1 hr periods for each power level

9.0 Capture a RADAR snapshot of all steady-state values and set points after the completion of testing

10.0 Stop recording data at the end of test period.

11.0 Decrease power level by $100 \mathrm{~kW}$ net power output.

12.0 Wait 2 hrs

13.0 Verify that fuel cell is at set power for $2 \mathrm{hrs}$.

14.0 Go to step 4 if power level is equal to $100 \mathrm{~kW}$.

15.0 End test, reset power plant to the default operating condition. 


\title{
Appendix E: BT003 Test Plan
}

\author{
Heat Recovery \\ Mapping of High-Grade Heat Exchanger (HEX 490) BT003A \\ 16.0 Start Up Review (Heat Recovery). \\ 16.1 Fuel Cell in Remote Operation \\ 16.2 Manual Disconnect Switch, (GI Load) Open, MDS003 \\ 16.3 Manual Disconnect Switch, (GC Load) Closed, MDS001 \\ 16.4 Grid Connected MCB Closed, MCB002 \\ 16.5 Grid Independent MCB Closed, MCB001 \\ 16.6 Cooling Module Operational \\ 16.7 Thermal Flow pump Off, PMP 410 \& VFD 413 \\ 16.8 Low Grade Heat valves Closed, TLB 412 \\ 16.9 High Grade Heat valves Closed, TLB 422 \& TLB 423 \\ 16.10 Thermal Load Bank crossover valves Closed, TLB 420\&TLB 421 \\ 16.11 Chilled Water Supply Valve Closed, TLB 425 \\ 16.12 Nitrogen Injection Valve Closed, FPB 758 \\ 17.0 Verify Fuel Cell is operating on Natural Gas. \\ 18.0 Verify Fuel Cell power level is at $200 \mathrm{~kW}$ for $2 \mathrm{hrs}$. \\ 19.0 Open Chilled Water supply valve TLB 425 \\ 20.0 Open Flow Control Valve FCV 411 to 25\% open \\ 21.0 Verify CW Flow via visual flow indicator if attended operation \\ 22.0 Verify Low Grade Valve, TLB 412 is Closed \\ 23.0 Verify TLB $422 \&$ TLB 423 are Closed \\ 24.0 Open TLB Crossover Valves (HG mode) TLB 420 \& TLB 421 \\ 25.0 Turn Thermal Flow Pump On, PMP 410 \& VFD 413 \\ 26.0 Set VFD 413 speed (HZ) until FT 419 reads 10 gpm \\ 27.0 Adjust Flow Control Valve FCV 411 until Customer Return Temperature \\ TE 446 stabilizes @ $100^{\circ} \mathrm{F}$ (up to $1 \mathrm{hr}$ ) \\ 28.0 Begin Recording Fuel Cell RADAR Data using a sample rate of $5 \mathrm{~min}$. \\ 29.0 Begin Recording Misc. Data for 15 minutes using a sample rate of $1 \mathrm{~min}$ - \\ ute unless noted otherwise. \\ 29.1 Cooling Module Information from CTC Sensors. \\ 29.1.1 Fluid Flow Temperature In. \\ 29.1.2 Fluid Flow Temperature Out. \\ 29.1.3 Outside Air Temperature. \\ 29.1.4 Inside Ambient Air Temperature. \\ 29.1.5 Discharge Air Temperature. \\ 29.2 Cell Stack Assembly (CSA) cross pressure from sensors. \\ 29.2.1 PT3000
}




\subsubsection{PT3001}

29.3 Thermal Management System Parameters.

29.3.1 AP401

29.3.2 AP402

29.3.3 AP403

29.3.4 AP404

29.3.5 AP405

29.4 Natural Gas Temperature, and Flow from CTC Sensors.

30.0 Begin Recording Thermal Load Bank (TLB) Data for 15 minutes using a sample rate of 1 minute unless noted otherwise.

\begin{tabular}{|l|l|l|}
\hline 15.1 FCV-411 Position Command & 15.10 LG Supply Temperature & 15.19 Fill / Boost Pump \\
\hline 15.2 VFD-413 Speed Command & 15.11 LG Return Temperature & 15.20 TE443 \\
\hline 15.3 LG Supply Pressure & 15.12 HG Supply Temperature & 15.21 TE444 \\
\hline 15.4 LG Return Pressure & 15.13 HG Return Temperature & 15.22 TE445 \\
\hline 15.5 LG Flow Rate & 15.14 VFD Start Command & 15.23 TE446 \\
\hline 15.6 HG Supply Pressure & 15.15 HG/LG Isolation Solenoid \#1 & 15.24 PT447 \\
\hline 15.7 HG Return Pressure & 15.16 HG/LG Isolation Solenoid \#2 & 15.25 PT448 \\
\hline 15.8 HG Flow Rate & 15.17 HG Chilled Water Solenoid & 15.26 PT449 \\
\hline 15.9 FCV-411 Position & 15.18 LG Chilled Water Solenoid & 15.27 PT450 \\
\hline
\end{tabular}

31.0 After 15 minute test, Capture a RADAR snapshot of all steady-state values and setpoints

32.0 Stop recording Misc. \& TLB data after 15 minute test

33.0 Adjust Flow Control Valve FCV 411 until Customer Return Temperature TE 446 stabilizes @ $50^{\circ} \mathrm{F}$ greater than past setting (up to an hour)

34.0 Go to step 13.0 up to and including the $250^{\circ} \mathrm{F}$ setting

35.0 Increase VFD 413 speed in HZ until FT 419 reads 20 gpm greater than past setting

36.0 Go to step 12.0 up to and including the 70 gpm setting

37.0 Decrease Fuel Cell Power Level by $100 \mathrm{~kW}$

38.0 If power is less than $100 \mathrm{~kW}$ go to step 26.0

39.0 Verify Fuel Cell power level is at set power for 2 hrs.

40.0 Go to step 11.0

41.0 End test, reset power plant to the default operating condition.

\section{Heat Recovery}

Mapping of Low-Grade Heat Exchanger (HEX 880) with Water/Glycol Coolant when High-Grade Heat Exchanger (HEX 490) is in use

1.0 Start Up Review (Heat Recovery).

1.1 Fuel Cell in Remote Operation

1.2 Manual Disconnect Switch, (GI Load) Open, MDS003

1.3 Manual Disconnect Switch, (GC Load) Closed, MDS001

1.4 Grid Connected MCB Closed, MCB002

1.5 Grid Independent MCB Closed, MCB001

1.6 Cooling Module Operational 
1.7 Thermal Flow pump Off, PMP 410 \& VFD 413

1.8 Low Grade Heat valves Closed, TLB 412

1.9 High Grade Heat valves Closed, TLB 422 \& TLB 423

1.10 Thermal Load Bank crossover valves Closed, TLB 420\&TLB 421

1.11 Chilled Water Supply Valve Closed, TLB 425

1.12 Nitrogen Injection Valve Closed, FPB 758

2.0 Verify Fuel Cell is operating on Natural Gas.

3.0 Verify Fuel Cell power level is at $200 \mathrm{~kW}$ for $2 \mathrm{hrs}$.

4.0 Open Chilled Water supply valve TLB 425

5.0 Open Flow Control Valve FCV 411 to $25 \%$ open

6.0 Verify CW Flow via visual flow indicator if attended operation

7.0 Open Low Grade Valve, TLB 412

8.0 Verify HOG 442 is $100 \%$ Open. Open TLB 422 \& TLB 423 (Chilled Water to HEX $490(\mathrm{HG}))$

9.0 Verify TLB Crossover Valves are Closed (LG mode), TLB 420 \& TLB 421

10.0 Turn Thermal Flow Pump On, PMP 410 \& VFD 413

11.0 Adjust Flow Control Valve FCV 411 until Customer Return Temperature (CRT) TE 444 approximates $60^{\circ} \mathrm{F}$

12.0 Set VFD 413 speed (HZ) until FT 405 reads the first Customer Flow Rate for the current Customer Return Temperature setting per Table E1 be-

low. Adjustment of FCV 411 will be required to stabilize current CRT (TE 444) setting (up to an hour)

13.0 Begin Recording Fuel Cell RADAR Data using a sample rate of $5 \mathrm{~min}$.

14.0 Begin Recording Misc. Data for 15 minutes using a sample rate of 1 minute unless noted otherwise.

14.1 Cooling Module Information from CTC Sensors.

14.1.1 Fluid Flow Temperature In.

14.1.2 Fluid Flow Temperature Out.

14.1.3 Outside Air Temperature.

14.1.4 Inside Ambient Air Temperature.

14.1.5 Discharge Air Temperature.

14.2 Cell Stack Assembly (CSA) cross pressure from sensors.

14.2.1 PT3000

14.2.2 PT3001

14.3 Thermal Management System Parameters.

14.3.1 AP401

14.3.2 AP402

14.3.3 AP403

14.3.4 AP404

14.3.5 AP405

14.4 Natural Gas Temperature, and Flow from CTC Sensors. 
15.0 Begin Recording Thermal Load Bank (TLB) Data for 15 minutes using a sample rate of 1 minute unless noted otherwise.

\begin{tabular}{|l|l|l|}
\hline 15.1 FCV-411 Position Command & 15.10 LG Supply Temperature & 15.19 Fill / Boost Pump \\
\hline 15.2 VFD-413 Speed Command & 15.11 LG Return Temperature & 15.20 TE443 \\
\hline 15.3 LG Supply Pressure & 15.12 HG Supply Temperature & 15.21 TE444 \\
\hline 15.4 LG Return Pressure & 15.13 HG Return Temperature & 15.22 TE445 \\
\hline 15.5 LG Flow Rate & 15.14 VFD Start Command & 15.23 TE446 \\
\hline 15.6 HG Supply Pressure & 15.15 HG/LG Isolation Solenoid \#1 & 15.24 PT447 \\
\hline 15.7 HG Return Pressure & 15.16 HG/LG Isolation Solenoid \#2 & 15.25 PT448 \\
\hline 15.8 HG Flow Rate & 15.17 HG Chilled Water Solenoid & 15.26 PT449 \\
\hline 15.9 FCV-411 Position & 15.18 LG Chilled Water Solenoid & 15.27 PT450 \\
\hline
\end{tabular}

16.0 After 15 minute test, Capture a RADAR snapshot of all steady-state values and setpoints

17.0 Stop recording Misc. \& TLB data after 15 minute test

18.0 Set VFD 413 speed (HZ) until FT 405 is set at the next Customer Side Flow Rate for the current Customer Side Return Temperature setting per Table E1 below. Adjustment of FCV 411 will be required to stabilize current CRT (TE 444) setting (up to an hour)

19.0 Go to step 13.0 until all Customer Side Flow Rates are completed for the current Customer Side Return Temperature

20.0 Adjust Flow Control Valve FCV 411 until Customer Return Temperature TE 444 is $20^{\circ} \mathrm{F}$ greater than past setting

21.0 Go to step 12.0 up to and including the $160^{\circ} \mathrm{F}$ setting

22.0 Decrease Fuel Cell Power Level by $100 \mathrm{~kW}$

23.0 If power is less than $100 \mathrm{~kW}$ go to step 26.0

24.0 Verify Fuel Cell power level is at set power for $2 \mathrm{hrs}$

25.0 Go to step 11.0.

26.0 End test, reset power plant to the default operating condition.

Table E1. BT003 test, hex 880 test parameters, water/glycol - high grade in use.

\begin{tabular}{|c|c|c|c|c|c|}
\hline $\begin{array}{c}\text { Customer Side } \\
\left.\text { Return Temp ( }{ }^{\circ} \mathrm{F}\right)\end{array}$ & \multicolumn{5}{|c|}{ Customer Side Flow Rate (gpm) } \\
\hline 60 & 5 & 10 & 15 & N/A & N/A \\
\hline 80 & 5 & 10 & 15 & N/A & N/A \\
\hline 100 & 5 & 10 & 15 & 20 & 25 \\
\hline 120 & 5 & 15 & 25 & 45 & 90 \\
\hline 140 & 5 & 15 & 25 & 45 & 90 \\
\hline 160 & 10 & 15 & 25 & 45 & 90 \\
\hline
\end{tabular}




\section{Heat Recovery \\ Mapping of Low-Grade Heat Exchanger (HEX 880) with Water/Glycol Coolant when High-Grade Heat Exchanger (HEX 490) is not in use}

1.0 Start Up Review (Heat Recovery).

1.1 Fuel Cell in Remote Operation

1.2 Manual Disconnect Switch, (GI Load) Open, MDS003

1.3 Manual Disconnect Switch, (GC Load) Closed, MDS001

1.4 Grid Connected MCB Closed, MCB002

1.5 Grid Independent MCB Closed, MCB001

1.6 Cooling Module Operational

1.7 Thermal Flow pump Off, PMP 410 \& VFD 413

1.8 Low Grade Heat valves Closed, TLB 412

1.9 High Grade Heat valves Closed, TLB 422 \& TLB 423

1.10 Thermal Load Bank crossover valves Closed, TLB 420\&TLB 421

1.11 Chilled Water Supply Valve Closed, TLB 425

1.12 Nitrogen Injection Valve Closed, FPB 758

2.0 Verify Fuel Cell is operating on Natural Gas.

3.0 Verify Fuel Cell power level is at $200 \mathrm{~kW}$ for $2 \mathrm{hrs}$.

4.0 Open Chilled Water supply valve TLB 425

5.0 Open Flow Control Valve FCV 411 to 25\% open

6.0 Verify CW Flow via visual flow indicator if attended operation

7.0 Open Low Grade Valve, TLB 412

8.0 Verify TLB $422 \&$ TLB 423 are Closed

9.0 Verify TLB Crossover Valves are Closed (LG mode), TLB 420 \& TLB 421

10.0 Turn Thermal Flow Pump On, PMP 410 \& VFD 413

11.0 Adjust Flow Control Valve FCV 411 until Customer Return Temperature (CRT) TE 444 approximates $60^{\circ} \mathrm{F}$

12.0 Set VFD 413 speed (HZ) until FT 405 reads the first Customer Flow Rate for the current Customer Return Temperature setting per Table below.

Adjustment of FCV 411 will be required to stabilize current CRT (TE 444) setting (up to an hour)

13.0 Begin Recording Fuel Cell RADAR Data using a sample rate of 5 min.

14.0 Begin Recording Misc. Data for 15 minutes using a sample rate of 1 minute unless noted otherwise.

14.1 Cooling Module Information from CTC Sensors.

14.1.1 Fluid Flow Temperature In.

14.1.2 Fluid Flow Temperature Out.

14.1.3 Outside Air Temperature.

14.1.4 Inside Ambient Air Temperature.

14.1.5 Discharge Air Temperature.

14.2 Cell Stack Assembly (CSA) cross pressure from sensors.

14.2.1 PT3000

14.2.2 PT3001

14.3 Thermal Management System Parameters. 14.3.1 AP401 
14.3.2 AP402

14.3.3 AP403

14.3.4 AP404

14.3.5 AP405

14.4 Natural Gas Temperature, and Flow from CTC Sensors.

15.0 Begin Recording Thermal Load Bank (TLB) Data for 15 minutes using a sample rate of 1 minute unless noted otherwise.

\begin{tabular}{|c|c|c|}
\hline 15.1 FCV-411 Position Command & 15.10 LG Supply Temperature & 15.19 Fill / Boost Pump \\
\hline 15.2 VFD-413 Speed Command & 15.11 LG Return Temperature & 15.20 TE443 \\
\hline 15.3 LG Supply Pressure & 15.12 HG Supply Temperature & 15.21 TE444 \\
\hline 15.4 LG Return Pressure & 15.13 HG Return Temperature & 15.22 TE445 \\
\hline 15.5 LG Flow Rate & 15.14 VFD Start Command & 15.23 TE446 \\
\hline 15.6 HG Supply Pressure & 15.15 HG/LG Isolation Solenoid \#1 & 15.24 PT447 \\
\hline 15.7 HG Return Pressure & 15.16 HG/LG Isolation Solenoid \#2 & 15.25 PT448 \\
\hline 15.8 HG Flow Rate & 15.17 HG Chilled Water Solenoid & 15.26 PT449 \\
\hline 15.9 FCV-411 Position & 15.18 LG Chilled Water Solenoid & 15.27 PT450 \\
\hline
\end{tabular}

16.0 After 15 minute test, Capture a RADAR snapshot of all steady-state values and setpoints

17.0 Stop recording Misc. \& TLB data after 15 minute test

18.0 Set VFD 413 speed (HZ) until FT 405 is set at the next Customer Side

Flow Rate for the current Customer Side Return Temperature setting per Table E2 below. Adjustment of FCV 411 will be required to stabilize current CRT (TE 444) setting (up to an hour)

19.0 Go to step 13.0 until all Customer Side Flow Rates are completed for the current Customer Side Return Temperature

20.0 Adjust Flow Control Valve FCV 411 until Customer Return Temperature TE 444 is $20^{\circ} \mathrm{F}$ greater than past setting

21.0 Go to step 12.0 up to and including the $160^{\circ} \mathrm{F}$ setting

22.0 Decrease Fuel Cell Power Level by $100 \mathrm{~kW}$

23.0 If power is less than $100 \mathrm{~kW}$ go to step 26.0

24.0 Verify Fuel Cell power level is at set power for 2 hours

25.0 Go to step 11.0.

26.0 End test, reset power plant to the default operating condition.

Table E2. BT003 test, hex 880 test parameters, water/glycol - high grade not in use

\begin{tabular}{|c|c|c|c|c|}
\hline $\begin{array}{c}\text { Customer Side } \\
\left.\text { Return Temp ( }{ }^{\circ} \mathrm{F}\right)\end{array}$ & \multicolumn{5}{|c|}{ Customer Side Flow Rate (gpm) } \\
\hline 60 & 5 & 10 & 15 & N/A \\
\hline 80 & 5 & 10 & 15 & 20 \\
\hline 100 & 15 & 25 & 45 & 90 \\
\hline 120 & 15 & 25 & 45 & 90 \\
\hline 140 & 15 & 25 & 45 & 90 \\
\hline 160 & 15 & 25 & 45 & 90 \\
\hline
\end{tabular}




\section{Appendix F: BT005A Test Plan}

\section{Outline}

Five (5) total transient tests will be performed on the fuel cell power plant (FCPP). The FCPP will be operated in grid independent mode and configured with a base load for each test. Resistive and inductive loads will be applied individually in steps to the base load. The duration of each load step will be 10 seconds. The step load will then be removed and the base load will be applied for another ten seconds prior to the next step load. The sequence of adding and removing a step load to the base load will be performed as outlined in the five (5) tables provided within this test plan. Data will be captured at high speed for a duration of twenty (20) seconds for each step load (5 seconds at base prior to load step +10 seconds of applied load +5 seconds after step removed). It is anticipated that several of these step loads may cause an overload on the FCPP and that the FCPP will either transfer to idle or shutdown. Each of the five tests will end when either of the following event happenings: shutdown or idle condition or all steps are applied with no mishaps.

\section{Daily Start Up / Pre-Test Review (No Heat Recovery)}

- Fuel Cell in Local Operation

- Manual Disconnect Switch, (GI Load) Closed, MDS003

- Manual Disconnect Switch, (GC Load) Closed, MDS001

- Grid Connected MCB Closed, MCB002

- Grid Independent MCB Closed, MCB001

- Cooling Module Operational

- Thermal Flow pump Off, PMP 410 \& VFD 413

- Low Grade Heat valves Closed, TLB 412

- High Grade Heat valves Closed, TLB 422 \& TLB 423

- Thermal Load Bank crossover valves Closed, TLB 420 \& TLB 421

- Chilled Water Supply Valve Closed, TLB 425

- Verify Nitrogen Injection Valve Closed, FPB 758

- Verify Fuel Cell is operating on Natural Gas

- Verify Fuel Cell is at desired power level. 


\section{Test Procedure}

1.0 Verify Grid Independent loads off status.

2.0 Set up the desired Grid Independent test plan on CDAQ as outlined in tables 1 through 5 . Testing sequence shall begin with test/table 1 and incremented up to test/table 5 .

3.0 Configure CDAQ data recording at $1 / 2$ second update rate for the miscellaneous \& ELB data.

4.0 Set up portable high-speed data acquisition system to capture data at a sampling rate of $\mathbf{1 0 0 0}$ samples/second from the Resistive Load Bank (RLB) and Motor Load Bank (MLB).

5.0 Set up Dranetz 658 Disturbance Analyzer to record power quality data.

6.0 Connect PC to LDT port and select Grid Independent Load - disconnect.

7.0 Connect CTC's CDAQ (RADAR DAQ connection) cable to the LDT port.

8.0 Initiate Test via CDAQ - This sequence will begin the desired test as outlined in tables 1 through 5 within this test plan. The following data acquisition will also be initiated at the start of each test.

8.1 UTC Fuel Cells RADAR data snapshot.

8.2 Miscellaneous \& ELB data acquisition (at $1 / 2$ second update)

8.3 High-speed data acquisition (at 1000 samples/second)

8.4 Dranetz 658 Disturbance Analyzer data recording

9.0 Perform desired test as outlined in tables 1 through 5 within this test plan. This process will be automatically controlled via CDAQ. The following data acquisition shutdown will occur at the end of each test.

9.1 UTC Fuel Cells RADAR data snapshot.

9.2 Miscellaneous \& ELB data acquisition

9.3 High-speed data acquisition

9.4 Dranetz 658 Disturbance Analyzer data recording

10.0 Return to Step 1.0 and perform next test. Five total test required (one per test/table)

11.0 End BT005A testing - reset power plant to the default operating condition.

Table F1. BT005A test, miscellaneous data acquisition parameters.

\begin{tabular}{|c|c|c|}
\hline Fluid Flow Temperature In & Cross pressure & AP401 \\
\hline Fluid Flow Temperature Out & $\begin{array}{c}\text { Inside Ambient Air Tem- } \\
\text { perature }\end{array}$ & AP402 \\
\hline \multirow[t]{5}{*}{$\begin{array}{l}\text { Outside Ambient Air Tem- } \\
\text { perature }\end{array}$} & Discharge Air Temperature & AP403 \\
\hline & & AP404 \\
\hline & & AP405 \\
\hline & & PT3000 \\
\hline & & РТ3001 \\
\hline
\end{tabular}

Table F2. BT005A test, ELB data acquisition parameters status

\begin{tabular}{|c|c|c|c|}
\hline $20 \mathrm{hp} \mathrm{PWM}$ Line Side & $50 \mathrm{hp} \mathrm{SS}$ Line Side & $50 \mathrm{~kW}$ Resistor - A & Fan $4-5 \mathrm{hp}$ \\
\hline $20 \mathrm{hp} \mathrm{PWM} \mathrm{Load} \mathrm{Side}$ & $50 \mathrm{hp}$ SS Load Side & $50 \mathrm{~kW}$ Resistor - B & Pump - $15 \mathrm{hp}$ \\
\hline $20 \mathrm{hp}$ SS Line Side & $50 \mathrm{hp}$ SS Enabler & $50 \mathrm{~kW}$ Resistor - C & \\
\hline
\end{tabular}




\begin{tabular}{|c|c|c|c|}
\hline $20 \mathrm{hp}$ SS Load Side & $5 \mathrm{k}$ W Resistor & $50 \mathrm{~kW}$ Resistor $-\mathrm{D}$ & \\
\hline $20 \mathrm{hp}$ SS Enabler & $10 \mathrm{~kW}$ Resistor & Fan $1-5 \mathrm{hp}$ & \\
\hline $20 \mathrm{hp}$ SS Starter & $20 \mathrm{~kW}$ Resistor - A & Fan $2-5 \mathrm{hp}$ & \\
\hline $50 \mathrm{hp}$ SS Starter & $20 \mathrm{~kW}$ Resistor - B & Fan $3-5 \mathrm{hp}$ & \\
\hline
\end{tabular}

Table F3. BT005A test, ELB data acquisition parameters values.

\begin{tabular}{|l|l|l|}
\hline L1-N Voltage & L2-N Voltage & L3-N Voltage \\
\hline RLB L1 Current & RLB L2 Current & RLB L3 Current \\
\hline MLB KWattmeter & & \\
\hline
\end{tabular}

Table F4. BT005A test, high speed data acquisition parameters.

\begin{tabular}{|l|l|l|}
\hline MLB Phase 1 - Instant. Amps & RLB Phase 1 - RMS Amps & Phase 3 - L/N Instant. Volts \\
\hline MLB Phase 2 - Instant. Amps & RLB Phase 2 - RMS Amps & Phase 1 - L/N RMS Volts \\
\hline MLB Phase 3 - Instant. Amps & RLB Phase 3 - RMS Amps & Phase 2 - L/N RMS Volts \\
\hline MLB kW & Phase 1 - L/N Instant. Volts & Phase 3 - L/N RMS Volts \\
\hline Stack - DC Instant. volts & Phase 2 - L/N Instant. Volts & \\
\hline
\end{tabular}

Table F5. BT005A test/table 1 as tested format.

\begin{tabular}{|c|c|c|l|l|c|}
\hline \multicolumn{7}{|c|}{ Base Load - 0 kW } \\
\hline & & & & Total Test \\
Steps & Load Step & Comments & Load Type & $\begin{array}{c}\text { Time } \\
\text { (seconds) }\end{array}$ & (seconds) \\
\hline
\end{tabular}




\begin{tabular}{|c|c|c|c|c|c|}
\hline \multicolumn{6}{|c|}{ Base Load - 0 kW } \\
\hline Steps & Load Step & Comments & Load Type & $\begin{array}{c}\text { Duration } \\
\text { (seconds) }\end{array}$ & $\begin{array}{l}\text { Total Test } \\
\text { Time } \\
\text { (seconds) }\end{array}$ \\
\hline 1 & 0 & Base load & None & 10 & 10 \\
\hline 2 & $50 \mathrm{~kW}$ & $50 \mathrm{~kW}$ total & Resistive & 10 & 20 \\
\hline 3 & 0 & Base load & None & 10 & 30 \\
\hline 4 & 100 kW & $100 \mathrm{~kW}$ total & Resistive & 10 & 40 \\
\hline 5 & 0 & Base load & None & 10 & 50 \\
\hline 6 & $150 \mathrm{~kW}$ & $150 \mathrm{~kW}$ total & Resistive & 10 & 60 \\
\hline 7 & 0 & Base load & None & 10 & 70 \\
\hline 8 & $5 \mathrm{hp}$ & $\begin{array}{c}\text { Base load }+ \text { hp } \\
\text { Line to Line motor start }\end{array}$ & Inductive & 10 & 80 \\
\hline 9 & 0 & Base load & None & 10 & 90 \\
\hline 10 & $10 \mathrm{hp}$ & $\begin{array}{l}\text { Base load }+\mathrm{hp} \\
\text { Line to Line motor starts } \\
\text { Two motor combination }\end{array}$ & Inductive & 10 & 100 \\
\hline 11 & 0 & Base load & None & 10 & 110 \\
\hline 12 & $15 \mathrm{hp}$ & $\begin{array}{c}\text { Base load + hp } \\
\text { Line to Line motor start }\end{array}$ & Inductive & 10 & 120 \\
\hline 13 & 0 & Base load & None & 10 & 130 \\
\hline 14 & $20 \mathrm{hp}$ & $\begin{array}{c}\text { Base load + hp } \\
\text { Soft Start motor start }\end{array}$ & Inductive & 10 & 140 \\
\hline 15 & 0 & Base load & None & 10 & 150 \\
\hline 16 & $20 \mathrm{hp}$ & $\begin{array}{c}\text { Base load + hp } \\
\text { Line to Line motor start }\end{array}$ & Inductive & 10 & 160 \\
\hline 17 & 0 & Base load & None & 10 & 170 \\
\hline 18 & $25 \mathrm{hp}$ & $\begin{array}{l}\text { Base load }+\mathrm{hp} \\
\text { Line to Line motor starts } \\
\text { Three motor combination }\end{array}$ & Inductive & 10 & 180 \\
\hline 19 & 0 & Base load & None & 10 & 190 \\
\hline 20 & $30 \mathrm{hp}$ & $\begin{array}{l}\text { Base load }+\mathrm{hp} \\
\text { Line to Line motor starts } \\
\text { Four motor combination }\end{array}$ & Inductive & 10 & 200 \\
\hline 21 & 0 & Base load & None & 10 & 210 \\
\hline 22 & $50 \mathrm{hp}$ & $\begin{array}{c}\text { Base load }+\mathrm{hp} \\
\text { Soft Start motor start }\end{array}$ & Inductive & 10 & 220 \\
\hline 23 & 0 & Base load & None & 10 & 230 \\
\hline End & & & & & \\
\hline
\end{tabular}


Table F6. BT005A test/table 2 as tested format.

\begin{tabular}{|c|c|c|c|c|c|}
\hline \multicolumn{6}{|c|}{ Base Load - $50 \mathrm{~kW}$} \\
\hline Steps & Load Step & Comments & Load Type & $\begin{array}{c}\text { Duration } \\
\text { (seconds) }\end{array}$ & $\begin{array}{l}\text { Total Test } \\
\text { Time } \\
\text { (seconds) }\end{array}$ \\
\hline 1 & $50 \mathrm{~kW}$ & Base load & Resistive & 10 & 10 \\
\hline 2 & $50 \mathrm{~kW}$ & $100 \mathrm{~kW}$ total & Resistive & 10 & 20 \\
\hline 3 & $50 \mathrm{~kW}$ & Base load & Resistive & 10 & 30 \\
\hline 4 & $100 \mathrm{~kW}$ & $150 \mathrm{~kW}$ total & Resistive & 10 & 40 \\
\hline 5 & $50 \mathrm{~kW}$ & Base load & Resistive & 10 & 50 \\
\hline 6 & $150 \mathrm{~kW}$ & $200 \mathrm{~kW}$ total & Resistive & 10 & 60 \\
\hline 7 & $50 \mathrm{~kW}$ & Base load & Resistive & 10 & 70 \\
\hline 8 & $5 \mathrm{hp}$ & $\begin{array}{c}\text { Base load + hp } \\
\text { Line to Line motor start }\end{array}$ & $\begin{array}{c}\text { Inductive } \\
\text { \& Resistive }\end{array}$ & 10 & 100 \\
\hline 9 & $50 \mathrm{~kW}$ & Base load & Resistive & 10 & 110 \\
\hline 10 & $10 \mathrm{hp}$ & $\begin{array}{l}\text { Base load }+\mathrm{hp} \\
\text { Line to Line motor starts } \\
\text { Two motor combination }\end{array}$ & $\begin{array}{c}\text { Inductive } \\
\text { \& Resistive }\end{array}$ & 10 & 120 \\
\hline 11 & $50 \mathrm{~kW}$ & Base load & Resistive & 10 & 130 \\
\hline 12 & $15 \mathrm{hp}$ & $\begin{array}{c}\text { Base load }+ \text { hp } \\
\text { Line to Line motor start }\end{array}$ & $\begin{array}{c}\text { Inductive } \\
\text { \& Resistive }\end{array}$ & 10 & 140 \\
\hline 13 & $50 \mathrm{~kW}$ & Base load & Resistive & 10 & 150 \\
\hline 14 & $20 \mathrm{hp}$ & $\begin{array}{c}\text { Base load + hp } \\
\text { Soft Start motor start }\end{array}$ & $\begin{array}{l}\text { Inductive } \\
\text { \& Resistive }\end{array}$ & 10 & 160 \\
\hline 15 & $50 \mathrm{~kW}$ & Base load & Resistive & 10 & 170 \\
\hline 16 & $20 \mathrm{hp}$ & $\begin{array}{c}\text { Base load }+ \text { hp } \\
\text { Line to Line motor start }\end{array}$ & $\begin{array}{c}\text { Inductive } \\
\text { \& Resistive }\end{array}$ & 10 & 180 \\
\hline 17 & $50 \mathrm{~kW}$ & Base load & Resistive & 10 & 190 \\
\hline 18 & $25 \mathrm{hp}$ & $\begin{array}{l}\text { Base load }+\mathrm{hp} \\
\text { Line to Line motor starts } \\
\text { Three motor combination }\end{array}$ & $\begin{array}{l}\text { Inductive } \\
\text { \& Resistive }\end{array}$ & 10 & 200 \\
\hline 19 & $50 \mathrm{~kW}$ & Base load & Resistive & 10 & 210 \\
\hline 20 & $30 \mathrm{hp}$ & $\begin{array}{l}\text { Base load }+\mathrm{hp} \\
\text { Line to Line motor starts } \\
\text { Four motor combination }\end{array}$ & $\begin{array}{c}\text { Inductive } \\
\text { \& Resistive }\end{array}$ & 10 & 220 \\
\hline 21 & $50 \mathrm{~kW}$ & Base load & Resistive & 10 & 230 \\
\hline 22 & $50 \mathrm{hp}$ & $\begin{array}{c}\text { Base load + hp } \\
\text { Soft Start motor start }\end{array}$ & $\begin{array}{l}\text { Inductive } \\
\text { \& Resistive }\end{array}$ & 10 & 240 \\
\hline 23 & $50 \mathrm{~kW}$ & Base load & Resistive & 10 & 250 \\
\hline 24 & 0 & 0 & 0 & 10 & 260 \\
\hline End & & & & & \\
\hline
\end{tabular}


Table F7. BT005A test/table 3 as tested format.

\begin{tabular}{|c|c|c|c|c|c|}
\hline \multicolumn{6}{|c|}{ Base Load - $100 \mathrm{~kW}$} \\
\hline Steps & Load Step & Comments & Load Type & $\begin{array}{c}\text { Duration } \\
\text { (seconds) }\end{array}$ & $\begin{array}{c}\text { Total Test Time } \\
\text { (seconds) }\end{array}$ \\
\hline 1 & $100 \mathrm{~kW}$ & Base load & Resistive & 10 & 10 \\
\hline 2 & $50 \mathrm{~kW}$ & $150 \mathrm{~kW}$ total & Resistive & 10 & 20 \\
\hline 3 & $100 \mathrm{~kW}$ & Base load & Resistive & 10 & 30 \\
\hline 4 & $80 \mathrm{~kW}$ & $180 \mathrm{~kW}$ total & Resistive & 10 & 40 \\
\hline 5 & $100 \mathrm{~kW}$ & Base load & Resistive & 10 & 50 \\
\hline 6 & $100 \mathrm{~kW}$ & $200 \mathrm{~kW}$ total & Resistive & 10 & 60 \\
\hline 7 & $100 \mathrm{~kW}$ & Base load & Resistive & 10 & 70 \\
\hline 8 & $5 \mathrm{hp}$ & $\begin{array}{c}\text { Base load }+\mathrm{hp} \\
\text { Line to Line motor start }\end{array}$ & $\begin{array}{l}\text { Inductive } \\
\text { \& Resistive }\end{array}$ & 10 & 80 \\
\hline 9 & $100 \mathrm{~kW}$ & Base load & Resistive & 10 & 90 \\
\hline 10 & $10 \mathrm{hp}$ & $\begin{array}{l}\text { Base load }+ \text { hp } \\
\text { Line to Line motor starts } \\
\text { Two motor combination }\end{array}$ & $\begin{array}{l}\text { Inductive } \\
\text { \& Resistive }\end{array}$ & 10 & 100 \\
\hline 11 & $100 \mathrm{~kW}$ & Base load & Resistive & 10 & 110 \\
\hline 12 & $15 \mathrm{hp}$ & $\begin{array}{c}\text { Base load }+\mathrm{hp} \\
\text { Line to Line motor start }\end{array}$ & $\begin{array}{c}\text { Inductive } \\
\text { \& Resistive }\end{array}$ & 10 & 120 \\
\hline 13 & $100 \mathrm{~kW}$ & Base load & Resistive & 10 & 130 \\
\hline 14 & $20 \mathrm{hp}$ & $\begin{array}{c}\text { Base load + hp } \\
\text { Soft Start motor start }\end{array}$ & $\begin{array}{c}\text { Inductive } \\
\text { \& Resistive }\end{array}$ & 10 & 140 \\
\hline 15 & $100 \mathrm{~kW}$ & Base load & Resistive & 10 & 150 \\
\hline 16 & $20 \mathrm{hp}$ & $\begin{array}{c}\text { Base load }+ \text { hp } \\
\text { Line to Line motor start }\end{array}$ & $\begin{array}{c}\text { Inductive } \\
\text { \& Resistive }\end{array}$ & 10 & 160 \\
\hline 17 & $100 \mathrm{~kW}$ & Base load & Resistive & 10 & 170 \\
\hline 18 & $25 \mathrm{hp}$ & $\begin{array}{l}\text { Base load }+\mathrm{hp} \\
\text { Line to Line motor starts } \\
\text { Three motor combination }\end{array}$ & $\begin{array}{l}\text { Inductive } \\
\text { \& Resistive }\end{array}$ & 10 & 180 \\
\hline 19 & $100 \mathrm{~kW}$ & Base load & Resistive & 10 & 190 \\
\hline 20 & $30 \mathrm{hp}$ & $\begin{array}{l}\text { Base load }+ \text { hp } \\
\text { Line to Line motor starts } \\
\text { Four motor combination }\end{array}$ & $\begin{array}{l}\text { Inductive } \\
\text { \& Resistive }\end{array}$ & 10 & 200 \\
\hline 21 & $100 \mathrm{~kW}$ & Base load & Resistive & 10 & 210 \\
\hline 22 & $50 \mathrm{hp}$ & $\begin{array}{c}\text { Base load + hp } \\
\text { Soft Start motor start }\end{array}$ & $\begin{array}{c}\text { Inductive } \\
\text { \& Resistive } \\
\end{array}$ & 15 & 220 \\
\hline 23 & $100 \mathrm{~kW}$ & Base load & Resistive & 10 & 230 \\
\hline 24 & $50 \mathrm{hp}$ & $\begin{array}{c}\text { Base load }+\mathrm{hp} \\
\text { Line to Line motor start }\end{array}$ & $\begin{array}{l}\text { Inductive } \\
\text { \& Resistive }\end{array}$ & 15 & 240 \\
\hline 25 & 100 kW & Base load & Resistive & 10 & 250 \\
\hline End & & & & & \\
\hline
\end{tabular}


Table F8. BT005A test/table 4 as tested format.

\begin{tabular}{|c|c|c|c|c|c|}
\hline \multicolumn{6}{|c|}{ Base Load - $150 \mathrm{~kW}$} \\
\hline Steps & Load Step & Comments & Load Type & $\begin{array}{l}\text { Duration } \\
\text { (seconds) }\end{array}$ & $\begin{array}{c}\text { Total Test Time } \\
\text { (seconds) }\end{array}$ \\
\hline 1 & 150 kW & Base load & Resistive & 10 & 10 \\
\hline 2 & $100 \mathrm{~kW}$ & Reduced load & Resistive & 10 & 20 \\
\hline 3 & $180 \mathrm{~kW}$ & $180 \mathrm{~kW}$ total & Resistive & 10 & 30 \\
\hline 4 & $200 \mathrm{~kW}$ & $200 \mathrm{~kW}$ total & Resistive & 10 & 40 \\
\hline 5 & $100 \mathrm{~kW}$ & Reduced load & Resistive & 10 & 50 \\
\hline 6 & $150 \mathrm{~kW}$ & Base load & Resistive & 10 & 60 \\
\hline 7 & $30 \mathrm{~kW}$ & $180 \mathrm{~kW}$ total & Resistive & 10 & 70 \\
\hline 8 & $150 \mathrm{~kW}$ & Base load & Resistive & 10 & 80 \\
\hline 9 & $50 \mathrm{~kW}$ & $200 \mathrm{~kW}$ total & Resistive & 10 & 90 \\
\hline 10 & $100 \mathrm{~kW}$ & Base Load & Resistive & 10 & 100 \\
\hline 11 & $150 \mathrm{~kW}$ & Base load & Resistive & 10 & 110 \\
\hline 12 & $30 \mathrm{~kW}$ & $180 \mathrm{~kW}$ total & Resistive & 10 & 120 \\
\hline 13 & $150 \mathrm{~kW}$ & Base load & Resistive & 10 & 130 \\
\hline 14 & $50 \mathrm{~kW}$ & $200 \mathrm{~kW}$ total & Resistive & 10 & 140 \\
\hline 15 & $150 \mathrm{~kW}$ & Base load & Resistive & 10 & 150 \\
\hline 16 & $5 \mathrm{hp}$ & $\begin{array}{c}\text { Base load }+\mathrm{hp} \\
\text { Line to Line motor start }\end{array}$ & $\begin{array}{c}\text { Inductive } \\
\text { \& Resistive }\end{array}$ & 10 & 160 \\
\hline 17 & $150 \mathrm{~kW}$ & Base load & Resistive & 10 & 170 \\
\hline 18 & $10 \mathrm{hp}$ & $\begin{array}{l}\text { Base load }+\mathrm{hp} \\
\text { Line to Line motor starts } \\
\text { Two motor combination }\end{array}$ & $\begin{array}{l}\text { Inductive } \\
\text { \& Resistive }\end{array}$ & 10 & 180 \\
\hline 19 & $150 \mathrm{~kW}$ & Base load & Resistive & 10 & 190 \\
\hline 20 & 15 hp & $\begin{array}{c}\text { Base load }+ \text { hp } \\
\text { Line to Line motor start }\end{array}$ & $\begin{array}{l}\text { Inductive } \\
\text { \& Resistive }\end{array}$ & 10 & 200 \\
\hline 21 & $150 \mathrm{~kW}$ & Base load & Resistive & 10 & 210 \\
\hline 22 & $20 \mathrm{hp}$ & $\begin{array}{c}\text { Base load + hp } \\
\text { Soft Start motor start }\end{array}$ & $\begin{array}{l}\text { Inductive } \\
\text { \& Resistive }\end{array}$ & 10 & 220 \\
\hline 23 & $150 \mathrm{~kW}$ & Base load & Resistive & 10 & 230 \\
\hline 24 & $20 \mathrm{hp}$ & $\begin{array}{l}\text { Base load }+ \text { hp } \\
\text { Line to Line motor start } \\
\text { Four motor combination }\end{array}$ & $\begin{array}{c}\text { Inductive } \\
\text { \& Resistive }\end{array}$ & 10 & 240 \\
\hline 25 & $150 \mathrm{~kW}$ & Base load & Resistive & 10 & 250 \\
\hline 26 & $150 \mathrm{~kW}$ & $\begin{array}{l}\text { Base load }+\mathrm{hp} \\
\text { Line to Line motor starts } \\
\text { Three motor combination }\end{array}$ & & 10 & 260 \\
\hline 27 & $150 \mathrm{~kW}$ & Base load & Resistive & 10 & 270 \\
\hline 28 & $25 \mathrm{hp}$ & $\begin{array}{l}\text { Base load }+\mathrm{hp} \\
\text { Line to Line motor starts } \\
\text { Three motor combination }\end{array}$ & $\begin{array}{l}\text { Inductive } \\
\text { \& Resistive }\end{array}$ & 10 & 280 \\
\hline
\end{tabular}




\begin{tabular}{|c|c|c|c|c|c|}
\hline \multicolumn{7}{|c|}{ Base Load - 150 kW } \\
\hline Steps & Load Step & Comments & Load Type & $\begin{array}{c}\text { Duration } \\
\text { (seconds) }\end{array}$ & $\begin{array}{c}\text { Total Test Time } \\
\text { (seconds) }\end{array}$ \\
\hline 29 & $150 \mathrm{~kW}$ & Base load & Resistive & 10 & 290 \\
\hline 30 & $30 \mathrm{hp}$ & $\begin{array}{c}\text { Base load + hp } \\
\text { Line to Line motor starts } \\
\text { Four motor combination }\end{array}$ & $\begin{array}{c}\text { Inductive } \\
\text { \& Resistive }\end{array}$ & 10 & 300 \\
\hline 31 & $150 \mathrm{~kW}$ & Base load & Resistive & 10 & 310 \\
\hline
\end{tabular}

Table F9. BT005A test/table 5 as tested format.

\begin{tabular}{|c|c|c|c|c|c|}
\hline \multicolumn{6}{|c|}{ Base Load - $170 \mathrm{~kW}$} \\
\hline Steps & Load Step & Comments & Load Type & $\begin{array}{c}\text { Duration } \\
\text { (seconds) }\end{array}$ & $\begin{array}{c}\text { Total Test Time } \\
\text { (seconds) }\end{array}$ \\
\hline 1 & 100 & Base Load & Resistive & 2 & 10 \\
\hline 2 & $170 \mathrm{~kW}$ & Base load & Resistive & 10 & 20 \\
\hline 3 & $30 \mathrm{kV}$ & $200 \mathrm{~kW}$ total & Resistive & 10 & 30 \\
\hline 4 & $170 \mathrm{~kW}$ & Base load & Resistive & 10 & 40 \\
\hline 5 & $5 \mathrm{~h}$ & $\begin{array}{c}\text { Base load }+ \text { hp } \\
\text { Line to Line motor start }\end{array}$ & $\begin{array}{l}\text { Inductive } \\
\text { \& Resistive }\end{array}$ & 10 & 50 \\
\hline 6 & $170 \mathrm{~kW}$ & Base load & Resistive & 10 & 60 \\
\hline 7 & $10 \mathrm{hp}$ & $\begin{array}{l}\text { Base load }+\mathrm{hp} \\
\text { Line to Line motor starts } \\
\text { Two motor combination }\end{array}$ & $\begin{array}{l}\text { Inductive } \\
\text { \& Resistive }\end{array}$ & 10 & 70 \\
\hline 8 & $170 \mathrm{~kW}$ & Base load & Resistive & 10 & 80 \\
\hline 9 & $15 \mathrm{hp}$ & $\begin{array}{c}\text { Base load + hp } \\
\text { Line to Line motor start }\end{array}$ & $\begin{array}{l}\text { Inductive } \\
\text { \& Resistive }\end{array}$ & 10 & 90 \\
\hline 10 & $20 \mathrm{hp}$ & $\begin{array}{c}\text { Base load + hp } \\
\text { Soft Start motor start }\end{array}$ & $\begin{array}{l}\text { Inductive } \\
\text { \& Resistive }\end{array}$ & 10 & 100 \\
\hline 11 & $170 \mathrm{~kW}$ & Base load & Resistive & 10 & 110 \\
\hline 12 & $20 \mathrm{hp}$ & $\begin{array}{c}\text { Base load + hp } \\
\text { Line to Line motor start }\end{array}$ & $\begin{array}{l}\text { Inductive } \\
\text { \& Resistive }\end{array}$ & 10 & 120 \\
\hline 13 & $170 \mathrm{~kW}$ & Base load & Resistive & 10 & 130 \\
\hline 14 & $25 \mathrm{hp}$ & $\begin{array}{l}\text { Base load }+\mathrm{hp} \\
\text { Line to Line motor starts } \\
\text { Three motor combination }\end{array}$ & $\begin{array}{c}\text { Inductive } \\
\text { \& Resistive }\end{array}$ & 10 & 140 \\
\hline 15 & $170 \mathrm{~kW}$ & Base load & Resistive & 10 & 150 \\
\hline 16 & $30 \mathrm{hp}$ & $\begin{array}{l}\text { Base load }+\mathrm{hp} \\
\text { Line to Line motor starts } \\
\text { Four motor combination }\end{array}$ & $\begin{array}{l}\text { Inductive } \\
\text { \& Resistive }\end{array}$ & 10 & 160 \\
\hline 17 & $170 \mathrm{~kW}$ & Base load & Resistive & 10 & 170 \\
\hline End & & & & & \\
\hline
\end{tabular}




\section{Appendix G: BT005B Test Plan}

\section{Outline}

Two overload test formats will be performed on the fuel cell power plant (FCPP). The first test format will consist of applying a overload step for 1,2,3, and 4 second duration's to a base load of $200 \mathrm{~kW}$. The cumulative resistive load steps will to be applied to the FCPP output until either an overload condition is reached (FCPP goes to idle or shutdown) or all steps are successfully applied. Data will be captured at high speed for each step load at selected test duration's. It is anticipated that the FCPP will either transfer to idle or shutdown when an overload condition is met. This test will end when either of the following event happenings: shutdown or idle condition or all steps are applied with no mishaps.

The second test format will consist of starting with the highest power level from the previous overload test that was able to operate for the maximum 4 second duration. This overload condition will be tested to see if a steady state continuous power condition is reached (10 second duration). The overload amount will be reduced at $5 \mathrm{~kW}$ steps if needed to obtain the overload steady state continuous operating condition of the FCPP.

\section{Daily Start Up / Pre-Test Review (No Heat Recovery)}

- Fuel Cell in Local Operation

- Manual Disconnect Switch (GI Load) Closed, MDS003

- Manual Disconnect Switch (GC Load) Closed, MDS001

- Grid Connected MCB Closed, MCB002

- Grid Independent MCB Closed, MCB001

- Cooling Module Operational

- Thermal Flow pump Off, PMP 410 \& VFD 413

- Low Grade Heat valves Closed, TLB 412

- High Grade Heat valves Closed, TLB 422 \& TLB 423

- Thermal Load Bank crossover valves Closed, TLB 420 \& TLB 421

- Chilled Water Supply Valve Closed, TLB 425

- Verify Nitrogen Injection Valve Closed, FPB 758 
- Verify Fuel Cell is operating on Natural Gas

- Verify Fuel Cell is at desired power level.

\section{Test Procedure - Test Format 1}

1.0 Verify Grid Independent loads off status.

2.0 Set up the desired Grid Independent test plan on CDAQ as outlined in test/table format 1of this test plan.

3.0 Configure CDAQ data recording at $1 / 2$ second update rate for the miscellaneous \& ELB data.

4.0 Set up portable high-speed data acquisition system to capture data at a sampling rate of $\mathbf{1 0 0 0}$ samples/second from the Resistive Load Bank (RLB) and Motor Load Bank (MLB).

5.0 Set up Dranetz 658 Disturbance Analyzer to record power quality data.

6.0 Connect PC to LDT port and select Grid Independent Load - disconnect.

7.0 Connect CTC's CDAQ (RADAR DAQ connection) cable to the LDT port.

8.0 Initiate Test via CDAQ - This sequence will begin the desired test as outlined in test/table format 1 . The following data acquisition will also be initiated at the start of each test.

8.1 UTC Fuel Cells RADAR data snapshot.

8.2 Miscellaneous \& ELB data acquisition (at $1 / 2$ second update)

8.3 High-speed data acquisition (at 1000 samples/second)

8.4 Dranetz 658 Disturbance Analyzer data recording

9.0 Perform desired test outlined in test/table format 1 . This process will be automatically controlled via CDAQ. The following data acquisition shutdown will occur at the end of each test.

9.1 UTC Fuel Cells RADAR data snapshot.

9.2 Miscellaneous \& ELB data acquisition

9.3 High-speed data acquisition

9.4 Dranetz 658 Disturbance Analyzer data recording

10.0 End BT005B test format 1 - reset power plant to the default operating condition.

\section{Test Procedure - Test Format 2}

1.0 Verify Grid Independent loads off status.

2.0 Configure CDAQ data recording at $1 / 2$ second update rate for the miscellaneous \& ELB data.

3.0 Set up portable high-speed data acquisition system to capture data at a sampling rate of 1000 samples/second from the Resistive Load Bank (RLB) and Motor Load Bank (MLB).

4.0 Set up Dranetz 658 Disturbance Analyzer to record power quality data.

5.0 Set up the desired step load outlined in test/table format 2 on CDAQ. Desired step load starting point determined from previous overload test. Test/table format 2 identifies all possible step loads from test format 1.

6.0 Connect PC to LDT port and select Grid Independent Load - disconnect. 
7.0 Connect $C T C^{\circ}$ s CDAQ (RADAR DAQ connection) cable to the LDT port.

8.0 Initiate Test via CDAQ - This sequence will apply the desired load to the FCPP for 10 -second duration.

9.0 Go to step 5.0 and repeat with next lower step load if a ten second continuous operation was not met. Repeat steps 5.0 to 9.0 until a continuous operation condition was met for a applied load.

10.0 Set-up CDAQ with the load step that was able to operate continuously for ten-seconds.

11.0 Initiate test via CDAQ - The following data acquisition will parameters will be acquired during this test.

11.1 UTC Fuel Cells RADAR data snapshot.

11.2 Miscellaneous \& ELB data acquisition (at $1 / 2$ second update)

11.3 High-speed data acquisition (at 1000 samples/second)

11.4 Dranetz 658 Disturbance Analyzer data recording

12.0 Perform desired test. The following data acquisition shutdown will occur at the end of this test.

12.1 UTC Fuel Cells RADAR data snapshot.

12.2 Miscellaneous \& ELB data acquisition

12.3 High-speed data acquisition

12.4 Dranetz 658 Disturbance Analyzer data recording

13.0 End BT005B test format 2 - reset power plant to the default operating condition.

\section{Data Acquisition Parameters}

Table G1. BT005B test, miscellaneous data acquisition parameters.

\begin{tabular}{|c|c|c|}
\hline Fluid Flow Temperature In & Cross pressure & AP401 \\
\hline Fluid Flow Temperature Out & $\begin{array}{c}\text { Inside Ambient Air Tem- } \\
\text { perature }\end{array}$ & AP402 \\
\hline Outside Ambient Air Temperature & Discharge Air Temperature & AP403 \\
\hline & & AP404 \\
\hline & & AP405 \\
\hline & & PT3000 \\
\hline & & PT3001 \\
\hline
\end{tabular}


Table G2. BT005B test, ELB data acquisition parameters status.

\begin{tabular}{|c|c|c|c|}
\hline 20 hp PWM Line Side & 50 hp SS Line Side & 50 kW Resistor - A & Fan $4-5 \mathrm{hp}$ \\
\hline 20 hp PWM Load Side & 50 hp SS Load Side & 50 kW Resistor - B & Pump - $15 \mathrm{hp}$ \\
\hline 20 hp SS Line Side & 50 hp SS Enabler & 50 kW Resistor - C & \\
\hline 20 hp SS Load Side & 5 kW Resistor & 50 kW Resistor - D & \\
\hline 20 hp SS Enabler & 10 kW Resistor & Fan $1-5 \mathrm{hp}$ & \\
\hline $20 \mathrm{hp}$ SS Starter & 20 kW Resistor - A & Fan $2-5 \mathrm{hp}$ & \\
\hline 50 hp SS Starter & 20 kW Resistor - B & Fan $3-5 \mathrm{hp}$ & \\
\hline
\end{tabular}

Table G3. BT005B test, ELB data acquisition parameters values

\begin{tabular}{|l|l|l|}
\hline L1-N Voltage & L2-N Voltage & L3-N Voltage \\
\hline RLB L1 Current & RLB L2 Current & RLB L3 Current \\
\hline MLB KWattmeter & & \\
\hline
\end{tabular}

Table G4. BT005B test, high speed data acquisition parameters.

\begin{tabular}{|l|l|l|}
\hline MLB Phase 1 - Instant. Amps & RLB Phase 1 - RMS Amps & Phase 3 - L/N Instant. Volts \\
\hline MLB Phase 2 - Instant. Amps & RLB Phase 2 - RMS Amps & Phase 1 - L/N RMS Volts \\
\hline MLB Phase 3 - Instant. Amps & RLB Phase 3 - RMS Amps & Phase 2 - L/N RMS Volts \\
\hline MLB kW & Phase 1 - L/N Instant. Volts & Phase 3 - L/N RMS Volts \\
\hline Stack - DC Instant. Volts & Phase 2 - L/N Instant. Volts & \\
\hline
\end{tabular}

Table G5. BT005B test table format 1.

\begin{tabular}{|c|c|c|c|c|c|}
\hline \multicolumn{6}{|c|}{ Base Load - $200 \mathrm{~kW}$} \\
\hline Steps & Load Step & Comments & Load Type & $\begin{array}{c}\text { Duration } \\
\text { (seconds) }\end{array}$ & $\begin{array}{c}\text { Total Test Time } \\
\text { (seconds) }\end{array}$ \\
\hline 1 & 200 kW & Base load & Resistive & 5 & 5 \\
\hline 2 & $10 \mathrm{~kW}$ & $210 \mathrm{~kW}$ total & Resistive & 1 & 6 \\
\hline 3 & $200 \mathrm{~kW}$ & Base load & Resistive & 5 & 11 \\
\hline 4 & $10 \mathrm{~kW}$ & $210 \mathrm{~kW}$ total & Resistive & 2 & 13 \\
\hline 5 & $200 \mathrm{~kW}$ & Base load & Resistive & 5 & 18 \\
\hline 6 & $10 \mathrm{~kW}$ & $210 \mathrm{~kW}$ total & Resistive & 3 & 21 \\
\hline 7 & $200 \mathrm{~kW}$ & Base load & Resistive & 5 & 26 \\
\hline 8 & $10 \mathrm{~kW}$ & $210 \mathrm{~kW}$ total & Resistive & 4 & 30 \\
\hline 9 & $200 \mathrm{~kW}$ & Base load & Resistive & 5 & 35 \\
\hline 10 & $20 \mathrm{~kW}$ & $220 \mathrm{~kW}$ total & Resistive & 1 & 36 \\
\hline 11 & $200 \mathrm{~kW}$ & Base load & Resistive & 5 & 41 \\
\hline 12 & $20 \mathrm{~kW}$ & $220 \mathrm{~kW}$ total & Resistive & 2 & 43 \\
\hline 13 & $200 \mathrm{~kW}$ & Base load & Resistive & 5 & 48 \\
\hline 14 & $20 \mathrm{~kW}$ & $220 \mathrm{~kW}$ total & Resistive & 3 & 51 \\
\hline 15 & $200 \mathrm{~kW}$ & Base load & Resistive & 5 & 56 \\
\hline 16 & $20 \mathrm{~kW}$ & $220 \mathrm{~kW}$ total & Resistive & 4 & 60 \\
\hline 17 & $200 \mathrm{~kW}$ & Base load & Resistive & 5 & 65 \\
\hline 18 & $30 \mathrm{~kW}$ & $230 \mathrm{~kW}$ total & Resistive & 1 & 66 \\
\hline
\end{tabular}




\begin{tabular}{|c|c|c|c|c|c|}
\hline \multicolumn{6}{|c|}{ Base Load - $200 \mathrm{~kW}$} \\
\hline Steps & Load Step & Comments & Load Type & $\begin{array}{c}\text { Duration } \\
\text { (seconds) }\end{array}$ & $\begin{array}{c}\text { Total Test Time } \\
\text { (seconds) }\end{array}$ \\
\hline 19 & 200 kW & Base load & Resistive & 5 & 71 \\
\hline 20 & $30 \mathrm{~kW}$ & $230 \mathrm{~kW}$ total & Resistive & 2 & 73 \\
\hline 21 & $200 \mathrm{~kW}$ & Base load & Resistive & 5 & 78 \\
\hline 22 & $30 \mathrm{~kW}$ & $230 \mathrm{~kW}$ total & Resistive & 3 & 81 \\
\hline 23 & $200 \mathrm{~kW}$ & Base load & Resistive & 5 & 86 \\
\hline 24 & $30 \mathrm{~kW}$ & $230 \mathrm{~kW}$ total & Resistive & 4 & 90 \\
\hline 25 & $200 \mathrm{~kW}$ & Base load & Resistive & 5 & 95 \\
\hline 26 & $35 \mathrm{~kW}$ & $235 \mathrm{~kW}$ total & Resistive & 1 & 96 \\
\hline 27 & $200 \mathrm{~kW}$ & Base load & Resistive & 5 & 101 \\
\hline 28 & $35 \mathrm{~kW}$ & $235 \mathrm{~kW}$ total & Resistive & 2 & 103 \\
\hline 29 & $200 \mathrm{~kW}$ & Base load & Resistive & 5 & 108 \\
\hline 30 & $35 \mathrm{~kW}$ & $235 \mathrm{~kW}$ total & Resistive & 3 & 111 \\
\hline 31 & $200 \mathrm{~kW}$ & Base load & Resistive & 5 & 116 \\
\hline 32 & $35 \mathrm{~kW}$ & $235 \mathrm{~kW}$ total & Resistive & 4 & 120 \\
\hline 33 & $200 \mathrm{~kW}$ & Base load & Resistive & 5 & 125 \\
\hline \multicolumn{6}{|c|}{ Base Load - 200 kW } \\
\hline Steps & Load Step & Comments & Load Type & $\begin{array}{l}\text { Duration } \\
\text { (seconds) }\end{array}$ & $\begin{array}{l}\text { Total Test Time } \\
\text { (seconds) }\end{array}$ \\
\hline 34 & $40 \mathrm{~kW}$ & $240 \mathrm{~kW}$ total & Resistive & 1 & 126 \\
\hline 35 & $200 \mathrm{~kW}$ & Base load & Resistive & 5 & 131 \\
\hline 36 & $40 \mathrm{~kW}$ & $240 \mathrm{~kW}$ total & Resistive & 2 & 133 \\
\hline 37 & $200 \mathrm{~kW}$ & Base load & Resistive & 5 & 138 \\
\hline 38 & $40 \mathrm{~kW}$ & $240 \mathrm{~kW}$ total & Resistive & 3 & 141 \\
\hline 39 & $200 \mathrm{~kW}$ & Base load & Resistive & 5 & 146 \\
\hline 40 & $40 \mathrm{~kW}$ & $240 \mathrm{~kW}$ total & Resistive & 4 & 150 \\
\hline 41 & $200 \mathrm{~kW}$ & Base load & Resistive & 5 & 155 \\
\hline 42 & $45 \mathrm{~kW}$ & $245 \mathrm{~kW}$ total & Resistive & 1 & 156 \\
\hline 43 & $200 \mathrm{~kW}$ & Base load & Resistive & 5 & 161 \\
\hline 44 & $45 \mathrm{~kW}$ & $245 \mathrm{~kW}$ total & Resistive & 2 & 163 \\
\hline 45 & $200 \mathrm{~kW}$ & Base load & Resistive & 5 & 168 \\
\hline 46 & $45 \mathrm{~kW}$ & $245 \mathrm{~kW}$ total & Resistive & 3 & 171 \\
\hline 47 & $200 \mathrm{~kW}$ & Base load & Resistive & 5 & 176 \\
\hline 48 & $45 \mathrm{~kW}$ & $245 \mathrm{~kW}$ total & Resistive & 4 & 180 \\
\hline 49 & $200 \mathrm{~kW}$ & Base load & Resistive & 5 & 185 \\
\hline 50 & $50 \mathrm{~kW}$ & $250 \mathrm{~kW}$ total & Resistive & 1 & 186 \\
\hline 51 & $200 \mathrm{~kW}$ & Base load & Resistive & 5 & 191 \\
\hline 52 & $50 \mathrm{~kW}$ & $250 \mathrm{~kW}$ total & Resistive & 2 & 193 \\
\hline 53 & $200 \mathrm{~kW}$ & Base load & Resistive & 5 & 198 \\
\hline 54 & $50 \mathrm{~kW}$ & $250 \mathrm{~kW}$ total & Resistive & 3 & 201 \\
\hline
\end{tabular}




\begin{tabular}{|c|c|c|c|c|c|}
\hline \multicolumn{7}{|c|}{} & Base Load - 200 kW \\
\hline Steps & Load Step & Comments & Load Type & $\begin{array}{c}\text { Duration } \\
\text { (seconds) }\end{array}$ & $\begin{array}{c}\text { Total Test Time } \\
\text { (seconds) }\end{array}$ \\
\hline 55 & $200 \mathrm{~kW}$ & Base load & Resistive & 5 & 206 \\
\hline 56 & $50 \mathrm{~kW}$ & $250 \mathrm{~kW}$ total & Resistive & 4 & 210 \\
\hline 57 & $200 \mathrm{~kW}$ & Base load & Resistive & 5 & 215 \\
\hline End & \multicolumn{7}{|l}{} \\
\hline
\end{tabular}

Table G6. BT005B test, table format $2 A$.

\begin{tabular}{|c|c|c|c|c|}
\hline Steps & Load Step & $\begin{array}{l}\text { Continuous Operation } \\
\text { (>10 second duration) }\end{array}$ & Load Type & $\begin{array}{l}\text { Duration } \\
\text { (seconds) }\end{array}$ \\
\hline 1 & $250 \mathrm{~kW}$ & $\begin{array}{c}\text { Yes }- \text { test done } \\
\text { No - procedure to next step }\end{array}$ & Resistive & 10 \\
\hline 2 & $245 \mathrm{~kW}$ & $\begin{array}{c}\text { Yes - test done } \\
\text { No - procedure to next step }\end{array}$ & Resistive & 10 \\
\hline 3 & $240 \mathrm{~kW}$ & $\begin{array}{c}\text { Yes - test done } \\
\text { No - procedure to next step }\end{array}$ & Resistive & 10 \\
\hline 4 & $235 \mathrm{~kW}$ & $\begin{array}{c}\text { Yes }- \text { test done } \\
\text { No - procedure to next step }\end{array}$ & Resistive & 10 \\
\hline 5 & $230 \mathrm{~kW}$ & $\begin{array}{c}\text { Yes }- \text { test done } \\
\text { No - procedure to next step }\end{array}$ & Resistive & 10 \\
\hline 6 & $225 \mathrm{~kW}$ & $\begin{array}{c}\text { Yes }- \text { test done } \\
\text { No - procedure to next step }\end{array}$ & Resistive & 10 \\
\hline 7 & $220 \mathrm{~kW}$ & $\begin{array}{c}\text { Yes }- \text { test done } \\
\text { No - procedure to next step }\end{array}$ & Resistive & 10 \\
\hline 8 & $215 \mathrm{~kW}$ & $\begin{array}{c}\text { Yes }- \text { test done } \\
\text { No - procedure to next step }\end{array}$ & Resistive & 10 \\
\hline 9 & $210 \mathrm{~kW}$ & $\begin{array}{c}\text { Yes }- \text { test done } \\
\text { No - procedure to next step }\end{array}$ & Resistive & 10 \\
\hline \multicolumn{5}{|l|}{ End } \\
\hline
\end{tabular}

Table G7. BT005B test, table format 2B.

\begin{tabular}{|l|l|l|l|c|c|}
\hline Steps & \multicolumn{1}{|c|}{ Load Step } & \multicolumn{1}{c|}{ Comments } & \multicolumn{1}{c|}{ Load Type } & $\begin{array}{c}\text { Duration } \\
\text { (seconds) }\end{array}$ & $\begin{array}{c}\text { Total Test Time } \\
\text { (seconds) }\end{array}$ \\
\hline 1 & $100 \mathrm{~kW}$ & Increase load & Resistive & 2 & 2 \\
\hline 2 & $150 \mathrm{~kW}$ & Increase load & Resistive & 5 & 7 \\
\hline 3 & $200 \mathrm{~kW}$ & Increase load & Resistive & 5 & 12 \\
\hline 4 & $220 \mathrm{~kW}$ & Base load & Resistive & 10 & 22 \\
\hline 5 & $200 \mathrm{~kW}$ & Reduced load & Resistive & 10 & 32 \\
\hline 6 & $220 \mathrm{~kW}$ & Base load & Resistive & 10 & 42 \\
\hline 7 & $200 \mathrm{~kW}$ & Reduced load & Resistive & 5 & 47 \\
\hline 8 & 0 & Removed load & & 2 & 49 \\
\hline
\end{tabular}




\section{Appendix H: BT005D Test Plan}

\section{Outline}

The Power Quality Test will be performed on the fuel cell power plant (FCPP) to indicate the relative quantity of supplied power from the fuel cell while serving non-linear loads. The FCPP will be configured for grid independent mode. An applied resistive or resistive \& inductive load will be connected to the FCPP electrical output. Data will be captured for each test at high speed. Each test will end when either of the following event happenings: shutdown or idle condition or test completed with no mishaps. A total of nine (9) tests are anticipated to be completed. Three (3) main tests each with three (3) sub tests.

\section{Daily Start Up / Pre-Test Review (No Heat Recovery)}

- Fuel Cell in Local Operation

- Manual Disconnect Switch (GI Load) Closed, MDS003

- Manual Disconnect Switch (GC Load) Closed, MDS001

- Grid Connected MCB Closed MCB002

- Grid Independent MCB Closed, MCB001

- Cooling Module Operational

- Thermal Flow pump Off, PMP 410 \& VFD 413

- Low Grade Heat valves Closed, TLB 412

- High Grade Heat valves Closed, TLB 422 \& TLB 423

- Thermal Load Bank crossover valves Closed, TLB 420 \& TLB 421

- Chilled Water Supply Valve Closed, TLB 425

- Verify Nitrogen Injection Valve Closed, FPB 758

- Verify Fuel Cell is operating on Natural Gas

- Verify Fuel Cell is at desired power level.

\section{Test Procedure}

1.0 Verify Grid Independent loads off status. 
2.0 With the LDT computer installed switch the power plant over to grid independent mode.

3.0 Replace the LDT cable with the DAQ cable for sampling.

4.0 Set up the test plan on CDAQ in accordance with the applied loads identified in the tables.

5.0 Set up portable high-speed data acquisition system to capture data at a sampling rate of $\mathbf{1 0 0 0}$ samples/second from the Resistive Load Bank (RLB) \& motor load bank (MLB).

6.0 Set up Dranetz 658 Disturbance Analyzer to record power quality data.

7.0 Capture a RADAR snapshot of all steady-state values and set points.

8.0 Start high-speed data acquisition.

9.0 Start Dranetz 658 Disturbance Analyzer data recording.

10.0 Initiate Test via CDAQ - This sequence will begin the desired test line number as outlined in the Test Tables. The following data acquisition parameters will be acquired during this test.

10.0 UTC Fuel Cells RADAR data snapshot.

10.1 Miscellaneous \& ELB data acquisition (at $1 / 2$ second update)

10.2 High-speed data acquisition (at 1000 samples/second)

10.3 Dranetz 658 Disturbance Analyzer data recording

11.0 Perform the following data acquisition shutdown

11.0 UTC Fuel Cells RADAR data snapshot.

11.1 Miscellaneous \& ELB data acquisition

11.2 High-speed data acquisition

11.3 Dranetz 658 Disturbance Analyzer data recording

12.0 Repeat for each table sequence.

13.0 End BT005D test - reset power plant to the default operating condition.

\section{Data Acquisition Parameters}

Table H1. BT005D test, miscellaneous data acquisition parameters.

\begin{tabular}{|c|c|c|}
\hline $\begin{array}{l}\text { Cooling Module Information } \\
\text { From CTC Sensors }\end{array}$ & $\begin{array}{l}\text { Thermal Management } \\
\text { System Parameters }\end{array}$ & $\begin{array}{l}\text { Cell Stack Assembly (CSA) } \\
\text { cross pressure from sensors. }\end{array}$ \\
\hline Fluid Flow Temperature In & AP401 & PT3000 \\
\hline Fluid Flow Temperature Out & AP402 & РT3001 \\
\hline Outside Ambient Air Temperature & AP403 & \\
\hline Inside Ambient Air Temperature & AP404 & \\
\hline Discharge Air Temperature & AP405 & \\
\hline
\end{tabular}

Table H2. BT005D test, high speed data acquisition parameters.

\begin{tabular}{|l|l|l|}
\hline MLB Phase 1 - Instant. Amps & RLB Phase 1 - RMS Amps & Phase 3 - L/N Instant. Volts \\
\hline MLB Phase 2 - Instant. Amps & RLB Phase 2 - RMS Amps & Phase 1 - L/N RMS Volts \\
\hline MLB Phase 3 - Instant. Amps & RLB Phase 3 - RMS Amps & Phase 2 - L/N RMS Volts \\
\hline MLB kW & Phase 1 - L/N Instant. Volts & Phase 3 - L/N RMS Volts \\
\hline Stack - DC Instant. Volts & Phase 2 - L/N Instant. Volts & \\
\hline
\end{tabular}


Table H3. BT005D test, ELB data acquisition parameters status.

\begin{tabular}{|c|c|c|c|}
\hline $\begin{array}{l}20 \text { hp PWM Line } \\
\text { Side }\end{array}$ & $\begin{array}{l}50 \text { hp SS Line } \\
\text { Side }\end{array}$ & $\begin{array}{l}50 \mathrm{~kW} \text { Resistor - } \\
\text { A }\end{array}$ & Fan $4-5$ hp \\
\hline $\begin{array}{l}20 \text { hp PWM Load } \\
\text { Side }\end{array}$ & $\begin{array}{l}50 \text { hp SS Load } \\
\text { Side }\end{array}$ & 50 kW Resistor - B & Pump - 15 hp \\
\hline 20 hp SS Line Side & $50 \mathrm{hp}$ SS Enabler & $\begin{array}{l}50 \mathrm{~kW} \text { Resistor - } \\
\mathrm{C}\end{array}$ & \\
\hline 20 hp SS Load Side & 5 kW Resistor & $\begin{array}{l}50 \mathrm{~kW} \text { Resistor - } \\
\text { D }\end{array}$ & \\
\hline $20 \mathrm{hp}$ SS Enabler & 10 kW Resistor & Fan $1-5 \mathrm{hp}$ & \\
\hline 20 hp SS Starter & 20 kW Resistor - A & Fan $2-5 \mathrm{hp}$ & \\
\hline 50 hp SS Starter & 20 kW Resistor - B & Fan $3-5$ hp & \\
\hline
\end{tabular}

Table H4. BT005D test, ELB data acquisition parameters values.

\begin{tabular}{|l|l|l|}
\hline L1-N Voltage & L2-N Voltage & L3-N Voltage \\
\hline RLB L1 Current & RLB L2 Current & RLB L3 Current \\
\hline MLB KWattmeter & & \\
\hline
\end{tabular}

\section{Test 1 Full Load Resistive}

Table H5. BT005D test 1, full load resistive, 100\% Speed.

\begin{tabular}{|c|c|c|c|c|c|}
\hline & Resistive Load kW & Nonlinear Load hp & Description & Duration & Total Test Time \\
\hline 0 & 0 & 0 & Start & 0 & 0 \\
\hline 2 & 50 & 0 & & 5 & 5 \\
\hline 3 & 100 & 20 & $100 \%$ speed & 10 & 20 \\
\hline 4 & 100 & 20 & $100 \%$ speed & 5 & 25 \\
\hline 5 & 120 & 20 & $100 \%$ speed & 5 & 30 \\
\hline 6 & 140 & 20 & $100 \%$ speed & 5 & 35 \\
\hline 7 & 160 & 20 & $100 \%$ speed & 5 & 40 \\
\hline 8 & 180 & 20 & $100 \%$ speed & 5 & 45 \\
\hline 9 & 160 & 20 & $100 \%$ speed & 5 & 50 \\
\hline 10 & 140 & 20 & $100 \%$ speed & 5 & 55 \\
\hline 11 & 100 & 0 & $100 \%$ speed & 5 & 60 \\
\hline 12 & 50 & 0 & 5 & 5 & 70 \\
\hline 13 & 100 & 0 & & 5 & 5 \\
\hline
\end{tabular}


Table H6. BT005D test 1, full load resistive, 50\% speed.

\begin{tabular}{|c|c|c|c|c|c|}
\hline & Resistive Load kW & Nonlinear Load hp & Description & Duration & Total Test Time \\
\hline 0 & 0 & 0 & Start & 0 & 0 \\
\hline 1 & 50 & 0 & & 5 & 5 \\
\hline 2 & 100 & 0 & & 5 & 10 \\
\hline 3 & 100 & 20 & $50 \%$ speed & 10 & 20 \\
\hline 4 & 120 & 20 & $50 \%$ speed & 5 & 25 \\
\hline 5 & 140 & 20 & $50 \%$ speed & 5 & 30 \\
\hline 6 & 160 & 20 & $50 \%$ speed & 5 & 35 \\
\hline 7 & 180 & 20 & $50 \%$ speed & 5 & 40 \\
\hline 8 & 160 & 20 & $50 \%$ speed & 5 & 45 \\
\hline 9 & 140 & 20 & $50 \%$ speed & 5 & 50 \\
\hline 10 & 120 & 20 & $50 \%$ speed & 5 & 55 \\
\hline 11 & 100 & 20 & $50 \%$ speed & 5 & 60 \\
\hline 12 & 100 & 0 & & 5 & 65 \\
\hline
\end{tabular}

Table H7. BT005D test 1, full load resistive, $25 \%$ speed.

\begin{tabular}{|c|c|c|l|c|c|}
\hline & Resistive Load kW & Nonlinear Load hp & Description & Duration & Total Test Time \\
\hline 0 & 0 & 0 & Start & 0 & 0 \\
\hline 1 & 50 & 0 & & 5 & 5 \\
\hline 3 & 100 & 20 & $25 \%$ speed & 10 & 20 \\
\hline 4 & 120 & 20 & $25 \%$ speed & 5 & 25 \\
\hline 5 & 140 & 20 & $25 \%$ speed & 5 & 30 \\
\hline 6 & 160 & 20 & $25 \%$ speed & 5 & 35 \\
\hline 7 & 180 & 20 & $25 \%$ speed & 5 & 40 \\
\hline 8 & 160 & 20 & $25 \%$ speed & 5 & 45 \\
\hline 9 & 140 & 20 & $25 \%$ speed & 5 & 50 \\
\hline 10 & 120 & 20 & $25 \%$ speed & 5 & 55 \\
\hline 11 & 100 & 0 & $25 \%$ speed & 5 & 60 \\
\hline 12 & 100 & 50 & & 5 & 65 \\
\hline 13 & 100 & & 5 & 70 \\
\hline
\end{tabular}




\section{Test 2 Light Load Resistive}

Table H8. BT005D test 2, light load resistive, 100\% speed.

\begin{tabular}{|c|c|c|l|c|c|}
\hline & Resistive Load kW & Nonlinear Load hp & Description & Duration & Total Test Time \\
\hline 0 & 0 & 0 & Start & 0 & 0 \\
\hline 1 & 50 & 0 & $100 \%$ speed & 10 & 15 \\
\hline 2 & 50 & 20 & $100 \%$ speed & 5 & 20 \\
\hline 3 & 25 & 20 & $100 \%$ speed & 5 & 25 \\
\hline 4 & 10 & 20 & $100 \%$ speed & 5 & 30 \\
\hline 5 & 0 & 20 & & 5 & 35 \\
\hline 6 & 0 & 0 & & & 5 \\
\hline
\end{tabular}

Table H9. BT005D test 2, light load resistive, 50\% speed.

\begin{tabular}{|c|c|c|l|c|c|}
\hline & Resistive Load kW & Nonlinear Load hp & Description & Duration & Total Test Time \\
\hline 0 & 0 & 0 & Start & 0 & 0 \\
\hline 1 & 50 & 0 & $50 \%$ speed & 10 & 15 \\
\hline 2 & 50 & 200 & $50 \%$ speed & 5 & 20 \\
\hline 3 & 25 & 20 & $50 \%$ speed & 5 & 25 \\
\hline 4 & 10 & 20 & $50 \%$ speed & 5 & 30 \\
\hline 5 & 0 & 0 & & 5 & 35 \\
\hline 6 & 0 & 20 & & & 5 \\
\hline
\end{tabular}

Table H10. BT005D test 2, light load resistive, 25\% speed.

\begin{tabular}{|c|c|c|l|c|c|}
\hline & Resistive Load kW & Nonlinear Load hp & Description & Duration & Total Test Time \\
\hline 0 & 0 & 0 & Start & 0 & 0 \\
\hline 1 & 50 & 0 & $25 \%$ speed & 10 & 15 \\
\hline 2 & 50 & 20 & $25 \%$ speed & 5 & 20 \\
\hline 3 & 25 & 20 & $25 \%$ speed & 5 & 25 \\
\hline 4 & 10 & 20 & $25 \%$ speed & 5 & 30 \\
\hline 5 & 0 & 0 & & 5 & 35 \\
\hline
\end{tabular}




\section{Test 3 Motor and Resistive Loads}

Table H11. BT005D test 3, motor and resistive loads, $100 \%$ speed.

\begin{tabular}{|c|c|c|c|c|c|c|}
\hline & $\begin{array}{l}\text { Resistive } \\
\text { Load kW }\end{array}$ & Motor Load hp & $\begin{array}{c}\text { Nonlinear Load } \\
\text { hp }\end{array}$ & Description & Duration & $\begin{array}{c}\text { Total Test } \\
\text { Time }\end{array}$ \\
\hline 1 & 0 & 10 & 20 & $100 \%$ speed & 5 & 5 \\
\hline 2 & 0 & 20 & 20 & $100 \%$ speed & 5 & 10 \\
\hline 3 & 0 & 35 & 20 & $100 \%$ speed & 5 & 15 \\
\hline 4 & 50 & 35 & 20 & $100 \%$ speed & 5 & 20 \\
\hline 5 & 100 & 35 & 20 & $100 \%$ speed & 5 & 25 \\
\hline 6 & 145 & 35 & 20 & $100 \%$ speed & 5 & 30 \\
\hline 7 & 100 & 35 & 20 & $100 \%$ speed & 5 & 35 \\
\hline 8 & 50 & 35 & 20 & $100 \%$ speed & 5 & 40 \\
\hline 9 & 0 & 35 & 20 & $100 \%$ speed & 5 & 45 \\
\hline 10 & 0 & 20 & 20 & $100 \%$ speed & 5 & 50 \\
\hline 11 & 0 & 10 & 20 & $100 \%$ speed & 5 & 55 \\
\hline 12 & 0 & 0 & 0 & & 5 & 60 \\
\hline
\end{tabular}

Table H12. BT005D test 3, motor and resistive loads, $50 \%$ speed.

\begin{tabular}{|c|c|c|c|c|c|c|}
\hline & $\begin{array}{l}\text { Resistive } \\
\text { Load kW }\end{array}$ & $\begin{array}{c}\text { Motor Load } \\
\text { hp }\end{array}$ & $\begin{array}{c}\text { Nonlinear } \\
\text { Load hp }\end{array}$ & Description & Duration & $\begin{array}{c}\text { Total Test } \\
\text { Time }\end{array}$ \\
\hline 1 & 0 & 10 & 20 & $50 \%$ speed & 5 & 5 \\
\hline 2 & 0 & 20 & 20 & $50 \%$ speed & 5 & 10 \\
\hline 3 & 0 & 35 & 20 & $50 \%$ speed & 5 & 15 \\
\hline 4 & 50 & 35 & 20 & $50 \%$ speed & 5 & 20 \\
\hline 5 & 100 & 35 & 20 & $50 \%$ speed & 5 & 25 \\
\hline 6 & 145 & 35 & 20 & $50 \%$ speed & 5 & 30 \\
\hline 7 & 100 & 35 & 20 & $50 \%$ speed & 5 & 35 \\
\hline 8 & 50 & 35 & 20 & $50 \%$ speed & 5 & 40 \\
\hline 9 & 0 & 35 & 20 & $50 \%$ speed & 5 & 45 \\
\hline 10 & 0 & 20 & 20 & $50 \%$ speed & 5 & 50 \\
\hline 11 & 0 & 10 & 20 & $50 \%$ speed & 5 & 55 \\
\hline 12 & 0 & 0 & 0 & & 5 & 60 \\
\hline
\end{tabular}

Table H13. BT005D test 3, motor and resistive loads, $25 \%$ speed.

\begin{tabular}{|c|c|c|c|c|c|c|}
\hline & $\begin{array}{c}\text { Resistive } \\
\text { Load kW }\end{array}$ & $\begin{array}{c}\text { Motor Load } \\
\mathrm{hp}\end{array}$ & $\begin{array}{c}\text { Nonlinear } \\
\text { Load } \mathrm{hp}\end{array}$ & Description & Duration & $\begin{array}{c}\text { Total Test } \\
\text { Time }\end{array}$ \\
\hline
\end{tabular}




\begin{tabular}{|c|c|c|c|c|c|c|}
\hline 1 & 0 & 10 & 20 & $25 \%$ speed & 5 & 5 \\
\hline 2 & 0 & 20 & 20 & $25 \%$ speed & 5 & 10 \\
\hline 3 & 0 & 35 & 20 & $25 \%$ speed & 5 & 15 \\
\hline 4 & 50 & 35 & 20 & $25 \%$ speed & 5 & 20 \\
\hline 5 & 100 & 35 & 20 & $25 \%$ speed & 5 & 25 \\
\hline 6 & 145 & 35 & 20 & $25 \%$ speed & 5 & 30 \\
\hline 7 & 100 & 35 & 20 & $25 \%$ speed & 5 & 45 \\
\hline 8 & 50 & 35 & 20 & $25 \%$ speed & 5 & 45 \\
\hline 9 & 0 & 20 & 20 & $25 \%$ speed & 5 & 50 \\
\hline 10 & 0 & 10 & 20 & $25 \%$ speed & 5 & 55 \\
\hline 11 & 0 & 0 & 0 & & 5 & 60 \\
\hline 12 & 0 & & & & & 5 \\
\hline
\end{tabular}

\section{Transient Test, Motor Startup}

Table H14. BT005D transient test, motor startup, $50 \mathrm{hp}$ motor across the line start.

\begin{tabular}{|c|c|c|c|c|c|c|}
\hline & $\begin{array}{l}\text { Resistive } \\
\text { Load kW }\end{array}$ & $\begin{array}{c}\text { Motor Load } \\
\text { hp }\end{array}$ & $\begin{array}{c}\text { Nonlinear } \\
\text { Load hp }\end{array}$ & Description & Duration & $\begin{array}{c}\text { Total Test } \\
\text { Time }\end{array}$ \\
\hline 1 & 0 & 0 & 0 & & 3 & 3 \\
\hline 2 & 50 & 0 & 0 & & 5 & \\
\hline 3 & 100 & 0 & 0 & & 5 & \\
\hline 4 & 100 & 50 & 0 & Across Line & 10 & \\
\hline 5 & 100 & 0 & 0 & & 2 & \\
\hline 6 & 50 & 0 & 0 & & 2 & \\
\hline 7 & 0 & 0 & 0 & & 2 & \\
\hline 8 & OFF & & & & & \\
\hline & & & & & & \\
\hline
\end{tabular}


Table H15. BT005D transient test, motor startup, 20 hp motor ASD operation.

\begin{tabular}{|c|c|c|c|c|c|c|}
\hline & $\begin{array}{l}\text { Resistive } \\
\text { Load kW }\end{array}$ & $\begin{array}{l}\text { Motor Load } \\
\text { hp }\end{array}$ & $\begin{array}{l}\text { Nonlinear } \\
\text { Load hp }\end{array}$ & Description & Duration & $\begin{array}{l}\text { Total Test } \\
\text { Time }\end{array}$ \\
\hline 1 & 0 & 0 & 0 & & 3 & 3 \\
\hline 2 & 50 & 0 & 0 & & 5 & \\
\hline 3 & 100 & 0 & 0 & $25 \%$ Speed & 10 & 2 \\
\hline 4 & 100 & 0 & 20 & & 2 & \\
\hline 5 & 100 & 0 & 0 & & & \\
\hline 6 & 50 & 0 & 0 & & & \\
\hline 7 & 0 & 0 & 0 & & & \\
\hline 8 & OFF & & & & & \\
\hline
\end{tabular}




\section{Appendix I: BT008 Test Plan}

Title: Test Plan FCTP BT008A

Water Quality for SN9194

Test BT008A

\begin{tabular}{|l|l|l|l|}
\hline REV. LTR. & AUTHOR & RELEASE NO. & DATE \\
\hline- & LeAnne Debias & & 06 Nov 2001 \\
\hline & & & \\
\hline & & & \\
\hline & & & \\
\hline
\end{tabular}

PRODUCT FILE ADDRESS: Test Plan BT008A.DOC

\begin{tabular}{|l|l|l|l|}
\hline POWER PLANT/PROGRAM & SYSTEM \& TAG NO. & PART NO. & DOCUMENT NO. \\
\hline PC25C & & & FCTP BT008A \\
& & & PAGE 117 OF 5 \\
\hline
\end{tabular}

\begin{tabular}{|l|l|l|l|l|l|}
\hline & \multicolumn{2}{|l|}{ REVISION RECORD } & & & \\
\hline & & & & \\
\hline & & & & \\
\hline $\begin{array}{l}\text { DASH NO. } \\
\text { LTR }\end{array}$ & REL NO. & LTR & DESCRIPTION & DATE \\
\hline & & - & ORIGINAL ISSUE & 06 Nov 01 \\
\hline & & & & \\
\hline
\end{tabular}

\section{Objective}

Assess the water quality within the power plant cooling and water treatment system. 


\section{Length Of Test}

Collect samples for field analytical methods at a minimum interval of once each week and samples for laboratory analytical methods at a minimum interval of 4 weeks.

\section{Materials Required}

Water sample containers.

\section{Ports Location for the Samples}

- CTC Deionized make-up water

- (HV453)

- TMS Loop (HV431)

- Degasifier Column from the 4-in. PVC water return on the top of the water storage tank.

\section{Test Setup}

No special test set-up is required.

\section{Test Program}

1.0 Document the following information:

1.1 Date and time for each sample taken.

1.2 Determine whether a test is being performed and DAQ is running.

1.3 If DAQ is running, record the Test Name and capture a RADAR snapshot of all steady-state values and set points.

1.4 If DAQ is not running begin recording Fuel Cell RADAR Data using a sampling rate of 5 minutes and begin recording MISC Data at a sampling rate of 60 seconds, input a Test Name, and begin DAQ.

1.5 Record the hours of operation on the fuel cell, then determine the hours of operation since the last resin change-out, and record on LAB188 or LAB189.

2.0 Perform sampling at each of the following locations as required:

- CTC Deionized make-up water

- on board water storage tank from the hand valve located on the hose line feeding the charcoal bed

- Feed Water at the final mixed-bed deionizing tank (HV453)

- TMS Loop (HV431) 
- Degasifier Column from the 4-in. PVC water return on the top of the water storage tank (NOTE: perform this test only if results for previous locations indicate problems and UTC Fuel Cells request this location to be sampled).

3.0 Log information required on Lab Form LAB188, and analyze:

3.1 Collect a sample and analyze immediately for Dissolved Oxygen using Chem-et kits.

3.2 Collect an additional sample and analyze immediately for Conductivity.

3.3 Collect an additional sample and analyze immediately for $\mathrm{pH}$.

3.4 Collect 1 liter of sample in a plastic bottle and analyze for turbidity using Millipore filters and compare with Babcock and Wilcox Turbidity Charts.

3.5 If performing sampling for analysis using laboratory methods, log information on Lab Form LAB189, and analyze:

3.5.1 Collect a sample and analyze immediately for Dissolved Oxygen using the Yellow Springs Dissolved Oxygen Meter.

3.5.2 Collect an additional sample and analyze immediately for Conductivity.

3.5.3 Collect an additional sample and analyze immediately for $\mathrm{pH}$.

3.5.4 Collect a sample in a sterile sample bag and analyze for bacteria.

3.5.5 Collect 1 liter of sample in a plastic bottle and analyze for silica, Total Dissolved Solids, Total Suspended Solids, Total Organic Carbon, and turbidity (using the Nephelometer).

3.5.6 Analyze for ions (nitrate, nitrite, chloride, sulfate, and phosphate) using the Waters hpLC.

3.5.7 Analyze for metals (iron, copper, calcium, magnesium, and sodium) using the Varian Liberty 110 Inductively Coupled Plasma Optical Emission Spectrophotometer.

4.0 If a previous test was running, capture a RADAR snapshot of all steadystate values and set points, record Test Name, date and time. If DAQ was started for water sampling, collect a RADAR Snapshot and exit DAQ. 


\title{
Appendix J: Peak Load Shutdown Test
}

\author{
Test Plan For Residential Scale Fuel Cell Power Plants
}

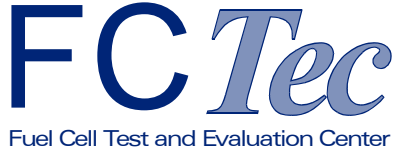

CTC Concurrent Technologies Corporation

Title: Peak Load Shutdown Test

\begin{tabular}{|l|l|l|l|}
\hline Revision Letter & Author & Release No. & Date \\
\hline P. 1 & Jeffrey D. Stangl & Preliminary & January 31, 2003 \\
\hline & & & \\
\hline & & & \\
\hline & & & \\
\hline
\end{tabular}

\begin{tabular}{|l|l|l|l|}
\hline \multicolumn{2}{|l|}{ Product File Address: TBD } \\
\hline $\begin{array}{l}\text { Power Plant Manu- } \\
\text { facturer }\end{array}$ & System Tag No. & $\begin{array}{l}\text { Technology of the } \\
\text { Fuel Cell Power Plant }\end{array}$ & Document No. \\
\hline TBD & TBD & TBD & TBD \\
\hline
\end{tabular}

\section{Objective}

The purpose of the Peak Load Shutdown Test is to determine the peak load supply power of the fuel cell being evaluated for both constant and changing electrical loads. The individual outputs of each fuel cell power plant to be evaluated may vary, and must be documented in the test notes. Primary evaluation shall concentrate on the fuel cell's ability to supply power without the complicating factors of large inductive transients and large impulse current. Initial testing shall consist of various levels of resistive loading. 
The peak load shutdown test shall determine the average peak load for three test operations. This value will be reduced by 5 percent to determine a starting load for the Sustained Load Test.

\section{Length of Test}

The length of the test is dependent on the peak load capabilities of the fuel cell power plant being evaluated. Example: Approximately 17 minutes will be required to test for a peak load of $5 \mathrm{~kW}$ (cf. Table J1).

\section{Material Required}

Propane, Hydrogen, or Natural Gas fuel.

\section{Test Setup}

- Follow the start up procedure in the operating instructions of the fuel cell power plant being evaluated

- Testing shall begin with the fuel cell in the off-line mode

- Prepare all data acquisition equipment for testing.

\section{Test Procedure}

1. Monitor the input of the fuel required by the fuel cell being tested. (Hydrogen, Natural Gas, etc.) Fuel cell output current (DC or AC), fuel cell output voltage (DC or AC), output load profile, air exhaust discharge rate, air exhaust discharge temperature, fuel cell stack temperature, and the ambient air temperature at the sampling rate as indicated in the data acquisition parameter table.

2. Start recording.

3. Turn on the fuel cell to be evaluated according to the manufacturer instructions.

4. Add resistive load segments in 50 watt sequences, remaining at each step for 10 seconds.

5. Continue increasing the load until the fuel cell system shuts down from overload.

6. Document the final load step.

7. Stop Recording

8. Restart the Fuel Cell being evaluated in the on - line mode according to the manufacturer instructions. 
9. Repeat the test three times.

10. Average the three (3) documented load values that the fuel cell shut down at to obtain the peak load.

11. End test.

\section{Data Acquisition Parameters}

Table J1. Peak load shutdown test, data acquisition parameters.

\begin{tabular}{|l|l|l|}
\hline $\begin{array}{l}\text { Electrical Information from } \\
\text { CTC Sensors. }\end{array}$ & $\begin{array}{l}\text { Fuel Supply Rate } \\
\text { from CTC Sensor }\end{array}$ & $\begin{array}{l}\text { Environmental Information } \\
\text { from CTC Sensors }\end{array}$ \\
\hline Sampling Rate 10 per second & Sampling Rate 10 per second & Sampling Rate 10 per second \\
\hline Gross Output, Stack Current & Inlet Fuel Mass Flow & Air Discharge Rate \\
\hline Net Output Current (AC or DC) & & Air Discharge Temperature \\
\hline Output Voltage (AC or DC) & & Ambient Air Temperature \\
\hline Output Load Profile & & Fuel Cell Stack Temperature \\
\hline
\end{tabular}

Table J2. Peak load shutdown test.

\begin{tabular}{|c|c|c|c|c|}
\hline Test \# & $\begin{array}{l}\text { Resistive } \\
\text { Loads Watts }\end{array}$ & $\begin{array}{l}\text { Duration } \\
\text { Seconds }\end{array}$ & $\begin{array}{l}\text { Total Test Time } \\
\text { Minutes/seconds }\end{array}$ & Comments \\
\hline 1 & 0 & 10 & $0: 10$ & \\
\hline 2 & 50 & 10 & $0: 20$ & \\
\hline 3 & 100 & 10 & $0: 30$ & \\
\hline 4 & 150 & 10 & $0: 40$ & \\
\hline 5 & 200 & 10 & $0: 50$ & \\
\hline 6 & 250 & 10 & $0: 60$ & \\
\hline 7 & 300 & 10 & $1: 10$ & \\
\hline 8 & 350 & 10 & $1: 20$ & \\
\hline 9 & 400 & 10 & $1: 30$ & \\
\hline 10 & 450 & 10 & $1: 40$ & \\
\hline 11 & 500 & 10 & $1: 50$ & \\
\hline 12 & 550 & 10 & $2: 00$ & \\
\hline 13 & 600 & 10 & $2: 10$ & \\
\hline 14 & 650 & 10 & $2: 20$ & \\
\hline 15 & 700 & 10 & $2: 30$ & \\
\hline 16 & 750 & 10 & $2: 40$ & \\
\hline 17 & 800 & 10 & $2: 50$ & \\
\hline 18 & 850 & 10 & 3:00 & \\
\hline 19 & 900 & 10 & $3: 10$ & \\
\hline 20 & 950 & 10 & $3: 20$ & \\
\hline 21 & 1000 & 10 & $3: 30$ & \\
\hline 22 & 1050 & 10 & $3: 40$ & \\
\hline 23 & 1100 & 10 & $3: 50$ & \\
\hline 24 & 1150 & 10 & $4: 00$ & \\
\hline
\end{tabular}




\begin{tabular}{|c|c|c|c|c|}
\hline Test \# & $\begin{array}{l}\text { Resistive } \\
\text { Loads Watts }\end{array}$ & $\begin{array}{l}\text { Duration } \\
\text { Seconds }\end{array}$ & $\begin{array}{l}\text { Total Test Time } \\
\text { Minutes/seconds }\end{array}$ & Comments \\
\hline 25 & 1200 & 10 & $4: 10$ & \\
\hline 26 & 1250 & 10 & $4: 20$ & \\
\hline 27 & 1300 & 10 & $4: 30$ & \\
\hline 28 & 1350 & 10 & $4: 40$ & \\
\hline 29 & 1400 & 10 & $4: 50$ & \\
\hline 30 & 1450 & 10 & $5: 00$ & \\
\hline 31 & 1500 & 10 & $5: 10$ & \\
\hline 32 & 1550 & 10 & $5: 20$ & \\
\hline 33 & 1600 & 10 & $5: 30$ & \\
\hline 34 & 1650 & 10 & $5: 40$ & \\
\hline 35 & 1700 & 10 & $5: 50$ & \\
\hline 36 & 1750 & 10 & $6: 00$ & \\
\hline 37 & 1800 & 10 & $6: 10$ & \\
\hline 38 & 1850 & 10 & $6: 20$ & \\
\hline 39 & 1900 & 10 & $6: 30$ & \\
\hline 40 & 1950 & 10 & $6: 40$ & \\
\hline 41 & 2000 & 10 & $6: 50$ & \\
\hline 42 & 2050 & 10 & $7: 00$ & \\
\hline 43 & 2100 & 10 & $7: 10$ & \\
\hline 44 & 2150 & 10 & $7: 20$ & \\
\hline 45 & 2200 & 10 & $7: 30$ & \\
\hline 46 & 2250 & 10 & $7: 40$ & \\
\hline 47 & 2300 & 10 & $7: 50$ & \\
\hline 48 & 2350 & 10 & $8: 00$ & \\
\hline 49 & 2400 & 10 & 8:10 & \\
\hline 50 & 2450 & 10 & $8: 20$ & \\
\hline 51 & 2500 & 10 & $8: 30$ & \\
\hline 52 & 2550 & 10 & $8: 40$ & \\
\hline 53 & 2600 & 10 & $8: 50$ & \\
\hline 54 & 2650 & 10 & $9: 00$ & \\
\hline 55 & 2700 & 10 & 9:10 & \\
\hline 56 & 2750 & 10 & $9: 20$ & \\
\hline 57 & 2800 & 10 & $9: 30$ & \\
\hline 58 & 2850 & 10 & $9: 40$ & \\
\hline 59 & 2900 & 10 & $9: 50$ & \\
\hline 60 & 2950 & 10 & $10: 00$ & \\
\hline 61 & 3000 & 10 & $10: 10$ & \\
\hline 62 & 3050 & 10 & $10: 20$ & \\
\hline 63 & 3100 & 10 & $10: 30$ & \\
\hline 64 & 3150 & 10 & $10: 40$ & \\
\hline 65 & 3200 & 10 & $10: 50$ & \\
\hline 66 & 3250 & 10 & $11: 00$ & \\
\hline
\end{tabular}




\begin{tabular}{|c|c|c|c|c|}
\hline Test \# & $\begin{array}{l}\text { Resistive } \\
\text { Loads Watts }\end{array}$ & $\begin{array}{l}\text { Duration } \\
\text { Seconds }\end{array}$ & $\begin{array}{l}\text { Total Test Time } \\
\text { Minutes/seconds }\end{array}$ & Comments \\
\hline 67 & 3300 & 10 & $11: 10$ & \\
\hline 68 & 3350 & 10 & $11: 20$ & \\
\hline 69 & 3400 & 10 & $11: 30$ & \\
\hline 70 & 3450 & 10 & $11: 40$ & \\
\hline 71 & 3500 & 10 & $11: 50$ & \\
\hline 72 & 3550 & 10 & $12: 00$ & \\
\hline 73 & 3600 & 10 & $12: 10$ & \\
\hline 74 & 3650 & 10 & $12: 20$ & \\
\hline 75 & 3700 & 10 & $12: 30$ & \\
\hline 76 & 3750 & 10 & $12: 40$ & \\
\hline 77 & 3800 & 10 & $12: 50$ & \\
\hline 78 & 3850 & 10 & 13:00 & \\
\hline 79 & 3900 & 10 & $13: 10$ & \\
\hline 80 & 3950 & 10 & $13: 20$ & \\
\hline 81 & 4000 & 10 & $13: 30$ & \\
\hline 82 & 4050 & 10 & $13: 40$ & \\
\hline 83 & 4100 & 10 & $13: 50$ & \\
\hline 84 & 4150 & 10 & $14: 00$ & \\
\hline 85 & 4200 & 10 & $14: 10$ & \\
\hline 86 & 4250 & 10 & $14: 20$ & \\
\hline 87 & 4300 & 10 & $14: 30$ & \\
\hline 88 & 4350 & 10 & $14: 40$ & \\
\hline 89 & 4400 & 10 & $14: 50$ & \\
\hline 90 & 4450 & 10 & $15: 00$ & \\
\hline 91 & 4500 & 10 & $15: 10$ & \\
\hline 92 & 4550 & 10 & $15: 20$ & \\
\hline 93 & 4600 & 10 & $15: 30$ & \\
\hline 94 & 4650 & 10 & $15: 40$ & \\
\hline 95 & 4700 & 10 & $15: 50$ & \\
\hline 96 & 4750 & 10 & $16: 00$ & \\
\hline 97 & 4800 & 10 & $16: 10$ & \\
\hline 98 & 4850 & 10 & $16: 20$ & \\
\hline 99 & 4900 & 10 & $16: 30$ & \\
\hline 100 & 4950 & 10 & $16: 40$ & \\
\hline 101 & 5000 & 10 & $16: 50$ & \\
\hline 102 & 5050 & 10 & $17: 00$ & \\
\hline 103 & 5100 & 10 & $17: 10$ & \\
\hline 104 & 5150 & 10 & $17: 20$ & \\
\hline 105 & 5200 & 10 & $17: 30$ & \\
\hline 106 & 5250 & 10 & $17: 40$ & \\
\hline 107 & 5300 & 10 & $17: 50$ & \\
\hline 108 & 5350 & 10 & 18:00 & \\
\hline
\end{tabular}




\begin{tabular}{|c|c|c|c|c|}
\hline Test \# & $\begin{array}{l}\text { Resistive } \\
\text { Loads Watts }\end{array}$ & $\begin{array}{l}\text { Duration } \\
\text { Seconds }\end{array}$ & $\begin{array}{l}\text { Total Test Time } \\
\text { Minutes/seconds }\end{array}$ & Comments \\
\hline 109 & 5400 & 10 & 18:10 & \\
\hline 110 & 5450 & 10 & $18: 20$ & \\
\hline 111 & 5500 & 10 & 18:30 & \\
\hline 112 & 5550 & 10 & $18: 40$ & \\
\hline 113 & 5600 & 10 & $18: 50$ & \\
\hline 114 & 5650 & 10 & 19:00 & \\
\hline 115 & 5700 & 10 & $19: 10$ & \\
\hline 116 & 5750 & 10 & $19: 20$ & \\
\hline 117 & 5800 & 10 & $19: 30$ & \\
\hline 118 & 5850 & 10 & $19: 40$ & \\
\hline 119 & 5900 & 10 & $19: 50$ & \\
\hline 120 & 5950 & 10 & 20:00 & \\
\hline 121 & 6000 & 10 & $20: 10$ & \\
\hline 122 & 6050 & 10 & $20: 20$ & \\
\hline 123 & 6100 & 10 & $20: 30$ & \\
\hline 124 & 6150 & 10 & $20: 40$ & \\
\hline 125 & 6200 & 10 & $20: 50$ & \\
\hline 126 & 6250 & 10 & $21: 00$ & \\
\hline 127 & 6300 & 10 & $21: 10$ & \\
\hline 128 & 6350 & 10 & $21: 20$ & \\
\hline 129 & 6400 & 10 & $21: 30$ & \\
\hline 130 & 6450 & 10 & $21: 40$ & \\
\hline 131 & 6500 & 10 & $21: 50$ & \\
\hline 132 & 6550 & 10 & 22:00 & \\
\hline 133 & 6600 & 10 & $22: 10$ & \\
\hline 134 & 6650 & 10 & $22: 20$ & \\
\hline 135 & 6700 & 10 & $22: 30$ & \\
\hline 136 & 6750 & 10 & $22: 40$ & \\
\hline 137 & 6800 & 10 & $22: 50$ & \\
\hline 138 & 6850 & 10 & 23:00 & \\
\hline 139 & 6900 & 10 & $23: 10$ & \\
\hline 140 & 6950 & 10 & $23: 20$ & \\
\hline 141 & 7000 & 10 & $23: 30$ & \\
\hline
\end{tabular}




\section{Appendix K: Sustained Load Test}

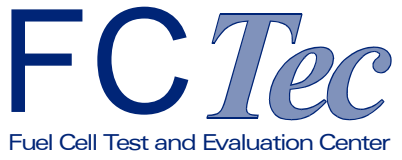

CTC

Concurrent Technologies Corporation

\section{Test Plan For Residential Scale Fuel Cell Power Plants}

Title: Sustained Load Test

\begin{tabular}{|l|l|l|l|}
\hline Revision Letter & Author & Release No. & Date \\
\hline P. 1 & Jeffrey D. Stangl & Preliminary & January 31, 2003 \\
\hline & & & \\
\hline & & & \\
\hline & & & \\
\hline
\end{tabular}

\begin{tabular}{|l|l|l|l|}
\hline \multicolumn{2}{|l|}{ Product File Address: TBD } \\
\hline Power Plant Manufacturer & System Tag No. & Technology of the Fuel Cell Power Plant & Document No. \\
\hline TBD & TBD & TBD & TBD \\
\hline
\end{tabular}

\section{Objective}

The purpose of the Sustained Load Test is to determine the maximum sustained load capable of the fuel cell being evaluated for both constant and changing electrical loads. The individual outputs of each fuel cell power plant to be evaluated may vary, and must be documented in the test notes. Primary evaluation shall concentrate on the fuel cell's ability to supply power without the complicating factors of large inductive transients and large impulse current. Initial testing shall consist of various levels of resistive loading. 


\section{Length of Test}

The length of this test for a given fuel cell power plant will be determined by the peak load shutdown value determined during the peak load shutdown test. Five (5) second load intervals will be used to reach the calculated sustained load. A 60 minute test will be completed at the calculated sustained load.

Note: If the fuel cell power plant fails at any time during the sustained load, the load will have to be reduced as is indicated in the test procedure, and the test will be restarted.

\section{Material Required}

Propane, Hydrogen, or Natural Gas fuel.

\section{Test Setup}

- Follow the start up operating instructions for the fuel cell power plant being evaluated.

- Testing shall begin with the fuel cell power plant in the off - line mode.

- Prepare all data acquisition equipment for testing.

- Calculate the maximum sustained load, for the fuel cell power plant being evaluated, by decreasing the average of the Peak Load Test by 5\%.

- Round down the $95 \%$ calculated figure to the next value divisible by 50 watts.

- This calculated value will be the initial sustained load for this testing.

\section{Test Procedure}

1. Monitor the input of the fuel required by the fuel cell being tested. (Hydrogen, Natural Gas, etc.) Fuel cell output current (DC or AC), fuel cell output voltage (DC or AC), output load profile, air exhaust discharge rate, air exhaust discharge temperature, fuel cell stack temperature, and the ambient air temperature at the sampling rate as indicated in the data acquisition parameter table.

2. Turn on the fuel cell power plant being evaluated, according to the manufacturers operating instructions.

3. Add resistive load segments in 50 watt increments, remaining at each step for five (5) seconds. 
4. Continue increasing the load until the calculated maximum sustained peak load is reached.

5. Start recording.

6. Maintain the maximum sustained load for 60 minutes.

a. If a shutdown is experienced prior to the completion of the test, document the power level, time, and date.

b. If the fuel cell power plant being evaluated has shut down during the test, reduce the power level by $5 \%$, and round down to the next value divisible by 50 watts.

c. If the fuel cell power plant being evaluated operates continuously for $1 \mathrm{hr}$, increase the power requirement by $2.5 \%$, and begin the test procedure again.

7. Stop recording.

8. Restart the fuel cell power plant being evaluated to the on - line mode according to the manufacturers operating instructions.

9. Repeat steps 1 through 7, to achieve three (3) complete hour-long test runs.

10. Test data shall be maintained for only completed tests. Results will include both the sustained load level and the efficiency of the fuel cell in HHV and LHV units.

11. End test.

\section{Data Acquisition Parameters}

Table K1. Sustained load test, data acquisition parameters.

\begin{tabular}{|l|l|l|}
\hline $\begin{array}{l}\text { Electrical Information from } \\
\text { CTC Sensors. }\end{array}$ & $\begin{array}{l}\text { Fuel Supply Rate } \\
\text { from CTC Sensor }\end{array}$ & $\begin{array}{l}\text { Environmental Information } \\
\text { from CTC Sensors }\end{array}$ \\
\hline Sampling Rate 10 per second & $\begin{array}{l}\text { Sampling Rate 10 per sec- } \\
\text { ond }\end{array}$ & Sampling Rate 10 per second \\
\hline Gross Output, Stack Current & Inlet Fuel Mass Flow & Air Discharge Rate \\
\hline Net Output Current (AC or DC) & & Air Discharge Temperature \\
\hline Output Voltage (AC or DC) & & Ambient Air Temperature \\
\hline Output Load Profile & & Fuel Cell Stack Temperature \\
\hline
\end{tabular}




\section{Appendix L: Sustained Load Step Test}

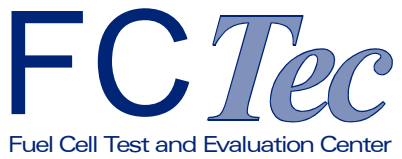

CTC Concurrent Technologies Corporation

\section{Test Plan For Residential Scale Fuel Cell Power Plants}

Title: Sustained Load Step Test

\begin{tabular}{|l|l|l|l|}
\hline Revision Letter & Author & Release No. & Date \\
\hline P. 1 & Jeffrey D. Stangl & Preliminary & January 31, 2003 \\
\hline & & & \\
\hline & & & \\
\hline & & & \\
\hline
\end{tabular}

\begin{tabular}{|l|l|l|l|}
\hline \multicolumn{2}{|l|}{ Product File Address: TBD } \\
\hline $\begin{array}{l}\text { Power Plant Manu- } \\
\text { facturer }\end{array}$ & System Tag No. & $\begin{array}{l}\text { Technology of the } \\
\text { Fuel Cell Power Plant }\end{array}$ & Document No. \\
\hline TBD & TBD & TBD & TBD \\
\hline
\end{tabular}

\section{Objective}

The purpose of the Sustained Load Step Test is to determine the fuel cell power plant capabilities of operating with impulse transitions, up to and including 100 percent of the sustained load that was determined during the sustained load test. Primary evaluation shall concentrate on the fuel cell's ability to supply power without the complicating factors of large inductive transients and large impulse current. Initial testing shall consist of various levels of resistive loading. 


\section{Length of Test}

The length of the test is dependent on where the fuel cell power plant fails while under test. (cf. Test Procedure and Table L1.)

\section{Material Required}

Propane, Hydrogen, or Natural Gas fuel.

\section{Daily Start Up I Pre - Test Review}

- Follow the start up operating instructions for the fuel cell power plant being evaluated.

- Testing shall begin with the fuel cell power plant in the off - line mode.

- Prepare all data acquisition equipment for testing.

- Determine the average sustained load, for the fuel cell power plant under evaluation, from the three completed Steady State, Sustained Load Tests.

- This value will be the $100 \%$ sustainable load for this testing.

- Divide this value by 20 to obtain a value that is $5 \%$ of the total. This value will be used as the incrementing value in the test.

\section{Test Procedure}

1. Monitor the input of the fuel required by the fuel cell being tested. (Hydrogen, Natural Gas, etc.) Fuel cell output current (DC or AC), fuel cell output voltage (DC or AC), output load profile, air exhaust discharge rate, air exhaust discharge temperature, fuel cell stack temperature, and the ambient air temperature at the sampling rate as indicated in the data acquisition parameter table.

2. Turn on the fuel cell power plant being evaluated, according to the manufacturers operating instructions.

3. Start recording.

4. Add resistive load segments in 50 watt sequences, remaining at each step for five (5) seconds.

5. Continue increasing the load until reaching the starting load point of the Sustained Load Test as indicated in Table 1.

6. Add a resistive load segment as indicated in Table 1.

7. Cycle this segment on and off, in increments of 1 second on, and 1 second off, for 60 seconds. 
a. If a shutdown is experienced any time during the execution of the test, stop recording, document the power level, time, and date.

b. If the fuel cell under evaluation has shut down during the test, decrease the additive load by $2.5 \%$ of the sustainable load, document the revision, and restart the test procedure.

c. If the fuel cell being evaluated operates continuously throughout each test, continue on with step nine of this test procedure.

8. Restart the fuel cell power plant being evaluated to the off - line mode according to the manufacturers operating instructions.

9. Repeat the entire test procedure until it has been completed three times successfully, to assure repeatability.

10. End test.

\section{Data Acquisition Parameters}

Table L1. Sustained load step test, data acquisition parameters.

\begin{tabular}{|l|l|l|}
\hline $\begin{array}{l}\text { Electrical Information from } \\
\text { CTC Sensors. }\end{array}$ & $\begin{array}{l}\text { Fuel Supply Rate } \\
\text { from CTC Sensor }\end{array}$ & $\begin{array}{l}\text { Environmental Information } \\
\text { from CTC Sensors }\end{array}$ \\
\hline Sampling Rate 10 per second & $\begin{array}{l}\text { Sampling Rate 10 per sec- } \\
\text { ond }\end{array}$ & Sampling Rate 10 per second \\
\hline Gross Output, Stack Current & Inlet Fuel Mass Flow & Air Discharge Rate \\
\hline Net Output Current (AC or DC) & & Air Discharge Temperature \\
\hline Output Voltage (AC or DC) & & Ambient Air Temperature \\
\hline Output Load Profile & & Fuel Cell Stack Temperature \\
\hline
\end{tabular}

Table L2. Sustained load step test, $100 \%$ sustained load capacity test.

\begin{tabular}{|c|c|c|c|c|c|}
\hline Test \# & Starting Load & Additive Load & Duration Seconds & $\begin{array}{l}\text { Total } \\
\text { Minutes }\end{array}$ & Comments \\
\hline 1 & 95\% Peak Load & $5 \%$ & 60 & 1 & \\
\hline 2 & 90\% Peak Load & $10 \%$ & 60 & 2 & \\
\hline 3 & 85\% Peak Load & $15 \%$ & 60 & 3 & \\
\hline 4 & 80\% Peak Load & $20 \%$ & 60 & 4 & \\
\hline 5 & 75\% Peak Load & $25 \%$ & 60 & 5 & \\
\hline 6 & 70\% Peak Load & $30 \%$ & 60 & 6 & \\
\hline 7 & $65 \%$ Peak Load & $35 \%$ & 60 & 7 & \\
\hline 8 & $60 \%$ Peak Load & $40 \%$ & 60 & 8 & \\
\hline 9 & 55\% Peak Load & $45 \%$ & 60 & 9 & \\
\hline 10 & 50\% Peak Load & $50 \%$ & 60 & 10 & \\
\hline 11 & 45\% Peak Load & $55 \%$ & 60 & 11 & \\
\hline 12 & 40\% Peak Load & $60 \%$ & 60 & 12 & \\
\hline 13 & 35\% Peak Load & $65 \%$ & 60 & 13 & \\
\hline
\end{tabular}




\begin{tabular}{|c|l|c|c|c|l|}
\hline Test \# & Starting Load & Additive Load & Duration Seconds & $\begin{array}{l}\text { Total } \\
\text { Minutes }\end{array}$ & Comments \\
\hline 14 & $30 \%$ Peak Load & $70 \%$ & 60 & 14 & \\
\hline 15 & $25 \%$ Peak Load & $75 \%$ & 60 & 15 & \\
\hline 16 & 20\% Peak Load & $80 \%$ & 60 & 16 & \\
\hline 17 & 15\% Peak Load & $85 \%$ & 60 & 17 & \\
\hline 18 & 10\% Peak Load & $90 \%$ & 60 & 18 & \\
\hline 19 & 5\% Peak Load & $95 \%$ & 60 & 19 & \\
\hline 20 & 0\% Peak Load & $100 \%$ & 60 & 20 & \\
\hline
\end{tabular}




\section{Appendix M: Overload Test}

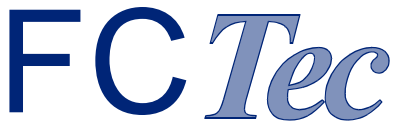

Fuel Cell Test and Evaluation Center

CTC Concurrent Technologies Corporation

\section{Test Plan For Residential Scale Fuel Cell Power Plants}

Title: Overload Test

\begin{tabular}{|l|l|l|l|}
\hline Revision Letter & Author & Release No. & Date \\
\hline P. 1 & Jeffrey D. Stangl & Preliminary & January 31, 2003 \\
\hline & & & \\
\hline & & & \\
\hline & & & \\
\hline
\end{tabular}

\begin{tabular}{|l|l|l|l|}
\hline \multicolumn{2}{|l|}{ Product File Address: TBD } \\
\hline $\begin{array}{l}\text { Power Plant Manu- } \\
\text { facturer }\end{array}$ & System Tag No. & $\begin{array}{l}\text { Technology of the } \\
\text { Fuel Cell Power Plant }\end{array}$ & Document No. \\
\hline TBD & TBD & TBD & TBD \\
\hline
\end{tabular}

\section{Objective}

The purpose of the Overload Test is to determine the fuel cell power plant's capability of operating with impulse transients up to 200 percent of the sustained load capacity. Primary evaluation shall concentrate on the fuel cell's ability to supply power without the complicating factors of large inductive transients and large impulse current. Initial testing shall consist of various levels of resistive loading. 


\section{Test Length}

The duration of the test is dependent on how many of the test tables are completed. Each of the six (6) test tables will require approximately 60 minutes to complete. Maximum test time assuming the power plant completes all six (6) tests is approximately 360 minutes.

\section{Material Required}

Propane, Hydrogen, or Natural Gas fuel.

\section{Test Setup}

- Follow the start up operating instructions for the fuel cell power plant being evaluated.

- Testing shall begin with the fuel cell power plant in the off - line mode.

- Prepare all data acquisition equipment for testing.

- Determine the average sustained load, for the fuel cell power plant under evaluation, from the three completed Steady State, Sustained Load Tests.

- Values of $10 \%, 20 \%, 30 \%, 40 \%, 50 \%$, and $100 \%$ shall be applied for this test.

\section{Test Procedure}

1. Monitor the input of the fuel required by the fuel cell being tested. (Hydrogen, Natural Gas, etc.) Fuel cell output current (DC or AC), fuel cell output voltage (DC or AC), output load profile, air exhaust discharge rate, air exhaust discharge temperature, fuel cell stack temperature, and the ambient air temperature at the sampling rate as indicated in the data acquisition parameter table.

2. Turn on the fuel cell power plant being evaluated, according to the manufacturers operating instructions.

3. Add resistive load in 50-watt increments, remaining at each step for five (5) seconds.

4. Continue increasing the load until reaching the starting load point of the Transient Test as indicated in Tables M1 through M6. The starting load point for this test shall be a percentage of the Sustained Load Test, which is indicated in the Starting Load column of Tables M1 through M6.

5. Start recording.

6. Add a resistive load segment as indicated in Tables M1 through M6. 
a. Remain at the designated percentage of load until the fuel cell power plant fails, or until 10 minutes have passed. Then stop recording.

b. If the fuel cell power plant fails, document the power level, duration of test until the failure occurred, time, and date. Then reduce the overload percentage by $5 \%$, and restart the test.

7. Restart the fuel cell power plant being evaluated to the off - line mode according to the manufacturers operating instructions.

8. Repeat the entire test procedure until all tests in Tables M1 through M6, have been completed three (3) times.

9. End test.

\section{Data Acquisition Parameters}

Table M1. Overload test, data acquisition parameters.

\begin{tabular}{|l|l|l|}
\hline \multicolumn{1}{|c|}{$\begin{array}{c}\text { Electrical Information from } \\
\text { CTC Sensors. }\end{array}$} & \multicolumn{1}{|c|}{$\begin{array}{c}\text { Fuel supply rate } \\
\text { From CTC sensor }\end{array}$} & \multicolumn{1}{c|}{$\begin{array}{c}\text { Environmental Information } \\
\text { From CTC sensors }\end{array}$} \\
\hline Sampling Rate 10 per second & Sampling Rate 10 per second & Sampling Rate 10 per second \\
\hline Gross Output, Stack Current & Inlet Fuel Mass Flow & Air Discharge Rate \\
\hline Net Output Current (AC or DC) & & Air Discharge Temperature \\
\hline Output Voltage (AC or DC) & & Ambient Air Temperature \\
\hline Output Load Profile & & Fuel Cell Stack Temperature \\
\hline
\end{tabular}

\section{Overload Test Tables}

Table M2. Overload test, $10 \%$ overload.

\begin{tabular}{|l|l|l|l|l|}
\hline Test \# & Starting Load & Additive Load & Duration Seconds & Comments \\
\hline 1 & $80 \%$ of Peak Load & $30 \%$ of Peak Load & & \\
\hline 2 & $60 \%$ of Peak Load & $50 \%$ of Peak Load & & \\
\hline 3 & $40 \%$ of Peak Load & $70 \%$ of Peak Load & & \\
\hline 4 & $20 \%$ of Peak Load & $90 \%$ of Peak Load & & \\
\hline 5 & $0 \%$ of Peak Load & $110 \%$ of peak Load & & \\
\hline
\end{tabular}

Table M3. Overload test, $20 \%$ overload.

\begin{tabular}{|l|l|l|l|l|}
\hline Test \# & Starting Load & Additive Load & Duration Seconds & Comments \\
\hline 1 & $80 \%$ of Peak Load & $40 \%$ of Peak Load & & \\
\hline 2 & $60 \%$ of Peak Load & $60 \%$ of Peak Load & & \\
\hline 3 & $40 \%$ of Peak Load & $80 \%$ of Peak Load & & \\
\hline 4 & $20 \%$ of Peak Load & $100 \%$ of Peak Load & & \\
\hline 5 & $0 \%$ of Peak Load & $120 \%$ of peak Load & & \\
\hline
\end{tabular}


Table M4. Overload test, $30 \%$ overload.

\begin{tabular}{|l|l|l|l|l|}
\hline Test \# & Starting Load & Additive Load & Duration Seconds & Comments \\
\hline 1 & $80 \%$ of Peak Load & $50 \%$ of Peak Load & & \\
\hline 2 & $60 \%$ of Peak Load & $70 \%$ of Peak Load & & \\
\hline 3 & $40 \%$ of Peak Load & $900 \%$ of Peak Load & & \\
\hline 4 & $20 \%$ of Peak Load & $110 \%$ of Peak Load & & \\
\hline 5 & $0 \%$ of Peak Load & $130 \%$ of peak Load & & \\
\hline
\end{tabular}

Table M5. Overload test, $40 \%$ overload.

\begin{tabular}{|l|l|l|l|l|}
\hline Test \# & Starting Load & Additive Load & Duration Seconds & Comments \\
\hline 1 & $80 \%$ of Peak Load & $60 \%$ of Peak Load & & \\
\hline 2 & $60 \%$ of Peak Load & $80 \%$ of Peak Load & & \\
\hline 3 & $40 \%$ of Peak Load & $100 \%$ of Peak Load & & \\
\hline 4 & $20 \%$ of Peak Load & $120 \%$ of Peak Load & & \\
\hline 5 & $0 \%$ of Peak Load & $140 \%$ of peak Load & & \\
\hline
\end{tabular}

Table M6. Overload test, $50 \%$ overload.

\begin{tabular}{|l|l|l|l|l|}
\hline Test \# & Starting Load & Additive Load & Duration Seconds & Comments \\
\hline 1 & $80 \%$ of Peak Load & $70 \%$ of Peak Load & & \\
\hline 2 & $60 \%$ of Peak Load & $90 \%$ of Peak Load & & \\
\hline 3 & $40 \%$ of Peak Load & $110 \%$ of Peak Load & & \\
\hline 4 & $20 \%$ of Peak Load & $130 \%$ of Peak Load & & \\
\hline 5 & $0 \%$ of Peak Load & $150 \%$ of peak Load & & \\
\hline
\end{tabular}

Table M7. Overload test, $100 \%$ overload

\begin{tabular}{|l|l|l|l|l|}
\hline Test \# & Starting Load & Additive Load & Duration Seconds & Comments \\
\hline 1 & $80 \%$ of Peak Load & $120 \%$ of Peak Load & & \\
\hline 2 & $60 \%$ of Peak Load & $140 \%$ of Peak Load & & \\
\hline 3 & $40 \%$ of Peak Load & $160 \%$ of Peak Load & & \\
\hline 4 & $20 \%$ of Peak Load & $180 \%$ of Peak Load & & \\
\hline 5 & $0 \%$ of Peak Load & $200 \%$ of peak Load & & \\
\hline
\end{tabular}




\section{Appendix N: Residential Profile Test}

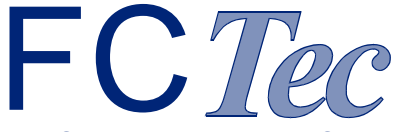

Fuel Cell Test and Evaluation Center

CTC Concurrent Technologies Corporation

\section{Test Plan For Residential Scale Fuel Cell Power Plants}

Title: Residential Profile Test

\begin{tabular}{|l|l|l|l|}
\hline Revision Letter & Author & Release No. & Date \\
\hline P. 1 & Jeffrey D. Stangl & Preliminary & January 31, 2003 \\
\hline & & & \\
\hline & & & \\
\hline & & & \\
\hline
\end{tabular}

\begin{tabular}{|l|l|l|l|}
\hline \multicolumn{2}{|l|}{ Product File Address: TBD } \\
\hline $\begin{array}{l}\text { Power Plant Manu- } \\
\text { facturer }\end{array}$ & System Tag No. & $\begin{array}{l}\text { Technology of the } \\
\text { Fuel Cell Power Plant }\end{array}$ & Document No. \\
\hline TBD & TBD & TBD & TBD \\
\hline
\end{tabular}

\section{Objective}

The purpose of the Residential Profile Test is to verify the fuel cell power plant's capability of operating in a residential setting, over a 5-day period. In this test, a profile will be established, and residential electrical appliances will be used to serve as the load. Loads and load changes shall be automated so that each fuel cell power plant being tested is subjected to the same load pattern. 


\section{Test Length}

The Residential Profile is anticipated to take $120 \mathrm{hrs}$ to complete. The test is planned to have a total of 480 steps at 15 minute intervals. (Reference Table N1 for an example of a $24 \mathrm{hr}$ test.)

\section{Material Required}

Propane, Hydrogen, or Natural Gas fuel.

\section{Test Setup}

- Follow the start up operating instructions for the fuel cell power plant being evaluated.

- Testing shall begin with the fuel cell power plant in the off - line mode.

- Prepare all data acquisition equipment for testing.

- The test shall run automated for five (5) days, to simulate power requirements for a typical one family residence, for a working family.

\section{Test Procedure}

1. Monitor the input of the fuel required by the fuel cell being tested. (Hydrogen, Natural Gas, etc.) Fuel cell output current (DC or AC), fuel cell output voltage (DC or AC), output load profile, air exhaust discharge rate, air exhaust discharge temperature, fuel cell stack temperature, and the ambient air temperature at the sampling rate as indicated in the data acquisition parameter table.

2. Turn on the fuel cell power plant being evaluated, according to the manufacturers operating instructions.

3. Begin recording.

4. Start the automated Residential Profile Test that will control the on/off switching of the load devices.

5. If the fuel cell power plant fails at any time during the test, document the power level, duration of the test, time and date. Then restart the test from the point of failure.

6. The test shall be complete at the end of the $5^{\text {th }}$ day.

7. End test. 


\section{Data Acquisition Parameters}

Table N1. Residential profile test. data acquisition parameters.

\begin{tabular}{|l|l|l|}
\hline $\begin{array}{l}\text { Electrical Information from } \\
\text { CTC Sensors. }\end{array}$ & $\begin{array}{l}\text { Fuel Supply Rate } \\
\text { from CTC Sensor }\end{array}$ & $\begin{array}{l}\text { Environmental Information } \\
\text { from CTC Sensors }\end{array}$ \\
\hline Sampling Rate 10 per second & $\begin{array}{l}\text { Sampling Rate 10 per sec- } \\
\text { ond }\end{array}$ & Sampling Rate 10 per second \\
\hline Gross Output, Stack Current & Inlet Fuel Mass Flow & Air Discharge Rate \\
\hline Net Output Current (AC or DC) & & Air Discharge Temperature \\
\hline Output Voltage (AC or DC) & & Ambient Air Temperature \\
\hline Output Load Profile & & Fuel Cell Stack Temperature \\
\hline
\end{tabular}




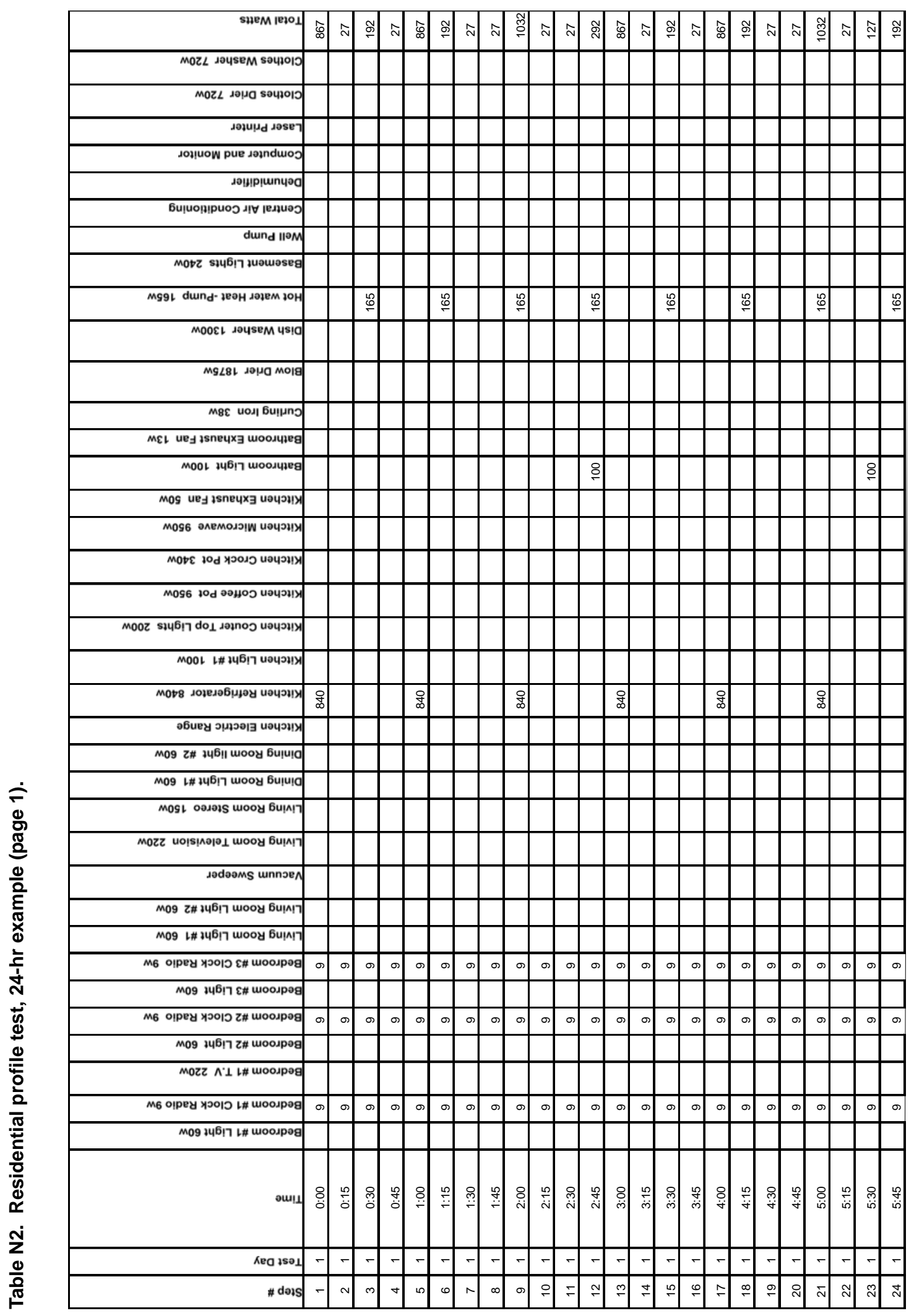




\begin{tabular}{|c|c|c|c|c|c|c|c|c|c|c|c|c|c|c|c|c|c|c|c|c|c|c|c|c|}
\hline 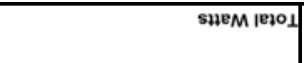 & \& & 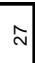 & స్తొ & 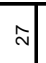 & $\begin{array}{l}\hat{0} \\
\infty\end{array}$ & 胥 & $\hat{N}$ & $\hat{N}$ & $\begin{array}{l}0 \\
\stackrel{\infty}{0} \\
\stackrel{\sim}{N}\end{array}$ & $\begin{array}{l}\infty \\
\vdots \\
\vdots \\
\vdots\end{array}$ & $\begin{array}{l}\stackrel{\iota}{0} \\
\stackrel{\circ}{\circ}\end{array}$ & $\begin{array}{l}\stackrel{2}{ } \\
\stackrel{7}{7}\end{array}$ & $\begin{array}{l}\hat{y} \\
\vec{y}\end{array}$ & 趈 & $\stackrel{\sim}{\sim}$ & 咸 & $\begin{array}{l}\text { ్ొ } \\
\text { ల్ }\end{array}$ & 茎 & సี & 菊 & 嫼 & ్ֶ & $\begin{array}{c}\mathbb{N} \\
\substack{-1 \\
-1}\end{array}$ & 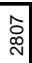 \\
\hline 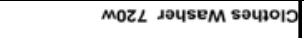 & & & & & & & & & & & & & & & & & ำ & ำ & ำ & 이 & & ำ & 에 & ลิ \\
\hline 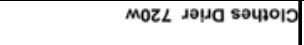 & & & & & & & & & & & & & & & & & & & & & 긴 & ని & ลิ & 긴 \\
\hline 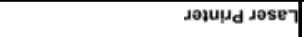 & & & & & & & & & & & & & & & & & & & & & & & & \\
\hline soluow pue seindwoo & & & & & & & & & & & & & & & & & & & & & & & & \\
\hline 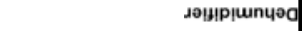 & & & & & & & & & & & & & & & & & & & & & & & & \\
\hline 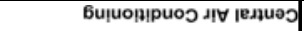 & & & & & & & & & & & & & & & & & & & & & & & & \\
\hline dund $\| \odot \mathrm{M}$ & & & & & & & & & & & & & & & & & & & & & & & & \\
\hline 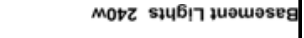 & & & & & & & & & & & & & & & & & 号 & & & & 吕 & 인 & & \\
\hline Mg9l dund- зеон дәзем зон & & & 唄 & & & 递 & & & 䍖 & & 杬 & & 恣 & & & 陉 & & & & 望 & & & & 唄 \\
\hline 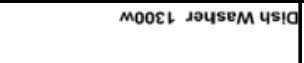 & & & & & & & & & & & & & 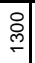 & 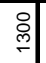 & 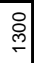 & $\begin{array}{l}\stackrel{9}{-} \\
\text { D. }\end{array}$ & 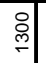 & : & 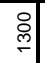 & 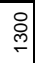 & & & & \\
\hline MgL8L دOHO MOIB & & & & & & & & & & 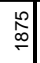 & $\begin{array}{c}0 \\
\infty \\
-\infty \\
\sim\end{array}$ & & & & & & & & & & & & & \\
\hline 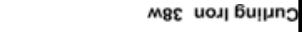 & & & & & & & & & & $\stackrel{\infty}{m}$ & & & & & & & & & & & & & & \\
\hline 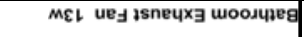 & & & & & & & & & ㄱ & $\stackrel{m}{\rightarrow}$ & $\stackrel{m}{\rightarrow}$ & $m$ & & & & & & & & & & & & \\
\hline 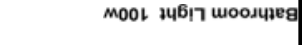 & & & & & & & & & : & 워 & 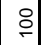 & 워 & 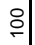 & & & & 위 & & & & 워 & & & \\
\hline 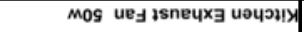 & & & & & & & & & & & & & & & & & & & & & & & & \\
\hline 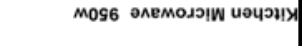 & & & & & & & & & & & 吕 & & & & & & & & & & & & & 吕 \\
\hline 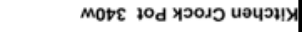 & & & & & & & & & & & & & & & & & & & & & & & & \\
\hline 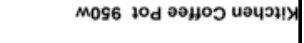 & & & & & & & & & 吕 & 양 & 양 & 吕 & 号 & 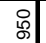 & & & & & & & & & & \\
\hline 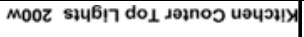 & & & & & & & & & o & 인 & o. & o & o. & & & & & & & & & & & \\
\hline Mo01 L\# & & & & & & & & & 이 & 의 & o. & 의 & ఏ. & : & & & & & o & & & & & \\
\hline 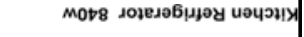 & 亭 & & & & o & & & & 吕 & & $\begin{array}{c}9 \\
⿱ 亠 乂 \\
\infty\end{array}$ & & o & & & & ơ & & & & 各 & & & \\
\hline 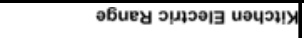 & & & & & & & & & & & & & & & & & & & & & & & & \\
\hline 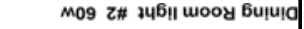 & & & & & & & & & & & & & & & & & & & & & & 8 & 8 & \\
\hline 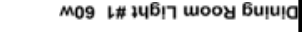 & & & & & & & & & & & & & : & ㅇ & & & & & & & & 8 & : & \\
\hline 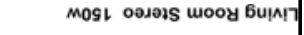 & & & & & & & & & เ & ـ & ๑ & ـ & م & ـ & เ & 几 & ـ & م & เ & ค & م & 几 & م & เ \\
\hline 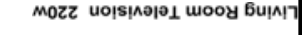 & & & & & & & & & & ิำ & సิ| & సิ & సి & ำ & สิ & సి & กิ & ลิ & ำ & సิ & సิ & సิ & సิ & సิ \\
\hline دәdøəMS unnכeN & & & & & & & & & & & & & & & : & & : & & : & & $:$ & & & \\
\hline 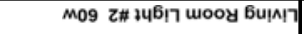 & & & & & & & & & & & & & ๑) & : & 8 & 8 & : & : & ㅇ & : & : & & & \\
\hline 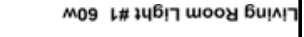 & & & & & & & & & & $:$ & $:$ & ¿ & $:$ & : & 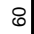 & 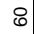 & : & 이 & : & 8 & : & & & \\
\hline 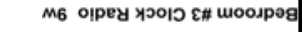 & a) & a & a) & का & a) & a & の & o & a & का & a) & का & の) & a) & $\sigma$ & a & a) & $\sigma$ & a) & a & a) & a & a) & a) \\
\hline 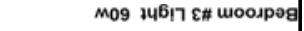 & & & & & & & & & 8 & ㅇ & : & : & : & : & & & 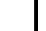 & & & 8 & : & & & \\
\hline 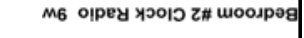 & a) & $\sigma$ & a) & a) & a) & a) & a & a & $\sigma$ & の) & ब & क) & の) & a) & a & a & a & $\sigma$ & का & $\sigma$ & a & a & a & $\sigma$ \\
\hline м09 зч6!ר Z\# woospog & & & & & & & & & 8 & : & : & : & & & & & & : & : & & & & & \\
\hline Mozz $\Lambda^{\prime} \perp \mathrm{L}$ \# woospag & & & & & & & & & & ิำ & సิ & & & & & & & & & & & & & \\
\hline 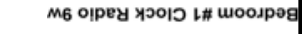 & a) & a & a) & の & a) & a) & a & a & का & ब & का & a) & の & a) & の & の & a & $\sigma$ & a & a & $\sigma$ & a & a & a \\
\hline м09 зчбб|า L\# woodp. & & & & & & & & & 8 & 8 & ৪ & & & & & 8 & 8 & & & & & & & \\
\hline काயI & $\begin{array}{l}\text { o. } \\
\dot{0}\end{array}$ & 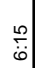 & $\begin{array}{l}0 \\
0 \\
0\end{array}$ & 骂 & 옷 & 虽 & 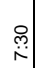 & 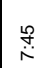 & 总 & 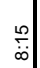 & $\underset{\substack{0 \\
\infty \\
\infty}}{\mid}$ & $\begin{array}{l}\substack{f \\
\infty \\
\infty} \\
\end{array}$ & o. & 号 & ্ֻলি & 卢 & $\begin{array}{l}\text { oे } \\
\vdots \\
\text { | }\end{array}$ & 号 & $\begin{array}{l}0 \\
\text { ôj } \\
\text { and }\end{array}$ & $\begin{array}{l}\stackrel{?}{f} \\
\stackrel{-}{0}\end{array}$ & 总 & 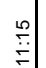 & $\begin{array}{c}\stackrel{0}{7} \\
\stackrel{7}{-1}\end{array}$ & 㹲 \\
\hline Kea isol & 7 & -1 & -1 & -1 & -1 & -1 & $\rightarrow$ & $\rightarrow$ & -1 & -1 & -1 & -1 & -1 & -1 & -1 & -1 & -1 & -1 & -1 & -1 & -1 & -1 & -1 & -1 \\
\hline \# dozs & $\stackrel{\llcorner}{N}$ & $\stackrel{\circ}{N}$ & $\hat{N}$ & $\stackrel{\infty}{\sim}$ & iे & 이 & $\vec{m}$ & ల్ & m & m & 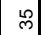 & 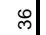 & $\hat{m}$ & $\stackrel{\infty}{\infty}$ & क् & q & 7 & รี & q & J & \& & gq & f & $\stackrel{\infty}{q}$ \\
\hline
\end{tabular}




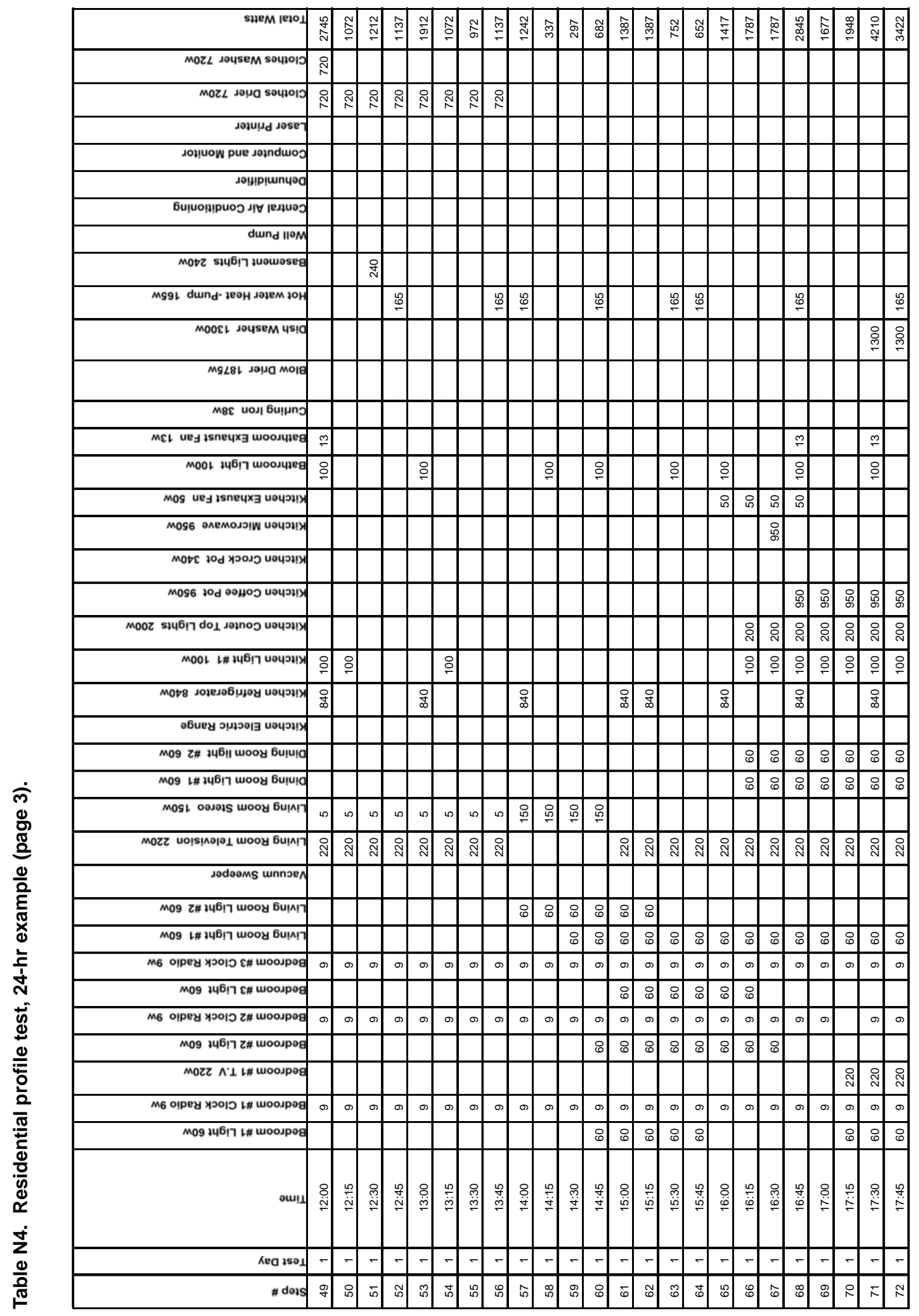




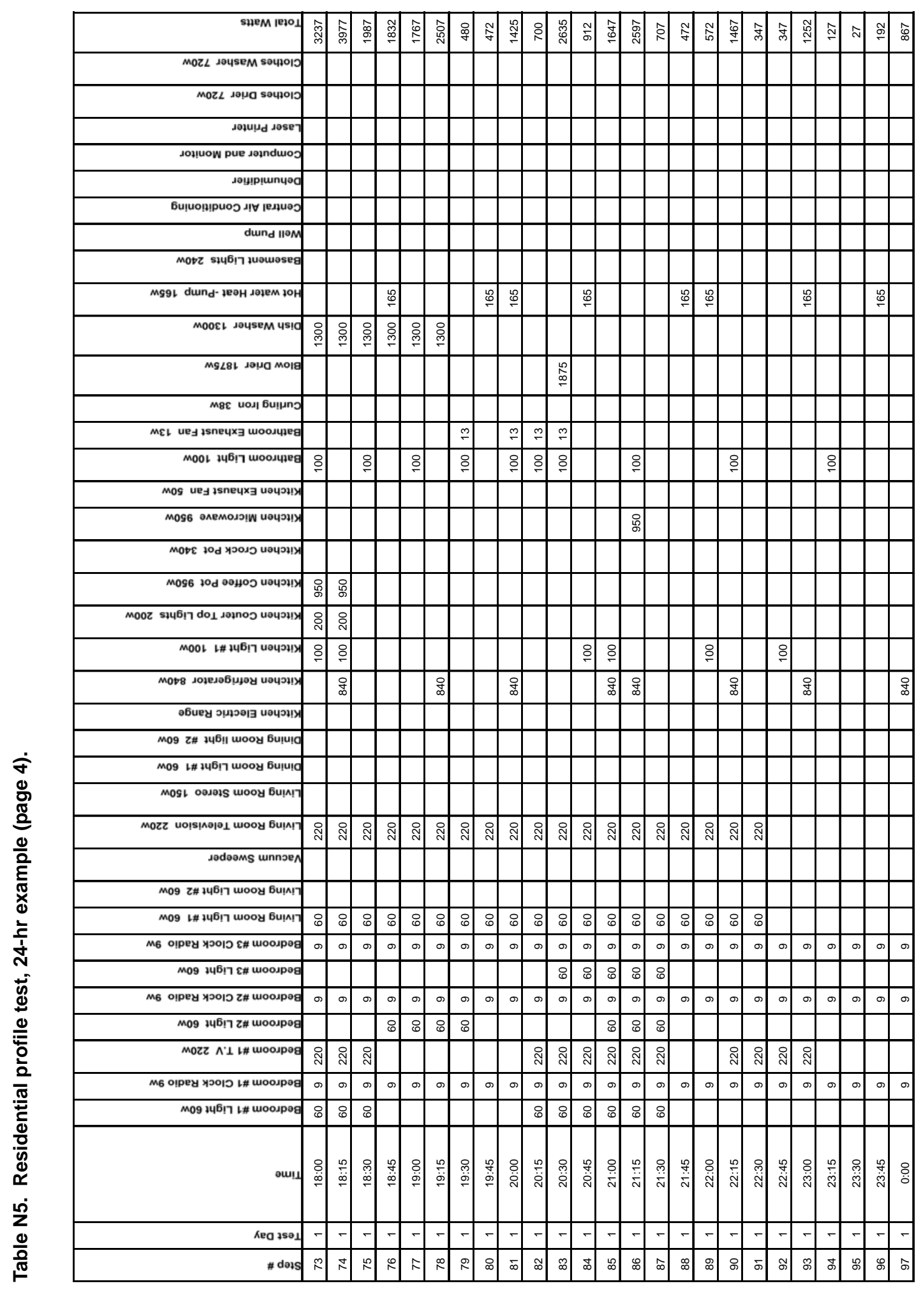




\section{Appendix 0: Residential Profile Test with Respect to Temperature and Humidity}

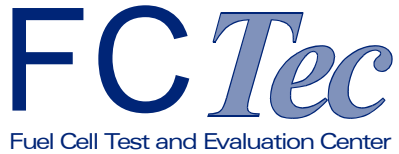

CTC Concurrent Technologies Corporation

Test Plan For Residential Scale Fuel Cell Power Plants

Title: Residential Profile Test with respect to Temperature and Humidity

\begin{tabular}{|l|l|l|l|}
\hline Revision Letter & Author & Release No. & Date \\
\hline P. 1 & Jeffrey D. Stangl & Preliminary & January 31, 2003 \\
\hline & & & \\
\hline & & & \\
\hline & & & \\
\hline
\end{tabular}

\begin{tabular}{|l|l|l|l|}
\hline \multicolumn{2}{|l|}{ Product File Address: TBD } \\
\hline $\begin{array}{l}\text { Power Plant Manu- } \\
\text { facturer }\end{array}$ & System Tag No. & $\begin{array}{l}\text { Technology of the } \\
\text { Fuel Cell Power Plant }\end{array}$ & Document No. \\
\hline TBD & TBD & TBD & TBD \\
\hline
\end{tabular}

\section{Objective}

The purpose of the Residential Profile with respect to Temperature and Humidity Test is to verify the fuel cell power plant's capability of operating in a residential setting, under conditions of high/low humidity, and high/low temperature over a 24 -hr period. The fuel cell power plant being evaluated shall be placed in the temperature and humidity chamber for testing. Table $\mathrm{O} 1$ lists the temperature and humidity settings for each test. The automated test (Steps 1 through 
96) of the Residential Profile Test shall be used for each of the Temperature and Humidity test periods. The timing for each load step during this segment will be reduced from 15 minutes to 5 minutes.

\section{Test Length}

The test article shall be operated over the residential load profile, reducing the time duration between load steps to 5 minutes. Each residential sequence shall operate at a minimum of 11 temperature steps distributed over the manufacturer's specified temperature range. Each temperature range shall be duplicated at the three levels of humidity as specified within the test table. Humidity capability will be bound by a $4^{\circ} \mathrm{C}$ dew point requirement on the environmental chamber, thus not allowing some humidity set points to be achieved. The load sequencing of the Residential Profile test shall be held at a steady state level during the transitioning of temperature and humidity set points.

\section{Material Required}

Propane, Hydrogen, or Natural Gas fuel.

\section{Test Setup}

- Follow the start up operating instructions for the fuel cell power plant being evaluated.

- Testing shall begin with the fuel cell power plant in the off - line mode.

- Prepare all data acquisition equipment for testing.

- The test shall run automated for 45 days, to simulate power requirements for a typical one family residence, for a working family.

\section{Test Procedure}

1. Monitor the input of the fuel required by the fuel cell being tested. (Hydrogen, Natural Gas, etc.) Fuel cell output current (DC or AC), fuel cell output voltage (DC or AC), output load profile, air exhaust discharge rate, air exhaust discharge temperature, fuel cell stack temperature, and the ambient air temperature at the sampling rate as indicated in the data acquisition parameter table.

2. Turn on the fuel cell power plant being evaluated, according to the manufacturers operating instructions.

3. Begin recording. 
4. Start the automated Residential Profile Test that will control the on/off switching of the load devices.

5. Control the environmental chamber to the specified temperature and humidity as required. Temperatures shall be determined by using a minimum of 11 steps distributed over the manufacturer's suggested temperature operating range.

6. If the fuel cell power plant fails at any time during the test, document the power level, duration of the test, time and date. Then restart the test from the point of failure.

7. Repeat steps 1 through 5 for each test. Efficiency will be reported as LHV and HHV for each hour of the test and, to the extent possible, curves will be developed as a function of ambient temperature and load.

8. End test after complete.

\section{Data Acquisition Parameters}

Table 01. Residential profile test, data acquisition parameters

\begin{tabular}{|l|l|l|}
\hline $\begin{array}{l}\text { Electrical Information from } \\
\text { CTC Sensors. }\end{array}$ & $\begin{array}{l}\text { Fuel Supply Rate } \\
\text { from CTC Sensor }\end{array}$ & $\begin{array}{l}\text { Environmental Information } \\
\text { from CTC Sensors }\end{array}$ \\
\hline Sampling Rate 10 per second & $\begin{array}{l}\text { Sampling Rate 10 per sec- } \\
\text { ond }\end{array}$ & Sampling Rate 10 per second \\
\hline Gross Output, Stack Current & Inlet Fuel Mass Flow & Air Discharge Rate \\
\hline Net Output Current (AC or DC) & & Air Discharge Temperature \\
\hline Output Voltage (AC or DC) & & Ambient Air Temperature \\
\hline Output Load Profile & & Fuel Cell Stack Temperature \\
\hline
\end{tabular}

Table 02. Residential profile test, temperature and humidity test table

\begin{tabular}{|l|c|c|}
\hline Test \# & Temperature ${ }^{\circ} \mathbf{F}$ & Humidity \% \\
\hline 1 & $50 \%$ of operating range & 50 \\
\hline 2 & $50 \%$ of operating range & 95 \\
\hline 3 & $50 \%$ of operating range & 20 \\
\hline 4 & $60 \%$ of operating range & 50 \\
\hline 5 & $60 \%$ of operating range & 95 \\
\hline 6 & $60 \%$ of operating range & 20 \\
\hline 7 & $70 \%$ of operating range & 50 \\
\hline 8 & $70 \%$ of operating range & 95 \\
\hline 9 & $70 \%$ of operating range & 20 \\
\hline 10 & $80 \%$ of operating range & 50 \\
\hline 11 & $80 \%$ of operating range & 95 \\
\hline 12 & $80 \%$ of operating range & 20 \\
\hline 13 & $90 \%$ of operating range & 50 \\
\hline 14 & $90 \%$ of operating range & 95 \\
\hline 15 & $90 \%$ of operating range & 20 \\
\hline 16 & $100 \%$ of operating range & 50 \\
\hline 17 & $100 \%$ of operating range & \\
\hline
\end{tabular}




\begin{tabular}{|l|c|c|}
\hline Test \# & Temperature ${ }^{\circ} \mathbf{F}$ & Humidity \% \\
\hline 18 & $100 \%$ of operating range & 20 \\
\hline 19 & $40 \%$ of operating range & 50 \\
\hline 20 & $40 \%$ of operating range & 95 \\
\hline 21 & $40 \%$ of operating range & 20 \\
\hline 22 & $30 \%$ of operating range & 50 \\
\hline 23 & $30 \%$ of operating range & 95 \\
\hline 24 & $30 \%$ of operating range & 20 \\
\hline 25 & $20 \%$ of operating range & 50 \\
\hline 26 & $20 \%$ of operating range & 95 \\
\hline 27 & $20 \%$ of operating range & 20 \\
\hline 28 & $10 \%$ of operating range & 50 \\
\hline 29 & $10 \%$ of operating range & 95 \\
\hline 30 & $10 \%$ of operating range & 20 \\
\hline 31 & Lowest operating point & 50 \\
\hline 32 & Lowest operating point & 95 \\
\hline 33 & Lowest operating point & No requirements \\
\hline $\begin{array}{l}\text { Freeze durability with test article } \\
\text { shutdown and prepared as manufac- } \\
\text { turers requirements }\end{array}$ & Lowest operating point & \\
\hline
\end{tabular}




\section{Appendix P: Combined Heat and Power Test}

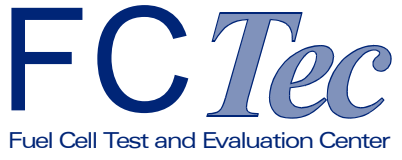

CTC Concurrent Technologies Corporation

\section{Test Plan For Residential Scale Fuel Cell Power Plants}

Title: Combined Heat and Power Test

\begin{tabular}{|l|l|l|l|}
\hline Revision Letter & Author & Release No. & Date \\
\hline P. 1 & Jeffrey D. Stangl & Preliminary & January 31, 2003 \\
\hline & & & \\
\hline & & & \\
\hline Product File Address: & TBD & & Document No. \\
\hline $\begin{array}{l}\text { Power Plant Manu- } \\
\text { facturer }\end{array}$ & System Tag No. & $\begin{array}{l}\text { Technology of the } \\
\text { Fuel Cell Power Plant }\end{array}$ & TBD \\
\hline TBD & TBD & TBD & \\
\hline
\end{tabular}

\section{Objective}

The purpose of the Combined Heat and Power Test is to measure and map the thermal output of a given Fuel Cell Power Plant under various load conditions. A Thermal Load Bank with all of the appropriate measurement and control devices will be used as the testing device.

\section{Length of Test}

The length of this test will be approximately 25 testing hours plus the initial start up time of the fuel cell. 


\section{Material Required}

Propane, Hydrogen, or Natural Gas fuel.

\section{Test Setup}

- Follow the start up procedure in the operating instructions of the fuel cell power plant being evaluated.

- Set the output power of the FCPP to the first step output power shown in the Combined Heat and Power test table.

- Prepare all data acquisition equipment for testing and begin recording.

\section{Test Procedure}

1. Monitor the data collected by the measurement devices in Data Acquisition Parameters table.

2. Capture data that the FCPP computer system and sensors collect.

3. Start recording.

4. Turn the fuel cell to be evaluated on according to the manufacturer instructions.

5. Follow the Combined Heat and Power test table.

6. Stop recording.

7. A map will be developed showing thermal recovery in Btu/Hr on the vertical axis and return temperature from the load to the fuel cell in degrees Fahrenheit $\left({ }^{\circ} \mathrm{F}\right)$ on the horizontal axis with curves for various constant supply temperatures from the fuel cell to the load in increments of $10^{\circ} \mathrm{F}$ for data developed during the test variable parameters.

8. Tests will be conducted while maintaining a $60^{\circ} \mathrm{F}$, an $80^{\circ} \mathrm{F}$, and a $100^{\circ} \mathrm{F}$ return temperature to the fuel cell.

\section{Data Acquisition Parameters}

Table P1. Combined heat and power test, data acquisition parameters.

\begin{tabular}{|l|l|l|}
\hline $\begin{array}{c}\text { Electrical Information from } \\
\text { CTC or Manufactures Sensors. }\end{array}$ & \multicolumn{1}{|c|}{$\begin{array}{c}\text { Fuel Supply Rate } \\
\text { From CTC Sensor }\end{array}$} & $\begin{array}{c}\text { Environmental Information } \\
\text { from CTC or Manufacturers } \\
\text { Sensors }\end{array}$ \\
\hline Sampling Rate 10 per second & Sampling Rate 10 per second & Sampling Rate 10 per second \\
\hline Gross Output, Stack Current & Inlet Fuel Mass Flow & Air Discharge Rate \\
\hline Net Output Current (AC or DC) & & Air Discharge Temperature \\
\hline Output Voltage (AC or DC) & & Ambient Air Temperature \\
\hline Output Load Profile & & Fuel Cell Stack Temperature \\
\hline Process Flow Rate & & \\
\hline
\end{tabular}




\begin{tabular}{|l|l|l|}
\hline $\begin{array}{c}\text { Electrical Information from } \\
\text { CTC or Manufactures Sensors. }\end{array}$ & $\begin{array}{c}\text { Fuel Supply Rate } \\
\text { From CTC Sensor }\end{array}$ & $\begin{array}{c}\text { Environmental Information } \\
\text { from CTC or Manufacturers } \\
\text { Sensors }\end{array}$ \\
\hline Chilled water Flow rate & & \\
\hline Hot side system inlet temperature & & \\
\hline Hot side system outlet temperature & & \\
\hline Cold side system inlet temperature & & \\
\hline Cold side system outlet temperature & & \\
\hline
\end{tabular}

Table P2. Combined heat and power test.

\begin{tabular}{|c|c|c|c|}
\hline Step \# & FCPP Power Output & Time at step & Process Water Flow Rate \\
\hline 1 & $20 \%$ of Max output & 1 Hour & $5 \%$ of max Flow Rate \\
\hline 2 & $20 \%$ of Max output & 1 Hour & $10 \%$ of max Flow Rate \\
\hline 3 & $20 \%$ of Max output & 1 Hour & $20 \%$ of max Flow Rate \\
\hline 4 & $20 \%$ of Max output & 1 Hour & $40 \%$ of max Flow Rate \\
\hline 5 & $20 \%$ of Max output & 1 Hour & $60 \%$ of max Flow Rate \\
\hline 6 & $20 \%$ of Max output & 1 Hour & $80 \%$ of max Flow Rate \\
\hline 7 & $20 \%$ of Max output & 1 Hour & $100 \%$ of max Flow Rate \\
\hline 8 & $40 \%$ of Max output & 1 Hour & $5 \%$ of max Flow Rate \\
\hline 9 & $40 \%$ of Max output & 1 Hour & $10 \%$ of max Flow Rate \\
\hline 10 & $40 \%$ of Max output & 1 Hour & $20 \%$ of max Flow Rate \\
\hline 11 & $40 \%$ of Max output & 1 Hour & $40 \%$ of max Flow Rate \\
\hline 12 & $40 \%$ of Max output & 1 Hour & $60 \%$ of max Flow Rate \\
\hline 13 & $40 \%$ of Max output & 1 Hour & $80 \%$ of max Flow Rate \\
\hline 14 & $40 \%$ of Max output & 1 Hour & $100 \%$ of max Flow Rate \\
\hline 15 & $60 \%$ of Max output & 1 Hour & $5 \%$ of max Flow Rate \\
\hline 16 & $60 \%$ of Max output & 1 Hour & $10 \%$ of max Flow Rate \\
\hline 17 & $60 \%$ of Max output & 1 Hour & $20 \%$ of max Flow Rate \\
\hline 18 & $60 \%$ of Max output & 1 Hour & $40 \%$ of max Flow Rate \\
\hline 19 & $60 \%$ of Max output & 1 Hour & $60 \%$ of max Flow Rate \\
\hline 20 & $60 \%$ of Max output & 1 Hour & $80 \%$ of max Flow Rate \\
\hline 21 & $60 \%$ of Max output & 1 Hour & $100 \%$ of max Flow Rate \\
\hline 22 & $80 \%$ of Max output & 1 Hour & $5 \%$ of max Flow Rate \\
\hline 23 & $80 \%$ of Max output & 1 Hour & $10 \%$ of max Flow Rate \\
\hline 24 & $80 \%$ of Max output & 1 Hour & $20 \%$ of max Flow Rate \\
\hline 25 & $80 \%$ of Max output & 1 Hour & $40 \%$ of max Flow Rate \\
\hline 26 & $80 \%$ of Max output & 1 Hour & $60 \%$ of max Flow Rate \\
\hline 27 & $80 \%$ of Max output & 1 Hour & $80 \%$ of max Flow Rate \\
\hline 28 & $80 \%$ of Max output & 1 Hour & $100 \%$ of max Flow Rate \\
\hline 29 & $100 \%$ of Max output & 1 Hour & $5 \%$ of max Flow Rate \\
\hline 30 & $100 \%$ of Max output & 1 Hour & $10 \%$ of max Flow Rate \\
\hline 31 & $100 \%$ of Max output & 1 Hour & $20 \%$ of max Flow Rate \\
\hline 32 & $100 \%$ of Max output & 1 Hour & $40 \%$ of max Flow Rate \\
\hline 33 & $100 \%$ of Max output & 1 Hour & $60 \%$ of max Flow Rate \\
\hline 34 & $100 \%$ of Max output & 1 Hour & $80 \%$ of max Flow Rate \\
\hline 35 & $100 \%$ of Max output & 1 Hour & $100 \%$ of max Flow Rate \\
\hline
\end{tabular}

NOTE: The maximum flow rate of the process water shall be the lower of: the maximum process flow rate of the fuel cell being evaluated, or the flow rate giving a $100{ }^{\circ} \mathrm{F}$ outlet at a $60^{\circ} \mathrm{F}$ inlet, or the maximum flow rate of the thermal load bank which is $15 \mathrm{gpm}$. 


\section{Appendix Q: 15 Amp Circuit Breaker Overload Test}

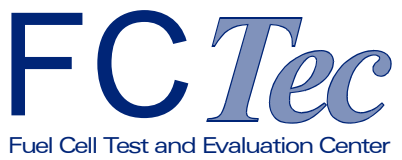

CTC Concurrent Technologies Corporation

\section{Test Plan For Residential Scale Fuel Cell Power Plants}

Title: 15 Amp Circuit Breaker Overload Test

\begin{tabular}{|l|l|l|l|}
\hline Revision Letter & Author & Release No. & Date \\
\hline P. 1 & Jeffrey D. Stangl & Preliminary & January 31, 2003 \\
\hline & & & \\
\hline & & & \\
\hline Product File Address: & TBD & & Document No. \\
\hline $\begin{array}{l}\text { Power Plant Manu- } \\
\text { facturer }\end{array}$ & System Tag No. & $\begin{array}{l}\text { Technology of the Fuel Cell } \\
\text { Power Plant }\end{array}$ & TBD \\
\hline TBD & TBD & TBD & \\
\hline
\end{tabular}

\section{Objective}

The objective of the 15 Amp Breaker Overload Test is to determine the fuel cell power plants capability to successfully open a 15 -amp breaker under an overload condition, while maintaining power to circuits that are not overloaded.

\section{Test Length}

The length of the test will depend on the ability of the fuel cell power plant to trip 
15-amp breaker without the complicating factor of an inverter, or power plant shutdown.

Maximum test time is anticipated to be 15.5 minutes. (Reference Table Q1.)

\section{Material Required}

Propane, Hydrogen, or Natural Gas fuel.

\section{Test Setup}

- Follow the start up operating instructions for the fuel cell power plant being evaluated.

- Testing shall begin with the fuel cell power plant in the off - line mode.

- Prepare all data acquisition equipment for testing.

- Prepare two electronic load banks for test procedure in accordance with manufacturer instructions.

\section{Test Procedure}

1. Monitor the input of the fuel required by the fuel cell being tested. (Hydrogen, Natural Gas, etc.) Fuel cell output current (DC or AC), fuel cell output voltage (DC or AC), electronic load bank \# 1 current, electronic load bank \# 2 current, air exhaust discharge rate, air exhaust discharge temperature, fuel cell stack temperature, and the ambient air temperature at the sampling rate as indicated in the data acquisition parameter table.

2. Turn on the fuel cell power plant being evaluated, according to the manufacturers operating instructions.

3. Start recording.

4. Set number one electronic load bank to a constant current of 25 amps.

5. Set number two electronic load bank to constant current, and increase the current in.

5 amp increments every 30 seconds until the circuit breaker trips, or until the fuel cell power plant fails.

6. Repeat test three times to obtain a pattern of repeatability.

7. Testing report shall include voltage to load curves. 


\section{Data Acquisition Parameters}

Table Q1. Fifteen (15) amp circuit breaker overload test, data acquisition parameters.

\begin{tabular}{|l|l|l|}
\hline $\begin{array}{l}\text { Electrical Information from } \\
\text { CTC Sensors. }\end{array}$ & $\begin{array}{l}\text { Fuel Supply Rate } \\
\text { from CTC Sensor }\end{array}$ & $\begin{array}{l}\text { Environmental Information } \\
\text { from CTC Sensors }\end{array}$ \\
\hline Sampling Rate 10 per second & $\begin{array}{l}\text { Sampling Rate 10 per sec- } \\
\text { ond }\end{array}$ & Sampling Rate 10 per second \\
\hline Gross Output, Stack Current & Inlet Fuel Mass Flow & Air Discharge Rate \\
\hline Net Output Current (AC or DC) & & Air Discharge Temperature \\
\hline Output Voltage (AC or DC) & & Ambient Air Temperature \\
\hline Electronic Load Bank \# 1 Current & & Fuel Cell Stack Temperature \\
\hline Electronic Load Bank \# 2 Current & & \\
\hline
\end{tabular}

Table Q2. Fifteen (15) amp circuit breaker overload test.

\begin{tabular}{|c|c|c|c|c|}
\hline Test \# & $\begin{array}{c}\text { Test Time } \\
\text { Minute/Seconds }\end{array}$ & $\begin{array}{l}\text { Load Bank \# } 1 \\
30 \text { amp Breaker }\end{array}$ & $\begin{array}{c}\text { Load Bank \# } 215 \\
\text { amp Breaker }\end{array}$ & $\begin{array}{l}15 \text { amp Breaker } \\
\text { Failure (Yes/No) }\end{array}$ \\
\hline 1 & $0: 30$ & 25 amps & $0.5 \mathrm{amp}$ & \\
\hline 2 & $1: 30$ & 25 amps & $1.0 \mathrm{amp}$ & \\
\hline 3 & 2:00 & 25 amps & $1.5 \mathrm{amps}$ & \\
\hline 4 & $2: 30$ & 25 amps & $2.0 \mathrm{amps}$ & \\
\hline 5 & 3:00 & 25 amps & $2.5 \mathrm{amps}$ & \\
\hline 6 & $3: 30$ & 25 amps & $3.0 \mathrm{amps}$ & \\
\hline 7 & 4:00 & 25 amps & 3.5 amps & \\
\hline 8 & $4: 30$ & 25 amps & $4.0 \mathrm{amps}$ & \\
\hline 9 & 5:00 & 25 amps & 4.5 amps & \\
\hline 10 & $5: 30$ & 25 amps & $5.0 \mathrm{amps}$ & \\
\hline 11 & $6: 00$ & 25 amps & 5.5 amps & \\
\hline 12 & $6: 30$ & 25 amps & 6.0 amps & \\
\hline 13 & 7:00 & 25 amps & 6.5 amps & \\
\hline 14 & $7: 30$ & 25 amps & $7.0 \mathrm{amps}$ & \\
\hline 15 & 8:00 & 25 amps & 7.5 amps & \\
\hline 16 & $8: 30$ & 25 amps & 8.0 amps & \\
\hline 17 & 9:00 & 25 amps & 8.5 amps & \\
\hline 18 & 9:30 & 25 amps & 9.0 amps & \\
\hline 19 & $10: 00$ & 25 amps & 9.5 amps & \\
\hline 20 & $10: 30$ & 25 amps & $10.0 \mathrm{amps}$ & \\
\hline 21 & $11: 00$ & 25 amps & $10.5 \mathrm{amps}$ & \\
\hline 22 & $11: 30$ & 25 amps & $11.0 \mathrm{amps}$ & \\
\hline 23 & $12: 00$ & 25 amps & $11.5 \mathrm{amps}$ & \\
\hline 24 & $12: 30$ & 25 amps & $12.0 \mathrm{amps}$ & \\
\hline 25 & $13: 00$ & 25 amps & $12.5 \mathrm{amps}$ & \\
\hline 26 & $13: 30$ & 25 amps & $13.0 \mathrm{amps}$ & \\
\hline 27 & $14: 00$ & 25 amps & 13.5 amps & \\
\hline 28 & $14: 30$ & 25 amps & $14.0 \mathrm{amps}$ & \\
\hline 29 & $15: 00$ & 25 amps & 14.5 amps & \\
\hline 30 & $15: 30$ & 25 amps & 15.0 amps & \\
\hline
\end{tabular}




\begin{tabular}{|l|c|c|c|c|}
\hline Test \# & $\begin{array}{c}\text { Test Time } \\
\text { Minute/Seconds }\end{array}$ & $\begin{array}{c}\text { Load Bank \# 1 } \\
\text { 30 amp Breaker }\end{array}$ & $\begin{array}{c}\text { Load Bank \# 2 15 } \\
\text { amp Breaker }\end{array}$ & $\begin{array}{c}\text { 15 amp Breaker } \\
\text { Failure (Yes/No) }\end{array}$ \\
\hline 31 & $16: 00$ & $25 \mathrm{amps}$ & $15.5 \mathrm{amps}$ & \\
\hline 32 & $16: 30$ & $25 \mathrm{amps}$ & $16.0 \mathrm{amps}$ & \\
\hline 33 & $17: 00$ & $25 \mathrm{amps}$ & $16.5 \mathrm{amps}$ & \\
\hline 34 & $17: 30$ & $25 \mathrm{amps}$ & $17.0 \mathrm{amps}$ & \\
\hline 35 & $18: 00$ & $25 \mathrm{amps}$ & $17.5 \mathrm{amps}$ & \\
\hline 36 & $18: 30$ & $25 \mathrm{amps}$ & $18.0 \mathrm{amps}$ & \\
\hline 37 & $19: 00$ & $25 \mathrm{amps}$ & $18.5 \mathrm{amps}$ & \\
\hline 38 & $19: 30$ & $25 \mathrm{amps}$ & $19.0 \mathrm{amps}$ & \\
\hline 39 & $20: 00$ & $25 \mathrm{amps}$ & $19.5 \mathrm{amps}$ & \\
\hline 40 & $21: 30$ & $25 \mathrm{amps}$ & $20 \mathrm{amps}$ & \\
\hline
\end{tabular}




\section{Appendix R: 15 Amp Breaker Short Circuit Test}

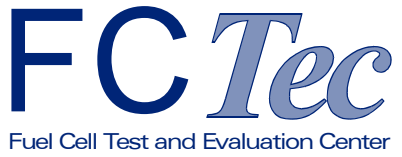

CTC Concurrent Technologies Corporation

\section{Test Plan For Residential Scale Fuel Cell Power Plants}

Title: 15 Amp Breaker Short Circuit Test

\begin{tabular}{|l|l|l|l|}
\hline Revision Letter & Author & Release No. & Date \\
\hline P. 1 & Jeffrey D. Stangl & Preliminary & January 31, 2003 \\
\hline & & & \\
\hline & \multicolumn{3}{|l}{} \\
\hline Product File Address: TBD & & Document No. \\
\hline \begin{tabular}{l|l|l|l|} 
Power Plant Manu- \\
facturer
\end{tabular} & System Tag No. & $\begin{array}{l}\text { Technology of the } \\
\text { Fuel Cell Power Plant }\end{array}$ & TBD \\
\hline TBD & TBD & TBD & \\
\hline
\end{tabular}

\section{Objective}

The objective of the 15 Amp Breaker-Short Circuit Test is to determine the fuel cell power plants capability to successfully open a 15 -amp breaker when subjected to a short circuit, while maintaining power to other circuits.

\section{Test Length}

The length of the test will depend on the ability of the fuel cell power plant to trip a 15-amp breaker without the complicating factor of an inverter, or power plant shutdown. 


\section{Material Required}

Propane Hydrogen, or Natural Gas fuel.

\section{Test Setup}

- Follow the start up operating instructions for the fuel cell power plant being evaluated.

- Testing shall begin with the fuel cell power plant in the off - line mode.

- Prepare all data acquisition equipment for testing.

- Prepare the electronic load bank to operate with a load of 25 amps for test procedure in accordance with manufacturers instructions.

- Prepare a resistive load bank of paralleled 100-watt light bulbs and switches, with a paralleled shorting switch for the test.

\section{Test Procedure}

1. Monitor the input of the fuel required by the fuel cell being tested. (Hydrogen, Natural Gas, etc.) Fuel cell output current (DC or AC), fuel cell output voltage (DC or AC), electronic load bank current, resistive load bank current, air exhaust discharge rate, air exhaust discharge temperature, fuel cell stack temperature, and the ambient air temperature at the sampling rate as indicated in the data acquisition parameter table.

2. Turn on the fuel cell power plant being evaluated, according to the manufacturers operating instructions.

3. Start recording.

4. Set static load on electronic load bank to a constant current of 25 amps.

5. Record the output voltage of the 15 -amp breaker to be subjected to the short circuit.

6. Short the 15 -amp breaker.

7. Record the status of the breaker after it was subjected to the short.

8. Record the status of the fuel cell and inverter including the voltage over time curve.

9. Repeat test three times to obtain a pattern of repeatability.

10. Repeat the test procedure using a setting of the electronic load bank to the load determined by the result of the Sustained Load Test. 


\section{Data Acquisition Parameters}

Table R1. Fifteen (15) amp breaker short circuit test, data acquisition parameters.

\begin{tabular}{|l|l|l|}
\hline $\begin{array}{l}\text { Electrical Information from } \\
\text { CTC Sensors. }\end{array}$ & $\begin{array}{l}\text { Fuel Supply Rate } \\
\text { from CTC Sensor }\end{array}$ & $\begin{array}{l}\text { Environmental Information } \\
\text { from CTC Sensors }\end{array}$ \\
\hline Sampling Rate 10 per second & Sampling Rate 10 per second & Sampling Rate 10 per second \\
\hline Gross Output, Stack Current & Inlet Fuel Mass Flow & Air Discharge Rate \\
\hline Net Output Current (AC or DC) & & Air Discharge Temperature \\
\hline Output Voltage (AC or DC) & & Ambient Air Temperature \\
\hline Electronic Load Bank Current & & Fuel Cell Stack Temperature \\
\hline Short Circuit Current & & \\
\hline $\begin{array}{l}\text { Short Circuit - Breaker Output } \\
\text { Voltage }\end{array}$ & & \\
\hline
\end{tabular}

Table R2. Fifteen (15) amp breaker short circuit test, short circuit test table.

\begin{tabular}{|l|l|l|l|}
\hline Test \# & Electronic Load Bank Current & Shorting Circuit Status & $\begin{array}{l}\text { Shorting Circuit Breaker } \\
\text { Output Voltage }\end{array}$ \\
\hline 1 & 25 amps & Open & \\
\hline 2 & 25 amps & Closed & \\
\hline
\end{tabular}




\section{Appendix S: Power Grid Simulation Test}

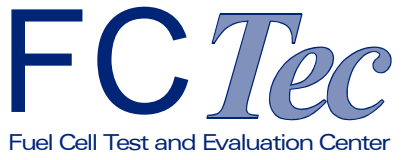

CTC Concurrent Technologies Corporation

\section{Test Plan For Residential Scale Fuel Cell Power Plants}

Title: Power Grid Simulation Test

\begin{tabular}{|l|l|l|l|}
\hline Revision Letter & Author & Release No. & Date \\
\hline P. 1 & Jeffrey D. Stangl & Preliminary & January 31, 2003 \\
\hline & & & \\
\hline & & & \\
\hline & & & \\
\hline
\end{tabular}

\begin{tabular}{|l|l|l|l|}
\hline \multicolumn{2}{|l|}{ Product File Address: TBD } \\
\hline $\begin{array}{l}\text { Power Plant Manu- } \\
\text { facturer }\end{array}$ & System Tag No. & $\begin{array}{l}\text { Technology of the } \\
\text { Fuel Cell Power Plant }\end{array}$ & Document No. \\
\hline TBD & TBD & TBD & TBD \\
\hline
\end{tabular}

\section{Objective}

The objective of Grid Simulation is to develop a characteristic profile for a given residential scale fuel cell power plant, specifically how it operates with respect to grid variations. Variations, such as simultaneous or independent transients, voltage surges/sags, frequency deviation, voltage phase differentiation, and waveform distortion. 


\section{Test Length}

A total of five (5) tests are planned; each will vary in duration. (Reference Test Procedures and Tables S1, S2, and S3 for duration of each test.)

\section{Material Required}

Propane Hydrogen or Natural Gas fuel.

\section{Test Setup}

- Follow the start up operating instructions for the fuel cell power plant being evaluated.

- Testing shall begin with the fuel cell power plant in the off - line mode.

- Prepare all data acquisition equipment for testing.

- Prepare the Grid Simulator for testing according to the manufacturer instructions.

\section{Test Procedure}

1. Monitor the input of the fuel required by the fuel cell being tested. (Hydrogen, Natural Gas, etc.) Fuel cell output current (DC or AC), fuel cell output voltage (DC or AC), electronic load bank current, resistive load bank current, air exhaust discharge rate, air exhaust discharge temperature, fuel cell stack temperature, and the ambient air temperature at the sampling rate as indicated in the data acquisition parameter table.

2. Turn on the fuel cell power plant being evaluated, according to the manufacturers operating instructions.

3. Turn on resistive load bank and set the related circuit parameters so that the fuel cell sees a $\mathrm{Q}$ of 2.5 at $60 \mathrm{~Hz}$.

4. Start Recording.

5. For each test a graph will be prepared showing the test parameter and the fuel cell voltage output and timing during shutdown or disconnect.

6. Perform the following grid simulation tests according to the respective procedure and Test Tables. 


\section{Test 1-Frequency Deviation Test}

1. The grid simulator shall be initially set to operate to the fuel cell power plant grid independent output frequency.

2. Equally distribute a total load of $50 \%$ of capacity across both legs of the fuel cell power plant output if applicable.

3. The time spent at each step shall be one minute.

4. Increase the Grid Simulator Frequency by .01 Hz increments a minute above an initial setting of $60 \mathrm{~Hz}$.

5. Increase the frequency until the fuel cell power plant shuts down, or the fuel cell power plant goes into grid independent mode.

6. Reset the Grid Simulator to the Fuel Cell Power Plant frequency and if necessary restart the fuel cell power plant.

7. Decrease the Grid Simulator frequency by .01 HZ, and remain at each new frequency value for one minute.

8. Decrease the frequency until the total decreased value is $1 \mathrm{~Hz}$, the fuel cell power plant shuts down, or the fuel cell power plant goes into grid independent mode.

9. Reset the Grid Simulator to the starting frequency and, if necessary, restart the fuel cell power plant.

10. Repeat Frequency Deviation Test three times to obtain a pattern of repeatability.

\section{Test 2-Voltage Sag/Surge Test}

1. Equally distribute a total load of $50 \%$ of capacity, across both legs of the fuel cell power plant output, if applicable.

2. Set Grid Simulator to have a starting point voltage equal to the grid independent output voltage of the fuel cell power plant.

3. The time spent at each step shall be one minute.

4. Increase the Grid Simulator output voltage by 1vac and remain at each new voltage value for one minute.

5. Increase the Grid Simulator output voltage until the output is $20 \%$ higher than the starting voltage of $120 \mathrm{VAC}$ per leg, the fuel cell power plant goes grid independent, or the fuel cell power plant shuts down.

6. Reset the Grid Simulator starting voltage and, if necessary, restart the fuel cell power plant.

7. Decrease the Grid Simulator output voltage by 1vac and remain at each new voltage for one minute.

8. Decrease the Grid simulator output voltage until the fuel cell power plant switches from grid connect to grid independent or the fuel cell power plant shuts down. 
9. Reset the Grid Simulator to the starting voltage and, if necessary, restart the fuel cell power plant.

10. Repeat Voltage Sag/Surge Test three times to obtain a pattern of repeatability.

\section{Test 3-Neutral Loss Test}

1. Equally distribute a total load of $50 \%$ of capacity, across both legs of the fuel cell power plant output, if applicable.

2. The Grid Simulator should be set to grid normal operating mode.

3. Initial load bank values will be equal and total $50 \%$ of the fuel cell power plants output capabilities. One of the loads shall vary according to the test table.

4. For each set of load values, the neutral shall start in a closed condition, then in the next step open for one minute.

5. The state of the power plant shall be recorded, and if the fuel cell power plant switches from grid connect to grid independent, or shuts down the test shall be considered finished.

6. Repeat Neutral Loss Test three times to obtain a pattern of repeatability.

\section{Test 4-Waveform Distortion/Harmonic Distortion Test}

1. Equally distribute a total load of $50 \%$ across both legs of the fuel cell power plant output if 240 VAC outlet, if applicable.

2. Run program in Grid Simulator that will create the following increments of harmonic distortion for 1 minute. $5 \%, 10 \%, 12.6 \%$ and $14.4 \%$.

3. Allow fuel cell to recover between increments of harmonic distortion.

4. Repeat test three times for proof of repeatability.

\section{Test 5-Disconnect Speed Test}

This test will be the time duration between grid connect and grid independent when one of the following disturbances occurs: Frequency deviation, voltage sag/surge, waveform/harmonic distortion, loss of one voltage leg, loss of both voltage legs, and neutral loss.

5. Equally distribute a total load of $50 \%$ across both legs of the fuel cell power plant output if 240 VAC outlet, if applicable.

6. Using the CDAQ record grid side and load side parameters.

7. Create disturbance that will cause the FCPP to go into Grid Independent mode.

8. Record and graph data showing grid side and load side parameters vs. time. 


\section{Data Acquisition Parameters}

Table S1. Power grid simulation test, data acquisition parameters.

\begin{tabular}{|l|l|l|}
\hline $\begin{array}{l}\text { Electrical Information from } \\
\text { CTC Sensors. }\end{array}$ & $\begin{array}{l}\text { Fuel Supply Rate } \\
\text { from CTC Sensor }\end{array}$ & $\begin{array}{l}\text { Environmental Information } \\
\text { from CTC Sensors }\end{array}$ \\
\hline Sampling Rate 10 per second & $\begin{array}{l}\text { Sampling Rate 10 per sec- } \\
\text { ond }\end{array}$ & Sampling Rate 10 per second \\
\hline Gross Output, Stack Current & Inlet Fuel Mass Flow & Air Discharge Rate \\
\hline Net Output Current (AC or DC) & & Air Discharge Temperature \\
\hline Output Voltage (AC or DC) & & Ambient Air Temperature \\
\hline State of Neutral & & Fuel Cell Stack Temperature \\
\hline
\end{tabular}

Table S2. Power grid simulation test, grid simulator feedback data to be recorded.

\begin{tabular}{|l|l|l|}
\hline $\begin{array}{l}\text { Frequency Deviation Value } \\
\text { State of Neutral }\end{array}$ & $\begin{array}{l}\text { Voltage Sag Percentage \% of } \\
\text { THD }\end{array}$ & $\begin{array}{l}\text { Voltage Surge Percentage } \\
\text { Disconnect Speed (time) }\end{array}$ \\
\hline $\begin{array}{l}\text { All data collected by the FCPP on } \\
\text { board Data Acquisition System }\end{array}$ & & \\
\hline
\end{tabular}

Table S3. Power grid simulation test, frequency deviation test.

\begin{tabular}{|c|c|c|c|c|}
\hline $\begin{array}{c}\text { Test } \\
\#\end{array}$ & $\begin{array}{c}\text { Total Test } \\
\text { Time Minutes }\end{array}$ & $\begin{array}{l}2 \text { Equal Electronic } \\
\text { Loads (Watts) } \\
50 \% \text { of usable output }\end{array}$ & $\begin{array}{c}\text { Grid Simulator } \\
\text { Frequency } \\
(60 \mathrm{HZ})\end{array}$ & $\begin{array}{l}\text { Power Plant Status } \\
\text { Grid Connect/Grid } \\
\text { Independent/Shut Down }\end{array}$ \\
\hline 1 & $1 \mathrm{~min}$ & $50 \%$ of Capacity & $\begin{array}{l}\text { Initial Value Equal to } \\
\text { Power Grid Frequency }\end{array}$ & \\
\hline 2 & $2 \min$ & $50 \%$ of capacity & Power Grid freq. $+.01 \mathrm{~Hz}$ & \\
\hline 3 & $3 \min$ & $50 \%$ of capacity & Power Grid freq. $+.02 \mathrm{~Hz}$ & \\
\hline 4 & $4 \min$ & $50 \%$ of capacity & Power Grid freq. $+.03 \mathrm{~Hz}$ & \\
\hline 5 & $5 \min$ & $50 \%$ of capacity & Power Grid freq. $+.04 \mathrm{~Hz}$ & \\
\hline 6 & $6 \min$ & $50 \%$ of capacity & Power Grid freq. $+.05 \mathrm{~Hz}$ & \\
\hline 7 & $7 \mathrm{~min}$ & $50 \%$ of capacity & Power Grid freq. $+.06 \mathrm{~Hz}$ & \\
\hline 8 & $8 \min$ & $50 \%$ of capacity & Power Grid freq. $+.07 \mathrm{~Hz}$ & \\
\hline 9 & $9 \min$ & $50 \%$ of capacity & Power Grid freq. $+.08 \mathrm{~Hz}$ & \\
\hline 10 & $10 \min$ & $50 \%$ of capacity & Power Grid freq. + .09 Hz & \\
\hline 11 & $11 \mathrm{~min}$ & $50 \%$ of capacity & $\begin{array}{l}\text { Continue Increments until } \\
\text { Power Plant Disconnect }\end{array}$ & \\
\hline 12 & $12 \min$ & $50 \%$ of capacity & Power Grid Frequency & \\
\hline 13 & $13 \min$ & $50 \%$ of capacity & Power Grid freq. $-.01 \mathrm{~Hz}$ & \\
\hline 14 & $14 \min$ & $50 \%$ of capacity & Power Grid freq. $-.02 \mathrm{~Hz}$ & \\
\hline 16 & $16 \min$ & $50 \%$ of capacity & Power Grid freq. $-.03 \mathrm{~Hz}$ & \\
\hline 17 & $17 \min$ & $50 \%$ of capacity & Power Grid freq. $-.04 \mathrm{~Hz}$ & \\
\hline 18 & $18 \min$ & $50 \%$ of capacity & Power Grid freq. $-.05 \mathrm{~Hz}$ & \\
\hline 19 & $19 \min$ & $50 \%$ of capacity & Power Grid freq. $-.06 \mathrm{~Hz}$ & \\
\hline 20 & $20 \min$ & $50 \%$ of capacity & Power Grid freq. $-.07 \mathrm{~Hz}$ & \\
\hline 21 & $21 \min$ & $50 \%$ of capacity & Power Grid freq. $-.08 \mathrm{~Hz}$ & \\
\hline 22 & $22 \min$ & $50 \%$ of capacity & Power Grid freq. $-.09 \mathrm{~Hz}$ & \\
\hline
\end{tabular}




\begin{tabular}{|l|l|l|l|l|}
\hline $\begin{array}{c}\text { Test } \\
\#\end{array}$ & $\begin{array}{c}\text { Total Test } \\
\text { Time Minutes }\end{array}$ & $\begin{array}{c}\text { 2 Equal Electronic } \\
\text { Loads (Watts) } \\
\mathbf{5 0 \%} \text { of usable output }\end{array}$ & $\begin{array}{c}\text { Grid Simulator } \\
\text { Frequency } \\
(\mathbf{6 0 H Z})\end{array}$ & $\begin{array}{c}\text { Power Plant Status } \\
\text { Grid Connect/Grid } \\
\text { Independent/Shut Down }\end{array}$ \\
\hline 23 & $23 \mathrm{~min}$ & $50 \%$ of capacity & Power Grid freq. $-0.10 \mathrm{~Hz}$ & \\
\hline $24+$ & $24 \mathrm{~min}$ & $50 \%$ of capacity & $\begin{array}{l}\text { Continue Increments until } \\
\text { Power Plant Disconnect }\end{array}$ & \\
\hline
\end{tabular}

Table S4. Power grid simulation test, voltage surge/sag test.

\begin{tabular}{|c|c|c|c|c|}
\hline Test \# & $\begin{array}{l}\text { Total Test } \\
\text { Time } \\
\text { Minutes } \\
\end{array}$ & $\begin{array}{l}2 \text { Equal Electronic } \\
\text { Loads (Watts) } \\
50 \% \text { of usable output }\end{array}$ & $\begin{array}{l}\text { Grid Simulator Output } \\
\text { Voltage }\end{array}$ & $\begin{array}{l}\text { Power plant Status } \\
\text { Grid Connect/Grid } \\
\text { Independent/Shutdown }\end{array}$ \\
\hline 1 & $1 \mathrm{~min}$ & $50 \%$ of capacity & Normal Output Voltage & \\
\hline 2 & $2 \min$ & $50 \%$ of capacity & $\mathrm{NOV}+1 \mathrm{vac}$ & \\
\hline 3 & $3 \mathrm{~min}$ & $50 \%$ of capacity & $\mathrm{NOV}+2 \mathrm{vac}$ & \\
\hline 4 & $4 \min$ & $50 \%$ of capacity & $\mathrm{NOV}+3 \mathrm{vac}$ & \\
\hline 5 & $5 \mathrm{~min}$ & $50 \%$ of capacity & $\mathrm{NOV}+4 \mathrm{vac}$ & \\
\hline 6 & $6 \mathrm{~min}$ & $50 \%$ of capacity & $\mathrm{NOV}+5 \mathrm{vac}$ & \\
\hline 7 & $7 \mathrm{~min}$ & $50 \%$ of capacity & $\mathrm{NOV}+6 \mathrm{vac}$ & \\
\hline 8 & $8 \mathrm{~min}$ & $50 \%$ of capacity & $\mathrm{NOV}+7 \mathrm{vac}$ & \\
\hline 9 & $9 \min$ & $50 \%$ of capacity & $\mathrm{NOV}+8 \mathrm{vac}$ & \\
\hline 10 & $10 \min$ & $50 \%$ of capacity & $\mathrm{NOV}+9 \mathrm{vac}$ & \\
\hline 11 & $11 \mathrm{~min}$ & $50 \%$ of capacity & $\mathrm{NOV}+10 \mathrm{vac}$ & \\
\hline 12 & $12 \min$ & $50 \%$ of capacity & $\mathrm{NOV}+11 \mathrm{vac}$ & \\
\hline $13+$ & $13 \min$ & $50 \%$ of capacity & $\begin{array}{l}\text { Continue Increments until } \\
\text { Power Plant Disconnect }\end{array}$ & \\
\hline 14 & $14 \min$ & $50 \%$ of capacity & Normal Output Voltage & \\
\hline 15 & $15 \min$ & $50 \%$ of capacity & NOV - 1vac & \\
\hline 16 & $16 \min$ & $50 \%$ of capacity & NOV - 2vac & \\
\hline 17 & $17 \min$ & $50 \%$ of capacity & NOV - 3vac & \\
\hline 18 & $18 \mathrm{~min}$ & $50 \%$ of capacity & NOV - 4vac & \\
\hline 19 & $19 \min$ & $50 \%$ of capacity & NOV - 5vac & \\
\hline 20 & $20 \min$ & $50 \%$ of capacity & NOV - 6vac & \\
\hline 21 & $21 \min$ & $50 \%$ of capacity & NOV - 7vac & \\
\hline 22 & $22 \min$ & $50 \%$ of capacity & NOV - 8vac & \\
\hline 23 & $23 \min$ & $50 \%$ of capacity & NOV - 9vac & \\
\hline 24 & $24 \min$ & $50 \%$ of capacity & NOV - 10vac & \\
\hline 25 & $25 \min$ & $50 \%$ of capacity & NOV - 11vac & \\
\hline 26 & $26 \min$ & $50 \%$ of capacity & NOV - 12vac & \\
\hline $27+$ & $27 \min$ & $50 \%$ of capacity & $\begin{array}{l}\text { Continue Increments until } \\
\text { Power Plant Disconnect }\end{array}$ & \\
\hline
\end{tabular}


Table S5. Power grid simulation test, neutral loss test.

\begin{tabular}{|c|c|c|c|c|c|c|c|}
\hline Test \# & $\begin{array}{l}\text { State of } \\
\text { Neutral }\end{array}$ & $\begin{array}{c}\text { Neutral } \\
\text { Open } \\
\text { Time } \\
\end{array}$ & $\begin{array}{l}\text { Neural } \\
\text { Closed } \\
\text { Time } \\
\text { Seconds }\end{array}$ & $\begin{array}{c}\text { Total Time } \\
\text { Minutes/ } \\
\text { Seconds }\end{array}$ & $\begin{array}{c}\text { Load Bank } \\
1 \text { Watts }\end{array}$ & $\begin{array}{c}\text { Load Bank } \\
2 \text { Watts }\end{array}$ & $\begin{array}{l}\text { Power Plant } \\
\text { Status } \\
\text { Grid } \\
\text { Connect/ } \\
\text { Grid } \\
\text { Independent/ } \\
\text { Shutdown } \\
\end{array}$ \\
\hline 1 & Closed & & 15 & :15 & 1500 & 1500 & \\
\hline 2 & Open & 60 & & $1: 15$ & 1500 & 1500 & \\
\hline 3 & Closed & & 15 & $1: 30$ & 1500 & 1400 & \\
\hline 4 & Open & 60 & & $2: 30$ & 1500 & 1400 & \\
\hline 5 & Closed & & 15 & $2: 45$ & 1500 & 1300 & \\
\hline 6 & Open & 60 & & $3: 45$ & 1500 & 1300 & \\
\hline 7 & Closed & & 15 & 4:00 & 1500 & 1200 & \\
\hline 8 & Open & 60 & & $5: 00$ & 1500 & 1200 & \\
\hline 9 & Closed & & 15 & $5: 15$ & 1500 & 1100 & \\
\hline 10 & Open & 60 & & 6:15 & 1500 & 1100 & \\
\hline 11 & Closed & & 15 & $6: 30$ & 1500 & 1000 & \\
\hline 12 & Open & 60 & & $7: 30$ & 1500 & 1000 & \\
\hline 13 & Closed & & 15 & $7: 45$ & 1500 & 900 & \\
\hline 14 & Open & 60 & & $8: 45$ & 1500 & 900 & \\
\hline 15 & Closed & & 15 & 9:00 & 1500 & 800 & \\
\hline 16 & Open & 60 & & 10:00 & 1500 & 800 & \\
\hline 17 & Closed & & 15 & 10:15 & 1500 & 700 & \\
\hline 18 & Open & 60 & & $11: 15$ & 1500 & 700 & \\
\hline 19 & Closed & & 15 & $11: 30$ & 1500 & 600 & \\
\hline 20 & Open & 60 & & $12: 30$ & 1500 & 600 & \\
\hline 21 & Closed & & 15 & $12: 45$ & 1500 & 500 & \\
\hline 22 & Open & 60 & & $13: 45$ & 1500 & 500 & \\
\hline 23 & Closed & & 15 & $14: 00$ & 1500 & 400 & \\
\hline 24 & Open & 60 & & $15: 00$ & 1500 & 400 & \\
\hline 25 & Closed & & 15 & $15: 15$ & 1500 & 300 & \\
\hline 26 & Open & 60 & & $16: 15$ & 1500 & 300 & \\
\hline 27 & Closed & & 15 & $16: 30$ & 1500 & 200 & \\
\hline 28 & Open & 60 & & $17: 30$ & 1500 & 200 & \\
\hline 29 & Closed & & 15 & $17: 45$ & 1500 & 100 & \\
\hline 30 & Open & 60 & & $18: 45$ & 1500 & 100 & \\
\hline 31 & Closed & & 15 & 19:00 & 1500 & 0 & \\
\hline 32 & Open & 60 & & 20:00 & 1500 & 0 & \\
\hline 33 & Closed & & & & 1500 & 1500 & \\
\hline
\end{tabular}




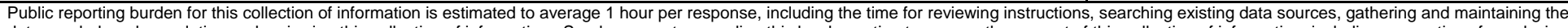

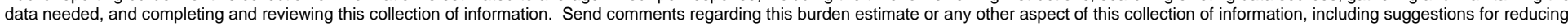

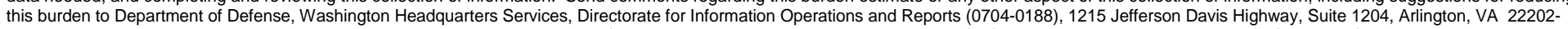

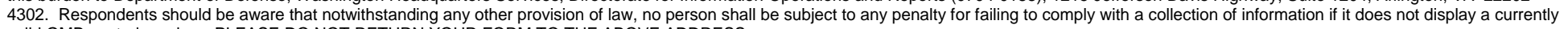
valid OMB control number. PLEASE DO NOT RETURN YOUR FORM TO THE ABOVE ADDRESS.
1. REPORT DATE (DD-MM-YYYY) 10-2004

\section{REPORT TYPE}
Final

\section{TITLE AND SUBTITLE}

Phosphoric Acid Fuel Cells:

Test and Evaluation

3. DATES COVERED (From - To)

5a. CONTRACT NUMBER

5b. GRANT NUMBER

5c. PROGRAM ELEMENT NUMBER

5d. PROJECT NUMBER

MIPR

5e. TASK NUMBER

5f. WORK UNIT NUMBER

006G7B

8. PERFORMING ORGANIZATION REPORT NUMBER

ERDC/CERL TR-04-21

Construction Engineering Research Laboratory (CERL)

PO Box 9005

Champaign, IL 61826-9005

\section{SPONSORING I MONITORING AGENCY NAME(S) AND ADDRESS(ES)}

Office of Director, Defense, Research, and Engineering (ODDR\&E)

10. SPONSOR/MONITOR'S ACRONYM(S)

ODDR\&E

1777 N. Kent

Suite 9030

Rosslyn, VA 22209

11. SPONSOR/MONITOR'S REPORT NUMBER(S)

\section{DISTRIBUTION I AVAILABILITY STATEMENT}

Approved for public release; distribution is unlimited.

\section{SUPPLEMENTARY NOTES}

Copies are available from the National Technical Information Service, 5285 Port Royal Road, Springfield, VA 22161.

\section{ABSTRACT}

Fuel cell power plants can provide improvements in energy conservation and reduced environmental impacts for many DOD applications. Currently, the U.S. Army Engineer Research and Development Center, Construction Engineering Research Laboratory (ERDC/CERL) Fuel Cell Technology Program facilitates the development of Fuel Cell Technology. This work provided testing and evaluations of fuel cells in support of life-cycle-cost reduction and performance improvement goals. This program also undertook to provide the capability for independent design assessments of alternative technology fuel cell system configurations and components to achieve lower life cycle cost either through reduced capital cost, reduced operation and maintenance (O\&M) costs, or increased performance and reliability.

\section{SUBJECT TERMS}

fuel cells energy conservation energy efficient lifecycle costs

\begin{tabular}{|c|c|c|c|c|}
\hline \multicolumn{3}{|c|}{ 16. SECURITY CLASSIFICATION OF: } & \multirow{2}{*}{$\begin{array}{l}\text { 17. LIMITATION } \\
\text { OF ABSTRACT } \\
\text { SAR }\end{array}$} & \multirow{2}{*}{$\begin{array}{l}\text { 18. NUMBER } \\
\text { OF PAGES } \\
184\end{array}$} \\
\hline $\begin{array}{l}\text { a. REPORT } \\
\text { Unclassified }\end{array}$ & $\begin{array}{l}\text { b. ABSTRACT } \\
\text { Unclassified }\end{array}$ & $\begin{array}{l}\text { c. THIS PAGE } \\
\text { Unclassified }\end{array}$ & & \\
\hline
\end{tabular}

power plants

Franklin H. Holcomb
19b. TELEPHONE NUMBER (in-
clude area code)
(217) 373-5864

